\title{
Hydrology and Water Quality of Unmined and Reclaimed Basins in Phosphate-Mining Areas, West-Central Florida
}

\author{
By B.R. Lewelling and R.W. Wylie
}

U.S. GEOLOGICAL SURVEY

Water-Resources Investigations Report 93-4002

Prepared in cooperation with the

FLORIDA INSTITUTE OF PHOSPHATE RESEARCH 


\section{U.S. DEPARTMENT OF THE INTERIOR \\ BRUCE BABBITT, Secretary}

U.S. GEOLOGICAL SURVEY

DALLAS L. PECK, Director

Any use of trade, product, or firm names in this publication is for descriptive purposes only and does not imply endorsement by the U.S. Geological Survey.

For additional information write to:

\section{District Chief}

U.S. Geological Survey

Suite 3015

227 N. Bronough Street

Tallahassee, FL 32301
Copies of this report can be purchased from:

U.S. Geological Survey Books and Open-File Reports Section Federal Center Box 25425

Denver, CO 80225 


\section{CONTENTS}

Abstract 1

Introduction 1

Purpose and scope $\mathbf{3}$

Previous investigations $\mathbf{3}$

Acknowledgments $\mathbf{3}$

Description of the study area $\mathbf{3}$

Physiography and soils 4

Climate 6

Surface drainage 7

Hydrogeologic framework 7

Surficial aquifer system 7

Intermediate aquifer system 9

Upper Floridan aquifer $\mathbf{1 1}$

Description of mining techniques $\mathbf{1 1}$

Reclamation methods 12

Methods of study 12

Description and hydrologic setting of unmined basins

IMC Creek 13

Grace Creek 17

CFI-3 Creek 21

Description and hydrologic setting of reclaimed basins

Mobil Creek 25

Agrico-9 Creek 28

CFI-1 Creek 31

Agrico-4 Creek 34

Agrico-1 Creek 35

Effects of land reclamation on hydrogeology

Surficial aquifer system $\mathbf{4 1}$

Intermediate aquifer system $\mathbf{4 5}$

Effects of land reclamation on streamflow

49

Daily mean discharge $\mathbf{5 1}$

Discharge duration $\mathbf{5 1}$

Maximum peak discharges $\mathbf{5 5}$

Rainfall-runoff relations 56

Water-quality 67

Water in the surficial aquifer system $\mathbf{6 7}$

Nitrogen and phosphorus 69

Major constituents 69

Trace elements $\mathbf{7 9}$

Radiochemicals $\mathbf{8 0}$

Water in the intermediate aquifer system $\mathbf{8 0}$

Surface water $\mathbf{8 0}$

Nitrogen and phosphorus $\mathbf{8 3}$

Major constituents $\mathbf{8 3}$

Trace elements $\mathbf{8 8}$

- Radiochemicals 89

Summary and conclusions $\mathbf{9 0}$

Selected references $\mathbf{9 1}$ 
Figure

1-4. Maps showing:

1. Study area, locations of generalized hydrogeologic sections, and extent of mineable phosphate deposits in west-central Florida 2

2. Locations of basins and ROMP well $48 \quad 4$

3. Location of phosphate-mined area, area permitted for future mining, and unpermitted area owned by phosphate companies 5

4. Physiography of the study area 6

5. Graph showing monthly rainfall, $1988-90$, and mean monthly rainfall at Wauchula, Fla. 7

6. Hydrogeologic sections A-A' and B-B' 8

7. Maps showing potentiometric surface of the intermediate aquifer system, May and September $1988 \quad 11$

8. Map showing location of IMC Creek basin, topography, and data-collection network 14

9. Graphs showing daily rainfall and ground-water levels in monitor wells at the IMC Creek basin, June 1988 to October 199015

10. Maps showing configuration of the water table in the surficial aquifer system at the IMC Creek basin, June and October $1989 \quad 15$

11. Graphs showing water levels based on periodic measurements in wells completed in the surficial aquifer system, IMC Creek basin, June 1988 to October 199016

12. Hydrogeologic units, lithology, natural gamma-ray log, and stratigraphic units at well IMC-DP, completed in the intermediate aquifer system at the IMC Creek basin 17

13. Map showing location of the Grace Creek basin, topography, and data-collection network 18

14. Graphs showing daily rainfall and ground-water levels in monitor wells at the Grace Creek basin, June 1988 to October 199019

15. Maps showing configuration of the water table in the surficial aquifer system at the Grace Creek basin, June and October 198919

16. Graphs showing water levels based on periodic measurements in wells completed in the surficial aquifer system, Grace Creek basin, September 1988 to October $1990 \quad 20$

17. Hydrogeologic units, lithology, natural gamma-ray log, and stratigraphic units at well Grace-DP, completed in the intermediate aquifer system at the Grace Creek basin 21

18. Map showing location of CFI-3 Creek basin, topography, and data-collection network 22

19. Graphs showing daily rainfall and ground-water levels in monitor wells at the CFI-3 Creek basin, February 1989 to October 199023

20. Maps showing configuration of the water table of the surficial aquifer system at the CFI-3 Creek basin, June and October 198923

21. Graphs showing water levels based on periodic measurements in wells completed in the surficial aquifer system, CFI-3 Creek basin, September 1988 to October $1990 \quad 24$ 
22. Hydrogeologic units, lithology, natural gamma-ray log, and stratigraphic units at well CFI3-DP, completed in the intermediate aquifer system at the CFI-3 Creek basin 25

23. Map showing location of the Mobil Creek basin, topography, and data-collection network 26

24. Hydrogeologic units, lithology, natural gamma-ray log, and stratigraphic units at well MBL-DP, completed in the intermediate aquifer system at the Mobil Creek basin 27

25. Graphs showing daily rainfall and ground-water levels in monitor wells at Mobil Creek basin, February 1989 to October 199027

26. Maps showing configuration of the water table in the surficial aquifer system at the Mobil Creek basin, June and October 198928

27. Graphs showing water levels based on periodic measurements in wells completed in the surficial aquifer system at the Mobil Creek basin, September 1988 to October $1990 \quad 29$

28. Map showing location of Agrico-9 Creek basin, topography, data-collection network, and line of hydrogeologic section $\mathrm{C}^{-\mathrm{C}^{\prime}} \quad \mathbf{3 0}$

29. Hydrogeologic section $C_{-} C^{\prime}$ at Agrico-9 Creek clay-settling basin 32

30. Hydrogeologic units, lithology, natural gamma-ray log, and stratigraphic units at well AG9-DP, completed in the intermediate aquifer system at the Agrico-9 Creek basin 33

31. Graphs showing daily rainfall and ground-water levels in monitor wells at Agrico-9 Creek basin, June 1988 to October $1990 \quad 34$

32. Maps showing the configuration of the water table in the surficial aquifer system at Agrico-9 Creek basin, June and August 198935

33. Graphs showing water levels based on periodic measurements in wells completed in the surficial aquifer system at Agrico-9 Creek basin, September 1988 to October $1990 \quad 36$

34. Map showing location of CFI-1 Creek basin, topography, data-collection network, and line of hydrogeologic section ${\mathrm{D}-\mathrm{D}^{\prime}}^{\prime} 37$

35. Hydrogeologic section D-D' at CFI-1 Creek sand-clay settling basin $\mathbf{3 8}$

36. Hydrogeologic units, lithology, natural gamma-ray log, and stratigraphic units at well CFI1-DP, completed in the intermediate aquifer system at the CFI-1 Creek basin 39

37. Graphs showing daily rainfall and ground-water levels in monitor wells at the CFI-1 Creek basin, June 1988 to October $1990 \quad 40$

38. Maps showing configuration of the water table in the surficial aquifer system at the CFI-1 Creek basin, June and August 198941

39. Graphs showing water levels based on periodic measurements in wells completed in the surficial aquifer system at the CFI-1 Creek basin, June 1988 to October $1990 \mathbf{4 2}$

40. Map showing location of Agrico-4 Creek basin, topography, data-collection network, and line of hydrogeologic section $E-E^{\prime} \quad \mathbf{4 3}$

41. Hydrogeologic section E-E' at Agrico-4 Creek overburden-capped sand-tailings basin 
42. Hydrogeologic units, lithology, natural gamma-ray log, and stratigraphic units at well AG4-DP, completed in the intermediate aquifer system at the Agrico-4 Creek basin 45

43. Graphs showing daily rainfall and ground-water levels in monitor wells at Agrico-4 Creek basin, June 1988 to October 199046

44. Maps showing configuration of the water table in the surficial aquifer system at Agrico-4 Creek basin, June and October 198946

45. Graphs showing water levels based on periodic measurements in wells completed in the surficial aquifer system at the Agrico-4 Creek basin, June 1988 to October 199047

46. Map showing location of Agrico-1 Creek basin, topography, data-collection network, and line of hydrogeologic section $\mathrm{F}-\mathrm{F}^{\prime} \quad \mathbf{4 8}$

47. Hydrogeologic section F-F' at Agrico-1 Creek contoured-overburden basin

48. Hydrogeologic units, lithology, natural gramma-ray logs, and stratigraphic units at well AG1-DP, completed in the intermediate aquifer system at the Agrico-1 Creek basin $\mathbf{5 0}$

49. Graphs showing daily rainfall and ground-water levels in monitor wells at Agrico-1 Creek basin, June 1988 to October $1990 \quad \mathbf{5 0}$

50. Maps showing configuration of the water table in the surficial aquifer system at the Agrico-1 Creek basin, June and August $1989 \quad 51$

51-58. Graphs showing:

51. Water levels based on periodic measurements in wells completed in the surficial aquifer system at the Agrico-1 Creek basin, June 1988 to October $1990 \mathbf{5 2}$

52. Water levels in monitor wells completed in the surficial aquifer system at the eight study basins, June 1988 to October $1990 \mathbf{5 3}$

53. Water levels in monitor wells completed in the intermediate aquifer system at the eight study basins, June 1988 to October $1990 \quad 54$

54. Daily rainfall and daily mean discharge, June 1988 to September 1990, at the eight study basins $\mathbf{5 5}$

55. Duration curves of daily mean discharge at six study basins, 1988-90 $\mathbf{5 9}$

56. Monthly rainfall and runoff at six study basins, September 1988 through September $1990 \quad 61$

57. Discharge and rainfall during typical thunderstorms, 1988-90 63

58. Discharge and rainfall during typical frontal storms, 1988-90 $\mathbf{6 8}$

59. Boxplots showing distribution of values and concentrations of selected properties and constituents in water from the surficial aquifer system at study basins in unmined and reclaimed areas $\mathbf{7 8}$

60. Trilinear diagram showing chemical composition of water from the surficial aquifer system in the eight study basins 79

61. Boxplots showing distribution of values and concentrations of selected properties and constituents in water from the intermediate aquifer system at study basins in unmined and reclaimed areas $\mathbf{8 1}$

62. Boxplots showing distribution of values and concentrations of selected properties and constituents in water from streams in study basins at unmined and reclaimed areas 86

63. Trilinear diagram showing chemical composition of water from streams in the study basin $\mathbf{8 9}$ 
Table

1. Geologic and hydrogeologic units in the study area

2. Summary of aquifer test results $\mathbf{1 0}$

3. Extremes of daily mean discharge at the eight study basins $\mathbf{6 0}$

4. Peak discharge, rainfall, and runoff during typical thunderstorms in the west-central Florida phosphate-mining region, 1988-90 62

5. Peak discharge, rainfall, and runoff during typical frontal storms in the west-central Florida phosphate-mining region, 1988-90 73

6. Physical and chemical characteristics of water from the surficial aquifer system at the eight study basins--reconnaissance samples $\mathbf{7 4}$

7. Physical and chemical characteristics of water from the surficial aquifer system at the eight study basins--bimonthly samples $\mathbf{7 5}$

8. Physical and chemical characteristics of water from the intermediate aquifer system at six study basins--bimonthly samples $\mathbf{8 2}$

9. Physical and chemical characteristics of water from streams in the study basins--reconnaissance samples 84

10. Physical and chemical characteristics of water from streams in the study basins--bimonthly samples

87 
Conversion Factors, Vertical Datum, Abbreviated Water-Quality Units, and Acronyms

\begin{tabular}{lcl}
\hline \multicolumn{1}{c}{ Multiply } & By & \multicolumn{1}{c}{ To obtain } \\
\hline inch (in.) & 25.4 & millimeter \\
foot (ft) & 0.3048 & meter \\
foot per day $(\mathrm{ft} / \mathrm{d})$ & 0.3048 & meter per day \\
mile (mi) & 1.609 & kilometer \\
foot squared per day $\left(\mathrm{ft}^{2} / \mathrm{d}\right)$ & 0.0929 & meter squared per day \\
gallon per minute $(\mathrm{gal} / \mathrm{min})$ & 0.06308 & liter per second \\
square mi $\left(\mathrm{mi}^{2}\right)$ & 2.590 & square kilometer \\
acre & 4047 & square meter \\
cubic foot per second $\left(\mathrm{ft}^{3} / \mathrm{s}\right)$ & 0.02832 & cubic meter per second \\
cubic foot per second & 0.01093 & cubic meter per second \\
per square mile $\left[\left(\mathrm{ft}^{3} / \mathrm{s}\right) / \mathrm{mi}^{2}\right]$ & & per square kilometer
\end{tabular}

Temperature is given in degrees Celsius $\left({ }^{\circ} \mathrm{C}\right)$ or degrees Fahrenheit $\left({ }^{\circ} \mathrm{F}\right)$, which can be converted by the following equations:

$$
\begin{aligned}
& { }^{\circ} \mathrm{C}=\left(5 / 9\left({ }^{\circ} \mathrm{F}-32\right)\right. \\
& { }^{\circ} \mathrm{F}=\left(9 / 5{ }^{\circ} \mathrm{C}\right)+32
\end{aligned}
$$

Sea level: In this report, "sea level" refers to the National Geodetic Vertical Datum of 1929 (NGVD of 1929)--a geodetic datum derived from a general adjustment of the first-order level nets of the United States and Canada, formerly called Sea Level Datum of 1929.

Abbreviated water-quality units

$\mu \mathrm{g} / \mathrm{L}$ micrograms per liter

$\mu \mathrm{S} / \mathrm{cm}$ microsiemens per centimeter at 25 degrees Celsius

$\mathrm{mg} / \mathrm{L}$ milligrams per liter

$\mathrm{pCi} / \mathrm{L}$ picocuries per liter

Pt-Co platinum-cobalt

\section{Acronyms}

FDER Florida Department of Environmental Regulation

FIPR Florida Institute of Phosphate Research

GPS global positioning system

PVC polyvinylchloride

USGS U.S. Geological Survey 


\title{
Hydrology and Water Quality of Unmined and Reclaimed Basins in Phosphate-Mining Areas, West-Central Florida
}

\author{
By B.R. Lewelling and R.W. Wylie
}

\section{ABSTRACT}

The effects of reclamation of phosphate-mined lands on the hydrology and water quality of surface- and groundwater resources in west-central Florida was the subject of a study conducted during 1988-90. The background hydrologic characteristics and water quality of three small unmined basins in the area were compared to those of five reclaimed phosphate-mined basins that represented four unique reclamation methods.

A data-collection network was established in each basin to monitor streamflow, rainfall, and water levels in the surficial and intermediate aquifer systems. Water samples from 14 wells and 5 streams were analyzed for chemical constituents, including major ions, nutrients, trace elements, and radiochemicals.

The hydrologic effects of reclamation vary with the type of fill material used during reclamation. Reclamation commonly involves backfilling mined areas with either clay, sand-tailings, or both, as well as overburden displaced during mining. The clay and sand-tailings are separated from the phosphate matrix (phosphate, sand, and clay) during ore processing. Peak runoff rates from the reclaimed basins generally were higher than those from the unmined basins during intense, short-duration thunderstorms; however, peak runoff rates during low-intensity, long-duration frontal storms were similar at all basins. Runoff responds more slowly to rainfall in the reclaimed basins than in the unmined basins because of undeveloped drainage systems in the reclaimed basins. Based on streamflow records collected during this study, no flow occurred about 31 percent of the time at sites on streams in the unmined basins and from 16 to 90 percent of the time at sites on streams in the reclaimed basins.

In three reclaimed basins backfilled with clay, there was no sustained base flow to streams, and runoff rates were relatively small because of surface storage in depressions in the land surface. The depth to the water table in the surficial aquifer in these three reclaimed basins generally was much greater than that in the unmined basins and in the reclaimed basins backfilled with overburden, and recharge from the surficial aquifer to the underlying intermediate aquifer system was greatly reduced.

In the reclaimed basins backfilled with overburden, streamflows were characterized by relatively low peak runoff rates but relatively high base flows. The fluctuations in water levels and depths to the water table in these reclaimed basins were similar to those in the unmined basins, and recharge from the surficial aquifer to the underlying intermediate aquifer system was greater than in the reclaimed basins backfilled with clay. Also, the hydraulic head difference between the two aquifer systems was smaller in the reclaimed basins backfilled with overburden and in the unmined basins than in the basins backfilled with clay.

Results of analyses of water samples from the surficial aquifer system indicated higher concentrations of most constituents in water from the reclaimed basins than in water from the unmined basins. Concentrations of dissolved solids, iron, sulfate, manganese, and lead exceeded regulatory standards at various reclaimed basins; however, iron concentrations and gross-alpha activities were the only constituents to exceed Florida Department of Environmental Regulation standards at the unmined basins. Radiochemical analyses of water from the surficial aquifer system at two unmined basins indicated gross-alpha activities of 53.0 and 37.4 picocuries per liter, much greater than the gross-alpha activities of 1.90 to 5.24 picocuries per liter from the reclaimed basins. The higher activities at the unmined basins are attributed to phosphate-ore deposits in the area around the sampled wells. Radiochemical analyses of water from streams during base-flow and highflow conditions indicate that the water chemistry of the unmined and the reclaimed basins are similar. Uranium234 activity was 4.3 picocuries per liter in water from a stream in a basin backfilled with clay, but activities were less than 0.8 picocuries per liter in water from streams in the remaining seven study basins. Reclaimed basins backfilled with clay commonly are rich in radiochemical constituents associated with phosphate ore, and streams draining these basins sometimes contain water with elevated concentrations of these constituents.

\section{INTRODUCTION}

The open-pit mining of near-surface phosphate deposits has affected the hydrology of a 2,000- $\mathrm{mi}^{2}$ area in west-central Florida (fig. 1). Currently (1992), mining and chemical companies own about 450,000 acres, or about 35 percent of the land within this area. Much of this land might be mined before the year 2000. Open-pit mining involves dewatering 


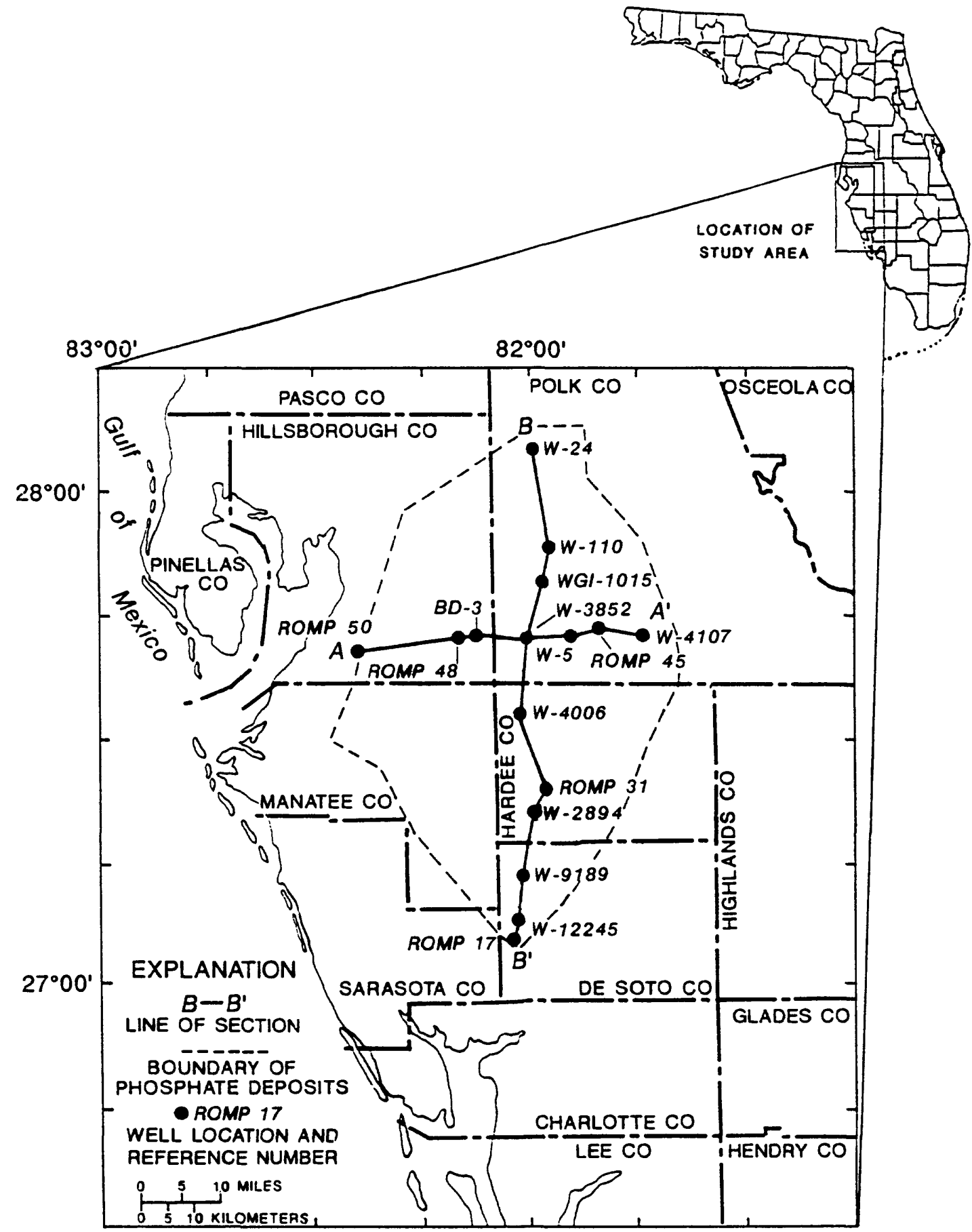

Figure 1. Study area, locations of generalized hydrogeologic sections, and extent of mineable phosphate deposits in west-central Florida. (Modified from Long and Orne, 1990.) 
the overburden, setting aside the overburden, and stripping of the phosphate matrix. Consequently, the topography and the natural drainage system are altered during the mining process.

In 1975, the Florida legislature mandated that land strip mined for phosphate be reclaimed. Regulations require that reclaimed lands have gentle slopes and vegetative cover necessary to protect water quality and to provide flood and erosion control. Reclamation of the mined-out area commonly involves backfilling the pits with onsite overburden displaced during mining. Additionally, the large volumes of waste sand and clay remaining after the beneficiation process, which separates phosphate ore from the matrix, are either returned to the pits or clay-settling ponds during the process of reclamation. The reclaimed sites backfilled with overburden or overburden and sand-tailings are graded and contoured to provide the required land-surface configuration and then revegetated. The sites reclaimed with clay backfill are elevated settling ponds that hold the viscous clay during the consolidation process that occurs over a period of years. Revegetation of a reclaimed area commonly involves establishing either a wetland, a hardwood forest. or an area of mixed vegetation referred to as scrub. For all of these systems, the length of time that the soils remain saturated or dry is critical because the depth to ground water and its seasonal variation can affect the survival of the trees and other plants. The land-use plan, developed by regulatory agencies that oversee reclamation practices of the phosphate industry, generally includes measures to establish and maintain favorable hydrologic conditions for the intended land use.

The hydrology and water quality of small basins (less than $1 \mathrm{mi}^{2}$ ) in west-central Florida are poorly defined. This is particulariy true of small basins in phosphate-mining areas that have been reclaimed by various methods. The need for a better understanding of the hydrologic characteristics of these reclaimed basins and how they compare with those of natural systems led the U.S. Geological Survey (USGS), working in cooperation with Florida Institute of Phosphate Research (FIPR), to undertake this study during 1988-90.

\section{Purpose and Scope}

This report presents the results of a study conducted to describe and compare the characteristics of surface-water and ground-water systems in small unmined and reclaimed phosphate-mined basins in west-central Florida. The hydrologic characteristics and water quality of three small unmined basins ( 88 to 460 acres) and five small reclaimed basins ( 46 to 250 acres) are evaluated. The unmined basins represent natural conditions in areas unaffected by phosphate mining. The five reclaimed basins represent four types of areas. Two reclaimed basins are backfilled with clay derived from ore processing, one basin is backfilled with a sand and clay mixture, one basin is backfilled with sand-tailings and capped with overburden, and one basin is backfilled with overburden. For purposes of this report, the reclaimed basins are referred to as clay-settling basins, a sand-clay settling basin, an overburden-capped sand-tailings basin, and a contoured-overburden basin.

Data were collected within the eight small basins from June 1988 to September 1990. Surface runoff was determined from continuous streamflow records. Flow-duration curves were developed to estimate the percent of time specific discharges were equaled or exceeded, and the responses of streamflow and ground-water levels to precipitation were evaluated. Boxplots and trilinear diagrams were used to compare water quality among sites.

\section{Previous Investigations}

Several hydrologic, geologic, and water-quality investigations have been completed for the study area. These include an evaluation of the ground-water resources in Polk County (Stewart, 1966); an appraisal of the shallow groundwater resources of the upper Peace and Alafia River basins (Hutchinson, 1978); an evaluation of the effects of phosphate industry processing wastes on ground-water quality (Miller and Sutcliffe, 1983); the geohydrology of the aquifer systems in southwest Florida (Duerr and others, 1987); and the lithostratigraphy of the Hawthorn Group (Miocene) of Florida (Scott, 1988).

\section{Acknowledgments}

The authors gratefully acknowledge the cooperation and technical assistance from Steven G. Richardson and Richard F. McFarlin of the Florida Institute of Phosphate Research, members of the Florida Institute of Phosphate Research Hydrology Advisory Committee, and personnel of the phosphate companies participating in the study. These companies include Agrico Chemical Co., C.F. Industries, W.R. Grace Chemical Co., International Minerals and Chemical Corp., and Mobil Chemical Co. Special thanks are extended to Charles Paxton of the National Weather Service for providing access to a continuous remote storm-tracking system (RADAP II).

\section{DESCRIPTION OF THE STUDY AREA}

The study area encompasses about $350 \mathrm{mi}^{2}$ of the westcentral Florida phosphate district. The eight basins included in this study are at or near the heavily mined "four corners area" where the Hillsborough, Polk, Manatee, and Hardee County lines intersect (fig. 2). The locations of phosphatemining areas in west-central Florida are shown in figure 3. Approximately 218,229 acres have been mined and 114,872 


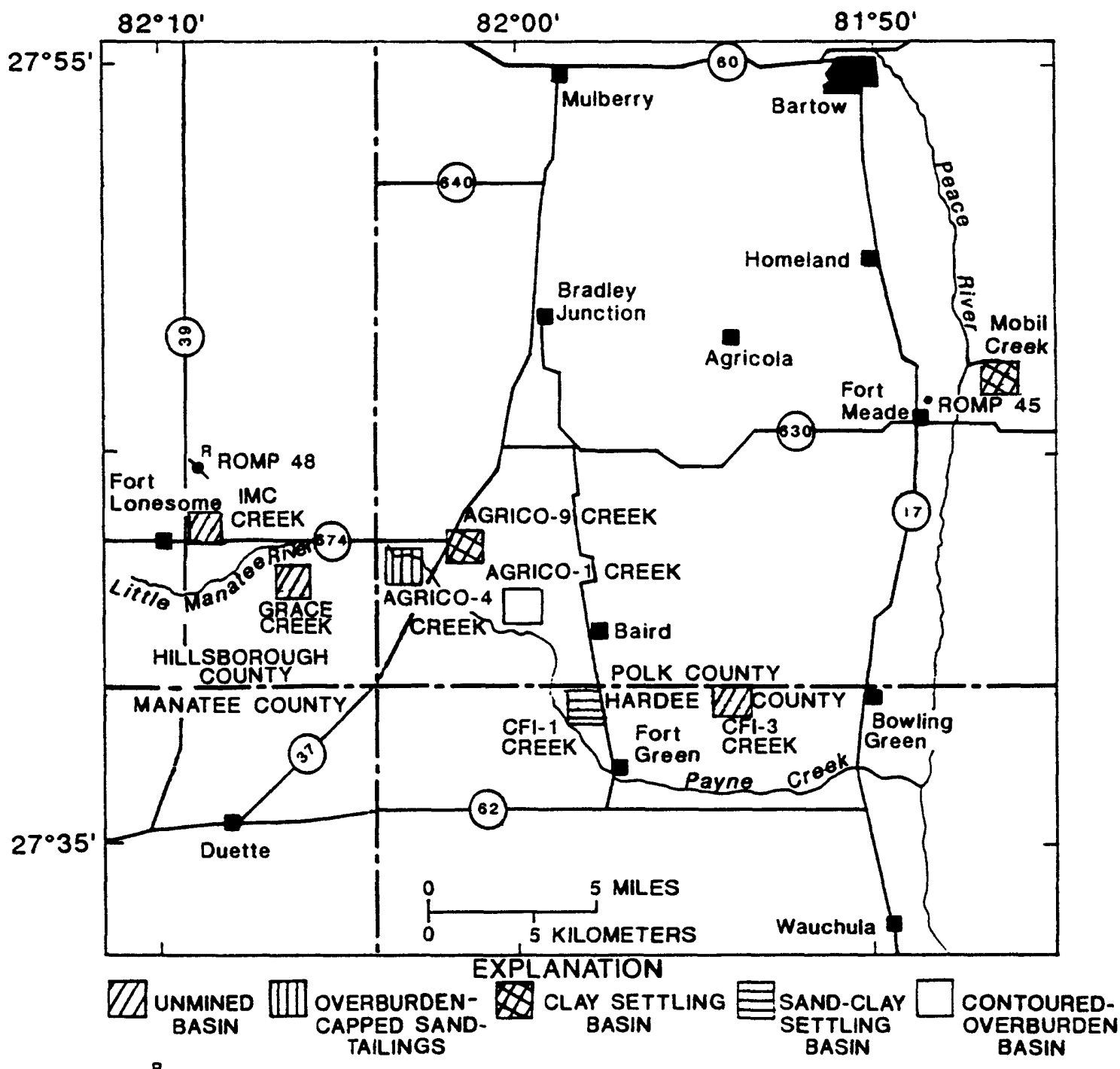

ROMP 48 INTERMEDIATE AQUIFER SYSTEM WELL WITH CONTINUOUS RECORDER

Figure 2. Locations of basins and ROMP well 48.

acres have been reclaimed (Long and Orne, 1990). The phosphate industry owns and has received regulatory approval for permits to mine approximately 119,000 acres. Phosphate companies also own approximately 104,000 acres of phosphate reserves that will be available for mining, contingent upon regulatory approval.

Three unmined basins and five mined and reclaimed basins were evaluated in this study. The unmined basins are the IMC Creek, Grace Creek, and CFI-3 Creek basins (fig. 2). The hydrologic characteristics of these basins represent background conditions in undisturbed basins. The reclaimed basins evaluated include two clay-settling basins (Mobil Creek and Agrico-9 Creek), a sand-clay settling basin (CFI-1 Creek), an overburden-capped sand-tailings basin (Agrico-4 Creek), and a contoured-overburden basin (Agrico-1 Creek) (fig. 2). All eight basins are within a few miles of one another in the same physiographic province and have similar geologic, hydrologic, and climatic conditions.

\section{Physiography and Soils}

The limit of the phosphate-mined area lies within the Polk Upland and De Soto Plain physiographic provinces (fig. 4). The Lakeland Ridge lies at the northeastern edge of the study area and the Gulf Coastal Lowlands lies at the southwest corner. Land-surface altitude generally ranges from 100 to $130 \mathrm{ft}$ above sea level. Erosion of the siliclastic surficial deposits is the principal factor that controls topography within the study area. 


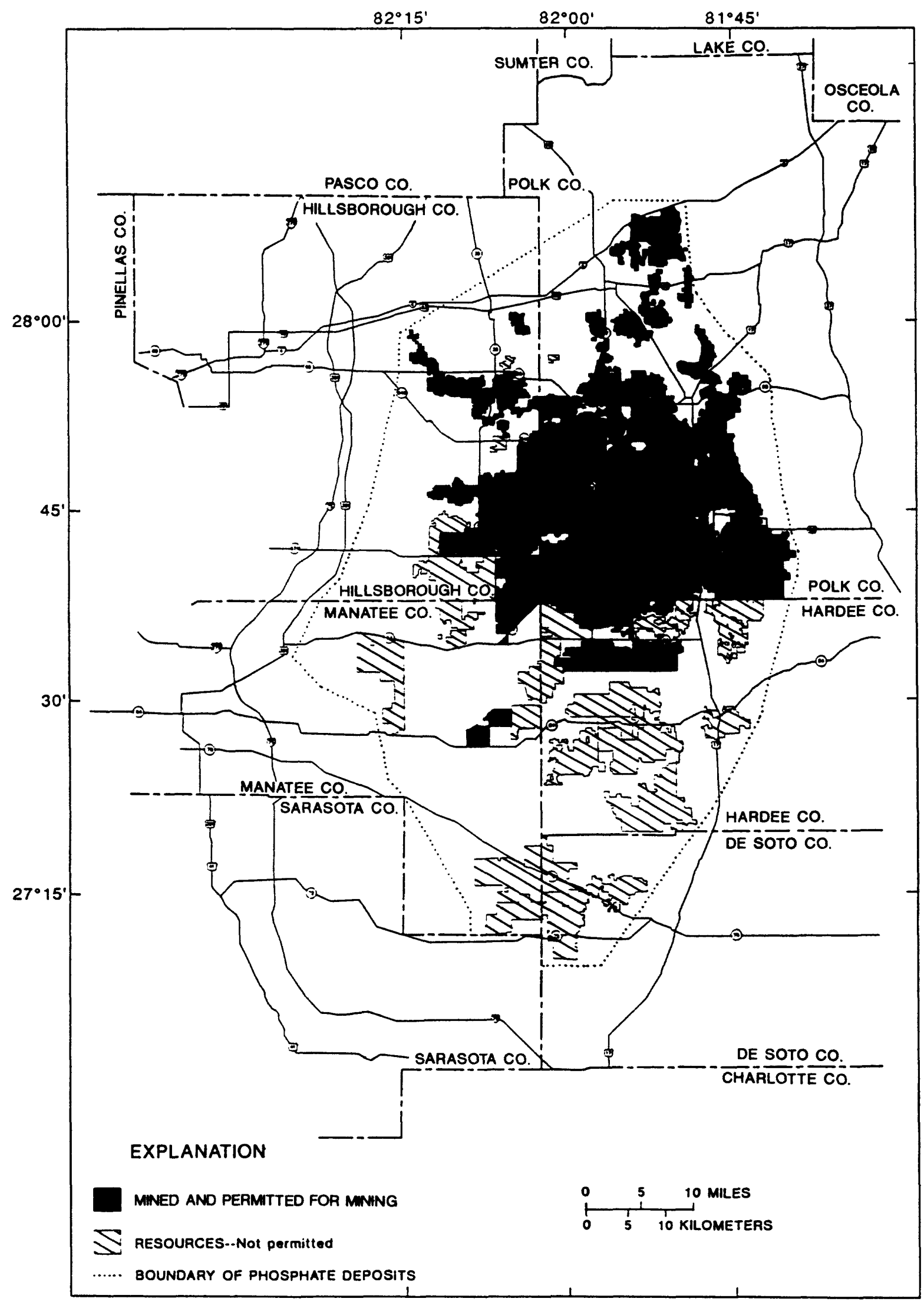

Figure 3. Location of phosphate-mined area, area permitted for future mining, and unpermitted area owned by phosphate companies. (Modified from Long and Orne, 1990.) 


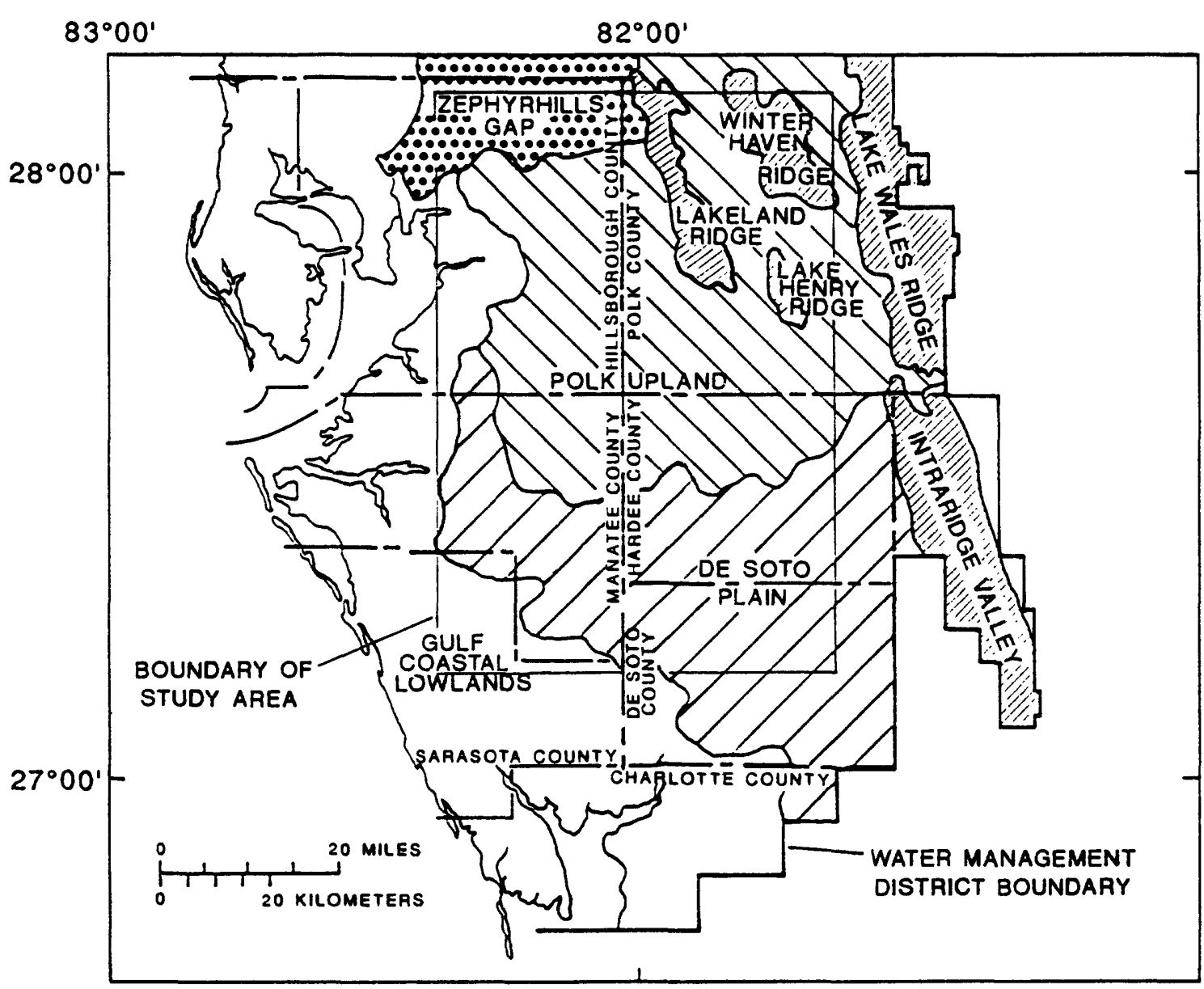

Figure 4. Physiography of the study area. (Modified from White, 1970.)

Three major soil groups have been identified in the study area. The first group, the Zolfo-Tavares association, occurs along the Little Manatee River and Payne Creek (fig. 2). This group consists of nearly level and gently sloping, poorly drained to moderately well-drained soils that are sandy throughout. The second group, Pomona-MyakkaSmyrna association, is scattered throughout the study area and is characterized by nearly level, poorly drained, sandy soils; some are underlain by loamy material. The third group, Arents-Hydraquents-Neilhurst association, is made up of soils that have been strip mined for phosphate (U.S. Department of Agriculture, 1990).

\section{Climate}

The climate in the study area is subtropical and generally is characterized by high average annual rainfall and temperatures. Intense rainfall generated by local convective thunderstorm activity during the summer months (June through September) accounts for about 60 percent of the annual rainfall, whereas periodic cold fronts account for most of the rainfall during the winter months (December through March). The nearest long-term weather station is about $10 \mathrm{mi}$ southeast of the study area at the town of Wauchula in Hardee County (fig. 2) where the mean annual (normal) rainfall is 53.09 in. based on the 30-year period 1951-80 (National Oceanic and Atmospheric Administration, 1990). The mean annual temperature at Wauchula is $74^{\circ} \mathrm{F}$, and the mean monthly temperatures range from $82^{\circ}$ in August to $61^{\circ} \mathrm{F}$ in January (National Oceanic and Atmospheric Administration, 1990).

The monthly rainfall for the period $1988-90$ and the long-term mean monthly rainfall at Wauchula are shown in figure 5. Records from rainfall gages in the study area, described later in this report, indicate that the monthly rainfall trends in each of the study basins during the study period were consistent with the monthly trends at the Wauchula long-term station. Rainfall departures from the long-term average totaled $21.79 \mathrm{in}$. below normal during 1988-90, and abnormally dry conditions were prevalent during much of the data-collection period. The rainfall deficit directly affected the hydrologic characteristics in each of the study basins and resulted in reduced streamflow and low ground-water levels. 


\section{Surface Drainage}

The eight basins evaluated in this study are small subbasins that range from 0.07 to $0.66 \mathrm{mi}^{2}$ and are contained within larger regional drainage networks. The unmined basins in eastern Hillsborough County, IMC Creek and Grace Creek, drain directly into the Little Manatee River (fig. 2). The reclaimed basins, Agrico-1 Creek, Agrico-4 Creek, and Agrico-9 Creek, in southwestern Polk County and the unmined basin, CFI-3 Creek, and the reclaimed basin, CFI-1 Creek, in northern Hardee County drain into Payne Creek. The reclaimed basin in Polk County, Mobil Creek, east of Fort Meade drains into the Peace River.

\section{Surficial Aquifer System}

The surficial aquifer system consists of undifferentiated clastic deposits of Holocene and Pleistocene age overlying the intermediate aquifer system. The surficial deposits are predominantly fine to medium sand, becoming increasingly clayey and phosphatic with depth (Hutchinson, 1978). The surficial aquifer system ranges in thickness from a few feet to more than $100 \mathrm{ft}$ in the sand ridges and ranges from approximately 25 to $50 \mathrm{ft}$ thick throughout most of the study area.

The surficial aquifer system is unconfined and is a major source of recharge to the underlying aquifer systems. Water from rainfall, streams, and other sources that infiltrates

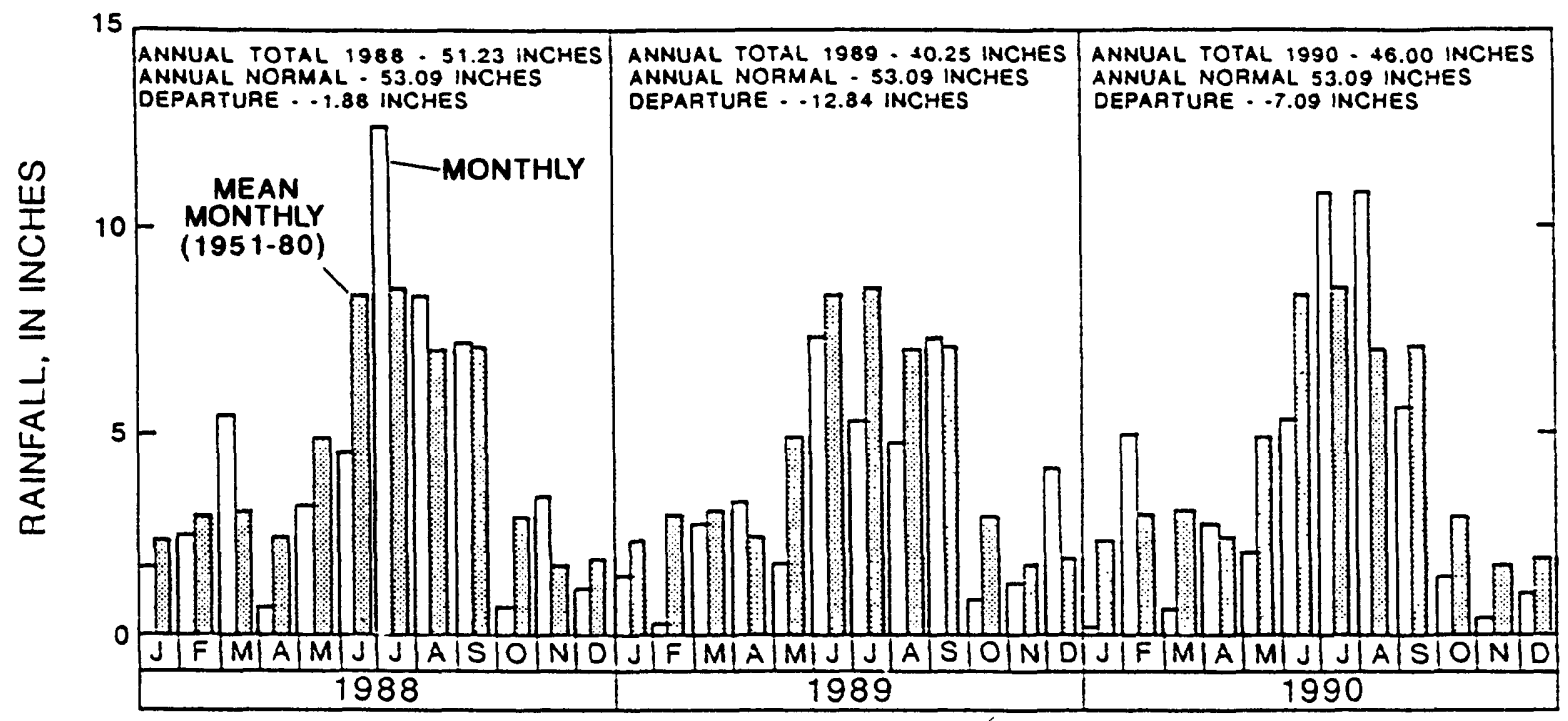

Figure 5. Monthly rainfall, 1988-90, and mean monthly rainfall at Wauchula, Fla.

The natural dendritic drainage network of incised channels has been altered during mining of the basin. The reclaimed basins characteristically have a flat to gently rolling topography that is drained by poorly developed networks of ditches and swales. Storm runoff can be relatively high, however, if the permeability of the reworked overburden or other fill material is low.

\section{HYDROGEOLOGIC FRAMEWORK}

The three principal hydrogeologic units in the study area are the surficial aquifer system, the intermediate aquifer system, and the Upper Floridan aquifer (fig. 6). The hydrogeologic units are presented in table 1 by system, series, stratigraphic unit, and location. to the water table (surficial aquifer system) generally flows from the higher recharge areas to discharge areas that are normally in topographically low places such as stream valleys, lakes and wetlands, and the sea (Vecchioli and others, 1990). The hydraulic properties of the surficial aquifer system vary with saturated thickness and lithology (Duerr and others, 1987). Hutchinson (1978, p. 20) reported transmissivities from two aquifer tests in the study area to be approximately 1,600 and $2,200 \mathrm{ft} 2 / \mathrm{d}$ with storage coefficients of approximately 0.05 and 0.005 , respectively. The hydraulic conductivity of the surficial aquifer system at the unmined basins was estimated from the results of nine single-well slug-recovery aquifer tests and ranged from less than 0.1 to $17.9 \mathrm{ft} / \mathrm{d}$ (table 2).

The surficial aquifer system is an important source of water supply for livestock production in the study area. The aquifer overlies the material containing phosphate in quantities suitable for mining and must be locally dewatered before strip-mining operations can begin to remove the overburden. 


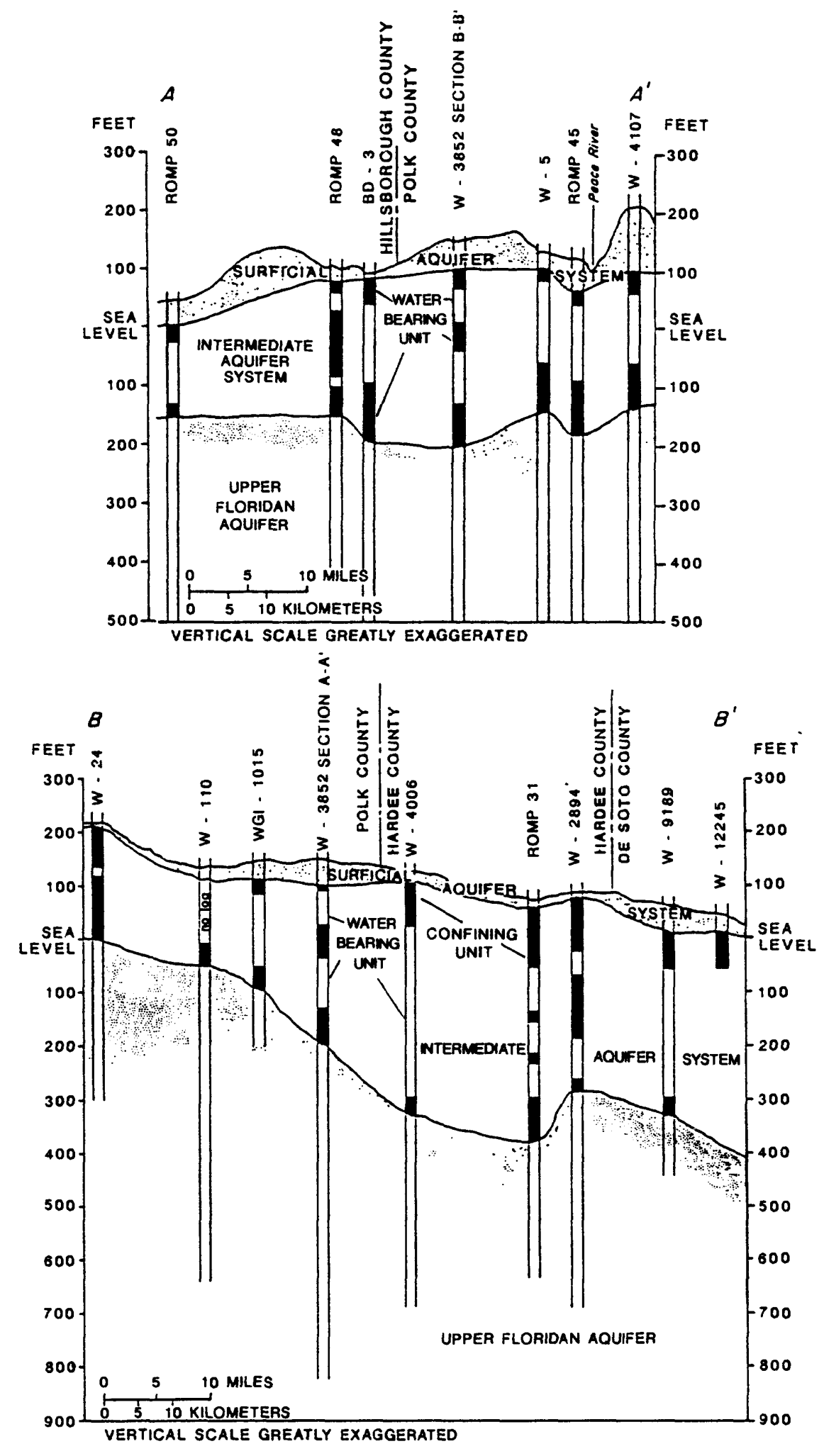

Figure 6. Hydrogeologic sections $A-A^{\prime}$ and $B-B^{\prime}$. (Locations of sections are shown in figure 1. Modified from Duerr and others, 1987.) 
Table 1. Geologic and hydrogeologic units in the study area.

\begin{tabular}{|c|c|c|c|c|c|c|c|}
\hline \multirow{2}{*}{ SYSTEM } & \multirow[b]{2}{*}{ SERIES } & \multirow{2}{*}{\multicolumn{2}{|c|}{$\begin{array}{c}\text { STRATIGRAPHIC } \\
\text { UNIT }\end{array}$}} & \multicolumn{4}{|c|}{ HYDROGEOLOGIC UNIT } \\
\hline & & & & UNIT & $\begin{array}{l}\text { NOATH OF } \\
\text { TAMPA BAY }\end{array}$ & $\begin{array}{l}\text { EAST OF } \\
\text { TAMPA BAY }\end{array}$ & SOUTH OF TAMPA BAY \\
\hline \multirow{2}{*}{ OUATERMARY } & \multirow{2}{*}{$\begin{array}{l}\text { HOLOCENE } \\
\text { PLEISTOCENE }\end{array}$} & \multicolumn{2}{|c|}{$\begin{array}{l}\text { TERAACE } \\
\text { DEPOSITS }\end{array}$} & \multirow{2}{*}{$\begin{array}{l}\text { SUAFICIAL } \\
\text { AOUIFER } \\
\text { SYSTEM }\end{array}$} & \multirow{2}{*}{$\begin{array}{l}\text { ABSENT OR } \\
\text { SURFICIAL AOUIFER } \\
\text { SYSTEM }\end{array}$} & \multirow{2}{*}{$\begin{array}{l}\text { SURFICIAL } \\
\text { AOUIFER } \\
\text { SYSTEM }\end{array}$} & \multirow{2}{*}{$\begin{array}{l}\text { SURFICIAL } \\
\text { AQUIFER } \\
\text { SYSTEM }\end{array}$} \\
\hline & & \multirow{2}{*}{\multicolumn{2}{|c|}{$\begin{array}{l}\text { CALOOSAHATCHEE } \\
\text { MARL AND } \\
\text { TAMIAMI } \\
\text { FORMATION }\end{array}$}} & & & & \\
\hline \multirow{11}{*}{ TERTIAAY } & PLIOCENE & & & \multirow{5}{*}{$\begin{array}{c}\text { INTERMEDIATE } \\
\text { AQUIFER } \\
\text { SYSTEM OR } \\
\text { INTERMEDIATE } \\
\text { CONFIMING } \\
\text { UNIT }^{2}\end{array}$} & \multirow{5}{*}{$\begin{array}{l}\text { ABSENT OR } \\
\text { INTERMEDIATE }\end{array}$} & $\begin{array}{l}\text { UPPEA CONFINING } \\
\text { UNIT }\end{array}$ & $\begin{array}{c}\text { SEMMCONFINING } \\
\text { UNIT } 4\end{array}$ \\
\hline & \multirow{4}{*}{ MIOCENE } & \multirow{4}{*}{ 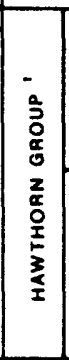 } & \multirow{2}{*}{ 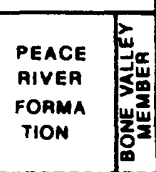 } & & & \multirow{3}{*}{$\begin{array}{l}\text { INTERMEDIATE } \\
\text { AQUIFER }^{2}\end{array}$} & $\begin{array}{l}\text { TAMIAMH-UPPER } \\
\text { MAWTHORN } \\
\text { AOUIFER } 5\end{array}$ \\
\hline & & & & & & & $\begin{array}{c}\text { SEMICONFINING } \\
\text { UNIT }\end{array}$ \\
\hline & & & \multirow[t]{2}{*}{$\begin{array}{c}\text { ARCADIA } \\
\text { FORMATION }\end{array}$} & & & & $\begin{array}{l}\text { LOWER HAWTHORN- } \\
\text { UPPER TAMPA } \\
\text { AQUIFER } 5\end{array}$ \\
\hline & & & & & & $\begin{array}{c}\text { LOWER CONFINING } \\
\text { UNIT }{ }^{2}\end{array}$ & $\begin{array}{c}\text { LOWER TAMPA } \\
\text { SEMICONFINING } \\
\text { UNIT 4 }\end{array}$ \\
\hline & OLIGOCENE & \multicolumn{2}{|c|}{$\begin{array}{l}\text { SUWANNEE } \\
\text { LIMESTONE }\end{array}$} & \multirow{6}{*}{$\begin{array}{l}\text { FLOAIOAN } \\
\text { AOUIFER } \\
\text { SYSTEM }^{3}\end{array}$} & \multirow{4}{*}{$\begin{array}{l}\text { FLOAIDAN } \\
\text { AOUIFER }^{3}\end{array}$} & \multirow[b]{2}{*}{ UPPEA } & $\begin{array}{l}\text { SUWANNEE } \\
\text { PERMEABLE } \\
\text { ZONE 4 }\end{array}$ \\
\hline & \multirow{4}{*}{ EOCENE } & \multicolumn{2}{|c|}{$\begin{array}{l}\text { OCALA } \\
\text { LIMESTONE }\end{array}$} & & & & $\begin{array}{l}\text { LOWER SUWANMEE. } \\
\text { OCALA SEMICONFIMING } \\
\text { UNIT }\end{array}$ \\
\hline & & \multirow{3}{*}{\multicolumn{2}{|c|}{$\begin{array}{l}\text { AVON PAAK } \\
\text { FORMATION }\end{array}$}} & & & AOUIFER ${ }^{3}$ & $\begin{array}{l}\text { OCALA-AVON PARK } \\
\text { MODERATELY } \\
\text { PERMEABLE ZONE }\end{array}$ \\
\hline & & & & & & & $\begin{array}{l}\text { AVON PARK } \\
\text { HIGHLY PERMEABLE } \\
\text { ZONE } 4\end{array}$ \\
\hline & & & & & $\begin{array}{l}\text { MIDDLE CONFINING } \\
\text { UNIT }\end{array}$ & $\begin{array}{l}\text { MIDDLE CONFINING } \\
\text { UNIT }{ }^{3}\end{array}$ & $\begin{array}{l}\text { MODLE } \\
\text { CONFINING UNHT } 3\end{array}$ \\
\hline & PALEOCENE & Ano & $\begin{array}{l}\text { OLDSMAR } \\
\text { CEDMA KEYS } \\
\text { OAMAATIONS }\end{array}$ & & $\begin{array}{l}\text { LOWEA FLOAIDAN } \\
\text { AOUIFEA }\end{array}$ & $\begin{array}{l}\text { LOWER FLOAIDAN } \\
\text { AOUIFER }^{3}\end{array}$ & $\begin{array}{l}\text { LOWER FLORIDAN } \\
\text { AOUIFER }\end{array}$ \\
\hline
\end{tabular}

1 BASED ON MOMEMGLATUAE OF SCOTT (1988)

2 BASED ON MOMENCLATURE OF SOUTHEASTERN GEOLOGICAL SOCIETY (1986)

3 BASED ON MOMENCLATUAE OF MILLER (1988)

4 BASED ON NOMENCLATUAE OF HUTCHINSON (1091)

5 BASED ON NOMENCLATURE OF WOLANSKY (1983)

\section{Intermediate Aquifer System}

The intermediate aquifer system in the study area consists of Miocene age deposits of the Hawthorn Group of Scott (1988). The system constitutes a permeable carbonate aquifer that is overlain and underlain by relatively impermeable clastic deposits. The upper confining unit consists of sandy and calcareous clay of the phosphate-rich Bone Valley Member of the Peace River Formation'. At the three unmined basins, a 5- to 15-ft-thick limestone layer occurs within the upper confining unit, but because of a lack of significant data on the hydraulic properties of this layer, it is considered part of the upper confining unit for purposes of this report. The - intermediate aquifer system consists of water-bearing lime- stone and dolomite within the Arcadia Formation. The lower confining unit consists of sandy clay at the base of the Tampa Member of the Arcadia Formation. The intermediate aquifer system ranges in thickness from approximately 125 to $425 \mathrm{ft}$ in the study area, thickening from north to south.

The potentiometric surface of the intermediate aquifer system in May and September 1988 are shown in figure 7. The May 1988 map (Lewelling, 1989) represents the potentiometric surface near the end of the dry season when groundwater withdrawals are greatest and water levels generally are at their annual low. The September 1988 map (Barr, 1989) shows the potentiometric surface at the end of the summer wet season (June-September) when withdrawals are much less and water levels usually are near their annual maximum.

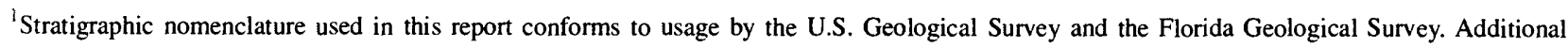
references are given in table 1 . 
Table 2. Summary of aquifer test results

[ft, feet; $\mathrm{ft}^{2} / \mathrm{d}$, foot squared per day; BLSD, below land surface datum; $\mathrm{ft} / \mathrm{d}$, feet per day; $\mathrm{SA}$, surficial aquifer system; <, less than]

\begin{tabular}{|c|c|c|c|c|c|c|c|c|c|c|c|c|}
\hline $\begin{array}{c}\text { Well } \\
\text { number }\end{array}$ & $\begin{array}{l}\text { Latitude- } \\
\text { longitude }\end{array}$ & $\begin{array}{c}\text { Altitude } \\
\text { of land } \\
\text { surface } \\
(\mathrm{ft})\end{array}$ & Aquifer & $\begin{array}{l}\text { Aquifer } \\
\text { thick- } \\
\text { ness } \\
\text { (ft) }\end{array}$ & $\begin{array}{c}\text { Well } \\
\text { depth } \\
\text { (ft) }\end{array}$ & $\begin{array}{l}\text { Screen } \\
\text { length } \\
(\mathrm{ft})\end{array}$ & $\begin{array}{c}\text { Static } \\
\text { water } \\
\text { level } \\
\text { (BLSD) }\end{array}$ & $\begin{array}{l}\text { Aquifer } \\
\text { transmis- } \\
\text { sivity } \\
\left(\mathrm{ft}^{2} / \mathrm{d}\right)\end{array}$ & $\begin{array}{l}\text { Hydraulic } \\
\text { conduc- } \\
\text { tivity } \\
\text { (ft/d) }\end{array}$ & $\begin{array}{c}\text { Type of } \\
\text { test }\end{array}$ & $\begin{array}{l}\text { Analytical } \\
\text { technique }\end{array}$ & $\begin{array}{c}\text { Type of } \\
\text { reclama- } \\
\text { tion }\end{array}$ \\
\hline
\end{tabular}

$\begin{array}{lll}\text { IMC-1 } & 274222082072601 & 114 \\ \text { IMC-2 } & 274241082072001 & 117 \\ \text { IMC-4 } & 274228082071601 & 111\end{array}$

\section{IMC Creek basin near Fort Lonesome}

$\begin{array}{llllll}\mathrm{SA} & 36 & 20 & 10 & 8.05 & 58\end{array}$

$\begin{array}{lllllllll} & \\ \text { IMC-4 } & 274228082071601 & 111 & \text { SA } & 36 & 17 & 10 & 5.06 & 11\end{array}$

Grace Creek basin near Fort Lonesome

$\begin{array}{lllllllll}\text { WRG-2 } & 274132082045201 & 120 & \text { SA } & 40 & 18 & 10 & 3.18 & 480\end{array}$

$\begin{array}{lllllllll}\text { WRG-3 } & 274134082043701 & 131 & \text { SA } & 40 & 18 & 10 & 3.48 & 90\end{array}$

WRG-6 $274112082044901 \quad 132 \quad$ SA

$\begin{array}{llll}17 & 10 & 4.45 & 720\end{array}$

720

$\begin{array}{clll}12 & \text { recovery } & \text { Bouwer/Rice } & \text { Unmined } \\ 2.2 & \text { slug } & \text { Bouwer/Rice } & \text { Unmined } \\ 17.9 & \text { recovery } & \text { Bouwer/Rice } & \text { Unmined }\end{array}$

\section{CFI-3 Creek basin near Fort Green}

\begin{tabular}{|c|c|c|c|c|c|c|c|c|c|c|c|}
\hline CFI3-1 & 273801081540201 & 125 & SA & 25 & 19 & 10 & 3.92 & 80 & 3.2 & recovery & Bouwer/Rice \\
\hline CFI3-2 & 273815081540001 & 126 & SA & 25 & 13 & 10 & 4.31 & 2.5 & .1 & slug & Bouwer/Rice \\
\hline CFI3-5 & 273808081541201 & 127 & SA & 25 & 13 & 10 & 4.92 & 2.5 & .1 & slug & Bouwer/Rice \\
\hline
\end{tabular}

Mobil Creek basin near Fort Meade

$\begin{array}{lllllllllllll}\text { MBL-2 } & 274608081454101 & 114 & \text { SA } & 24 & 22 & 10 & 6.93 & 7.2 & .3 & \text { recovery } & \text { Bouwer/Rice } & \begin{array}{l}\text { Clay- } \\ \text { settling }\end{array} \\ \text { MBL-6 } & 274600081460201 & 106 & \text { SA } & 24 & 21 & 10 & 6.81 & .24 & <.01 & \text { slug } & \begin{array}{l}\text { Bouwer/Rice } \\ \text { Clay- } \\ \text { settling }\end{array} \\ \text { MBL-8 } & 274606081455201 & 108 & \text { SA } & 24 & 20 & 10 & 12.79 & 10 & \begin{array}{l}\text { Clay- } \\ \text { settling }\end{array}\end{array}$

Agrico-9 Creek basin near Fort Lonesome

$\begin{array}{lllllllll}\text { AGR9 5 } & 274222082001601 & 147 & \text { SA } & 40 & 20 & 10 & 4.39 & 32 \\ \text { AGR9-12 } 274206082003701 & 137 & \text { SA } & 40 & 17 & 10 & 3.84 & 48\end{array}$

CFI-1 Creek basin near Fort Green

$\begin{array}{lllllllll}\text { CFI1-1 } & 273723081570601 & 127 & \text { SA } & 47 & 20 & 10 & 9.61 & 517 \\ \text { CFI1-5 } & 273706081565601 & 127 & \text { SA } & 47 & 20 & 10 & 11.02 & 216 \\ \text { CFI1-7 } & 273701081564801 & 125 & \text { SA } & 47 & 20 & 10 & 8.74 & 56\end{array}$

Agrico-4 Creek basin near Fort Lonesome

$\begin{array}{lllllllll}\text { AGR4-2 } & 274127082020801 & 134 & \text { SA } & 34 & 20 & 10 & 2.65 & 2,000\end{array}$

$\begin{array}{lllllllll}\text { AGR4-3 } & 274133082022301 & 134 & \text { SA } & 34 & 20 & 10 & 1.44 & 286\end{array}$

Agrico-1 Creek basin near Fort Green

$\begin{array}{lllllllll}\text { AGR1-B } & 274034081591903 & 130 & \text { SA } & 35 & 26 & 10 & 3.10 & 18\end{array}$

$\begin{array}{lllllllll}\text { AGR1-8 } & 274047081590701 & 131 & \text { SA } & 35 & 18 & 10 & 3.32 & 7\end{array}$

7

$$
\begin{aligned}
& .8 \text { recovery Bouwer/Rice Clay- } \\
& \text { settling } \\
& 1.2 \text { recovery Bouwer/Rice Clay- } \\
& \text { settling }
\end{aligned}
$$




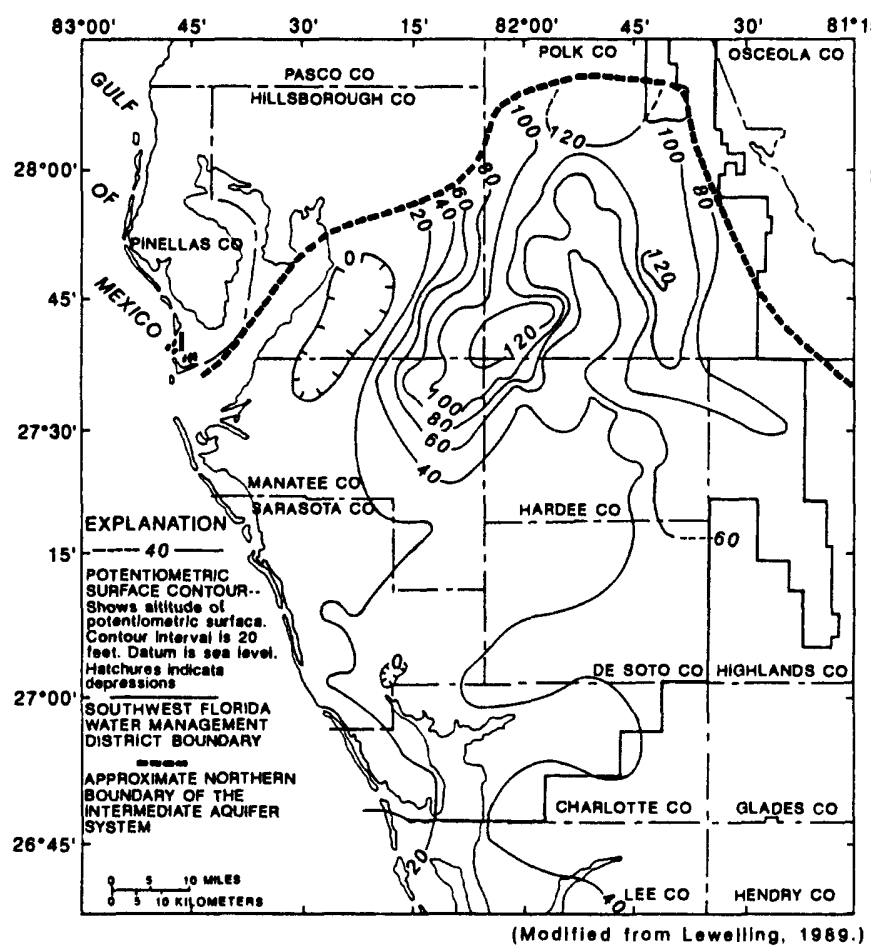

MAY 1988

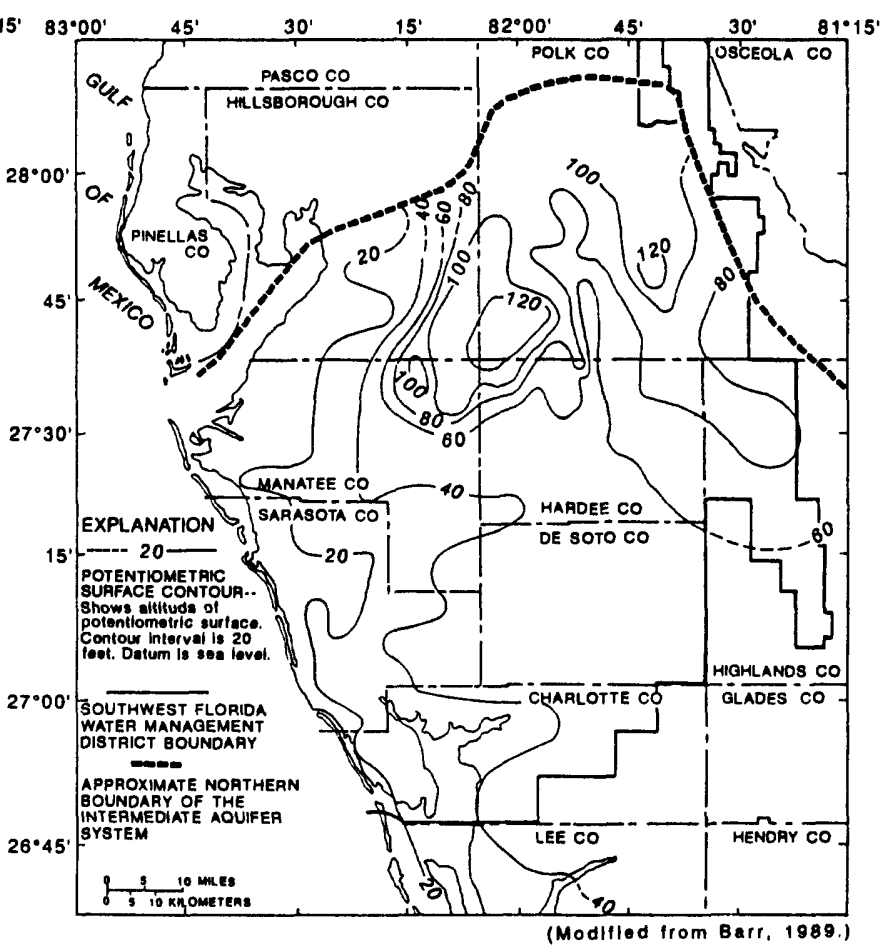

SEPTEMBER 1988

Figure 7. Potentiometric surface of the intermediate aquifer system, May and September 1988.

Throughout the study area, differences in the potentiometric surface between the May 1988 low and the September 1988 high were small (less than $8 \mathrm{ft}$ ). The aquifer is recharged by downward leakage from the surficial aquifer system and more directly through sinkholes and abandoned mine pits that breach the semiconfining units (Hutchinson, 1978). The mining of the phosphate matrix, which constitutes part of the upper confining unit of the intermediate aquifer system, permits direct hydraulic connection with the surficial aquifer system. The head difference between the water table in the surficial aquifer system and the potentiometric surface of the intermediate aquifer system is small in mined areas, which indicates good hydraulic connection between the aquifers. The intermediate aquifer system is a major source of water throughout much of De Soto, Hardee, Highlands, Hillsborough, Manatee, and Polk Counties, although yields of individual wells and total withdrawals of water from the aquifer system generally are much less than from wells open to the deeper Upper Floridan aquifer (Duerr and others, 1987).

\section{Upper Floridan Aquifer}

The Upper Floridan aquifer, which underlies the intermediate aquifer system (table 1), is a vertically continuous sequence of carbonate rocks ranging in thickness from 1,000 to $1,200 \mathrm{ft}$ within the study area. The carbonate units include the Suwannee and Ocala Limestones and the Avon
Park Formation of Oligocene and Eocene age. The base is marked by the persistent occurrence of intergranular evaporites in the carbonates. The Upper Floridan aquifer is tapped by virtually all municipal, industrial, and agricultural production wells in the study area. The phosphate industry uses the highly permeable aquifer to supply large volumes of water to transport the phosphate-matrix slurry.

\section{DESCRIPTION OF MINING TECHNIQUES}

Initial site preparation for open-pit mining of phosphate deposits involves the removal of all vegetation. Typically, a deep trench is cut along the perimeter of the planned mine site to drain the surficial aquifer system, thus lowering the water table. The overburden, consisting of undifferentiated deposits ranging in thickness from 20 to $50 \mathrm{ft}$, is removed and cast into a previously mined-out cut to be reclaimed later. The exposed matrix layer of sand, clay, and phosphate ore, ranging in thickness from 5 to $10 \mathrm{ft}$, is stripped away and placed into a containment pit where high-pressure hoses inject water to create a slurry. The slurry is then pumped through a pipeline network to the beneficiation plant where the three major components of the matrix-phosphate ore, sand, and clay-are separated. The phosphate ore is sent offsite to the chemical plant for processing, and the sand and clay waste materials are later returned either to the mine pits or to the clay-settling ponds during reclamation. 


\section{RECLAMATION METHODS}

Phosphate deposits have been strip mined in west-central Florida since 1888 (Long and Orne, 1990). Mining of near-surface deposits has involved large tracts of land. Prior to the 1970 's, much of the mined land was abandoned as the mining expanded into adjacent areas. The postmining topography of land that had been mined generally was characterized by long, irregular rows of overburden spoil piles adjacent to elongated bodies of water. In 1975, the Florida Legislature mandated that all mined areas would be reclaimed because of the increasing loss of productive land. Reclamation by the phosphate industry prior to 1975 commonly was limited to commercially developing areas near expanding population centers. Since 1975, however, regulations require that a reclamation plan and the proposed method of reclaiming the land be approved by State and local agencies prior to mining.

Reclamation methods vary, but commonly involve backfilling mined areas with overburden or other materials (sand or clay) from ore-processing operations. The backfilled areas are then revegetated and returned to beneficial use. The reclaimed site may include lakes and wetlands, pasture, orchards, pine forests, and hardwood forests. A primary objective of the reclamation effort is to ensure that there is no degradation of the quality of ground water or of waters that receive runoff from the reclaimed lands. According to State and local agency regulations, one or more acres of wetlands must be preserved or restored for each acre affected by mining. Regulations also require that stormwater runoff from mined lands must not exceed the runoff of the premined land for rainfall events with recurrence intervals of 25 years or less.

Three of the four methods commonly used to reclaim the mined areas involve backfilling the areas with clays, sands, or sand-clay mixtures, which are waste products of the beneficiation process. The beneficiation plant separates the clays and sands from the phosphate ore. After beneficiation, the clay waste is difficult to dispose of because it typically swells to three times its original volume. Prior to mining, the clay fraction of the matrix has a solids content (weight of solids divided by total weight) of 48 percent (Garlanger and Fuleihan, 1983).

The most common reclamation method employed utilizes the large volume of clays separated during processing of the phosphate ore. Reclaiming land by backfilling mined areas with these clays requires the construction of an elevated dike at the perimeter of the mined-out area to form an impoundment. The dike typically is formed above the natural grade from onsite spoil material or from sand-tailings also produced during ore-processing operations. The clay is pumped as a slurry at about 3-percent solids from the beneficiation plant to the diked areas where it is allowed to settle and consolidate. The clay would have to consolidate to at least 33-percent solids to occupy the same volume it occupied prior to mining. The consolidation process typically requires several decades to achieve a final average solids content of 20 to 25 percent. The reclaimed settling areas commonly are regraded and planted to pasture. This type of reclamation accounts for 60 percent of reclaimed mined areas. For purposes of this report, areas reclaimed using this method are referred to as clay-settling areas.

Another reclamation method commonly used is to backfill the mined areas with a mixture of the sand and clay wastes from the beneficiation process (mixed in a ratio of $2: 1$, respectively). This mixture is pumped as a slurry to a diked settling area as with the method previously discussed. However, the mixture of these materials is easier to handle and the physical properties of the mixture eliminates the need for constructing high dikes (Keen and Sampson, 1983). For purposes of this report, areas reclaimed using this method are referred to as sand-clay settling areas.

A third reclamation method commonly used by the phosphate industry is to backfill the mined pits with the sand waste material from the beneficiation process. Once the pits are filled, the adjacent spoil piles are pushed over onto the sandtailings and graded to the desired topographic relief. For purposes of this report, areas reclaimed using this method are referred to as overburden-capped sand-tailings areas.

The last method of reclamation that will be discussed in this report involves backfilling only with onsite overburden spoil displaced during mining. The waste sand and clay fractions from the matrix mined at the site are redirected to other sites, which results in a smaller volume of material at the original site. The tops of the overburden spoil piles are pushed into the adjacent mine pits and contoured to final topographic configuration. The reclaimed areas are typically contoured into gently rolling hills interspersed with shallow lakes. These areas generally drain internally. The benefit of this method is minimal subsidence occurring after reclamation and the immediate availability of the land for other uses. For purposes of this report, areas reclaimed using this method are referred to as contoured-overburden areas.

\section{METHODS OF STUDY}

Data collection at each of the eight study basins included operation of a streamflow gaging station, a rainfallrecording gage (in each of the two largest basins, Grace Creek and Agrico-9 Creek, two rainfall gages were operated to enhance aerial coverage), continuous monitoring of water levels at two large-diameter wells completed in the surficial and intermediate aquifer systems, and periodic measurements of water levels in 10 to 13 small-diameter wells completed in the surficial aquifer system. Stream-stage and rainfall data were recorded at 15 -minute intervals, whereas water levels in the large-diameter wells were recorded at 1-hour intervals. Water levels in the small-diameter watertable wells were measured at about 6-week intervals. Ground-water levels measured in the wells were used to develop water-table maps for each basin. 
Low flows in streams draining the study basins were measured using a portable 3-in. Parshall flume. Altitudes of the gage datum or reference point for water-level and stage measurements at most of the surface-water and ground-water stations within each basin were determined using standard survey techniques. Stations at three basins in remote areas were surveyed to sea-level datum using a satellite-aided global positioning system (GPS). Drainage areas of the three unmined and the reclaimed Mobil Creek and CFI-1 Creek basins were determined from USGS 7.5-minute series topographic maps. The configuration of the basin boundaries for the Agrico-1 Creek, Agrico-4 Creek, and Agrico-9 Creek reclaimed basins were obtained from aerial photographs with topographic contours provided by Agrico Chemical Company.

The observation wells used to measure water levels in the surficial aquifer system at each of the basins were drilled with a solid-stem auger and constructed with 2-in.-diameter polyvinylchloride (PVC) casing and screen. Each well had a $10-\mathrm{ft}$ section of screen and was cased to a total depth of 12 to $26 \mathrm{ft}$ below land surface. Formation material was allowed to collapse around the well after the screen was set at the determined depth. Compressed air was used to clear and develop the well.

Hydraulic conductivity of the surficial aquifer system was determined through positive (slug) or negative (recovery) displacement of water in the well. The rate of change in water levels was measured using a transducer and was recorded on a data logger when a known volume was either inserted or removed from below the water table. Estimates of the hydraulic conductivity were determined from calculations described by Bower and Rice (1976, p. 424-425).

At the beginning of the study, reconnaissance waterquality samples were collected using the standard methods and techniques used by the USGS and described by Ward (1990). These samples were collected and shipped to a USGS laboratory for analysis of a broad range of chemical constituents, including major dissolved ions, trace elements, nutrients, and radiochemicals. In addition, bimonthly samples were collected and shipped to a USGS laboratory for measurement of specific conductance and $\mathrm{pH}$ and analysis of chloride, sulfate, alkalinity, orthophosphorus, and dissolved-solids concentrations. Water samples collected from streams in the study basins were analyzed for suspended solids using methods described by Skougstad and others (1979).

\section{DESCRIPTION AND HYDROLOGIC SETTING OF UNMINED BASINS}

Three small, rural, unmined basins-IMC Creek, Grace Creek, and CFI-3 Creek-were selected to evaluate the natural (background) hydrologic and water-quality characteristics in the study area. The basins were selected on the basis of their similarity in size and their locations within the west-central Florida phosphate-mining district.

\section{IMC Creek}

The IMC Creek basin is in southeastern Hillsborough County, 1 mi east of Fort Lonesome on State Road 674 (fig. 2). The basin consists mostly of gently sloping pastureland with a small wooded area of cultivated pine trees in the lower third of the basin. Land surface in the basin ranges from about $115 \mathrm{ft}$ above sea level at the upper boundary to about $90 \mathrm{ft}$ at the gaging station (fig. 8). The basin is triangular (approximately $2,000 \mathrm{ft}$ wide and 2,800 ft long) and has a slope of $47 \mathrm{ft} / \mathrm{mi}$. The gaged drainage area of the IMC Creek basin is approximately 110 acres $\left(0.17 \mathrm{mi}^{2}\right)$. Streamflow from the basin is seasonally intermittent. The headwaters of the undeveloped drainage network are in a pasture in the upper part of the basin. The lower part of the basin is characterized by several poorly defined tributary channels that converge to create a single channel upstream from the streamflow-gaging station (IMC Creek near Fort Lonesome). The natural drainage has been diverted through a double-barrel, 5 -ft culvert beneath State Road 674 to the gaging station. Discharge from the basin during the study period ranged from 0 to $10.5 \mathrm{ft}^{3} / \mathrm{s}$ $\left(62\left(\mathrm{ft}^{3} / \mathrm{s}\right) / \mathrm{mi}^{2}\right)$.

Continuous water-level data for the surficial aquifer system in this basin were collected at a 25 -ft-deep well (IMC-SH well near Fort Lonesome). Water levels in this well ranged from $107.71 \mathrm{ft}$ above sea level $(0.11 \mathrm{ft}$ above land surface) in September 1988 to $100.63 \mathrm{ft}$ above sea level $(6.97 \mathrm{ft}$ below land surface) in June 1990 (fig. 9). Rises in the water level indicate recharge to the surficial aquifer system by the infiltration of rainfall.

The configuration of the water table in the surficial aquifer system in June and October 1989 is shown in figure 10. These maps indicate water-level increases of approximately $3 \mathrm{ft}$ between June and October near the northern boundary and about $2 \mathrm{ft}$ near the southern boundary. Ground-water flow generally is perpendicular to the contours of equal water-table altitude and toward areas of lower water levels. Shallow ground water in the basin flows southward toward a small wetland area near the mouth of the basin based on water-level measurements in well IMC-SH and in 13 shallow observation wells. Water-level changes in the 13 observation wells were consistent throughout the basin (fig. 11).

The hydraulic conductivity of the surficial aquifer system, as computed from recovery tests on the three IMC Creek wells, ranged from 0.3 to $2.0 \mathrm{ft} / \mathrm{d}$ (table 2). Lithologic and gamma-ray logs of the 55-ft-deep well (IMC-DP well near Fort Lonesome) indicate the surficial aquifer system is about $20 \mathrm{ft}$ thick and overlies a 25 -ft-thick layer of clay, sand, and limestone that forms the upper confining unit of the intermediate aquifer system (fig. 12). The IMC-DP well originally was drilled to monitor the intermediate aquifer system, but was abandoned due to hydraulic connection between aquifers through the well bore.

Water levels in the intermediate aquifer system (fig. 9), monitored at a 61-ft-deep well (ROMP 48 Hawthorn well 
near Fort Lonesome) about $1.5 \mathrm{mi}$ north of the IMC Creek basin (fig. 2), indicate that the potentiometric surface at that site ranged from $96.14 \mathrm{ft}$ above sea level in September 1988 to $88.20 \mathrm{ft}$ above sea level in June 1990. The potentiometric surface in the confined intermediate aquifer system at ROMP 48 well averaged about $10 \mathrm{ft}$ lower than the water table in the unconfined surficial aquifer system. Differences between the potentiometric surface and the water table in the IMC Creek basin probably are similar to those at ROMP 48 well, although no data are available.

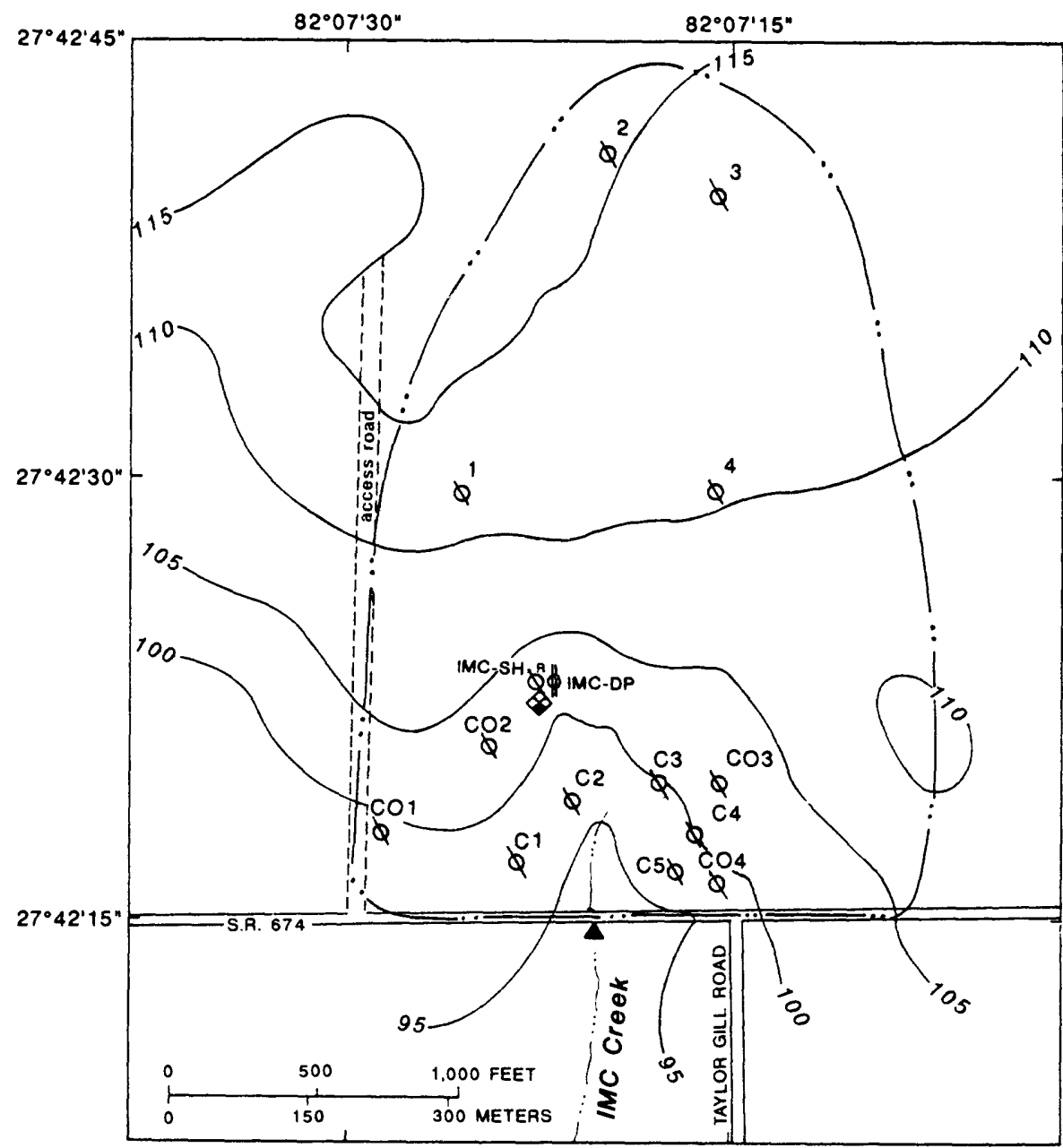

\section{EXPLANATION}

TOPOGRAPHIC CONTOUR--Showing altitude of land surface.
Contour interval 5 feet. Datum is sea level

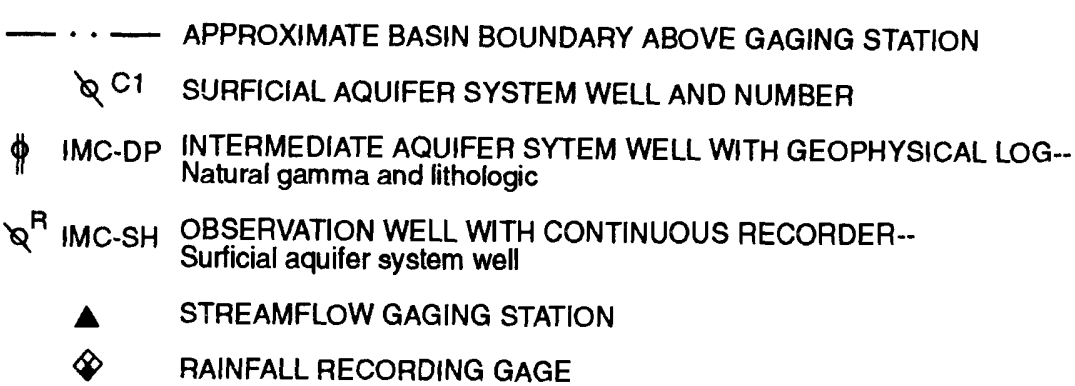

Figure 8. Location of IMC Creek basin, topography, and data-collection network. 

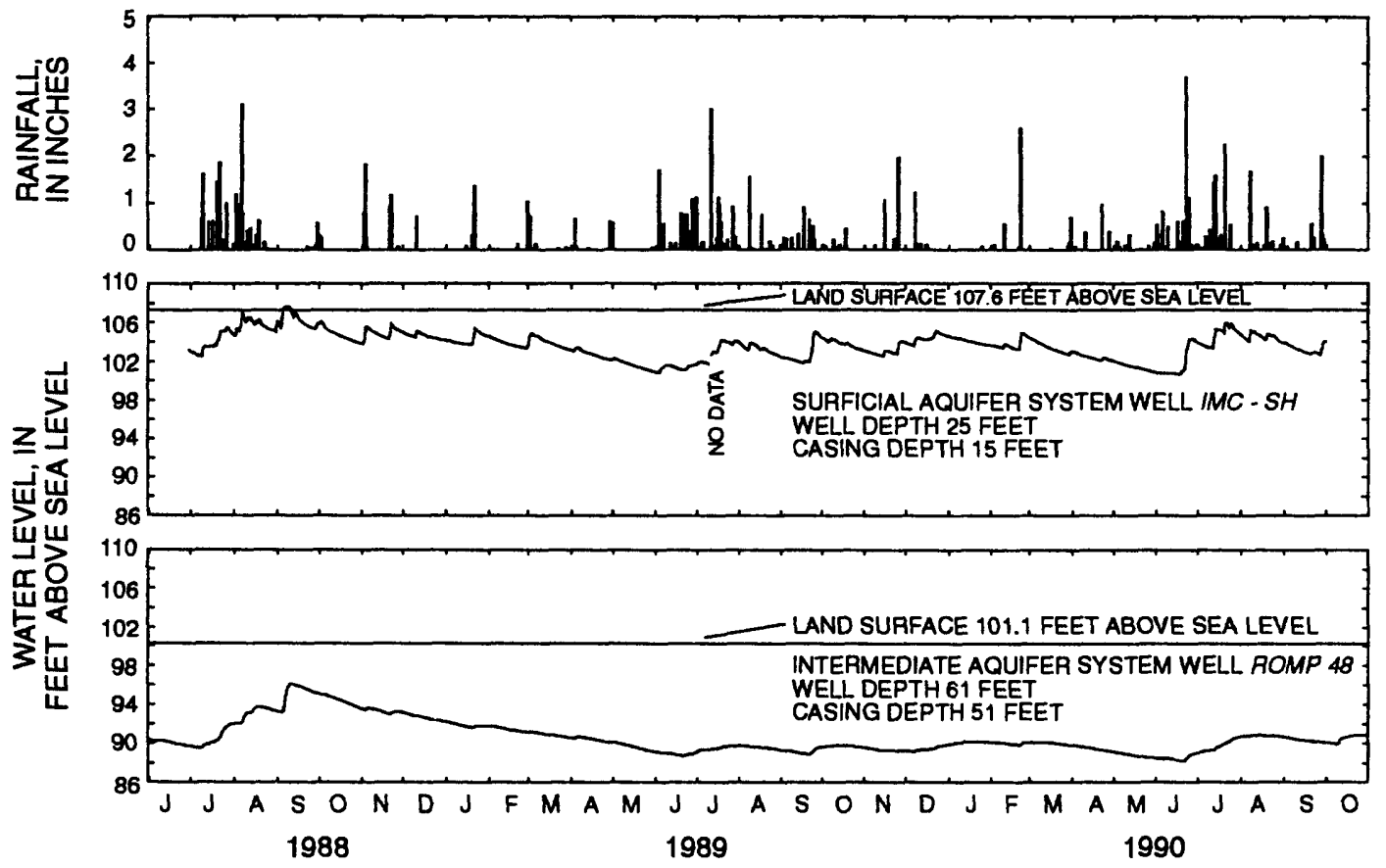

Figure 9. Daily rainfall and ground-water levels in monitor wells at the IMC Creek basin, June 1988 to October 1990.
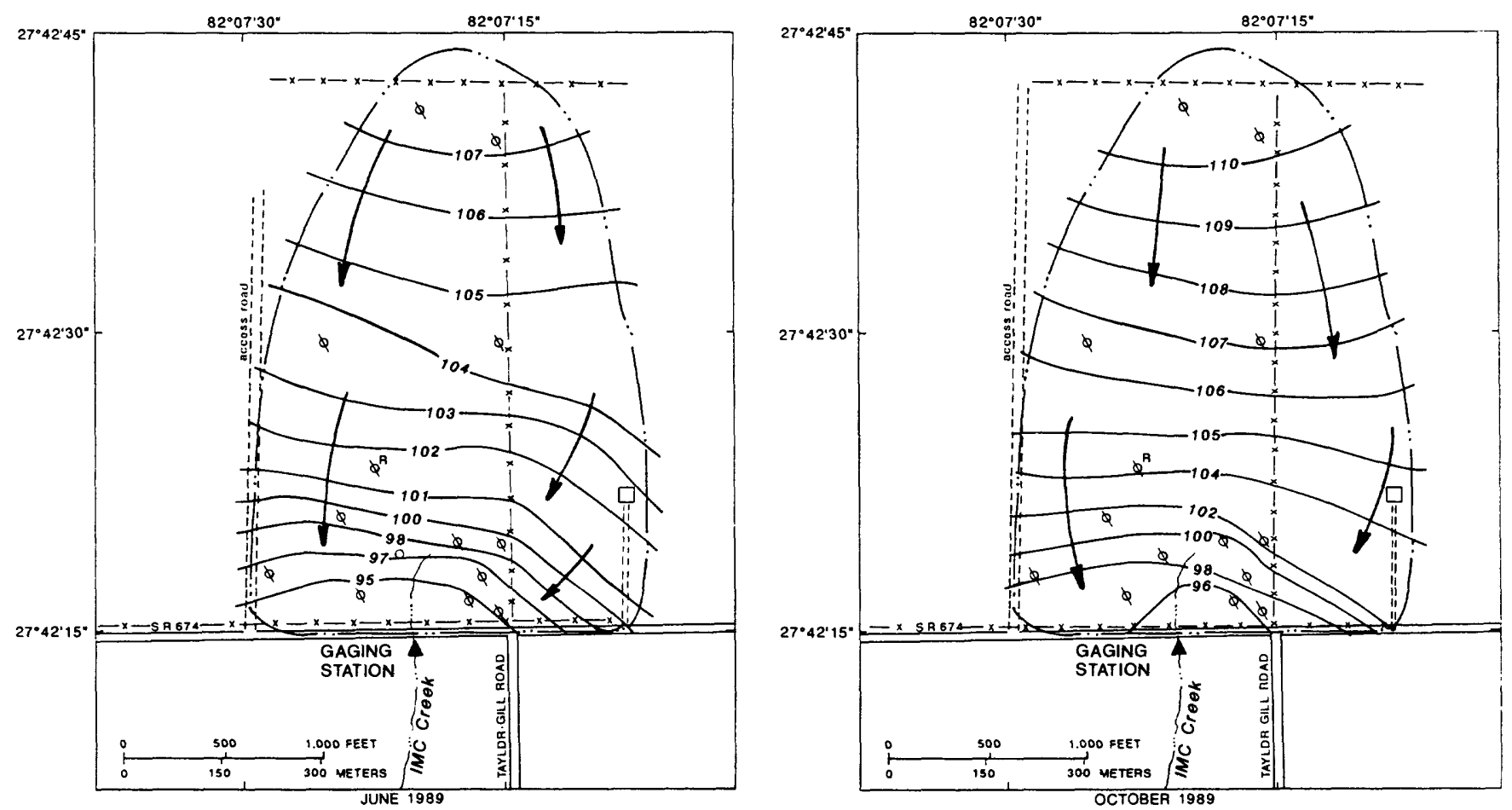

\section{EXPLANATION}

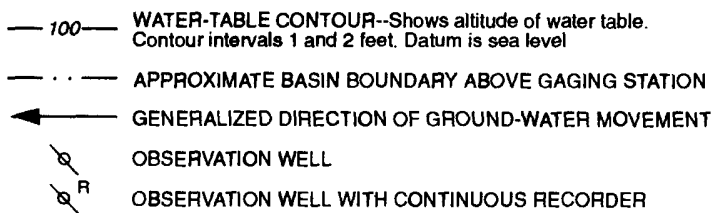

Figure 10. Configuration of the water table in the surficial aquifer system at the IMC Creek basin, June and October 1989. 


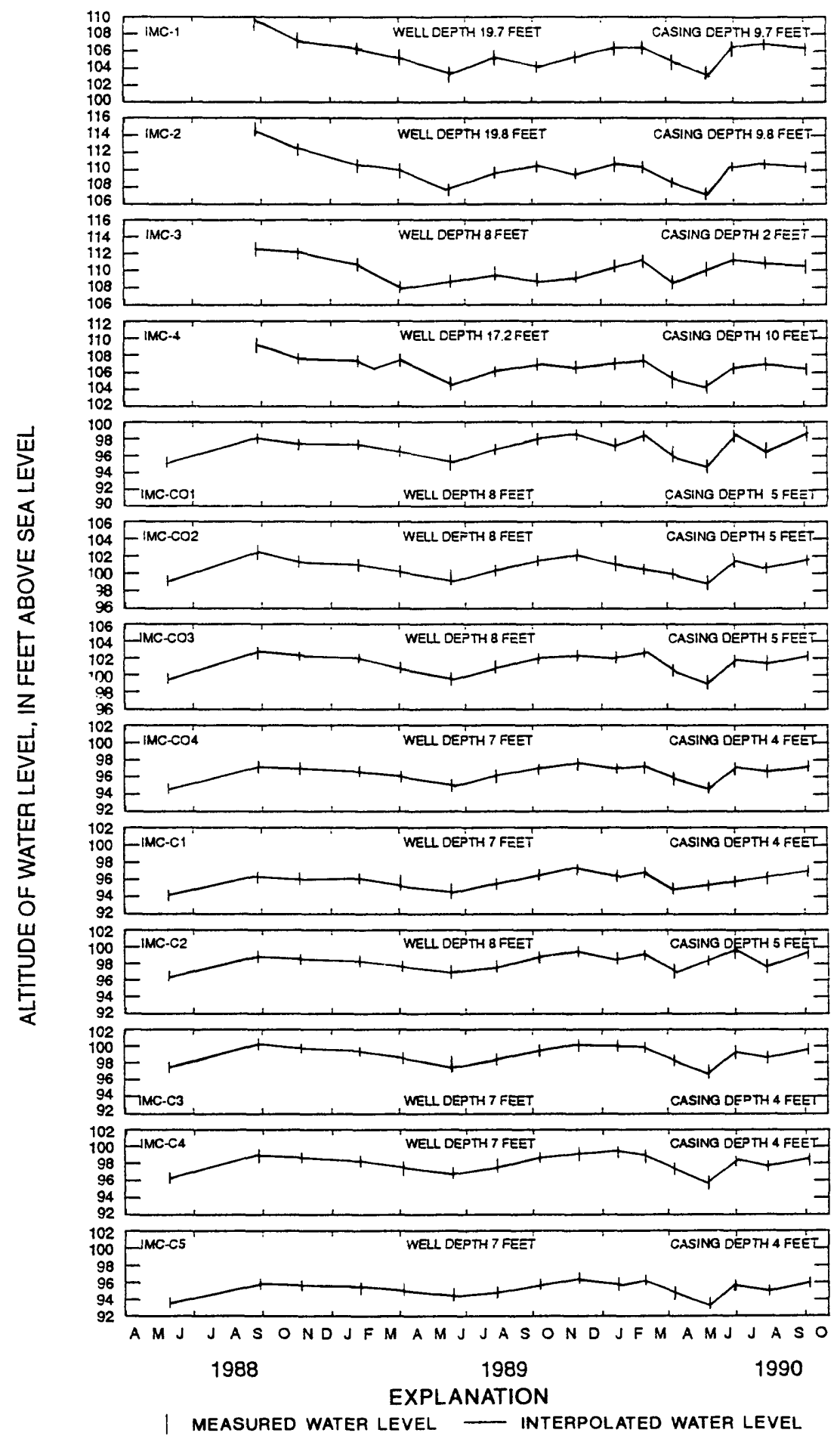

Figure 11. Water levels based on periodic measurements in wells completed in the surficial aquifer system, IMC Creek basin, June 1988 to October 1990 . 


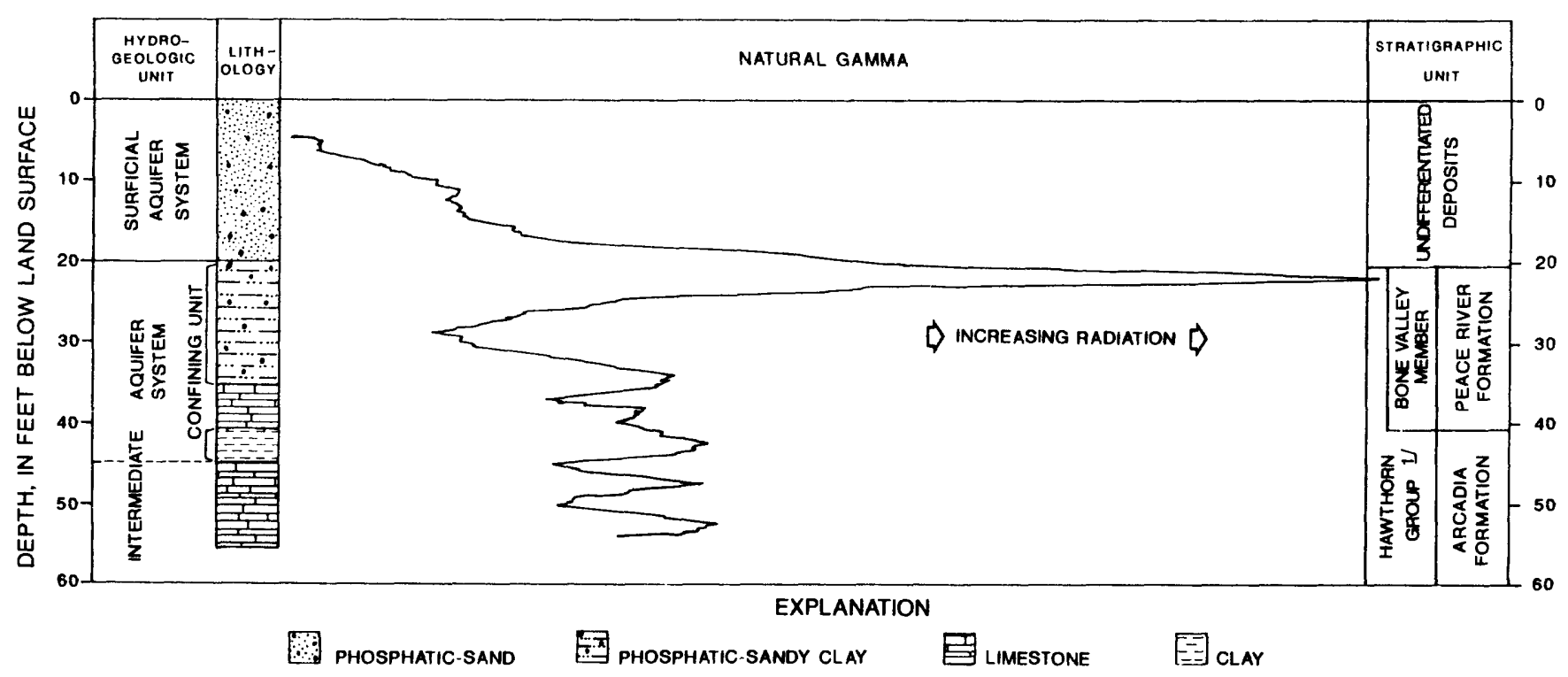

Figure 12. Hydrogeologic units, lithology, natural gamma-ray log, and stratigraphic units at well IMC-DP, completed in the intermediate aquifer system at the IMC Creek basin.

\section{Grace Creek}

Grace Creek basin is in southeastern Hillsborough County, about $3 \mathrm{mi}$ east of Fort Lonesome and $4 \mathrm{mi}$ west of the intersection of State Roads 674 and 37 . The northern boundary of the basin is about $1 \mathrm{mi}$ south of State Road 674 on Taylor Road (fig. 2). The unmined basin is roughly rectangular in shape (approximately $4,200 \mathrm{ft}$ wide by $4,400 \mathrm{ft}$ long) and is partially developed for agricultural use. The southern one-third of the basin is used for growing citrus; the remaining acreage is divided equally between pasture and wooded areas. The topography of the basin is flat and gently sloping; land surface ranges from approximately $140 \mathrm{ft}$ above sea level along the southern boundary to approximately $105 \mathrm{ft}$ above sea level at the gaging station (fig. 13). The gaged drainage area of the Grace Creek basin is about 420 acres $\left(0.66 \mathrm{mi}^{2}\right)$.

The main stream channel is about 7,200 ft in length, is generally well defined throughout the basin, and has a channel slope averaging $26 \mathrm{ft} / \mathrm{mi}$. The headwaters of the stream are in a pasture in the extreme southeastern part of the basin. From there, the stream flows northward and passes through a culvert at Taylor Road, a citrus grove, and another pasture. In the downstream reach of the channel, flows are toward the northwest through a heavily wooded area just upstream from the streamflow-gaging station (Grace Creek near Fort Lonesome).

The upper reach of Grace Creek remains dry except during periods of excessive rainfall. Except during periods of rainfall, flow is derived mostly from ground water. At times, runoff from an adjacent basin flows through a culvert under Taylor Road and into the study basin. An auxiliary streamflow-gaging station (Grace Tributary near Fort Lonesome) was established downstream from the culvert to monitor the streamflow from this tributary into Grace Creek. The adjusted discharge (Grace Creek discharge minus the tributary discharge) at the Grace Creek gaging station ranged from 0 to $47 \mathrm{ft}^{3} / \mathrm{s}\left(71.2\left(\mathrm{ft}^{3} / \mathrm{s}\right) / \mathrm{mi}^{2}\right)$.

Continuous water-level data for the surficial aquifer system in this basin were collected at a 25 -ft-deep well (Grace-SH well near Fort Lonesome). Water levels in this well ranged from $112.89 \mathrm{ft}$ above sea level $(0.30 \mathrm{ft}$ above land surface) in September 1988 to $107.33 \mathrm{ft}$ above sea level (5.32 ft below land surface) in June 1989 (fig. 14). Watertable maps show the seasonal configuration of the water table in the surficial aquifer system for June and October 1989 (fig. 15). These maps indicate the water level increased from 3 to $5 \mathrm{ft}$ between June and October, and the range of water-level change was consistent among the wells in the basin (fig. 16). Water-level fluctuations in these wells indicate recharge to the surficial aquifer system is by infiltration of rainfall. When the water levels are high, the shallow ground water is released from storage and is discharged to the stream channel during low-flow periods. Lithologic and gamma-ray logs from the Grace-DP well near Fort Lonesome indicate that the surficial aquifer system is about $20 \mathrm{ft}$ thick and overlies a $60-\mathrm{ft}$-thick layer of clay, sand, and limestone that forms the upper confining unit of the intermediate aquifer system (fig. 17). The hydraulic conductivity of the surficial aquifer system, computed from slug-recovery tests run at three Grace Creek wells, ranged from 2.20 to $17.9 \mathrm{ft} / \mathrm{d}$ (table 2).

Water levels monitored at a 90-ft-deep well (Grace-DP) indicate that the potentiometric surface of the intermediate aquifer system ranged from $108.14 \mathrm{ft}$ above sea level in September 1988 to $101.74 \mathrm{ft}$ above sea level in June 1989 (fig. 14). The potentiometric surface in the confined intermediate aquifer system averaged about $4 \mathrm{ft}$ lower than the water table in the unconfined surficial aquifer system . 


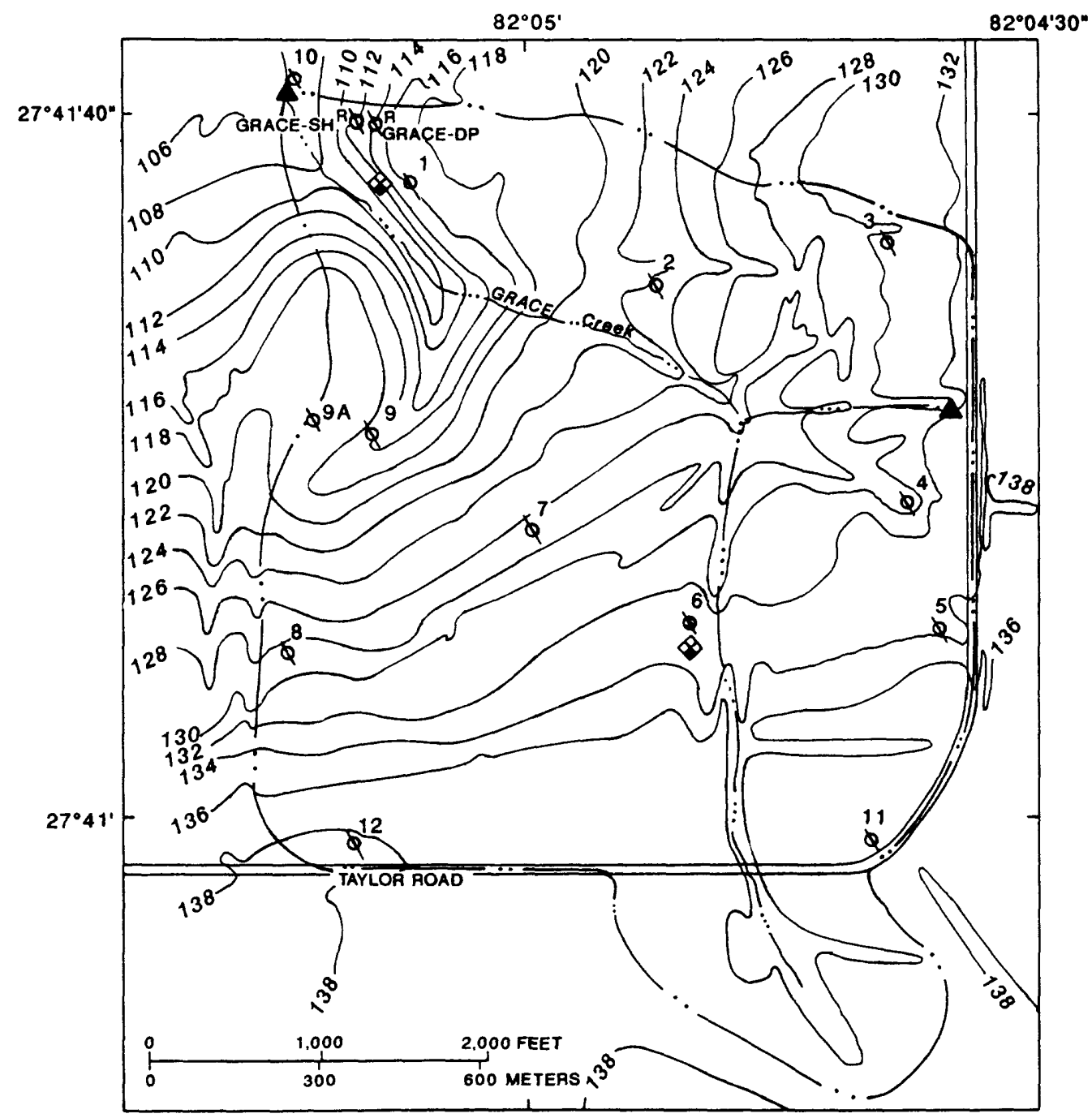

\section{EXPLANATION}

- 138- TOPOGRAPHIC CONTOUR--Shows altitude of land surface.

Contour interval 2 feet. Datum is sea level

- - APPROXIMATE BASIN BOUNDARY ABOVE GAGING STATION

$Q^{12}$ SURFICIAL AQUIFER SYSTEM WELL AND NUMBER

Q $Q^{R}$ GRACE-SH SURFICIAL AQUIFER SYSTEM WELL WITH CONTINUOUS RECORDER QRGRACE-DP INTERMEDIATE AQUIFER SYSTEM WELL WITH CONTINUOUS RECORDER

- StREAMFLOW GaGing Station

$\diamond$ RAINFALL RECORDING GAGE

Figure 13. Location of Grace Creek basin, topography, and data-collection network. 


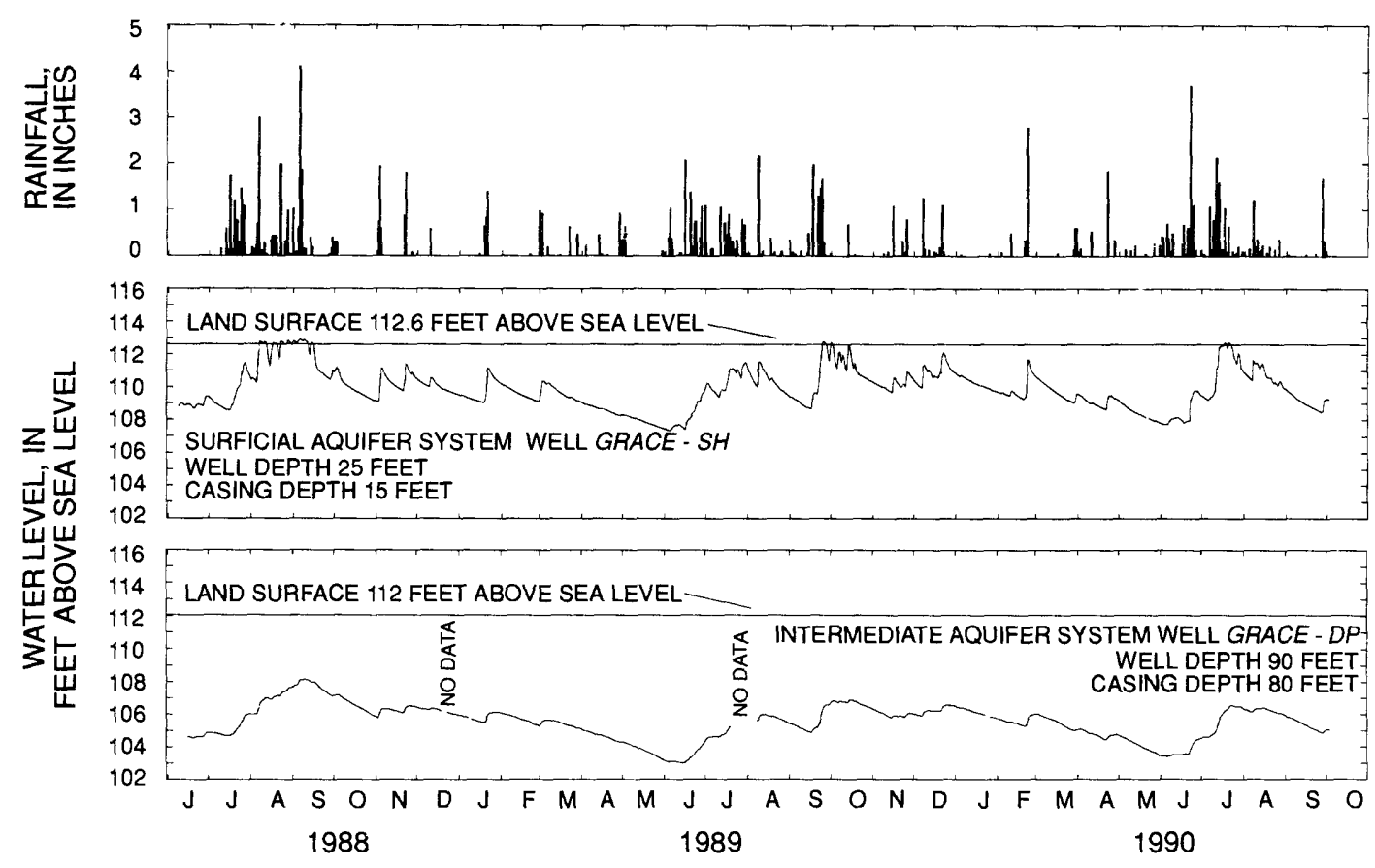

Figure 14. Daily rainfall and ground-water levels in monitor wells at the Grace Creek basin, June 1988 to October 1990.

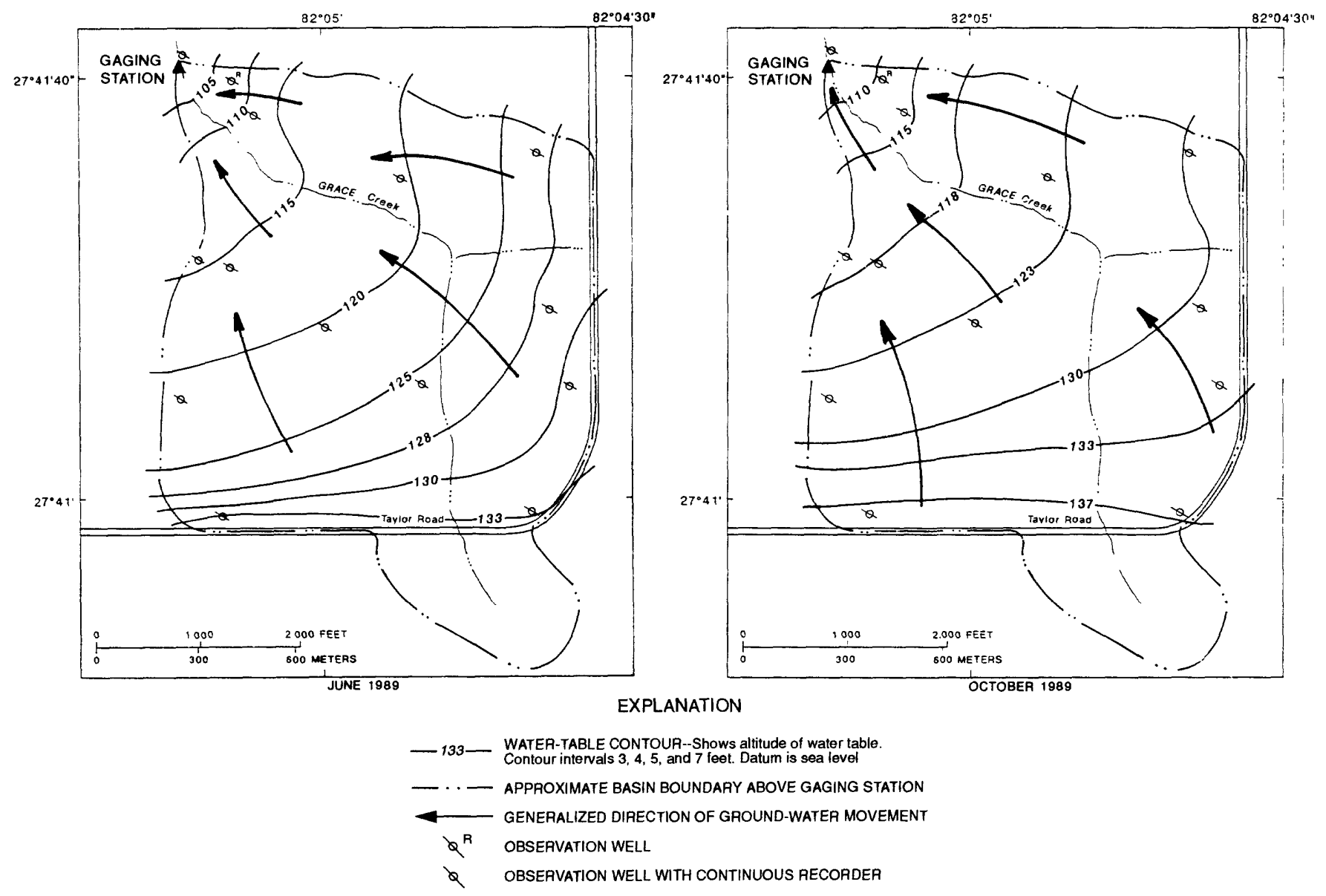

Figure 15. Configuration of the water table in the surficial aquifer system at the Grace Creek basin, June and October 1989. 


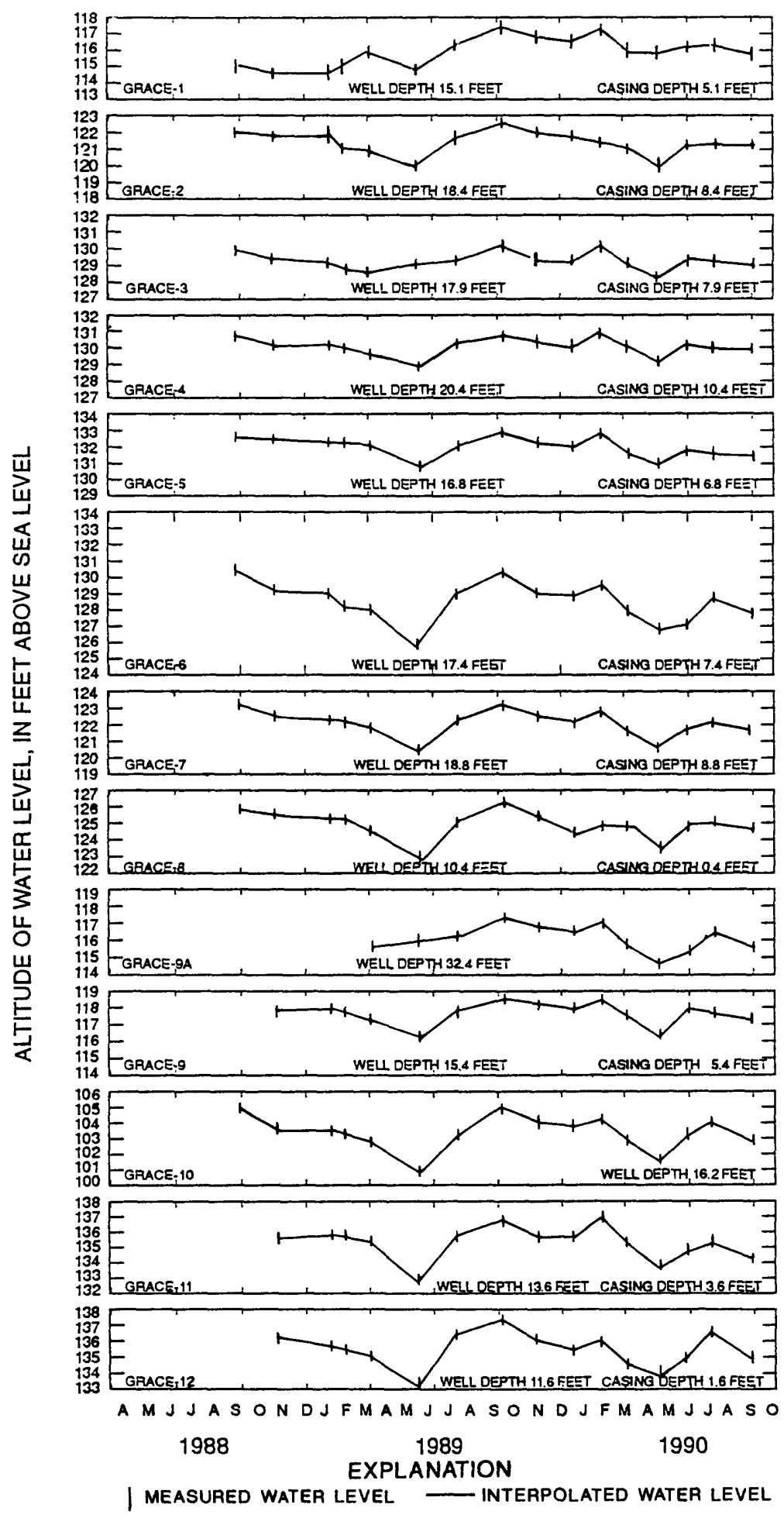

Figure 16. Water levels based on periodic measurements in wells completed in the surficial aquifer system, Grace Creek basin, September 1988 to October 1990. 


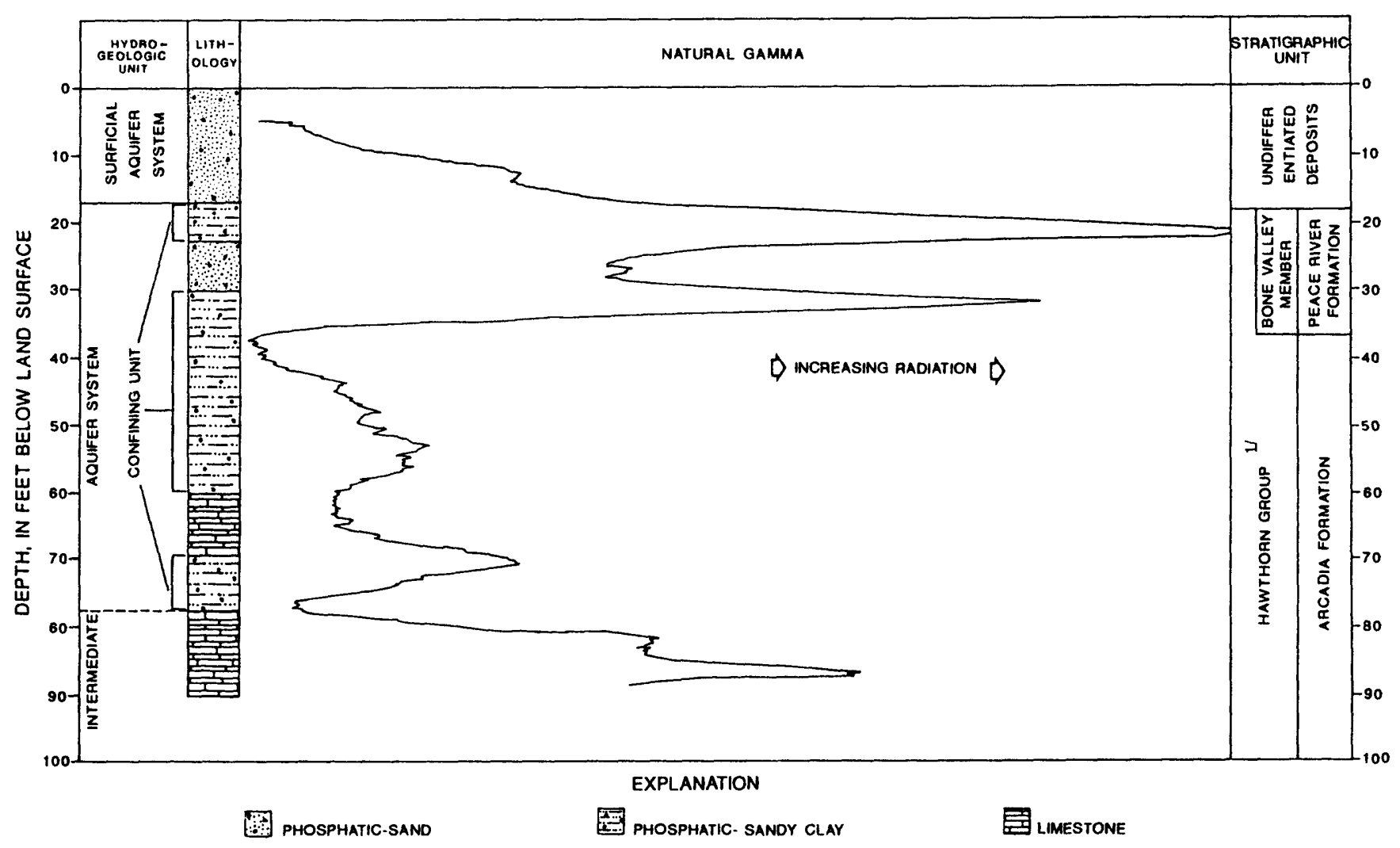

Figure 17. Hydrogeologic units, lithology, natural gamma-ray log, and stratigraphic units at well Grace-DP, completed in the intermediate aquifer system at the Grace Creek basin.

\section{CFI-3 Creek}

CFI-3 Creek basin is in northwestern Hardee County, $3 \mathrm{mi}$ northeast of Fort Green and $5 \mathrm{mi}$ west of Bowling Green (fig. 2). Open pasture covers approximately two-thirds of the basin; the remaining acreage is covered by palmetto scrub and forest. Land surface in the basin ranges from approximately $130 \mathrm{ft}$ above sea level along the northwestern boundary to approximately $115 \mathrm{ft}$ above sea level at the gaging station (fig. 18). The basin is approximately rectangular in shape $(2,200 \mathrm{ft}$ wide by $2,100 \mathrm{ft}$ long) and has a drainage area of about 90 acres $\left(0.14 \mathrm{mi}^{2}\right)$. The channel has an average slope of $36 \mathrm{ft} / \mathrm{mi}$ through the basin. The main channel is about $2,200 \mathrm{ft}$ in length and is well defined. The upper part of the basin is drained by a shallow ditch dug through the pasture, whereas the lower part of the basin drains naturally through a channel in a forested area just upstream from the streamflow-gaging station (CFI-3 Creek near Fort Green). Discharge at the gaging station ranged from 0 to $62.7 \mathrm{ft}^{3} / \mathrm{s}\left(448\left(\mathrm{ft}^{3} / \mathrm{s}\right) / \mathrm{mi}^{2}\right)$ during the study period.

Continuous water-level data for the surficial aquifer system in this basin were collected at a 25 -ft-deep well (CFI3-SH well near Fort Green). Water levels in this well ranged from $124.88 \mathrm{ft}$ above sea level $(0.14 \mathrm{ft}$ below land surface) in July 1989 to $118.88 \mathrm{ft}$ above sea level $(6.14 \mathrm{ft}$ below land surface) in June 1989 (fig. 19). Water-table maps based on water-level measurements in this well and in other wells show the seasonal fluctuation of the water table in the surficial aquifer system at low (June 1989) and high (December 1989) water-level periods (fig. 20). The direction of the ground-water flow generally is from west to east. Water-level data collected during periodic measurements at 12 observation wells in the basin are shown in figure 21 . The hydrograph for wells completed in the surficial aquifer system (fig. 21) shows the seasonal fluctuation caused by recharge from infiltration of rainfall, discharge to the stream channel when the water table is high, and movement of water to underlying aquifers. Lithologic and gamma-ray logs of the intermediate aquifer system well (CFI3-DP well near Fort Green) indicate that the surficial aquifer system is about $20 \mathrm{ft}$ thick and overlies a 64-ft-thick layer of clay, sand, and limestone that forms the upper confining unit of the intermediate aquifer system (fig. 22). The hydraulic conductivity of the surficial aquifer system computed from slug-recovery tests at three wells ranged from 0.1 to $3.2 \mathrm{ft} / \mathrm{d}$ (table 2).

Continuous water-level data for the intermediate aquifer system in this basin were collected at the CFI3-DP well. At this well, the potentiometric surface of the aquifer system ranged from $114.27 \mathrm{ft}$ above sea level in October 1990 to $111.56 \mathrm{ft}$ above sea level in June 1989. The potentiometric surface in the confined intermediate aquifer system averaged about $7 \mathrm{ft}$ lower than the water table in the unconfined surficial aquifer system. 


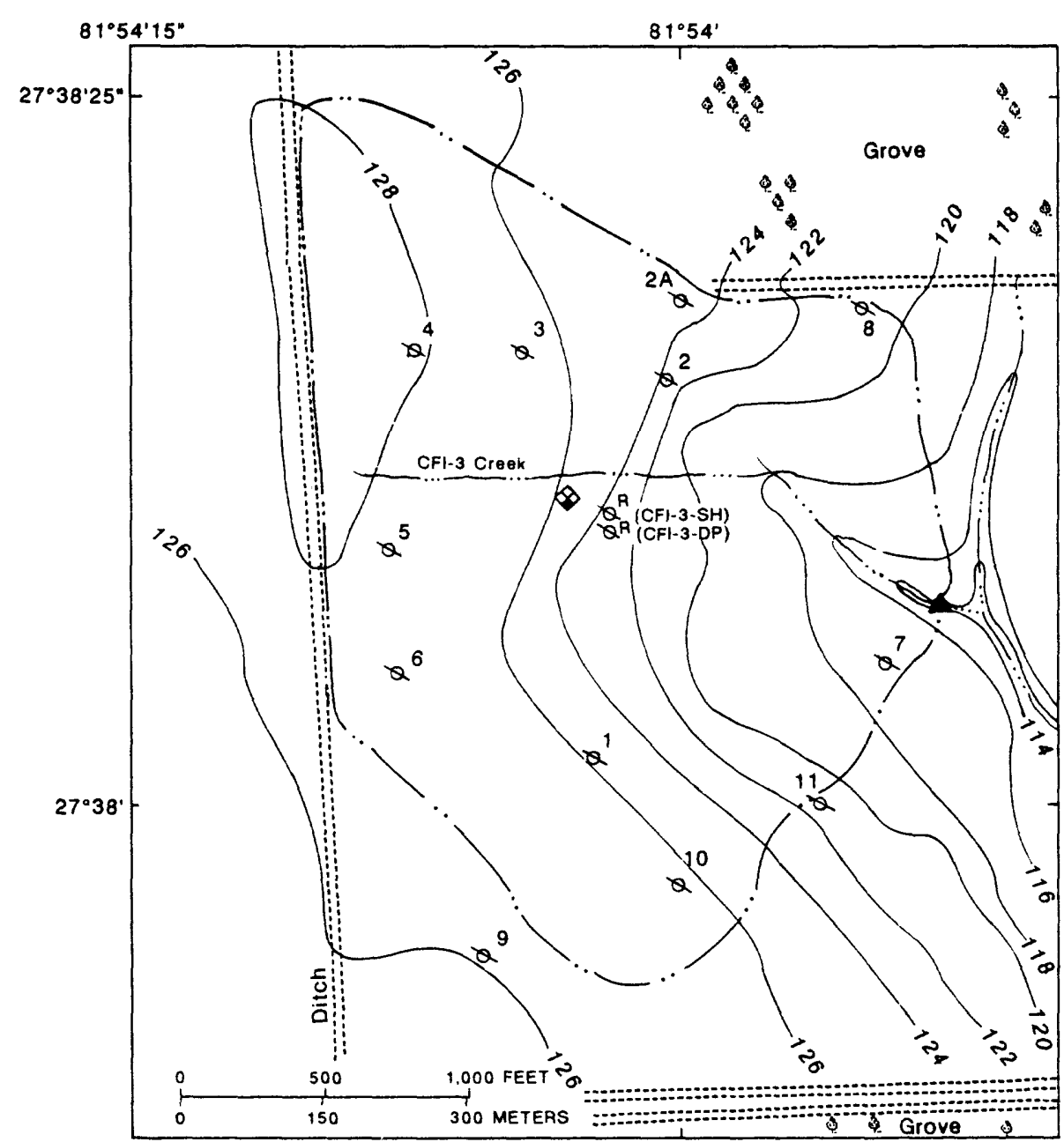

EXPLANATION

TOPOGRAPHIC CONTOUR--Shows altitude of land surface. Contour interval 2 feet.
Datum is sea level

— - APPROXIMATE BASIN BOUNDARY ABOVE GAGING STATION

$\gtrless^{9}$ SURFICIAL AQUIFER WELL AND SITE NUMBER

$Q^{R}$ (CFI-3-SH) SURFICIAL AQUIFER SYSTEM WELL WITH CONTINUOUS RECORDER

$Q^{R}$ (CFI-3-DP) INTERMEDIATE AQUIFER SYSTEM WELL WITH CONTINUOUS RECORDER

- STREAMFlow Gaging station

RAINFALL RECORDING GaGe

Figure 18. Location of CFI-3 Creek basin, topography, and data-collection network. 


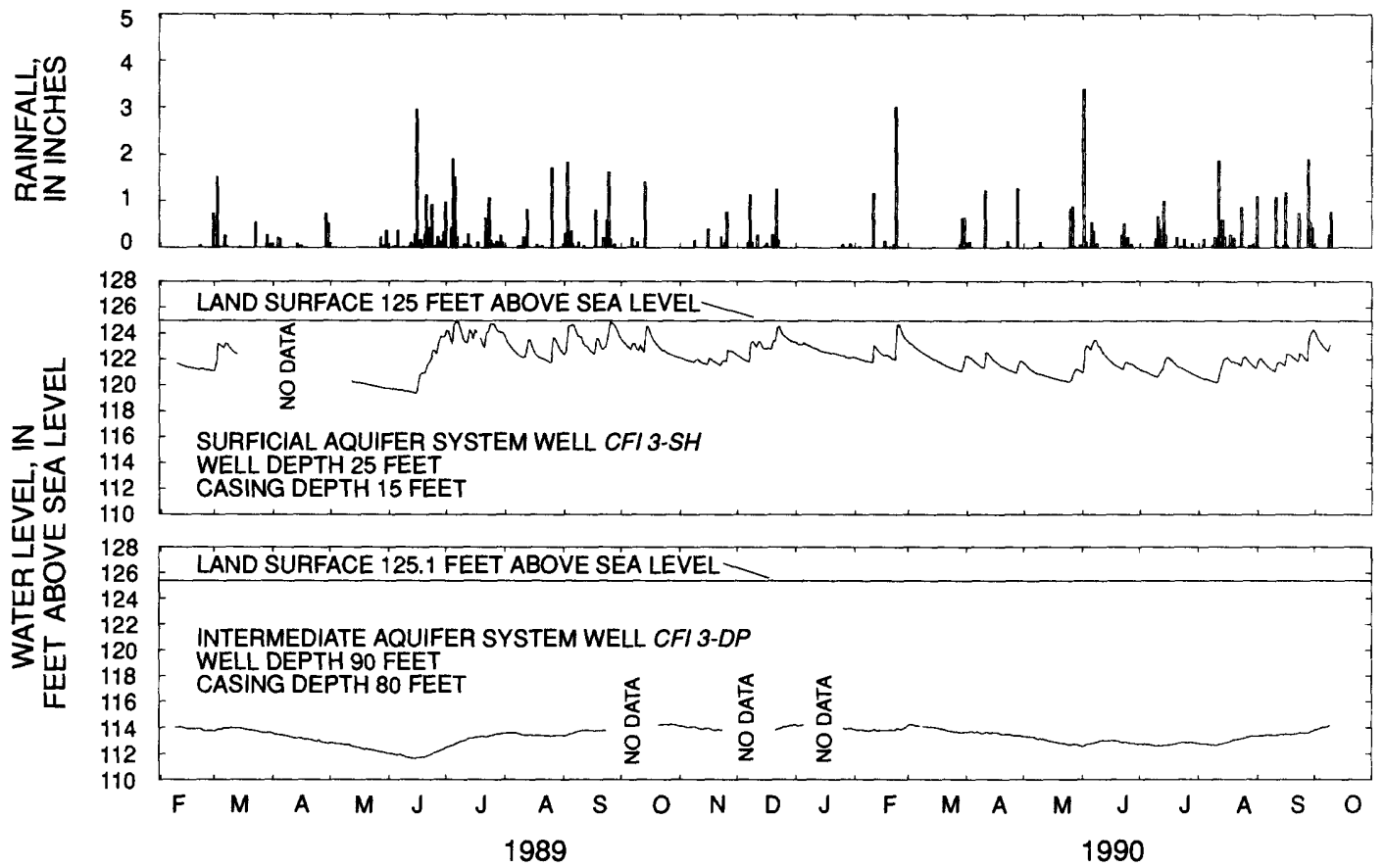

Figure 19. Daily rainfall and ground-water levels in monitor wells at the CFI-3 Creek basin, February 1989 to October 1990.
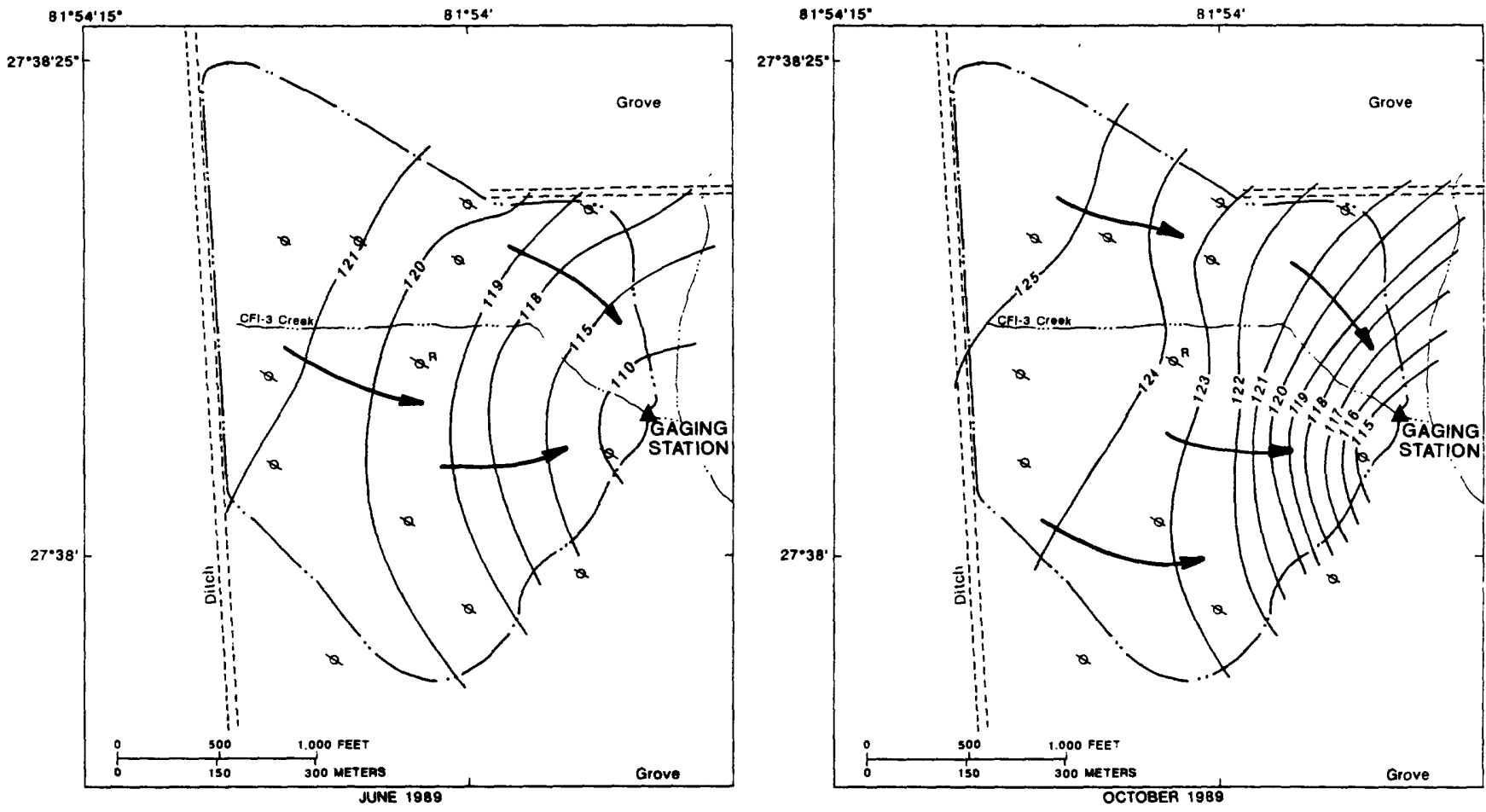

EXPLANATION

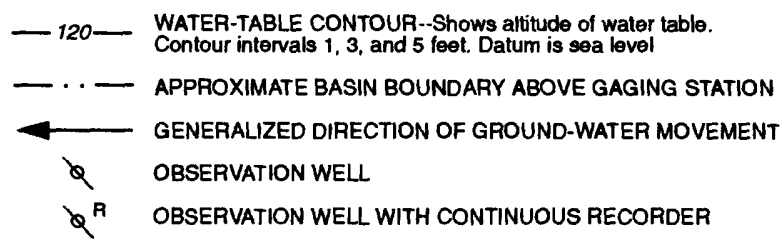

Figure 20. Configuration of the water table of the surficial aquifer system at the CFI-3 Creek basin, June and October 1989 . 


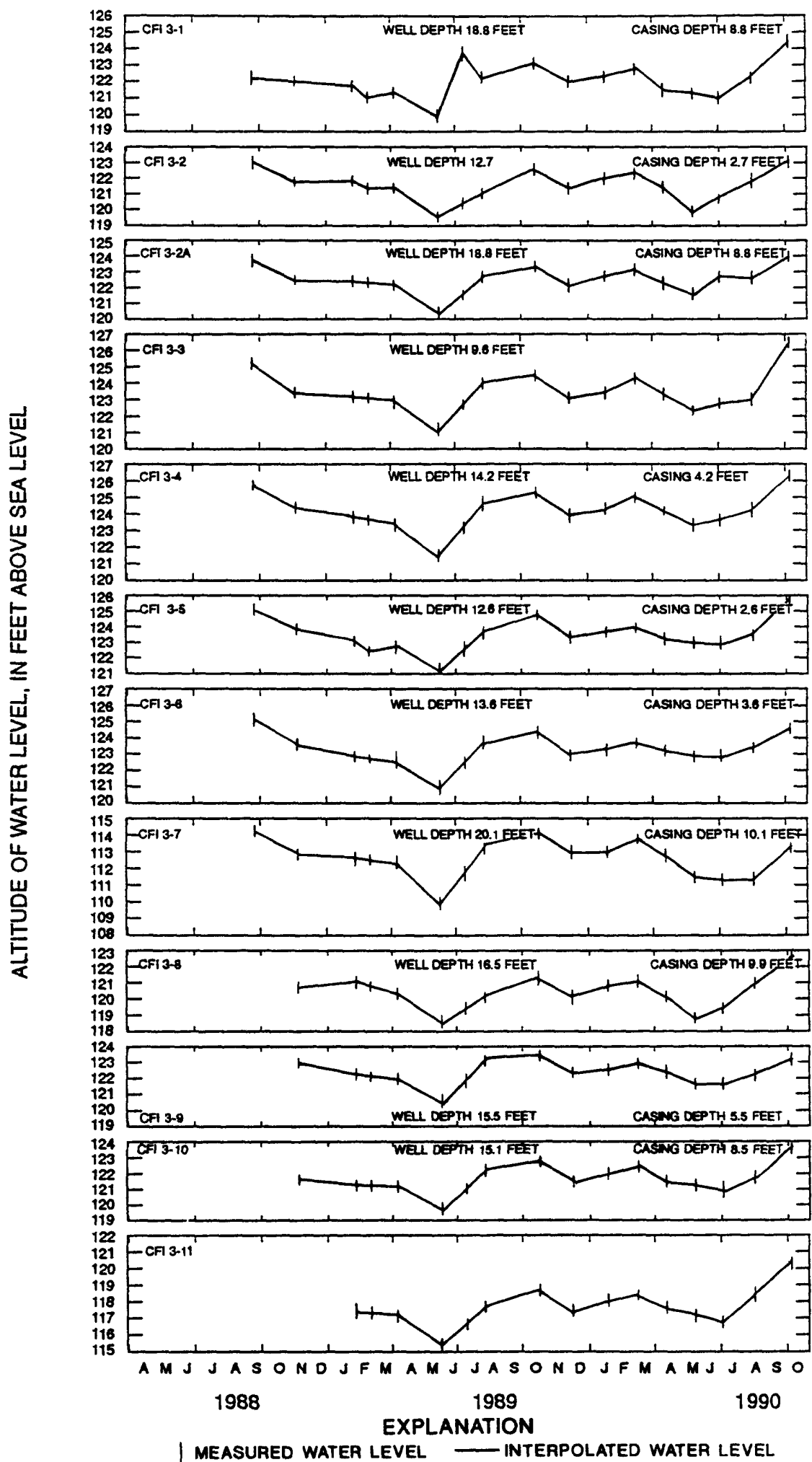

Figure 21. Water levels based on periodic measurements in wells completed in the surficial aquifer system, CFI-3 Creek basin, September 1988 to October 1990. 


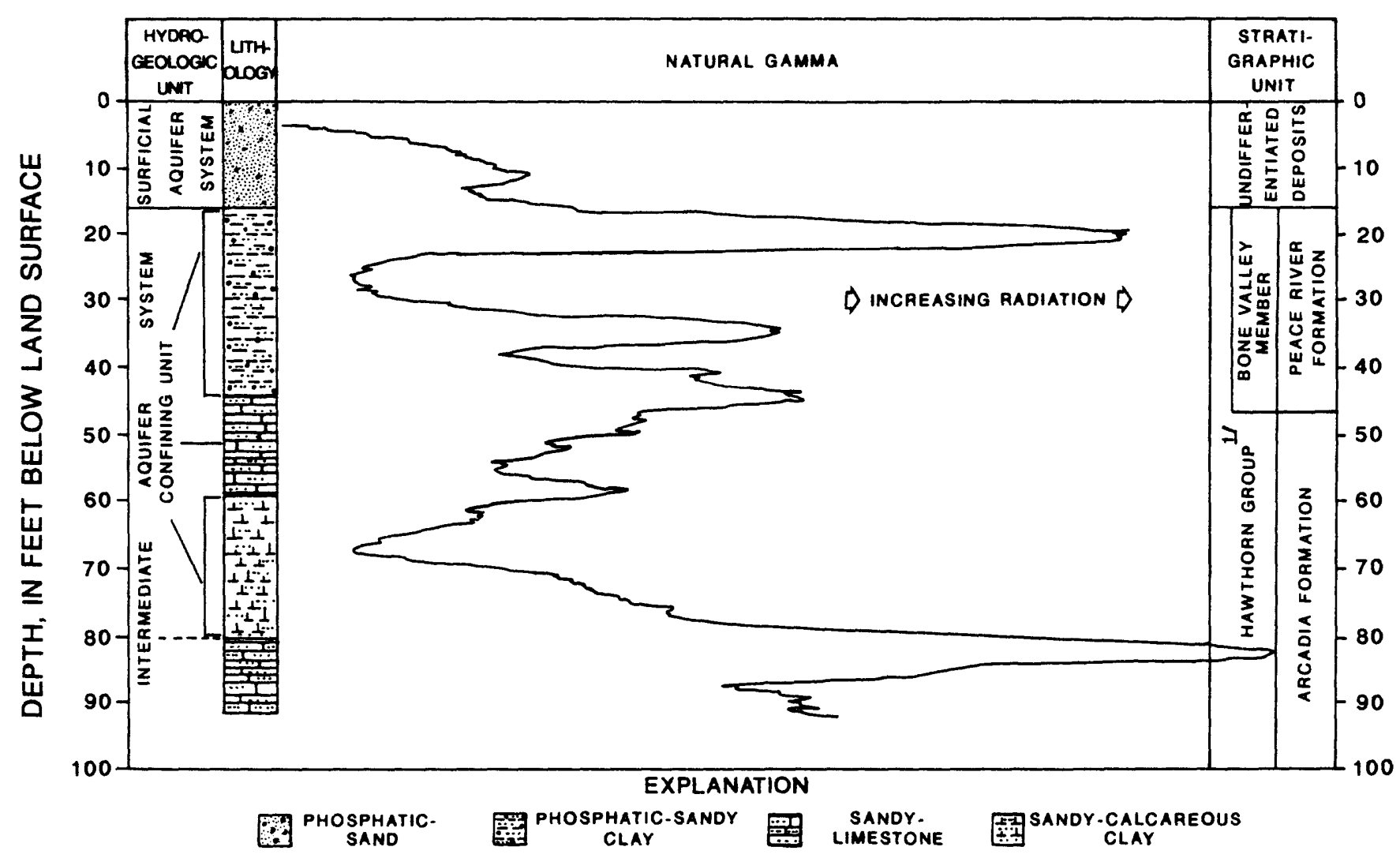

Figure 22. Hydrogeologic units, lithology, natural gamma-ray log, and stratigraphic units at well CFI3-DP, completed in the intermediate aquifer system at the CFI-3 Creek basin.

\section{DESCRIPTION AND HYDROLOGIC SETTING OF RECLAIMED BASINS}

Five small, reclaimed basins representing four unique methods of reclamation were selected for evaluation and comparison of hydrologic and water-quality characteristics with those of three unmined basins. The reclaimed basins include two clay-settling basins, a sand-clay settling basin, an overburden-capped sand-tailings basin, and a contouredoverburden basin. The clay-settling basins, Mobil Creek and Agrico-9 Creek, were selected for investigation because each basin represents a different developmental stage during reclamation. At the Mobil Creek basin, the entire thickness of the clay-fill material has become consolidated; at the Agrico-9 Creek basin, however, only the upper 5 to $6 \mathrm{ft}$ of the fill has become consolidated. The sand-clay settling basin, CFI-1 Creek, represents a recently developed method of reclamation that is used on a limited basis. The contoured-overburden method of reclamation used at the Agrico-1 Creek basin consists of grading and contouring the displaced onsite overburden only. For this type of reclamation, the altitude of the reclaimed land surface commonly is lower than that of the natural land surface because of the removal of the phosphate, sand, and clay matrix. The Agrico-4 Creek basin was reclaimed by the overburden-capped, sand-tailings method.
This method consists of backfilling the mined cuts with sand tailings and capping the sand tailings with material from the adjacent overburden pile.

\section{Mobil Creek}

Mobil Creek basin in southwestern Polk County, $2 \mathrm{mi}$ northeast of Fort Meade (fig. 2), has been reclaimed using the clay-settling method. The basin is gently sloping pasture with a small hummock of mature trees near the southeastern boundary. The land surface ranges from approximately $120 \mathrm{ft}$ above sea level along the northeastern boundary to approximately $100 \mathrm{ft}$ above sea level at the streamflow-gaging station (fig. 23). The basin is rectangular (approximately $1,200 \mathrm{ft}$ wide by $2,100 \mathrm{ft}$ long) and has an average slope of 50 $\mathrm{ft} / \mathrm{mi}$. The gaged drainage area of the Mobil Creek basin is about 47 acres $\left(0.07 \mathrm{mi}^{2}\right)$, and the main channel has an average slope of $23 \mathrm{ft} / \mathrm{mi}$.

Flow in Mobil Creek is intermittent. Runoff in the basin is highly responsive to rainfall because of the small drainage area, relatively steep slope, and the low permeability of the clay fill. The poorly defined stream channel is approximately $1,400 \mathrm{ft}$ in length and lies within a broad swale formed during reclamation. The channel begins at the 
south-central boundary of the basin and drains northward to the center where it abruptly turns west to the streamflowgaging station (Mobil Creek near Fort Meade). Discharge at the gaging station ranged from 0 to $35 \mathrm{ft}^{3} / \mathrm{s}\left(500\left(\mathrm{ft}^{3} / \mathrm{s}\right) / \mathrm{mi}^{2}\right)$ during this study.

In most of the Mobil Creek basin, the undifferentiated clastic deposits that constitute the surficial aquifer system have been removed by strip mining, and the clay fraction of the phosphate matrix separated during the beneficiation process has been redeposited in the mined area. This clay has consolidated into a thick, plastic layer with low permeability. The hydraulic conductivity computed from slug-recovery tests of this clay material ranged from less than 0.01 to $0.4 \mathrm{ft} / \mathrm{d}$ at three Mobil Creek wells (table 2). Lithologic and gamma-ray logs of an intermediate aquifer system well (MBL-DP well near Fort Meade) in the basin indicate that the clay generally extends from land surface to the top of the carbonate deposits of the intermediate aquifer system (fig. 24).

Continuous water-level data for the surficial aquifer system in this basin were collected at a 25 -ft-deep well (MBL-SH well near Fort Meade). Water levels in the surficial aquifer system at this well ranged from $93.03 \mathrm{ft}$ above sea level ( $8.67 \mathrm{ft}$ below land surface) in August 1990 to $88.34 \mathrm{ft}$ above sea level (13.36 ft below land surface) in June 1990, and the average depth to the water table was about $10 \mathrm{ft}$ during this study (fig. 25). Water-table maps of the surficial aquifer system indicate that seasonal variations in groundwater levels in the aquifer averaged about $1 \mathrm{ft}$, as shown by

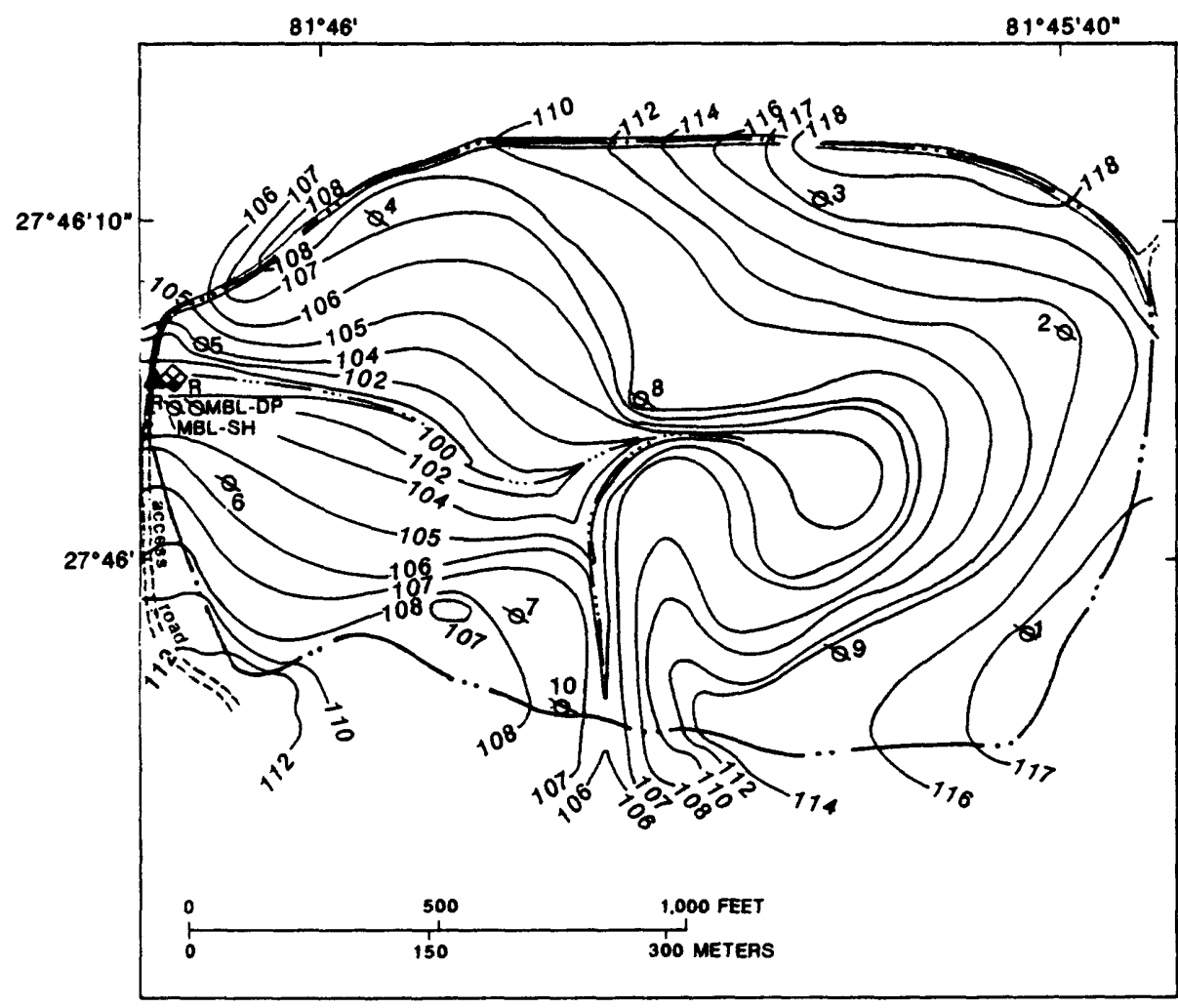

EXPLANATION

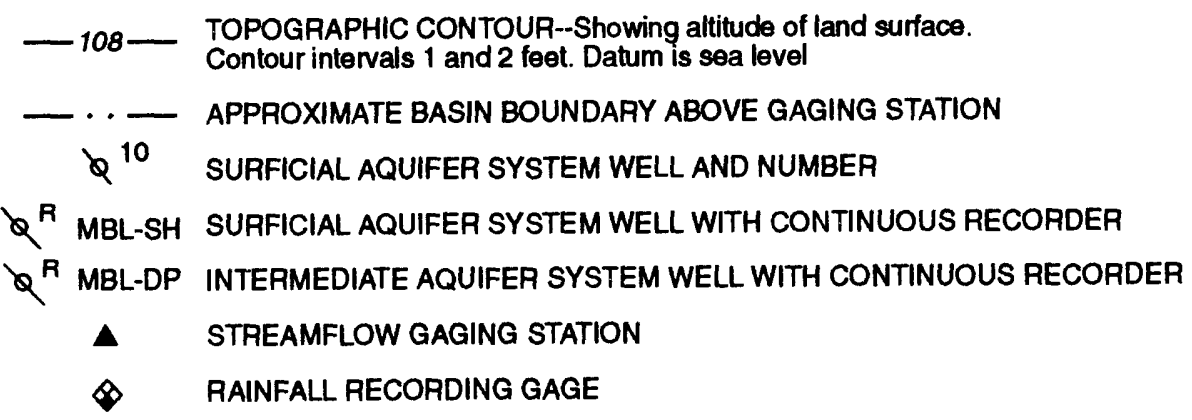

Figure 23. Location of the Mobil Creek basin, topography, and data-collection network. 


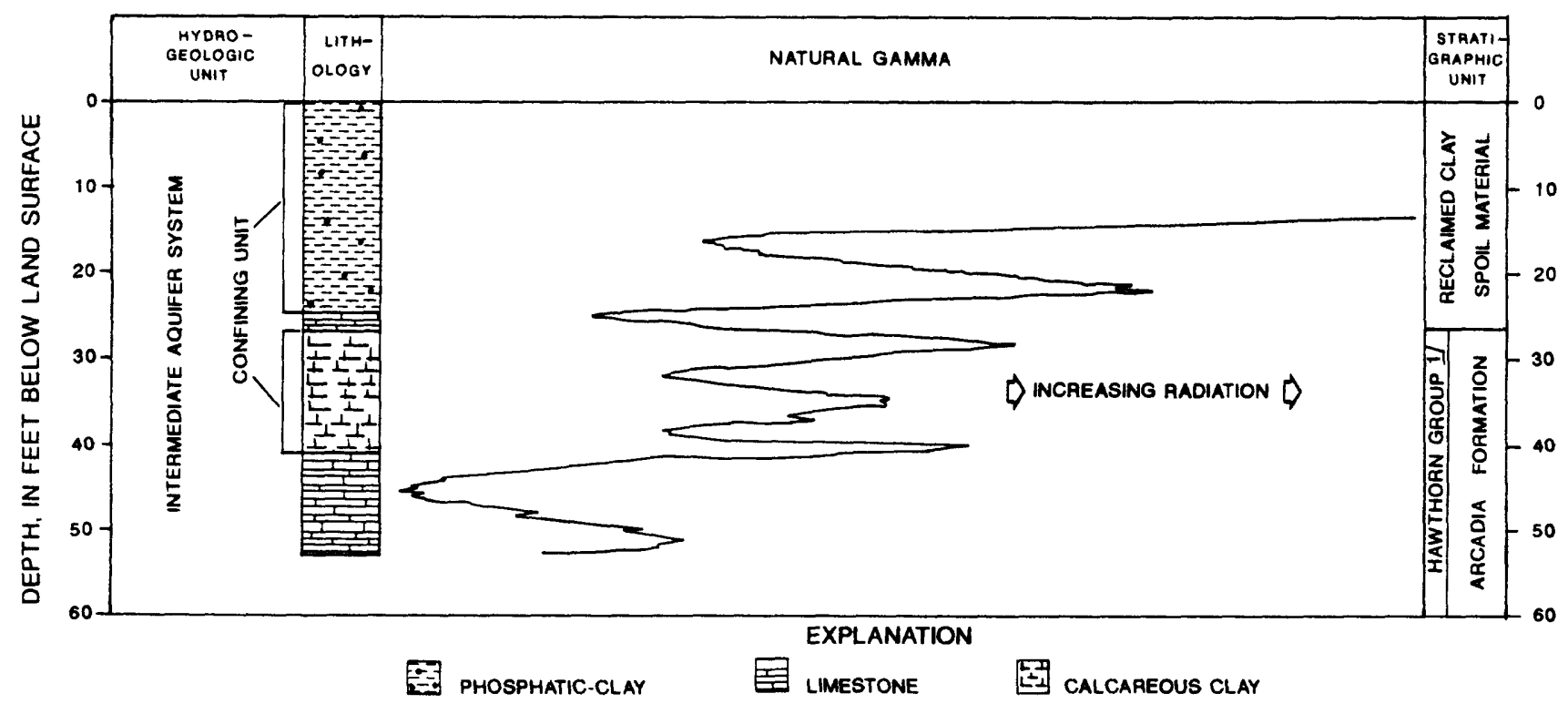

Figure 24. Hydrogeologic units, lithology, natural gamma-ray log, and stratigraphic units at well MBL-DP, completed in the intermediate aquifer system at the Mobil-3 Creek basin.

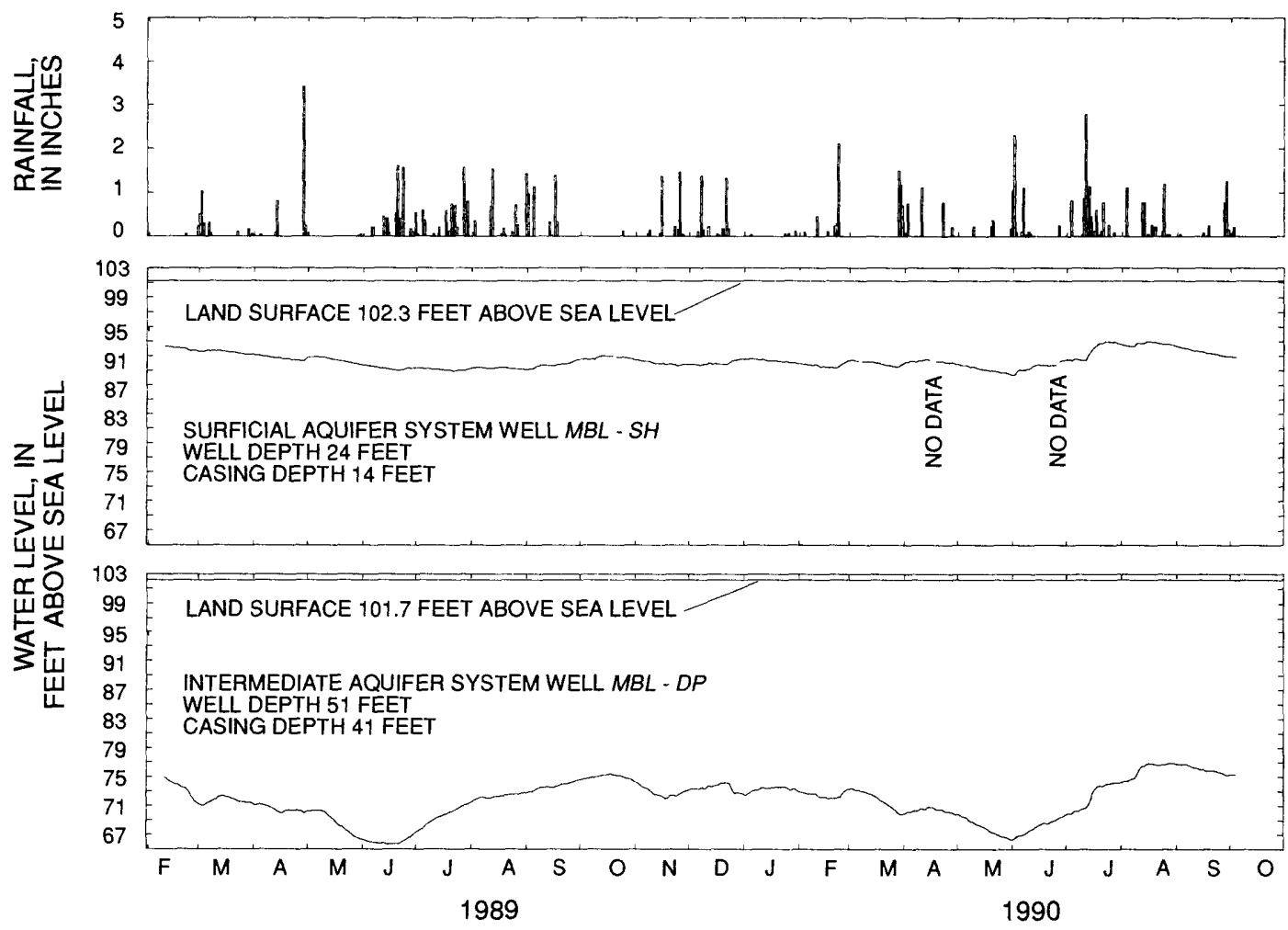

Figure 25. Daily rainfall and ground-water levels in monitor wells at Mobil Creek basin, February 1989 to October 1990. 


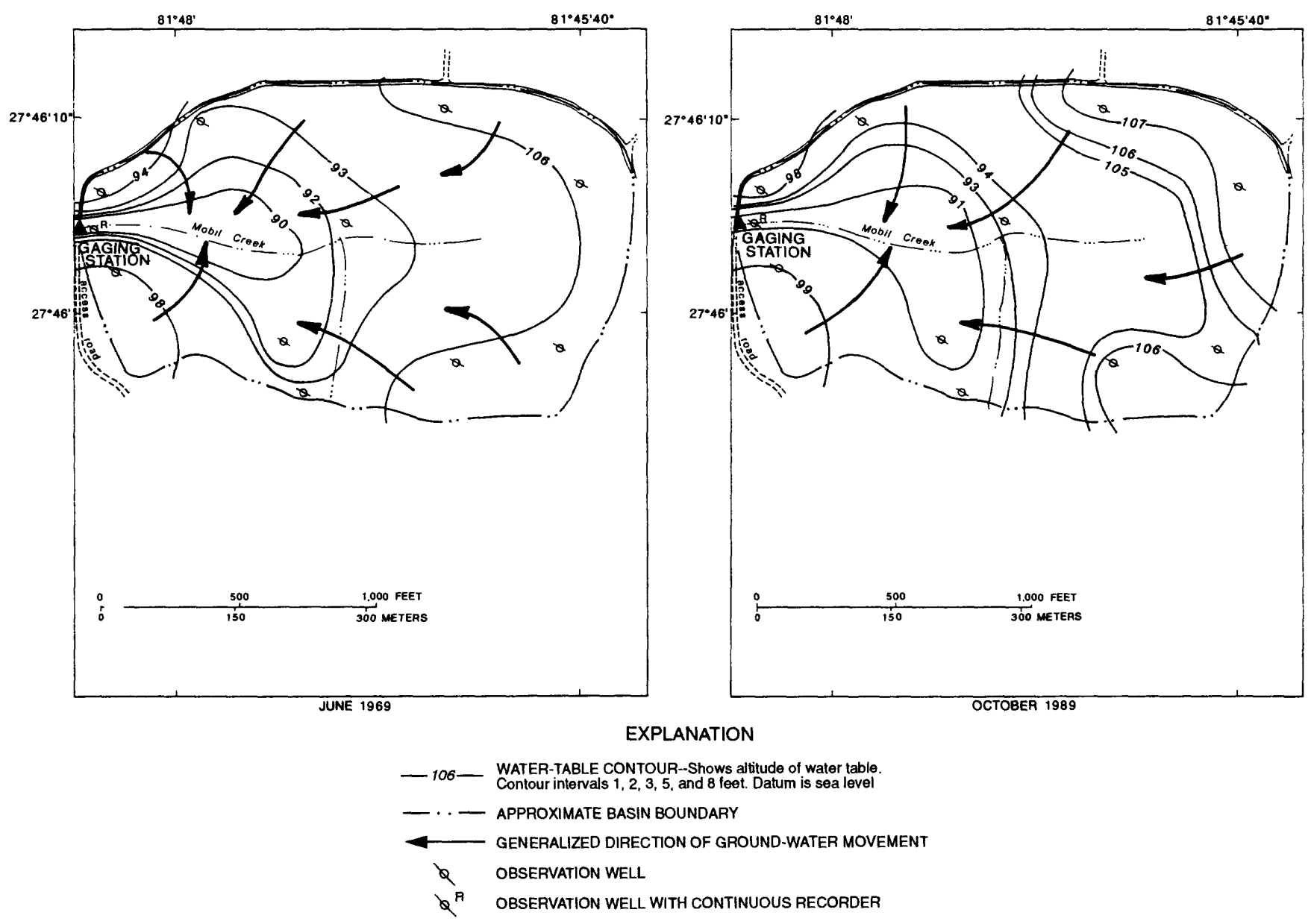

Figure 26. Configuration of the water table in the surficial aquifer system at the Mobil Creek basin, June and October 1989.

measurements in June and October 1989 (fig. 26). Periodic water-level measurements in 10 observation wells in this basin indicate that water levels responded slowly to seasonal fluctuations in rainfall (fig. 27).

Continuous water-level data for the intermediate aquifer system collected at a 52-ft-deep well (MBL-DP) indicate that the potentiometric surface of this aquifer in the Mobil Creek basin ranged from $76.90 \mathrm{ft}$ above sea level in August 1990 to $65.53 \mathrm{ft}$ above sea level in June 1989 (fig. 25). The potentiometric surface of the intermediate aquifer system in this well ranged seasonally from 15 to $24 \mathrm{ft}$ lower than the water table in the surficial aquifer system. Water-level fluctuations in the intermediate aquifer system followed seasonal trends similar to those in the surficial aquifer system.

\section{Agrico-9 Creek}

The Agrico-9 Creek basin in southwestern Polk County, $7.5 \mathrm{mi}$ east of Fort Lonesome (fig. 2), has been reclaimed using the clay-settling method. The basin is enclosed by a dike that was used to contain the suspended clay material during filling. After the basin was filled with the clay slurry, the clay was allowed to settle and the surface water was drained. A thick clay crust formed as the clay dried. The basin is covered by pasture with a dense population of willow trees growing along the banks of the main channel of Agrico-9 Creek. As part of an experimental agricultural project undertaken by Polk County, several acres in the northern part of the basin have been cultivated to determine suitability of the clay soil for a variety of row crops and native trees. Land surface in the basin ranges from approximately $158 \mathrm{ft}$ above sea level along the southeastern boundary to approximately $130 \mathrm{ft}$ above sea level at the gaging station. The topography exhibits an undulating pattern caused by dehydration and consolidation of clays in the mine cuts between the rows of overburden spoil piles. The Agrico- 9 Creek basin is rhomboid in shape (approximately $3,000 \mathrm{ft}$ wide by $4,000 \mathrm{ft}$ long) and has an average slope of $26 \mathrm{ft} / \mathrm{mi}$. The gaged drainage area of the basin is 250 acres $\left(0.39 \mathrm{mi}^{2}\right)$.

Streamflow from the Agrico-9 Creek basin is intermittent. The impervious clay material restricts infiltration of rainfall, which results in rapid surface runoff; however, runoff collects in numerous surface depressions in the basin resulting in attenuated peak discharges at the gaging station (fig. 28). The main channel of the creek extends about one-half the width 


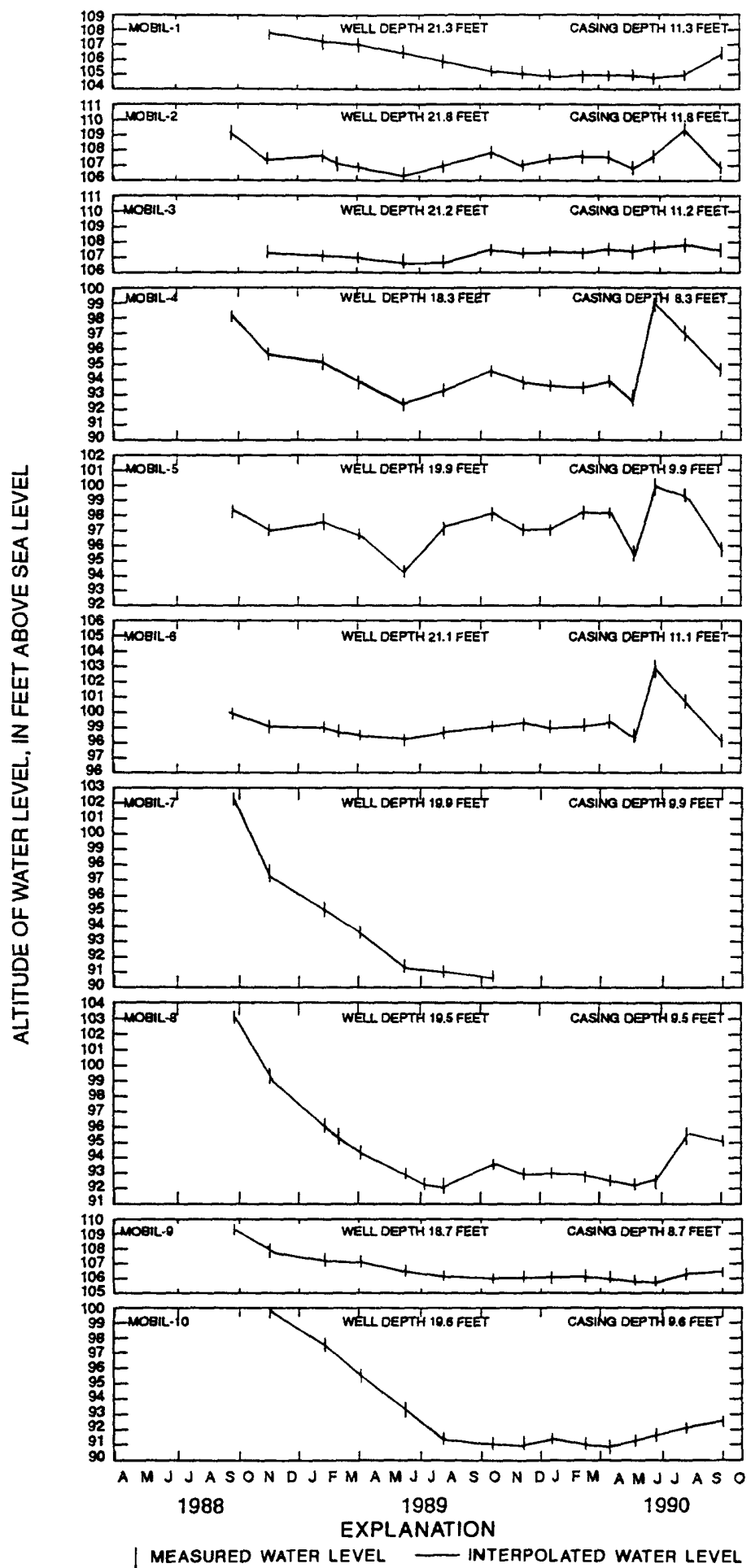

Figure 27. Water levels based on periodic measurements in wells completed in the surficial aquifer system, Mobil Creek basin, September 1988 to October 1990. 


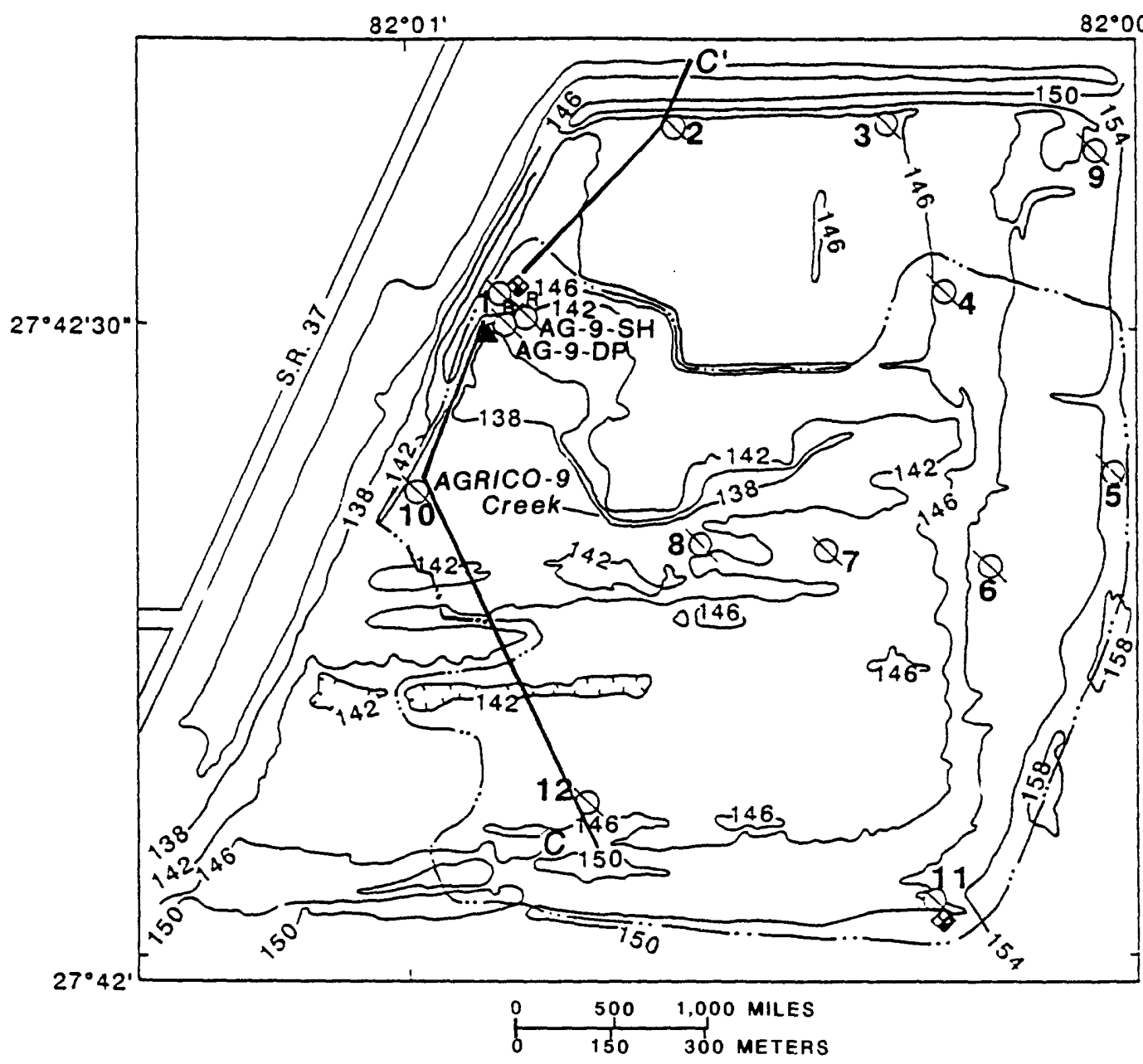

\section{EXPLANATION}

-144- TOPOGRAPHIC CONTOUR--Showing altitude of land surface. Contour interval 4 feet. Datum is sea level

APPROXIMATE BASIN BOUNDARY ABOVE GAGING STATION

$C-C^{\prime} \quad$ LINE OF GENERALIZED HYDROGEOLOGIC SECTION

$12 Q$ SURFICIAL AQUIFER SYSTEM WELL AND NUMBER

$Q^{R}$ AG-9-SH SURFICIAL AQUIFER SYSTEM WELL WITH CONTINUOUS RECORDER

$Q^{R}$ AG-9-DP INTERMEDIATE AQUIFER SYSTEM WELL WITH CONTINUOUS RECORDER

\section{- StREAMFlow gaging station \\ RAINFALL RECORDING GaGE}

Figure 28. Location of Agrico-9 Creek basin, topography, data-collection network, and line of hydrogeologic section $C-C^{\prime}$. 
of the basin upstream from the gaging station (Agrico-9 Creek near Fort Lonesome). The main channel is connected to a network of ditches that were cut to facilitate surface drainage and dehydration of the clay. Downstream from the gaging station, flow from Agrico-9 Creek discharges through a culvert under the dike and empties into a large recirculation canal. The canal causes permanent backwater at the gaging station that prevented use of a standard stage-discharge relation to determine streamflow. An electromagnetic velocity meter was used to compute streamflow. However, collection of streamflow records was limited by periodic low stages in the recirculation canal that exposed the velocity meter. Discharge at the gaging station ranged from 0 to $5.6 \mathrm{ft}^{3} / \mathrm{s}$ $\left(14.4\left(\mathrm{ft}^{3} / \mathrm{s}\right) / \mathrm{mi}^{2}\right)$.

The surficial aquifer system was altered during mining operations at the Agrico-9 Creek basin when the overburden was stripped and placed in adjacent mined-out cuts. Fourteen rows of spoil piles were formed at the site and each pile averaged about $40 \mathrm{ft}$ in height and about two-thirds of a mile in length. A dike was constructed at the perimeter of the basin during reclamation to create an impoundment into which the clay fraction of the phosphate matrix was pumped as a slurry. The clay accumulated over a period of time to fill the mined cuts and to cover the tops of the overburden spoil piles (fig. 29). Slurry water was drained off from the impoundment area as the clay settled, and a clay crust several feet thick formed as the clay dried. The degree of consolidation of the clay crust varies with depth and time, but the clay below the crust remains viscous. The clay covering the overburden piles varies in thickness from less than $1 \mathrm{ft}$ to more than $40 \mathrm{ft}$. The hydraulic conductivity of the surficial aquifer system was determined from recovery tests performed in the upper 17 to $20 \mathrm{ft}$ of clay and overburden and was computed to be 0.8 and $1.2 \mathrm{ft} / \mathrm{d}$ from two Agrico-9 Creek wells (table 2). Recharge from the infiltration of rainfall to the aquifer is restricted by the less permeable upper clay layer. Lithologic and gamma-ray logs of the surficial aquifer system at well AG9-DP near Fort Lonesome indicate that the clay at that site is about $15 \mathrm{ft}$ thick and overlies a 25 -ft-thick layer of overburden (fig. 30).

Continuous water-level data for the surficial aquifer system in this basin were collected at a 24-ft-deep well (AG9-SH well near Fort Lonesome). Water levels in this well ranged from $129.90 \mathrm{ft}$ above sea level $(3.92 \mathrm{ft}$ below land surface) in July 1990 to $127.34 \mathrm{ft}$ above sea level $(6.48 \mathrm{ft}$ below land surface) in June 1989 (fig. 31). Water-table maps based on water-level measurements in this well and 12 observation wells in the area during the low (June 1989) and high (August 1989) water-level periods (fig. 32) indicate that the direction of ground-water flow is predominantly from the southeast to the northwest. Water-level fluctuations in the 12 observation wells indicate consistent seasonal trends (fig. 33). Water-level changes in well AG9-SH indicate a delayed, but similar, response to recharge from rainfall as was observed at the unmined basins. This delayed response is attributed to the setting of the well screen into the more permeable overburden underlying the clay. The screened intervals of the 12 observation wells in the area of the Agrico-9 Creek basin were set in either clay, overburden, or both, depending upon the location of the well. The screened interval of wells 2, 3, 4, and 9 were set in unmined strata that was covered by 3 to $4 \mathrm{ft}$ of clay fill. Water-level fluctuations in these wells generally were greater than those in wells that were placed in mined areas (figs. 28-29).

Continuous water-level data for the intermediate aquifer system in the Agrico-9 Creek basin were collected at a 70-ft-deep well (AG9-DP). The potentiometric surface at this well ranged from $130.43 \mathrm{ft}$ above sea level in September 1988 to $126.56 \mathrm{ft}$ above sea level in June 1989 (fig. 31). The potentiometric surface of the intermediate aquifer system at this well generally was about $1 \mathrm{ft}$ lower than the water table in the surficial aquifer, indicating that the two aquifers are hydraulically connected.

\section{CFI-1 Creek}

The CFI-1 Creek basin is in northwestern Hardee County, $6.5 \mathrm{mi}$ west of Bowling Green (fig. 2), and has been reclaimed using the sand-clay settling method. The basin has a single dike along the western perimeter and is rhomboid in shape (approximately 3,000 ft wide by $2,700 \mathrm{ft}$ long). The average slope of the basin is $26 \mathrm{ft} / \mathrm{mi}$. Land cover in the basin consists of pasture in the headwaters, a densely wooded stand of willow trees in the central area of the basin, and a wetland area along the lower reach of CFI- 1 Creek. Land surface in the basin ranges from approximately $130 \mathrm{ft}$ above sea level along the northern boundary to approximately $115 \mathrm{ft}$ above sea level at the streamflow-gaging station (fig. 34). The gaged drainage area of CFI-1 Creek is 160 acres $\left(0.25 \mathrm{mi}^{2}\right)$.

The basin is divided into two subbasins by a slightly elevated haul road. Runoff in the upper subbasin collects in a large central depression and drains through a shallow swale to the lower subbasin and then to the streamflow-gaging station. The stream channel is poorly defined and absent in some places.

The dike along the western perimeter of the basin was left in place after reclamation to restrict runoff from the basin and to maintain a wetland area. Drainage from the wetland area is through a 100 -ft-wide swale that has been cut through the dike. The elevation of the bottom of the swale was approximately $2.5 \mathrm{ft}$ above the elevation of the bed of the stream channel prior to this study. A shallow ditch was excavated in the swale at the beginning of the study in an unsuccessful attempt to improve drainage from the basin. The water surface in the wetlands fluctuated as a result of evaporation, leakage, and rainfall during the study period, and CFI-1 Creek at the gaging station remained dry throughout most of the study period. 


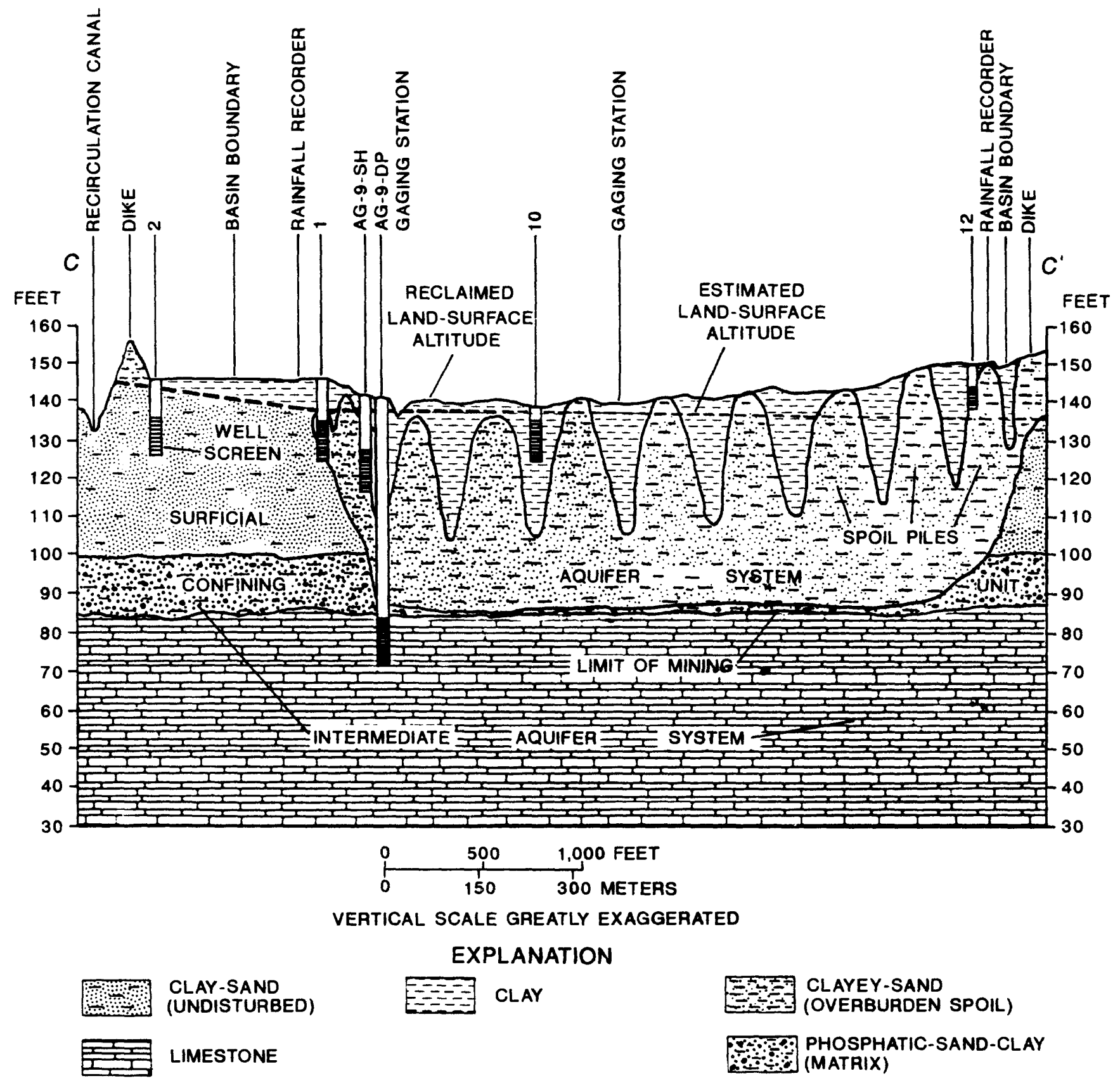

Figure 29. Hydrogeologic section C-C' at Agrico-9 Creek clay-settling basin. (Line of section is shown in fig. 28.) 


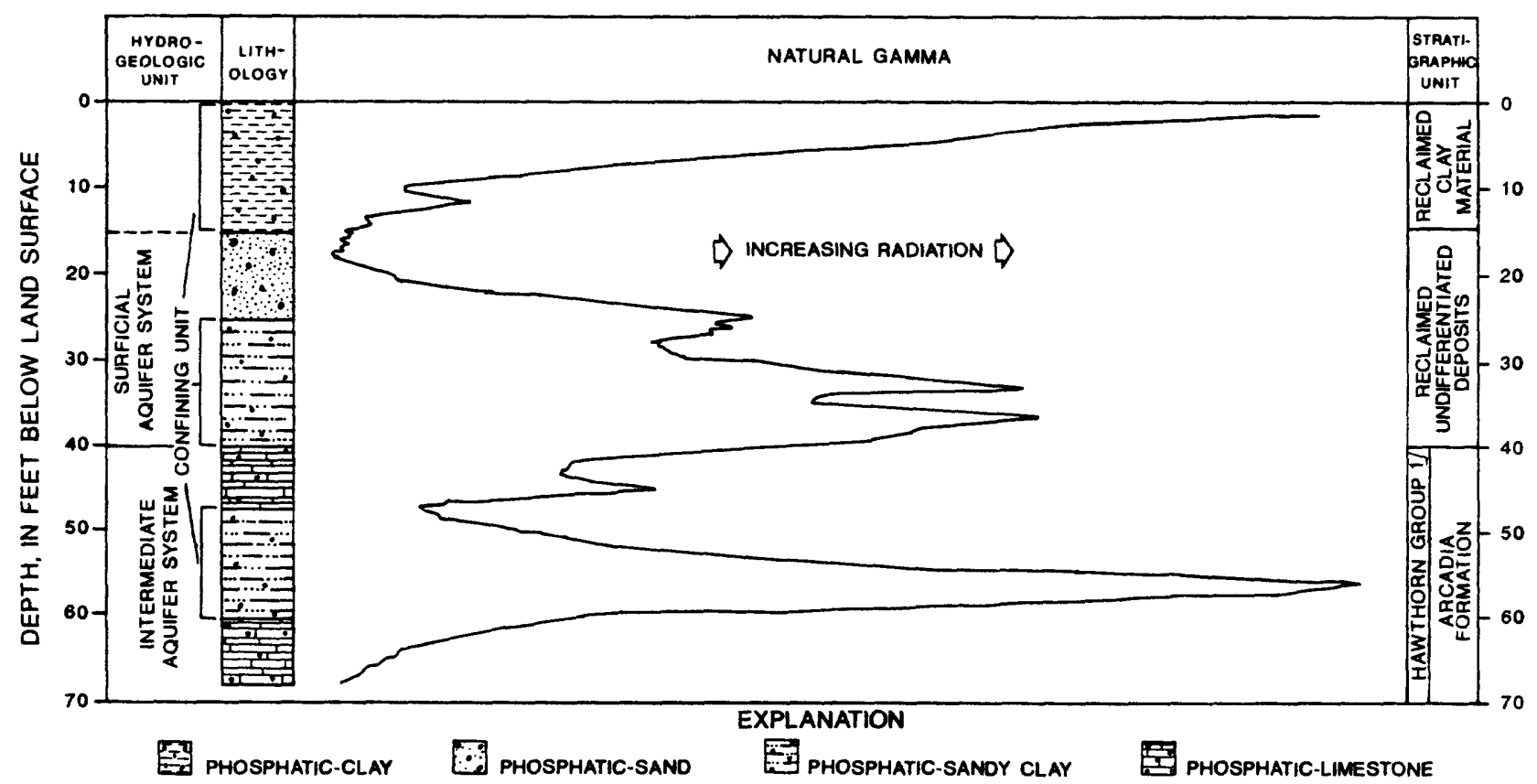

Figure 30. Hydrogeologic units, lithology, natural gamma-ray log, and stratigraphic units at well AG9-DP, completed in the intermediate aquifer system at the Agrico-9 Creek basin.

Streamflow for CFI-1 Creek was measured at a gaging station (CFI-1 Creek near Fort Green) located just upstream from the swale in the dike. An intense storm on September 6, 1988 , generated sufficient rainfall for runoff to fill the wetland area and to produce a peak discharge of $88 \mathrm{ft}^{3} / \mathrm{s}$ $\left(352\left(\mathrm{ft}^{3} / \mathrm{s}\right) / \mathrm{mi}^{2}\right)$ at the gaging station. This was the only flow recorded at the site during the study. Consequently, evaluation of the surface-water characteristics of the basin was limited.

The surficial deposits (overburden) were removed during strip mining operations at the basin and were deposited into adjacent mined cuts forming spoil piles. In preparation for the reclamation of the site, a large volume of the displaced overburden was redistributed to construct an elevated haul road through the center of the basin and a dike around the basin perimeter (fig. 35). As part of the reclamation process, waste sand and clay material was pumped in a water slurry to this basin. Sand and clay were deposited to a depth of approximately $10 \mathrm{ft}$ above the estimated natural grade of the basin during reclamation. This allowed the fill mixture to settle and consolidate to an altitude near that of the natural grade. The surficial sediments in the reclaimed area are composed of a heterogeneous mixture of sand and clay, unlike the stratified deposits characteristic of unmined areas. The hydraulic conductivity of the surficial aquifer system in reclaimed areas, computed from recovery tests at three wells, ranged from 1.2 to $11.0 \mathrm{ft} / \mathrm{d}$ (table 2). Lithologic and gammaray logs of well CFI1-DP near Fort Green indicate that the surficial aquifer system is $48 \mathrm{ft}$ thick and is composed of sands and clays that overlie the intermediate aquifer system (fig. 36).

Continuous water-level data for the surficial aquifer system in this basin were collected at a 25 -ft-deep well (CFI1-SH well near Fort Green). Water levels in this well ranged from $117.37 \mathrm{ft}$ above sea level $(7.61 \mathrm{ft}$ below land surface) in October 1988 to $114.01 \mathrm{ft}$ above sea level (10.97 ft below land surface) in June 1990 (fig. 37). Water-level fluctuations in this well (fig. 37) indicate that the aquifer responds rapidly to variations in recharge. The configuration of the water table of the surficial aquifer system during the seasonal low (June 1989) and high (August 1989) water-level periods indicates that the ground-water flow gradient generally is from the north to the southwest and that seepage occurs through the northern dike from the adjacent elevated sand-clay mixing pond (fig. 38). Water-level fluctuations in the 13 observation wells in the basin were measured periodically. The fluctuations were relatively uniform among all wells and reflected seasonal patterns in recharge (fig. 39).

Continuous water-level data for the intermediate aquifer system collected at the 60-ft-deep well, CFI1-DP, indicated the potentiometric surface for this aquifer ranged from $117.37 \mathrm{ft}$ above sea level in October 1988 to $113.81 \mathrm{ft}$ above sea level in June 1990 (fig. 37). The altitude of the potentiometric surface of the intermediate aquifer system generally was within $0.2 \mathrm{ft}$ of the altitude of the water table in the overlying surficial aquifer system, indicating that the two systems are hydraulically connected. 


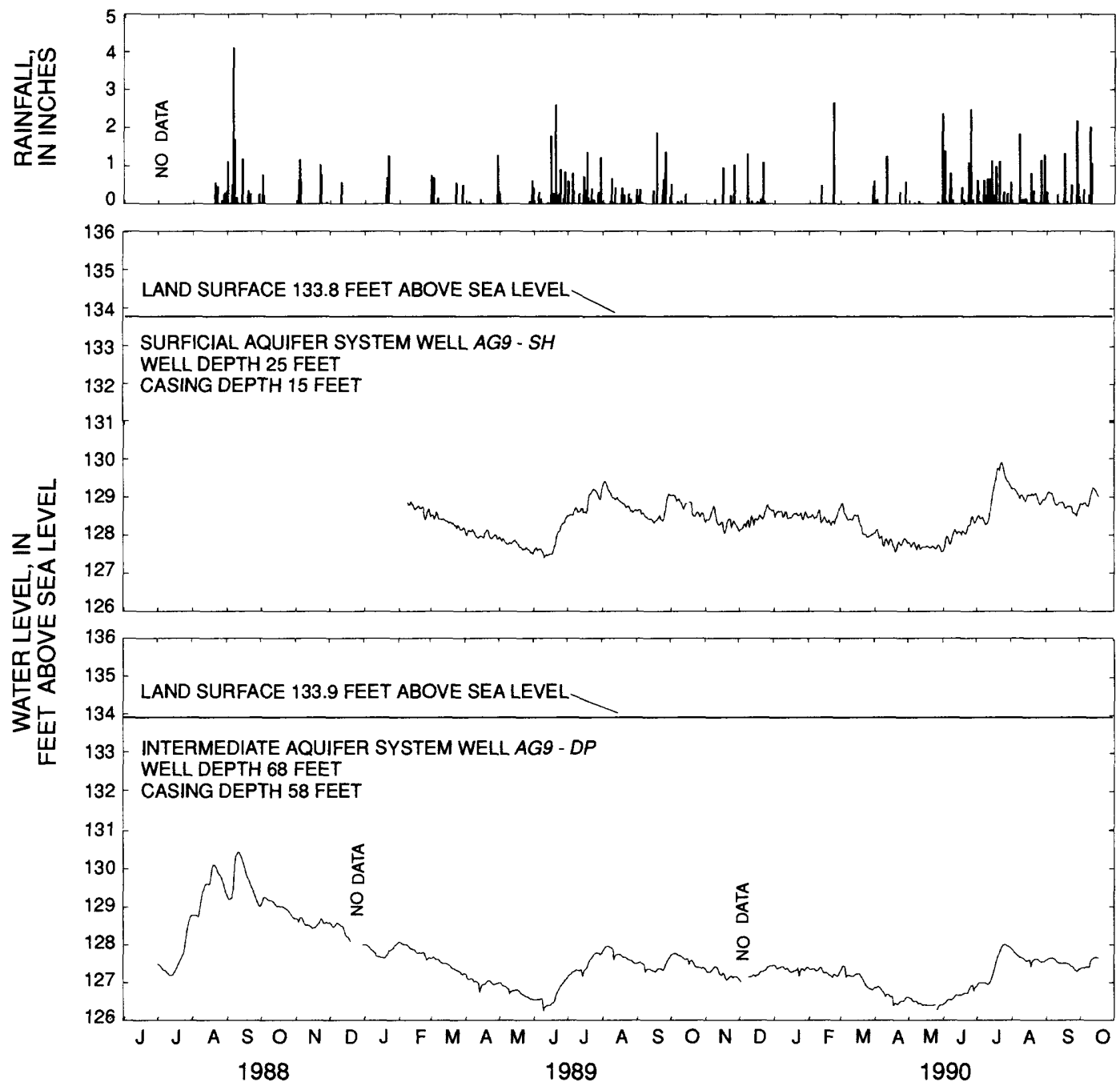

Figure 31. Daily rainfall and ground-water levels in monitor wells at Agrico-9 Creek basin, June 1988 to October 1990.

\section{Agrico-4 Creek}

The Agrico-4 Creek drainage basin is in southwestern Polk County, 6 mi east of Fort Lonesome and $1 \mathrm{mi}$ southwest of the intersection of State Roads 674 and 37 (fig. 2), and has been reclaimed using the overburden-capped sand-tailings method. The basin is flat, and land use is predominantly pasture, with a small wetland area along the downstream reach of the creek. Land surface in the basin ranges from approximately $140 \mathrm{ft}$ above sea level along the western boundary to approximately $130 \mathrm{ft}$ above sea level at the mouth of the creek (fig. 40). The basin is rectangular in shape (approximately 2,800 ft wide by 3,000 ft long) and has an average slope of $18 \mathrm{ft} / \mathrm{mi}$. The gaged drainage area of Agrico-4 Creek basin is approximately 150 acres $\left(0.23 \mathrm{mi}^{2}\right)$.

The reclaimed Agrico-4 Creek basin has a gently contoured slope and lacks a well-defined streamflow channel. Low flow was measured using a sharp-crested weir at the gaging station (Agrico-4 Creek near Fort Lonesome) located just upstream from the mouth of the creek. Discharge from the basin ranged from 0 to $24 \mathrm{ft}^{3} / \mathrm{s}\left(104\left(\mathrm{ft}^{3} / \mathrm{s}\right) / \mathrm{mi}^{2}\right)$. During periods of extreme high flow in Payne Creek, backwater caused flooding throughout much of the Agrico-4 Creek basin.

During mining of this basin, the overburden was deposited into adjacent mined-out cuts, forming large piles of displaced overburden spoil. After the basin was mined, sandtailings separated from the phosphate matrix at the beneficiation plant were pumped to the basin as a slurry to backfill between the rows of spoil piles. The tops of the overburden piles were then graded over the sand-tailings to form a cap and contoured. This method of reclamation resulted in landsurface altitudes similar to those of the natural surface prior to mining (fig. 41). Lithologic and gamma-ray logs of well AG4-DP indicate that the surficial aquifer system in the reclaimed basin consists of a 15 - $\mathrm{ft}$-thick overburden cap, a $10-\mathrm{ft}$-thick bed of sand-tailings, and a 15 -ft-thick lens of additional overburden material that overlies the intermediate aquifer system (fig. 42). 
Continuous water-level data for the surficial aquifer system in this basin were collected at a 25 -ft-deep well (AG4-SH well near Fort Lonesome). Water levels in this well ranged from $135.09 \mathrm{ft}$ above sea level $(0.19 \mathrm{ft}$ below land surface) in July 1990 to $132.05 \mathrm{ft}$ above sea level $(2.85 \mathrm{ft}$ below land surface) in June 1989 (fig. 43). The hydrograph for this well shows that the water level in the surficial aquifer responds rapidly to variations in recharge. The flat topography in the basin and the lack of an incised drainage network limit ground-water contributions (base flow) to Agrico-4 Creek. Configurations of the water table of the surficial aquifer system, based on water-level measurements in well AG4-SH and in 10 observation wells measured periodically, are shown for a seasonal low (June 1989) and a high (October 1989) water-level period in figure 44. Water-level hydrographs for the 10 observation wells reflect seasonal variations in water levels of about $4 \mathrm{ft}$ (fig. 45). Hydraulic conductivities at two wells completed in the surficial aquifer system, computed from recovery tests, were 8.4 and $57.8 \mathrm{ft} / \mathrm{d}$ (table 2). The high hydraulic conductivity value of $57.8 \mathrm{ft} / \mathrm{d}$ indicates that the well screen may have been set in the highly permeable, washed sand-tailings.

Continuous water-level data for the intermediate aquifer system in the basin were collected at a 65-ft-deep well (AG4-DP) and indicate that the potentiometric surface at this well ranged from $135.18 \mathrm{ft}$ above sea level in July 1990 to
$132.09 \mathrm{ft}$ above sea level in June 1990 (fig. 43). The altitude of the potentiometric surface at this well generally was within $0.2 \mathrm{ft}$ of the altitude of the water table in the surficial aquifer system, indicating that the two systems are hydraulically connected.

\section{Agrico-1 Creek}

Agrico-1 Creek basin is in southwestem Polk County, $1.5 \mathrm{mi}$ west of Baird and $2 \mathrm{mi}$ north of the Polk-Hardee County line (fig. 2), and has been reclaimed using the contoured-overburden method. The basin is triangular in shape (approximately $4,000 \mathrm{ft}$ wide and 3,400 ft long). Much of the basin is in pasture, but the basin includes a 20 -acre lake bordered by wetlands (fig. 46). Topography of the basin is characterized as relatively flat; land surface ranges in altitude from approximately $135 \mathrm{ft}$ above sea level along the northern boundary to approximately $125 \mathrm{ft}$ above sea level downstream from the lake. The length of the channel is approximately $3,200 \mathrm{ft}$ (including the lake), and the average channel slope is $16 \mathrm{ft} / \mathrm{mi}$. The gaged drainage area of the Agrico-1 Creek basin is approximately 140 acres $\left(0.22 \mathrm{mi}^{2}\right)$.

The drainage network is poorly developed or absent, except for a swale that runs the length of the basin. Runoff generally flows overland to the lake near the center of the basin.
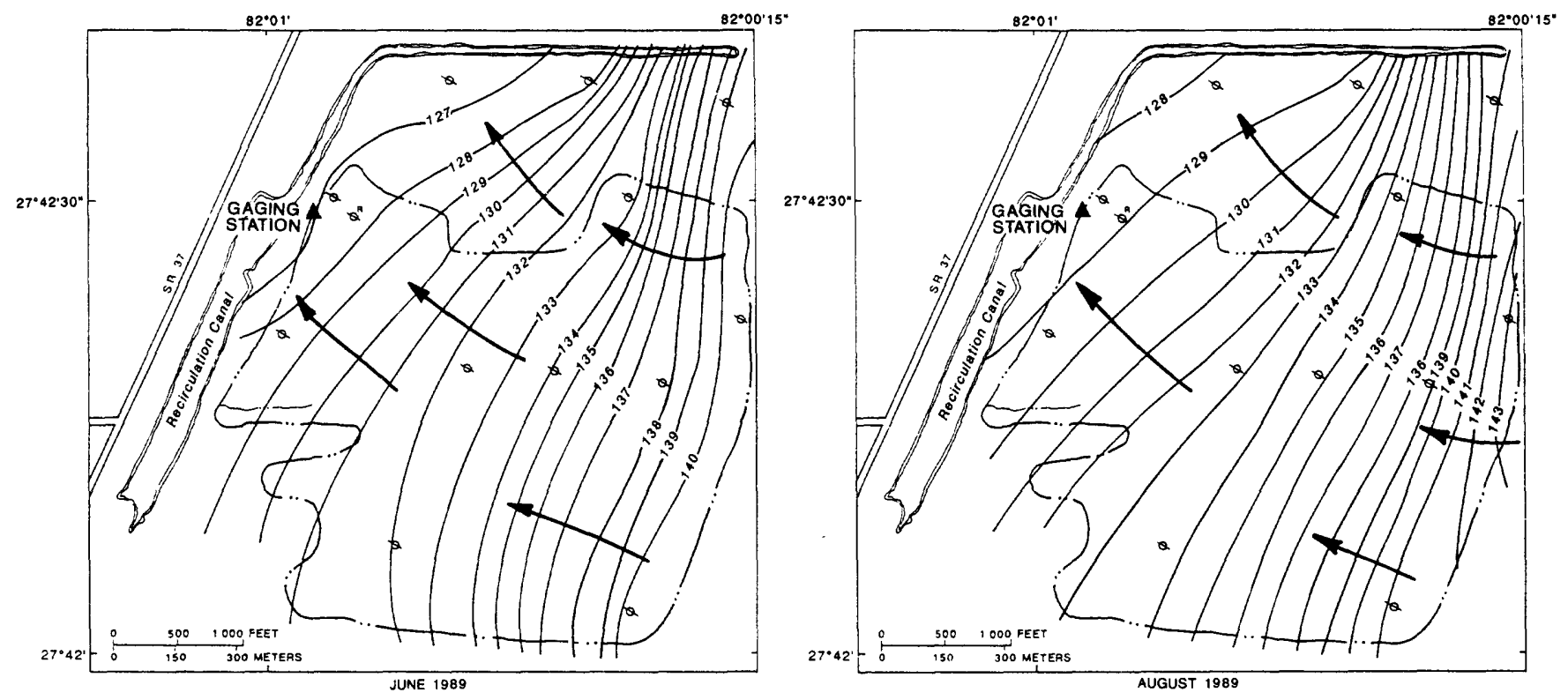

EXPLANATION

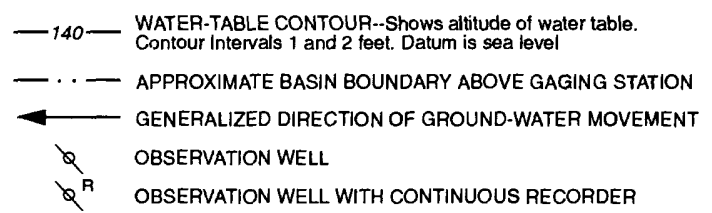

Figure 32. Configuration of the water table in the surficial aquifer system at Agrico-9 Creek basin, June and August 1989 . 


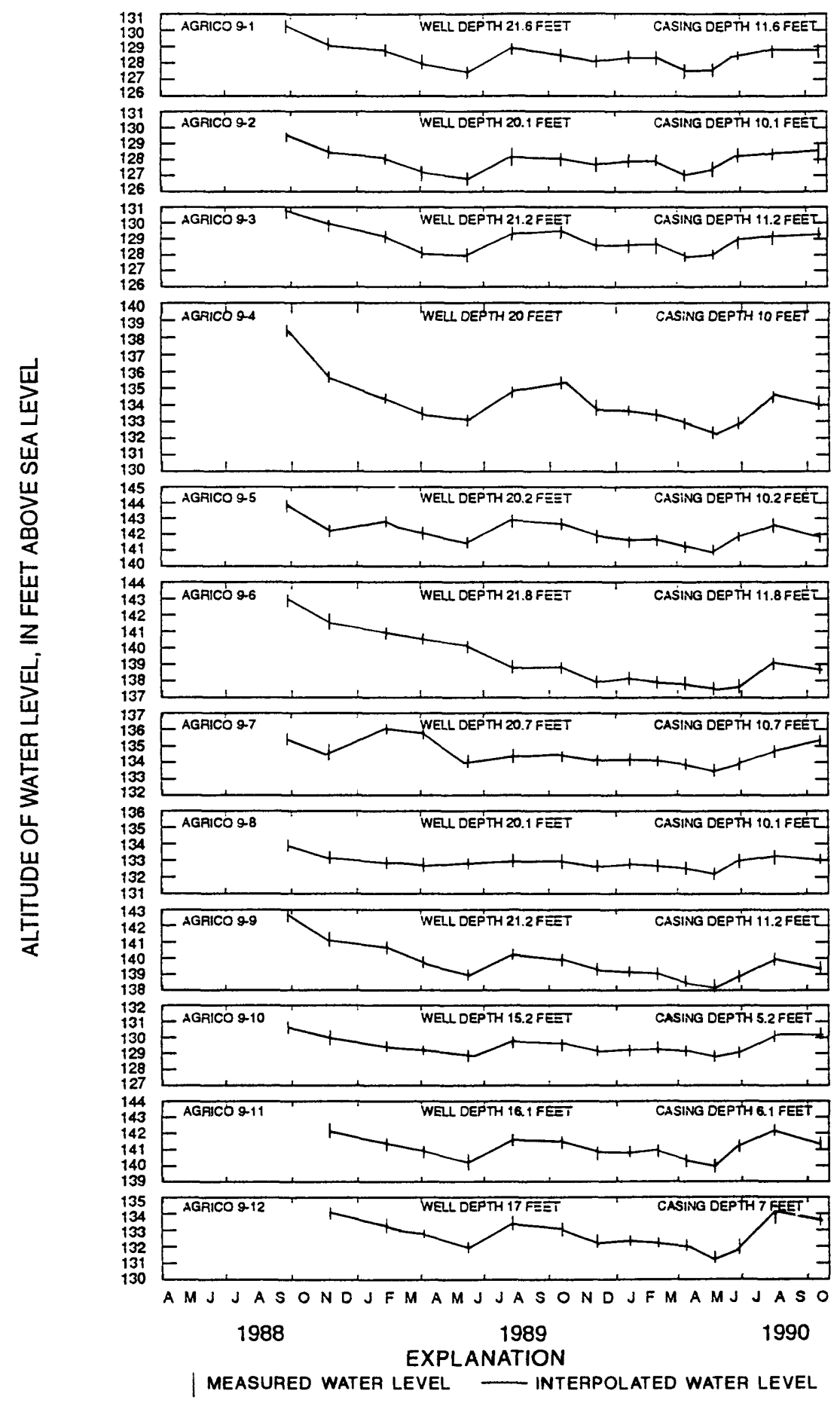

Figure 33. Water levels based on periodic measurements in wells completed in the surficial aquifer system, Agrico-9 Creek basin, September 1988 to October 1990 . 


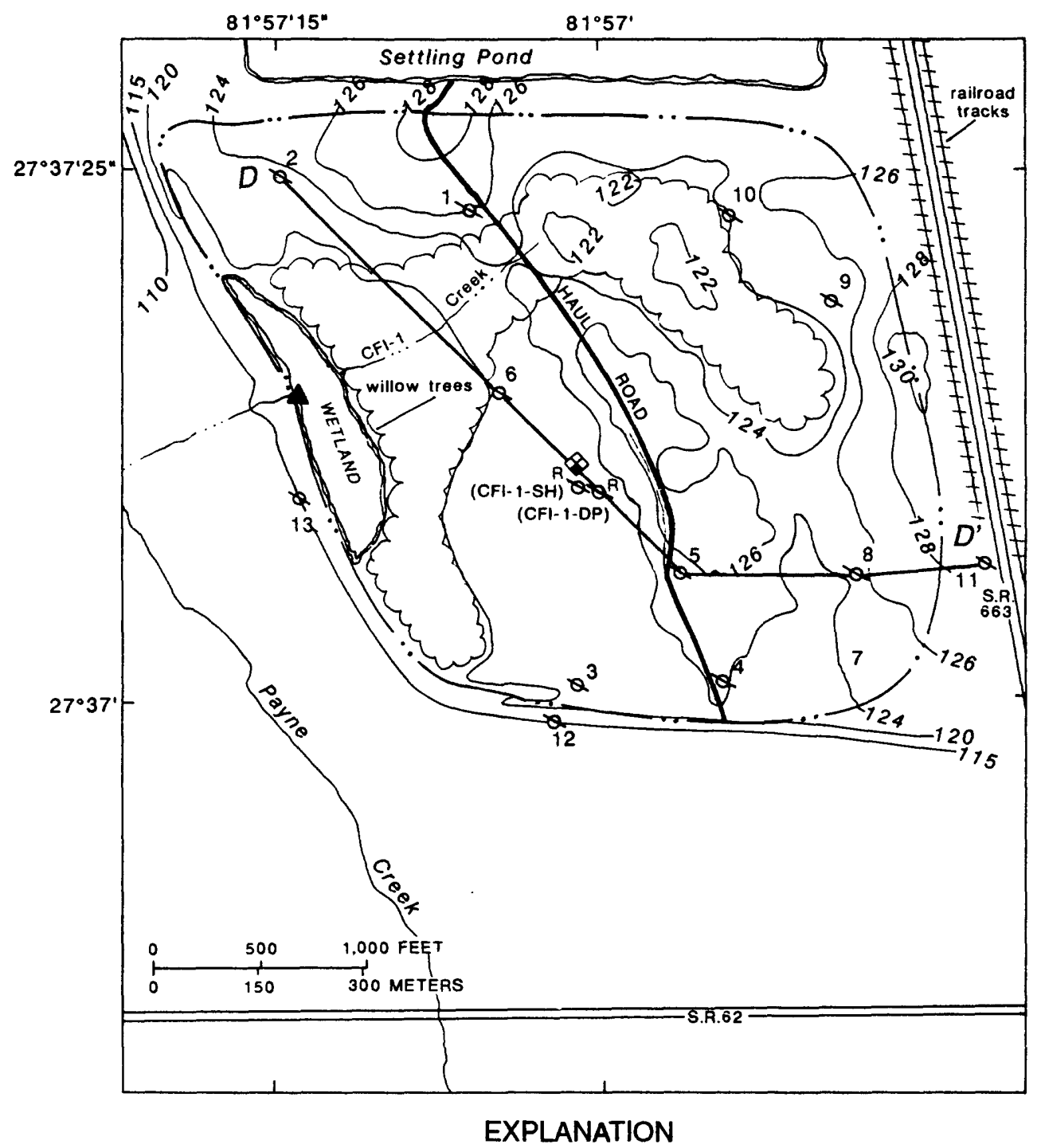

TOPOGRAPHIC CONTOUR--Showing altitude of land surface.
Contour interval 2,4 , and 5 feet. Datum is sea level

—.. APPROXIMATE BASIN BOUNDARY ABOVE GAGING STATION

$D$ - $D^{\prime} \quad$ LINE OF GENERALIZED HYDROGEOLOGIC SECTION

$Q^{3}$ SURFICIAL AQUIFER SYSTEM WELL AND NUMBER

$Q^{R}$ CFI-1-SH SURFICIAL AQUIFER SYSTEM WELL WITH CONTINUOUS RECORDER

$Q^{R}$ CFI-1-DP INTERMEDIATE AQUIFER SYSTEM WELL WITH CONTINUOUS RECORDER

STREAMFLOW GAGING STATION
$\otimes$ RAINFALL RECORDING GAGE

Figure 34. Location of CFI-1 Creek basin, topography, data-collection network, and line of hydrogeologic section D-D'. 


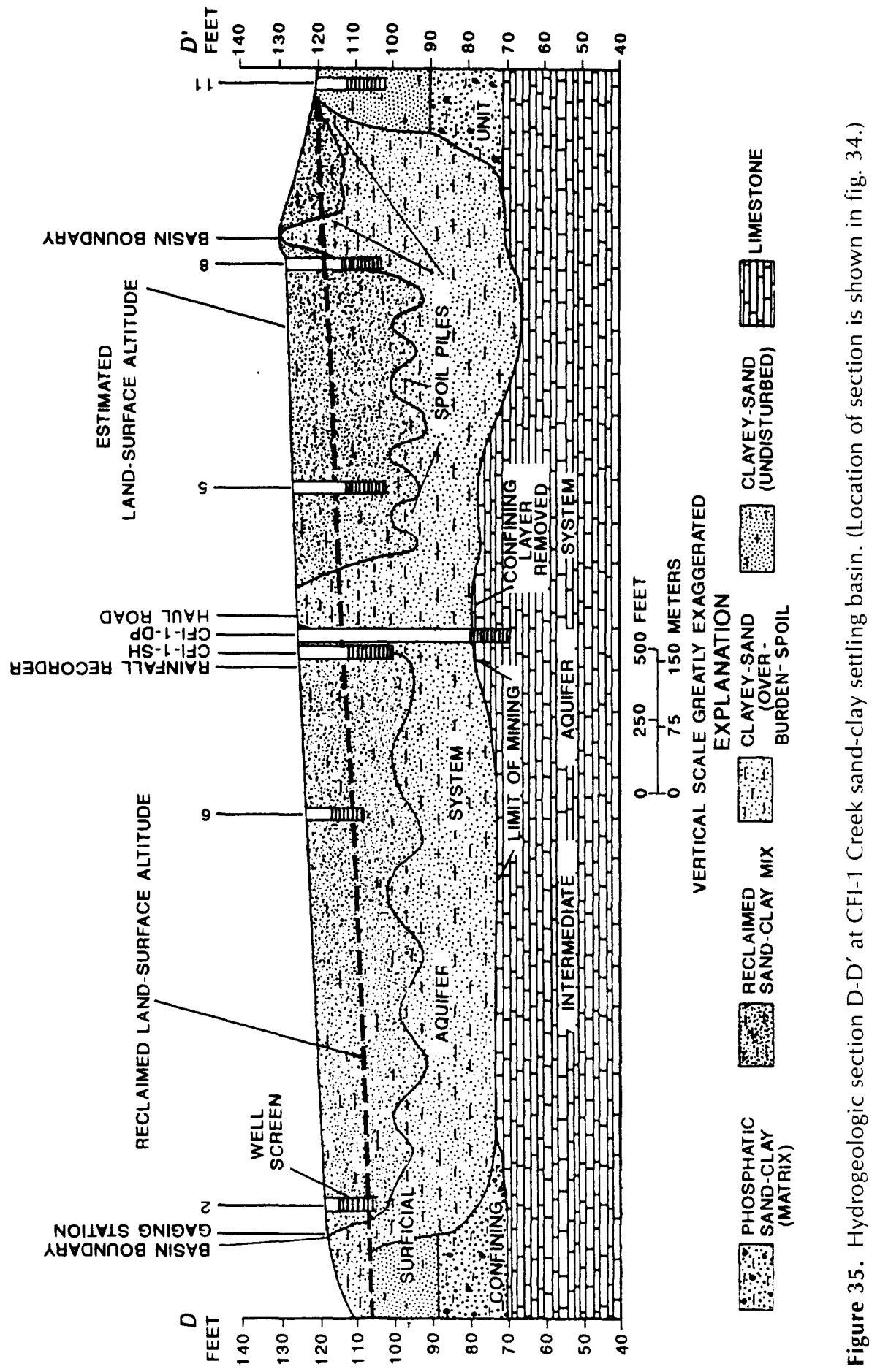




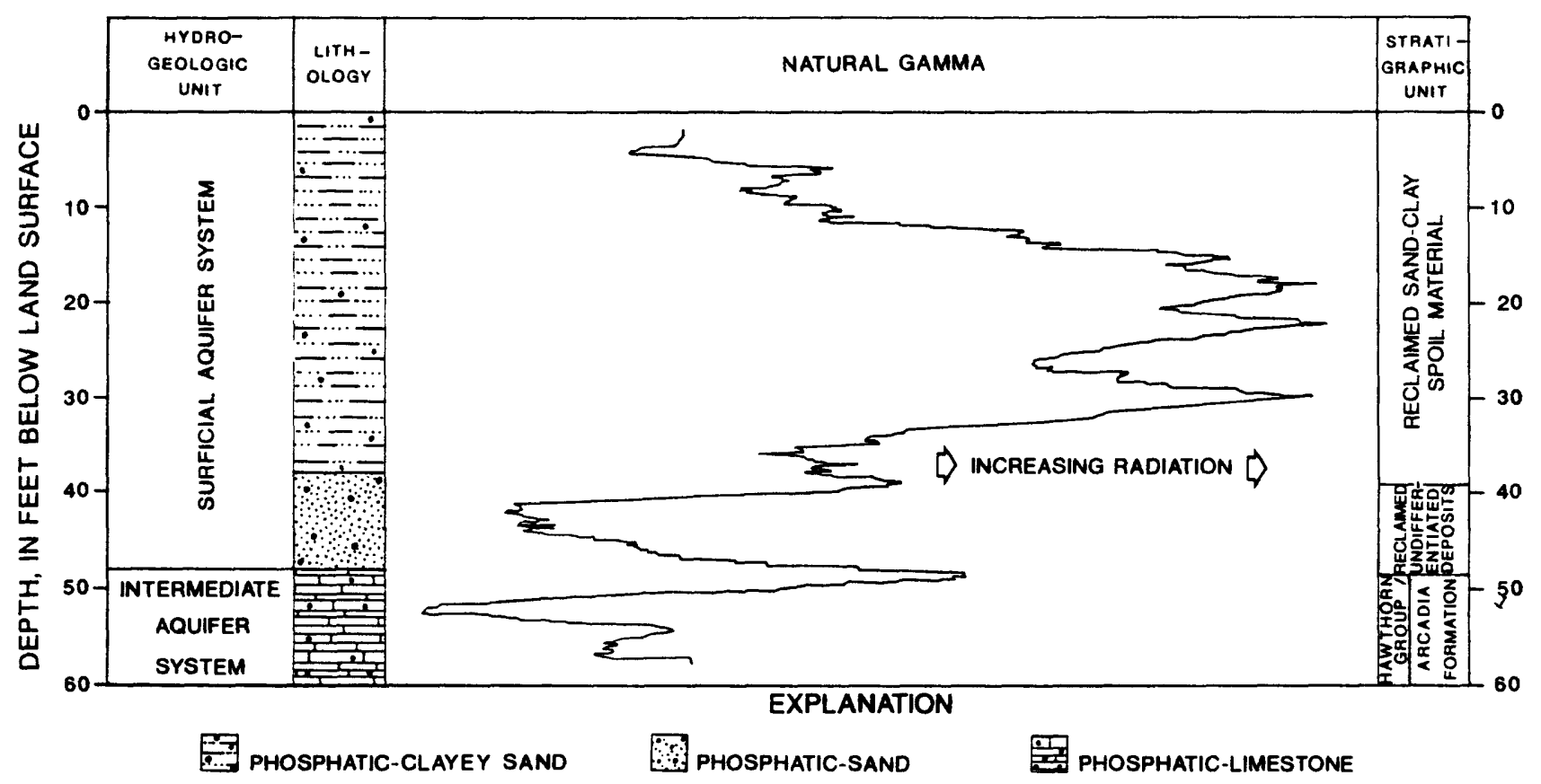

Figure 36. Hydrogeologic units, lithology, natural gamma-ray log, and stratigraphic units at well CFI1-DP, completed in the intermediate aquifer system at the CFI-1 Creek basin.

Outflow from the lake flows through an approximately 250 -ftlong broad swale to the point where a streamflow-gaging station (Agrico-1 Creek near Fort Green) was established. Discharge during the study period ranged from 0 to $24 \mathrm{ft}^{3} / \mathrm{s}$ $\left(109\left(\mathrm{ft}^{3} / \mathrm{s}\right) / \mathrm{mi}^{2}\right)$.

The basin was reclaimed using only the existing onsite overburden that was displaced during mining. During reclamation, earth-moving equipment pushed the tops of the spoil piles into the adjacent mined-out cuts and contoured the overburden to form a gently sloping surface of low relief (fig. 47). Land surface of the reclaimed basin is lower than the premined natural grade because of the removal of the phosphate matrix during mining. Lithologic and gamma-ray logs of well AG1-DP indicate that the reclaimed, undifferentiated deposits that constitute the surficial aquifer system are approximately $35 \mathrm{ft}$ thick (fig. 48).

Continuous water-level data for the surficial aquifer system in this basin were collected at a 25 -ft-deep well (AG1-SH). Water levels in this well ranged from $129.42 \mathrm{ft}$ above sea level $(0.10 \mathrm{ft}$ above land surface) in July 1990 to $124.58 \mathrm{ft}$ above sea level $(4.77 \mathrm{ft}$ below land surface) in August 1988 (fig. 49). The configuration of the water table of the surficial aquifer system, based on water-level measurements in well AG1-SH and in 13 observation wells measured periodically during this study, are shown for seasonal low (June 1989) and high (August 1989) water-level periods in figure 50. The range in water-level fluctuations is approximately $1 \mathrm{ft}$, and the general direction of ground-water flow in the surficial aquifer system throughout the basin is toward the lake. Seasonal fluctuations in water levels were generally uniform throughout the basin and reflected recharge from rainfall (fig. 51). However, an approximate $2-\mathrm{ft}$ rise in the water level at well AG1-SH, and similar rises in observation wells 1 through 4, was observed in December 1988 when there was relatively little rainfall. This water-level rise probably was the result of ongoing reclamation at an adjacent basin.

Water-level fluctuations in well AG1-SH indicate the surficial aquifer system has a slightly delayed response to recharge from rainfall infiltration when compared to unmined sites. Ground-water discharge to Agrico-1 Creek and the lake is limited because of the low topographic relief of the basin and the lack of a developed incised drainage network.

An aquifer test was performed on the surficial aquifer system to evaluate the aquifer characteristics of the disturbed overburden. Monitor well PC-SP-01, installed about $800 \mathrm{ft}$ beyond the southwest basin boundary by Agrico Chemical Company, was used for the aquifer test. The 6-in.-diameter well was cased to $25 \mathrm{ft}$ and screened from 25 to $35 \mathrm{ft}$. The aquifer test results indicated that the surficial aquifer system was capable of yielding water at a rate of only $1.5 \mathrm{gal} / \mathrm{min}$. The results of the test were considered inconclusive because of the low discharge rate. In contrast, Hutchinson (1978) reported discharge rates of 17.5 and $48 \mathrm{gal} / \mathrm{min}$ for aquifer tests at two surficial aquifer system wells completed in unmined (natural) overburden within the phosphate-mining area. Hydraulic conductivities at two Agrico-1 Creek wells completed in the surficial aquifer system, as computed from slug-recovery tests, were 0.2 and $0.5 \mathrm{ft} / \mathrm{d}$ (table 2 ). 
Continuous water-level data for the intermediate aquifer system were collected at a 55-ft-deep well (AG1-DP). The potentiometric surface at this well ranged from $124.33 \mathrm{ft}$ above sea level in June 1988 to $128.37 \mathrm{ft}$ above sea level in July 1990 (fig. 49). The altitude of the potentiometric surface at this well generally was within about $1 \mathrm{ft}$ of the altitude of the water table in the surficial aquifer system, which indicates that the two systems are hydraulically connected.

\section{EFFECTS OF LAND RECLAMATION ON HYDROGEOLOGY}

The occurrence and movement of water in the surficial and intermediate aquifer systems have been affected by the type of backfill used in the reclamation process. The surficial aquifer system in each reclaimed basin responds differently to recharge from rainfall. The permeability of the backfill material-sand, clay, or overburden-can affect the amount of ground water discharged to streams as base flow. The rate

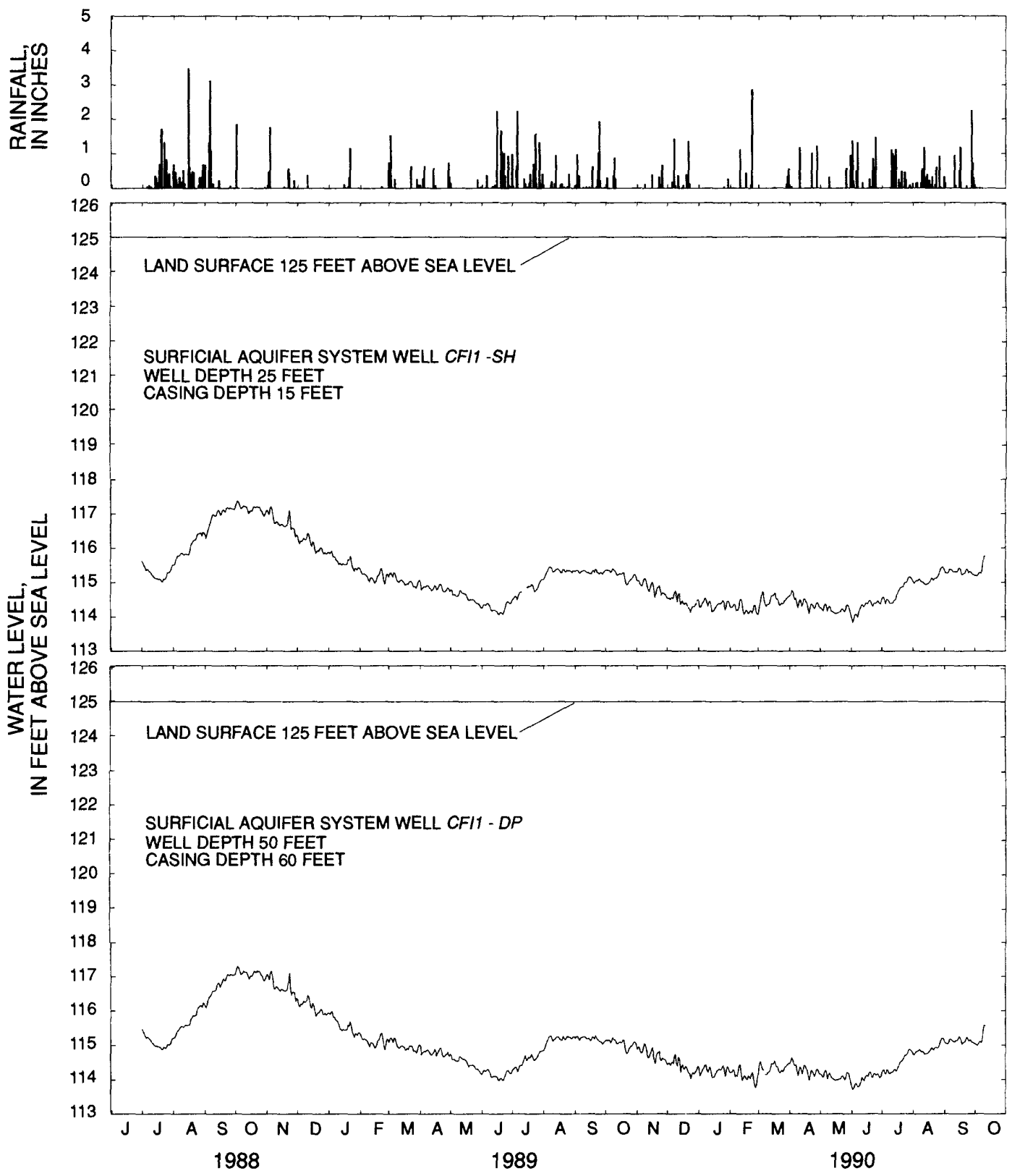

Figure 37. Daily rainfall and ground-water levels in monitor wells at the CFI-1 Creek basin, June 1988 to October 1990. 

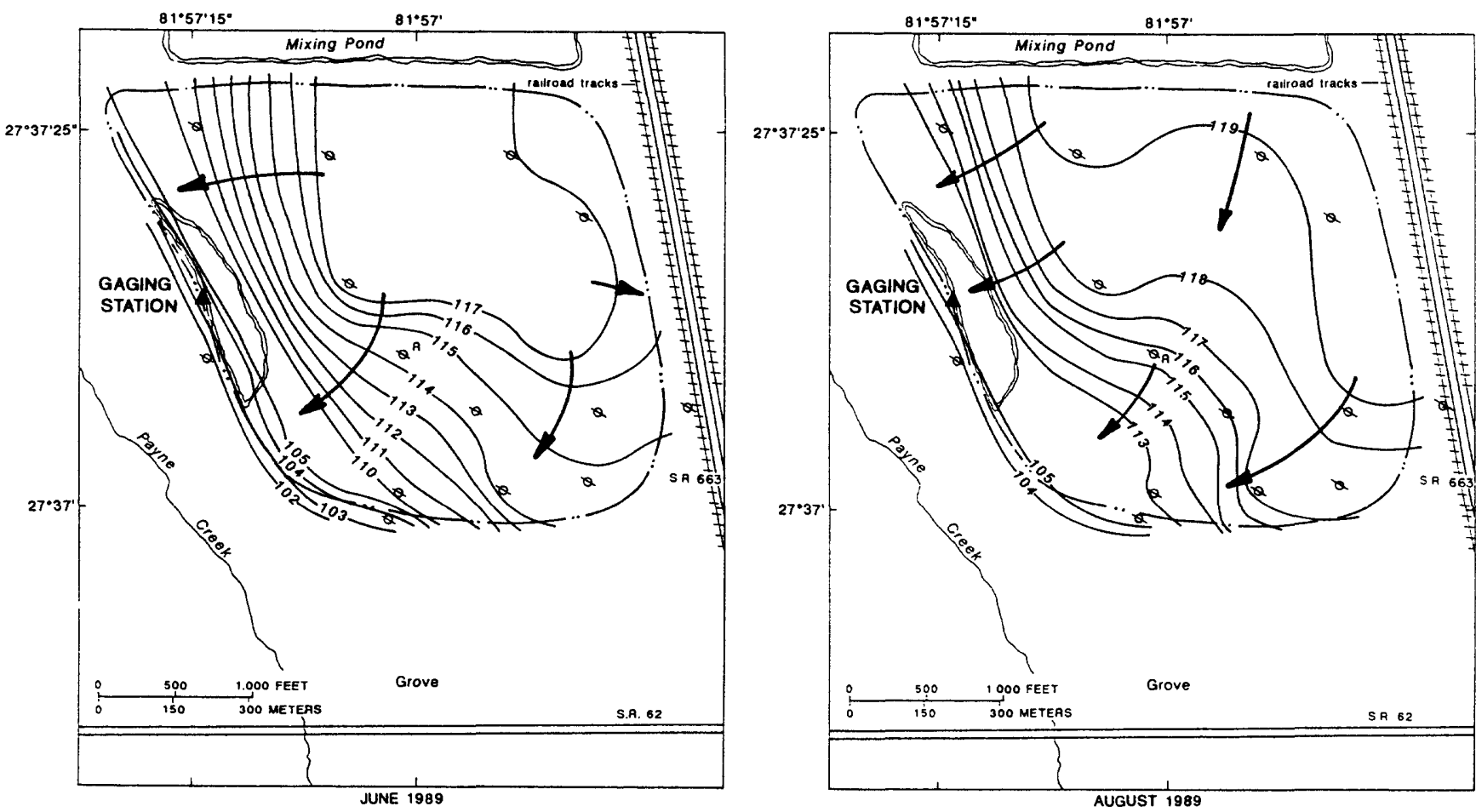

\section{EXPLANATION}

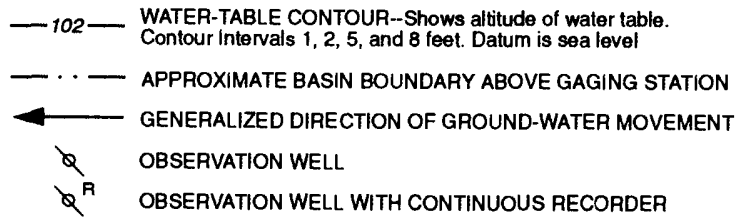

Figure 38. Configuration of the water table in the surficial aquifer system at the CFI-1 Creek basin, June and August 1989 .

of recharge to the intermediate aquifer system from the overlying surficial aquifer system varies with the type of reclamation method used. The matrix that was removed during mining formed part of the upper confining unit of the intermediate aquifer system. Absence of the upper confining unit permits a direct hydraulic connection between the two aquifer systems and causes them to react as one system.

\section{Surficial Aquifer System}

Similar patterns of water-level fluctuations in the surficial aquifer system (water table) were observed in hydrographs for wells in all eight study basins; however, the response of water levels to rainfall and seasonal trends in water levels varied among the basins (fig. 52). Recharge to the surficial aquifer system is by infiltration of rainfall, by percolation from surface runoff that has collected in depressions or impoundments above the water table, and by lateral flow from adjacent areas. Discharge of ground water generally is to lakes or streams that intersect the water table and to deeper aquifers. Ground-water levels at unmined basin wells IMC-SH, Grace-SH, and CFI3-SH rose sharply in response to rainfall and generally were within about $5 \mathrm{ft}$ of land surface.

Major differences in the response of the water table to rainfall recharge exist between the natural and reclaimed basins. Ground-water levels in all of the reclaimed basins show seasonal variations. Water levels in the clay-settling basin well, MBL-SH, however, responded more slowly to rainfall recharge and generally had smaller seasonal fluctuations (fig. 25). The clay layer that overlies the more permeable overburden material within the clay-settling basins apparently restricts the downward infiltration of water, and fluctuations in water levels in these areas are attributed largely to horizontal ground-water flow from adjacent areas. The clay-settling basins, Mobil Creek and Agrico-9 Creek, and the sand-clay settling basin, CFI-1 Creek, had the largest average depths to water below land surface, approximately 12,5 , and $10 \mathrm{ft}$, respectively. These relatively low water levels are attributed to the low permeability of the clay backfill material and possibly to the flow 


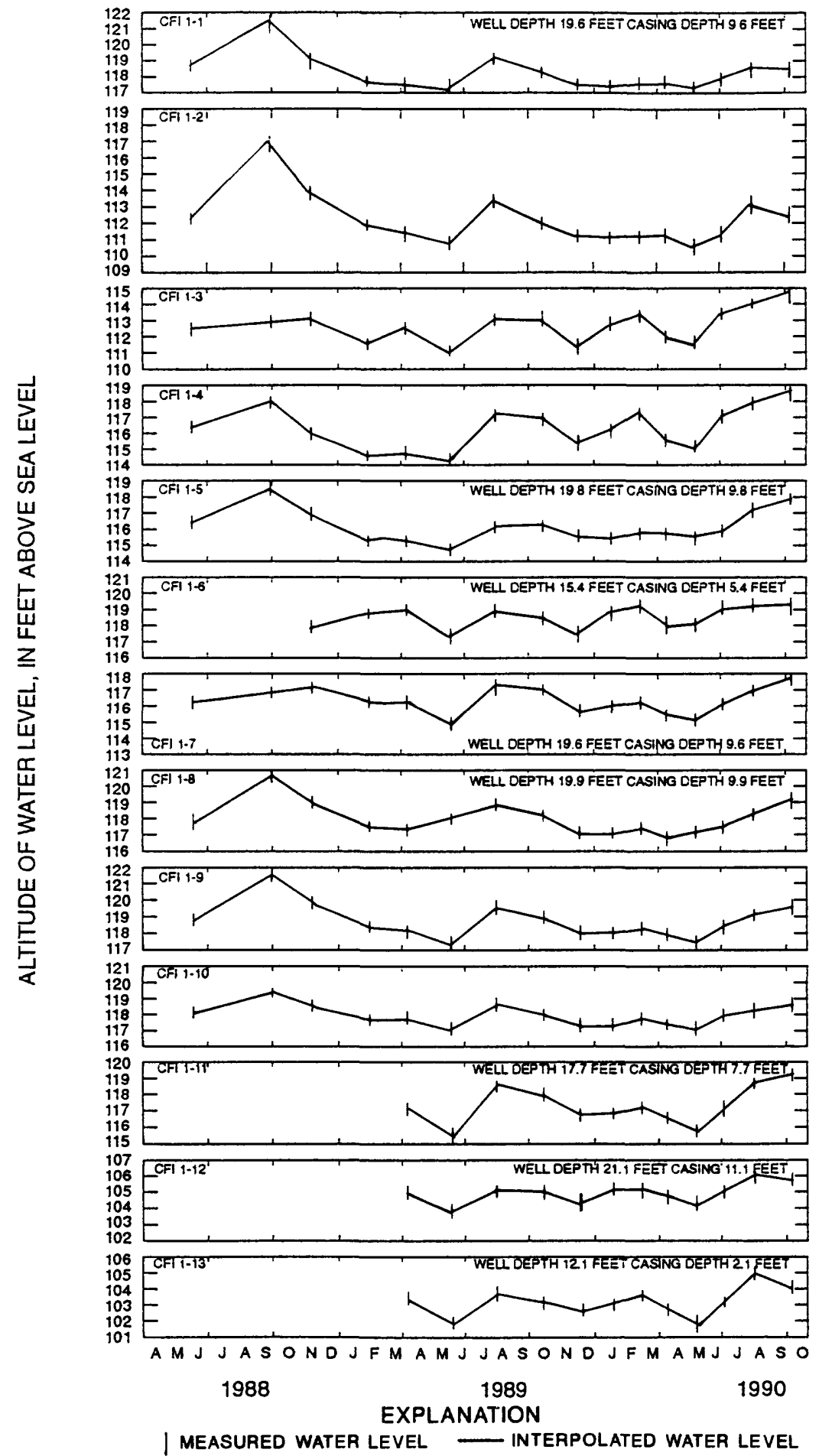

Figure 39. Water levels based on periodic measurements in wells completed in the surficial aquifer system at the CFI-1 Creek basin, June 1988 to October 1990. 


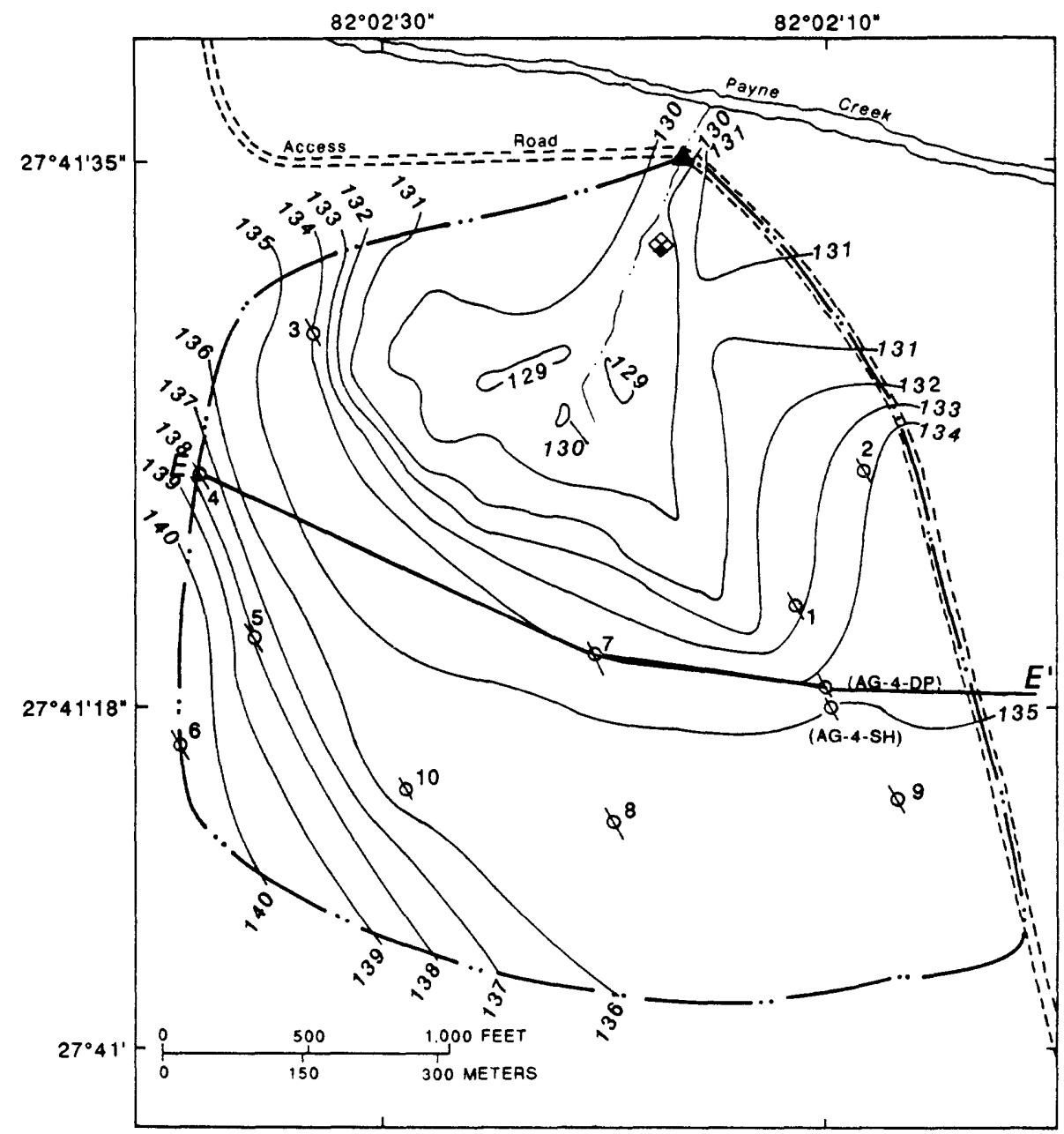

EXPLANATION

- 136- TOPOGRAPHIC CONTOUR--Showing altitude of land surface. Contour interval 1 foot. Datum is sea level

- - APPROXIMATE BASIN BOUNDARY ABOVE GAGING STATION

$E-E^{\prime} \quad$ LINE OF GENERALIZED HYDROGEOLOGIC SECTION

$Q^{10}$ SURFICIAL AQUIFER SYSTEM WELL AND NUMBER

$Q^{R}$ AG-4-SH SURFICIAL AQUIFER SYSTEM WELL WITH CONTINUOUS RECORDER

$Q^{R}$ AG-4-DP INTERMEDIATE AQUIFER SYSTEM WELL WITH CONTINUOUS RECORDER

A STREAMFLOW GAGING STATION

RAINFALL RECORDING GAGE

Figure 40. Location of Agrico-4 Creek basin, topography, data-collection network, and line of hydrogeologic section $\mathrm{E}-\mathrm{E}^{\prime}$. 


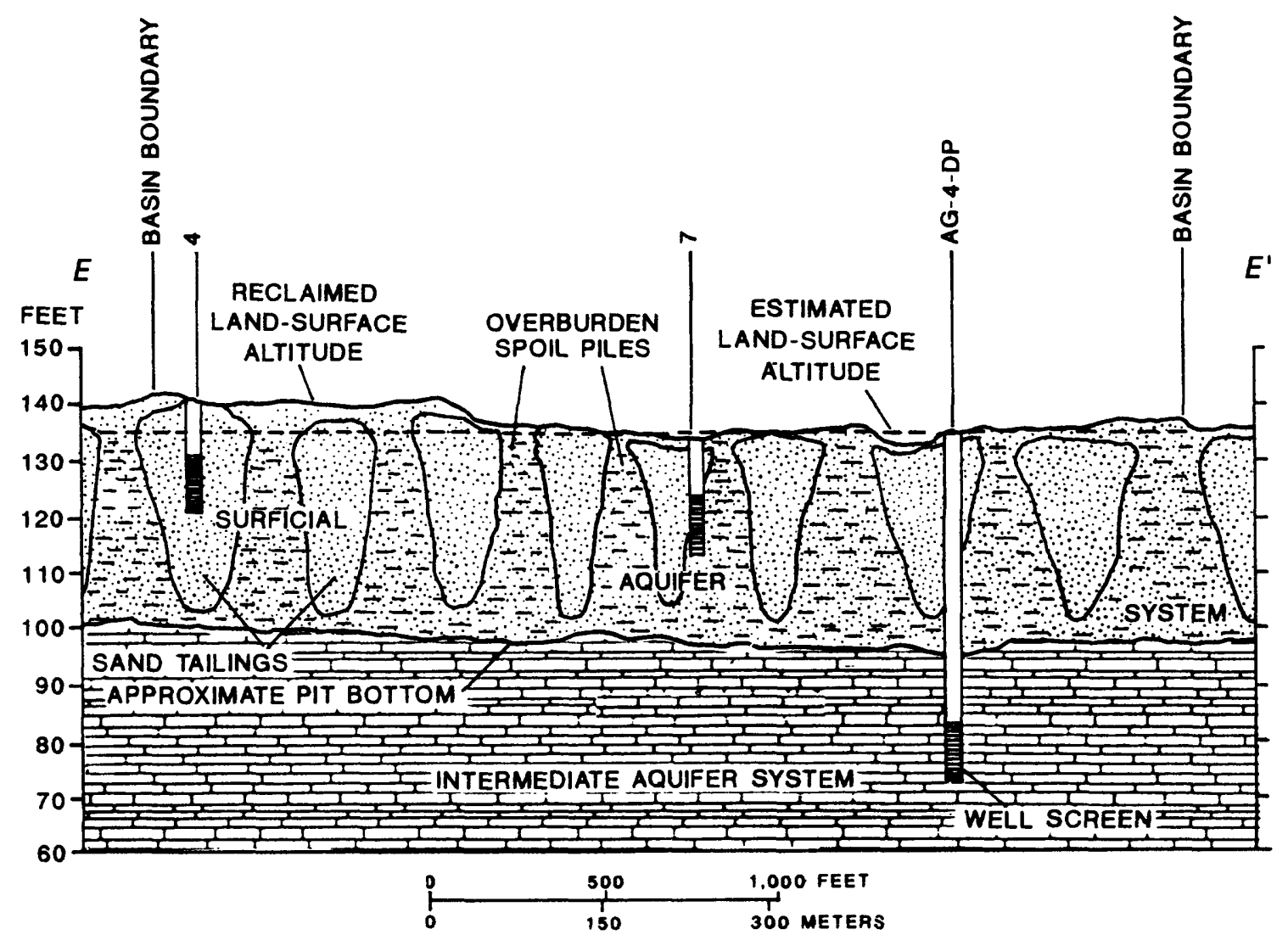

VERTICAL SCALE GREATLY EXAGgERATED

EXPLANATION
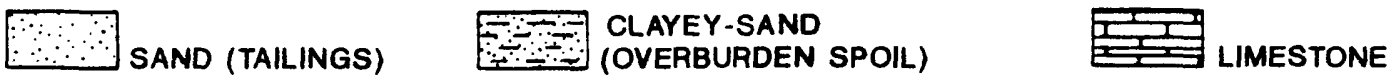

Figure 41. Hydrogeologic section $E-E^{\prime}$ at Agrico-4 Creek overburden-capped sand-tailings basin. (Location of section is shown in fig. 40.)

of water from the surficial aquifer system to the hydraulically connected underlying intermediate aquifer system. Water levels in wells in clay and sand-clay settling basins (figs. 25, 31 , and 37) did not fluctuate in response to variations in streamflow, which indicates that the surface-water and ground-water systems have little hydraulic connection. The water table in the clay and sand-clay settling basins was generally below the level of the incised stream channel and streams received no base flow. Computed hydraulic conductivities of the surficial aquifer system in the clay and sand-clay settling basins, where the open-screen intervals of the wells selected for slug-recovery testing were set in either clay or overburden, ranged from less than 0.01 to $11.0 \mathrm{ft} / \mathrm{d}$. The low hydraulic conductivities were for wells screened in clay, and the higher values were for wells screened in overburden. Hydraulic conductivities at the CFI-1 Creek (sandclay settling) basin were higher than those at the Mobil Creek or Agrico-9 Creek (clay-settling) basins because of the greater permeability of the sand-clay backfill material.
Of the five reclaimed basins studied, the Agrico-4 Creek basin (overburden-capped sand-tailings) had ground-water level fluctuations (well AG4-SH) that most closely resembled the water-level fluctuations in the surficial aquifer system at the unmined basins. The water-level response to rainfall infiltration, however, was slower in this basin than in the unmined basins (fig. 43). The approximate 3-ft depth to water below land surface at the Agrico-4 Creek basin was similar to that at the unmined basins. Hydraulic conductivity values generally were lower in most of the reclaimed basins when compared to the unmined basins, except at Agrico-4 Creek well 2 where the hydraulic conductivity $(57.8 \mathrm{ft} / \mathrm{d})$ was three times higher than the highest value determined at the unmined basins. This high hydraulic conductivity is attributed to the high permeability of the sand-tailings in which the well screen was set. Water levels in the AG1-SH well at the Agrico-1 Creek reclaimed basin (contoured-overburden) fluctuated less dramatically in response to seasonal variations in rainfall than did the water levels in the AG4-SH well at Agrico-4 Creek basin. 


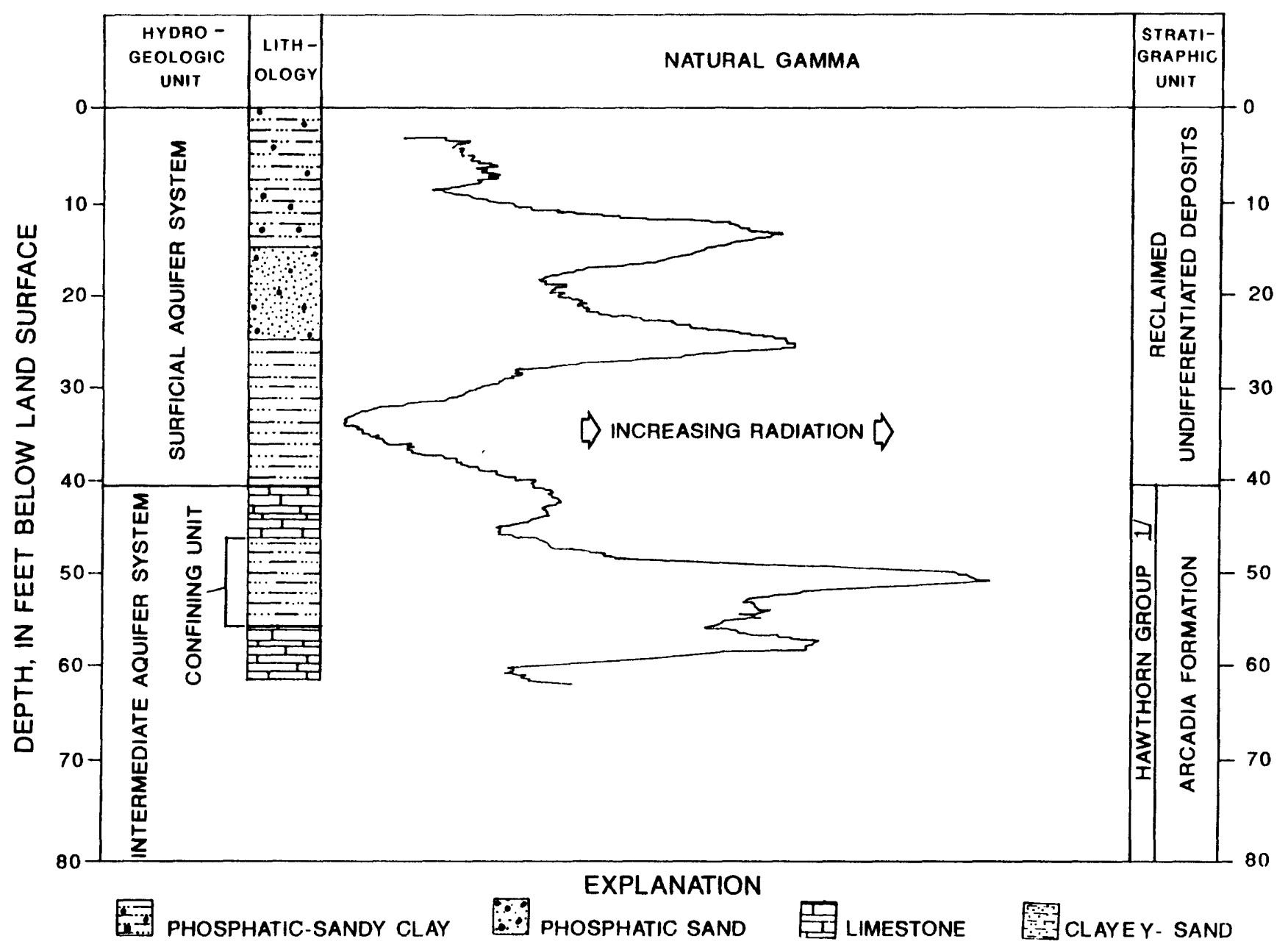

Figure 42. Hydrogeologic units, lithology, natural gamma-ray log, and stratigraphic units at well AG4-DP, completed in the intermediate aquifer system at the Agrico-4 Creek basin.

\section{Intermediate Aquifer System}

The intermediate aquifer system contains discontinuous layers of limestone and dolomite separated by clay, sand, and silt. The aquifer system underlies the unconsolidated deposits of the surficial aquifer system throughout the study area.

Hydrographs for the intermediate aquifer system wells at the three unmined basins, ROMP-48 (IMC Creek), Grace-DP, and CFI3-DP (fig. 53), show water-level fluctuations that are similar to the seasonal patterns of water-level fluctuations in the overlying surficial aquifer system, but do not show the sharp water-level rises related to recharge from individual storms (figs. 9, 14, and 19). Differences between the altitude of the water table in the surficial aquifer system and the altitude of the potentiometric surface of the intermediate aquifer system in the unmined basins generally ranged from 4 to $10 \mathrm{ft}$, which indicates the systems are separated by the upper confining unit of the intermediate aquifer system and are not in good hydraulic connection.
Differences in the consistency of the clay fill and the distribution of the overburden spoil at the two clay-settling basins, Mobil Creek and Agrico-9 Creek, have resulted in different ground-water systems overlying the intermediate aquifer system at these sites. At Mobil Creek, the clay backfill has consolidated and extends upward from the limestone of the intermediate aquifer system to land surface, functioning much like a confining unit. The hydrograph for well MBL-DP (fig. 25) shows a 10-ft range in seasonal water-level fluctuations and a 15- to 20 - $\mathrm{ft}$ difference between the water table in the surficial aquifer system and the potentiometric surface of the intermediate aquifer system. The phosphate matrix, which formed the upper confining unit of the intermediate aquifer system, and the overburden were removed during mining and were replaced by a thick layer of clay during reclamation. This clay restricts ground-water recharge and limits the hydraulic connection between the surficial and intermediate aquifer systems. 

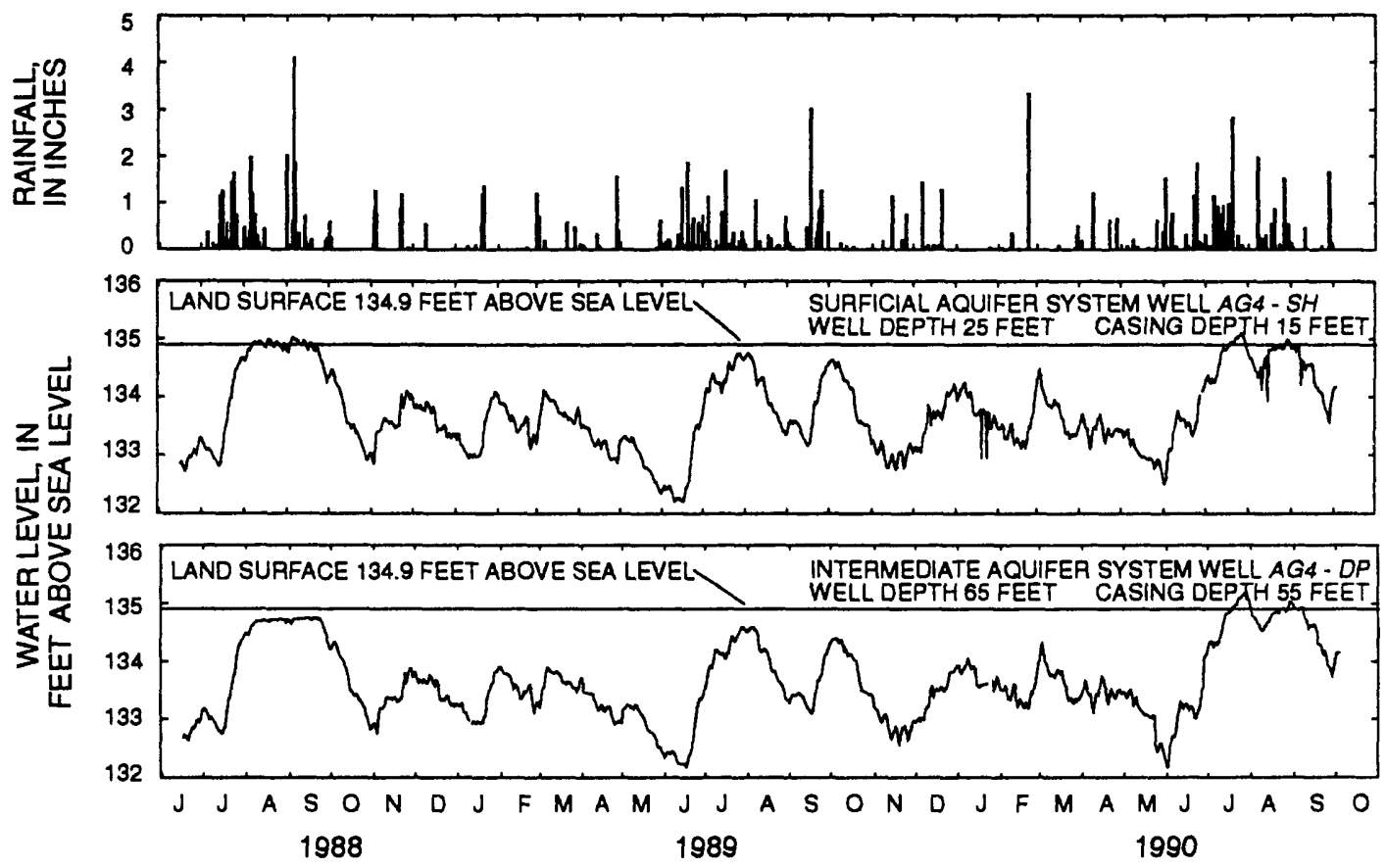

Figure 43. Daily rainfall and ground-water levels in monitor wells at Agrico-4 Creek basin, June 1988 to October 1990.
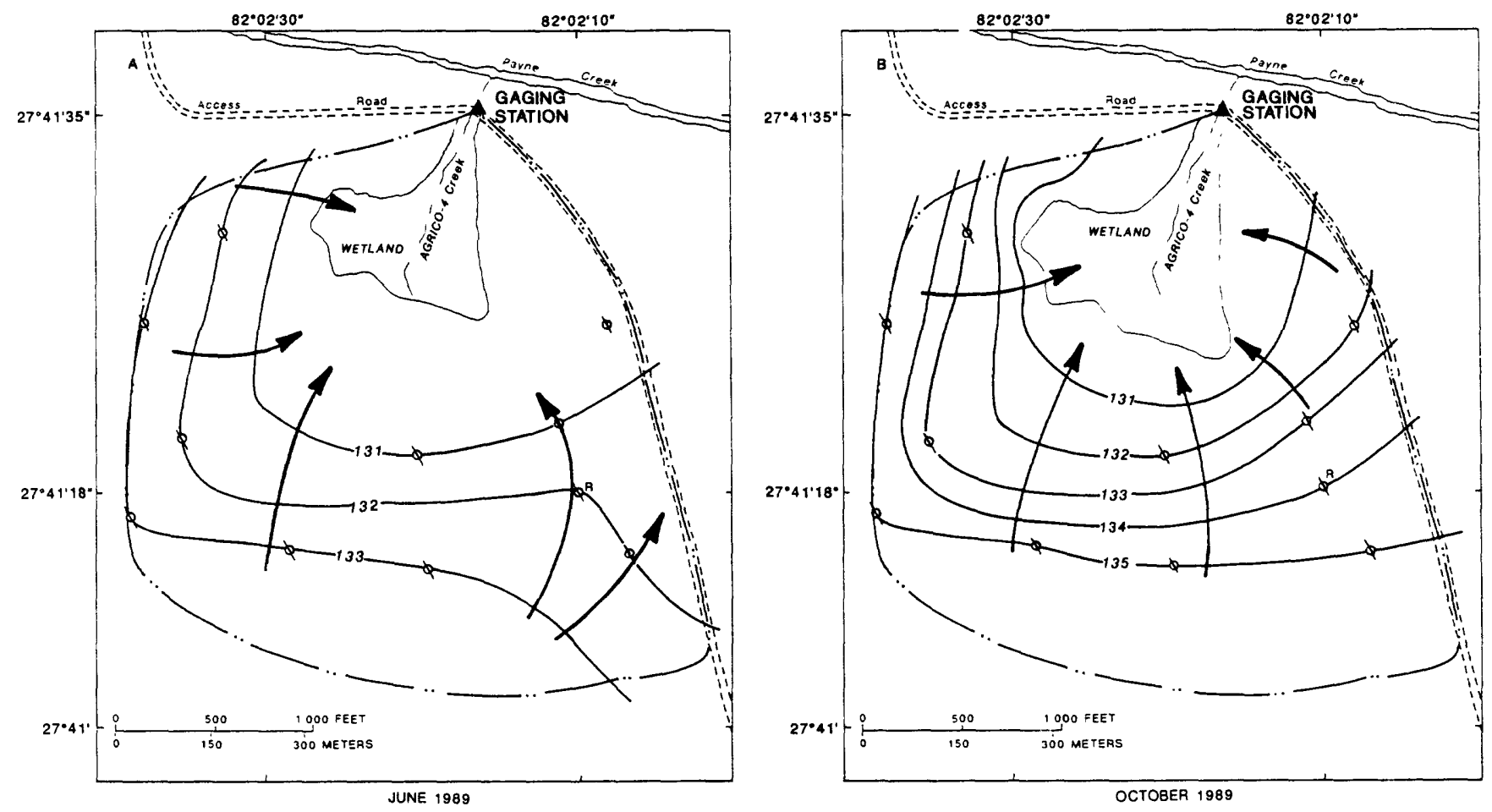

EXPLANATION

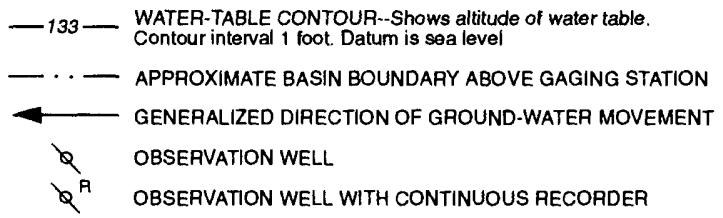

Figure 44. Configuration of the water table in the surficial aquifer system at Agrico-4 Creek basin, June and October 1989. 


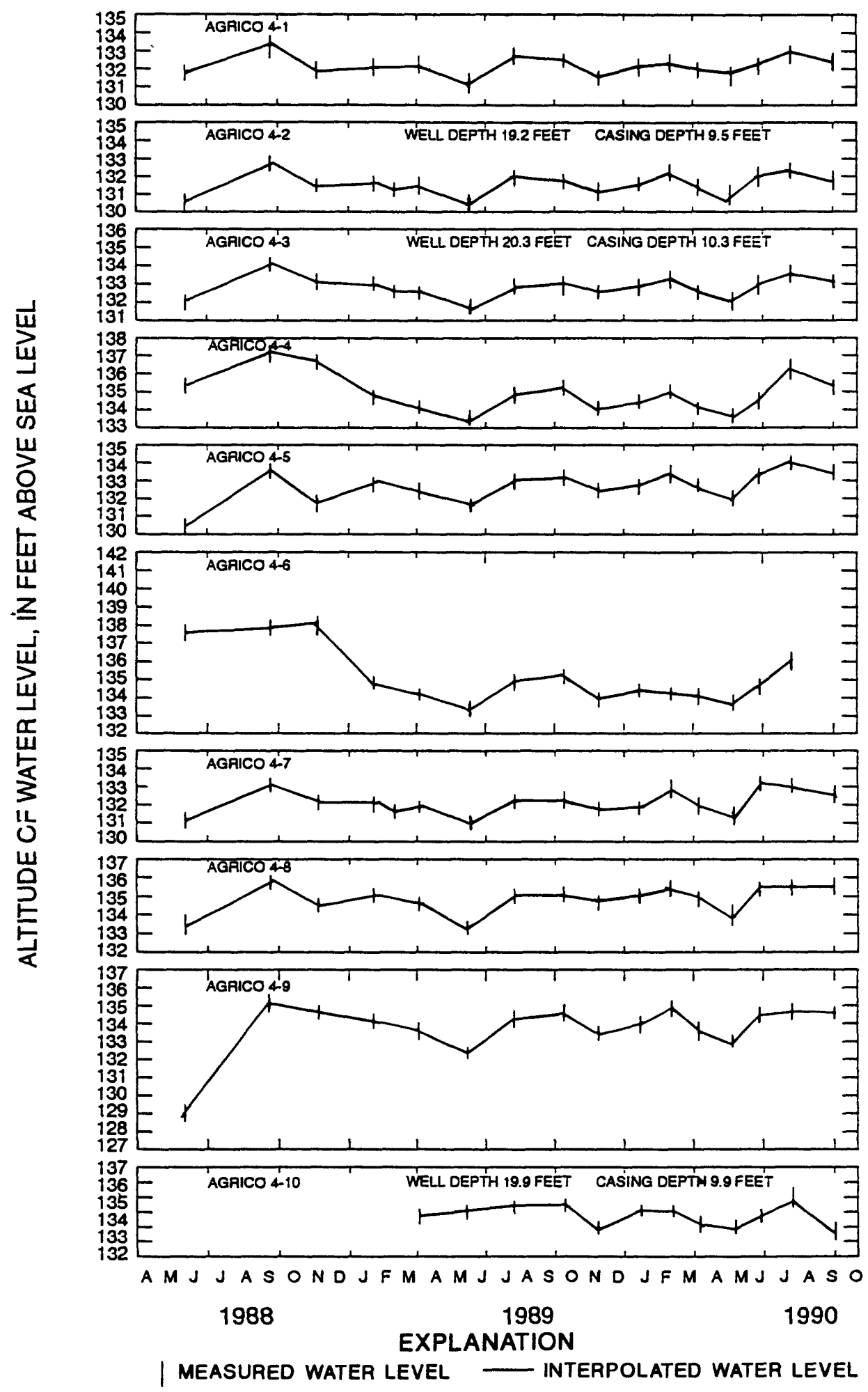

Figure 45. Water levels based on periodic measurements in wells completed in the surficial aquifer system at the Agrico-4 Creek basin, June 1988 to October 1990. 


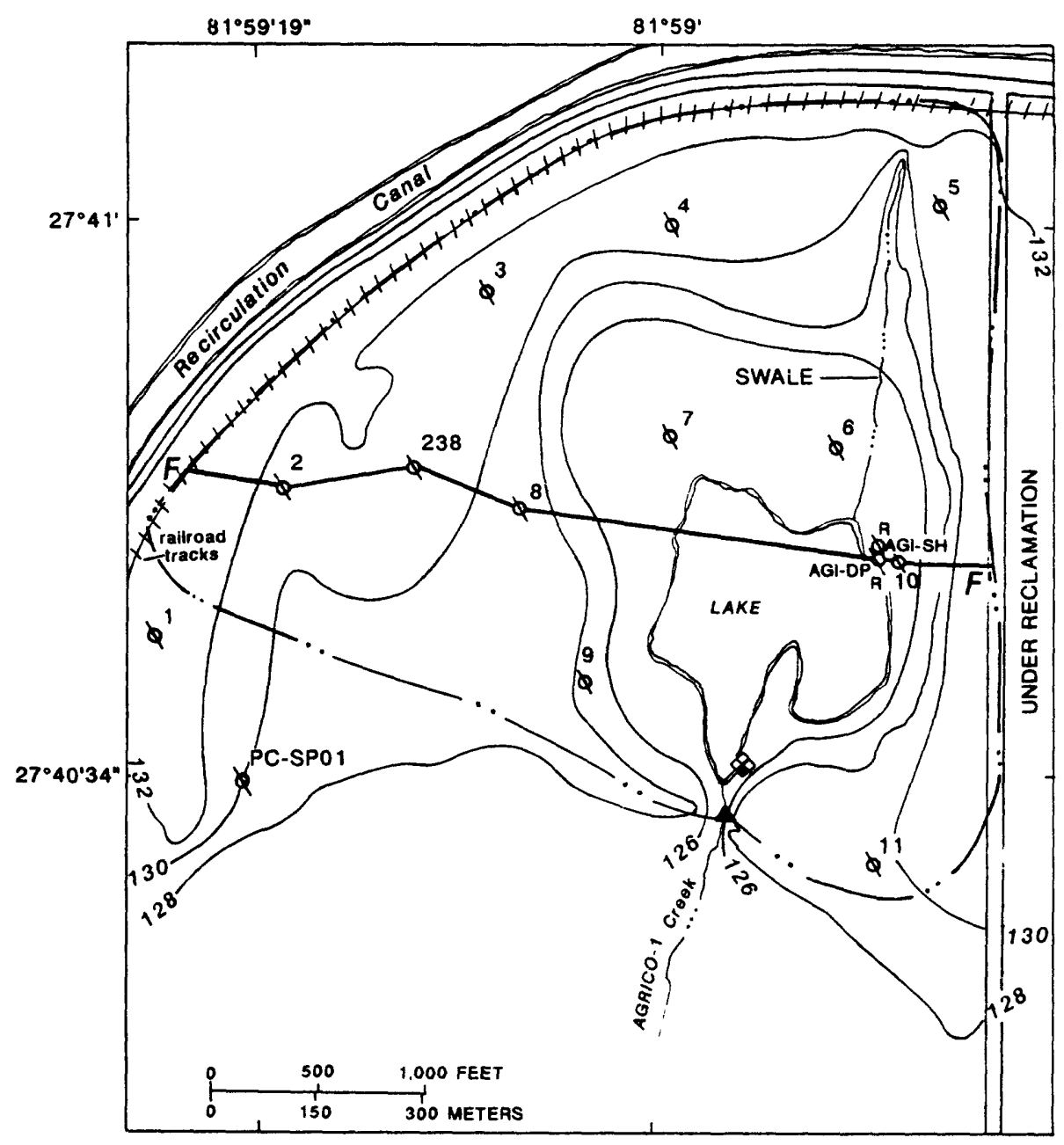

EXPLANATION

TOPOGRAPHIC CONTOUR-Showing altitude of land surface.
Contour interval 2 feet. Datum is sea level

_... APPROXIMATE BASIN BOUNDARY ABOVE GAGING STATION

$F$ - $F$, LINE OF GENERALIZED HYDROGEOLOGIC SECTION

$Q^{9}$ SURFICIAL AQUIFER SYSTEM WELL AND NUMBER

$Q^{R}$ AGI-SH SURFICIAL AQUIFER SYSTEM WELL WITH CONTINUOUS RECORDER

$Q^{R}$ AGI-DP INTERMEDIATE AQUIFER SYSTEM WELL WITH CONTINUOUS RECORDER

A STREAMFLOW GAGING STATION

RAINFALL RECORDING GAGE

Figure 46. Location of Agrico-1 Creek basin, topography, data-collection network, and line of hydrogeologic section F-F'. 
The Agrico-9 Creek basin is blanketed by a thin layer of consolidated clay and an underlying layer of viscous clay ranging in thickness from approximately 2 to $40 \mathrm{ft}$. This viscous clay layer overlies a layer of overburden that is as much as $40 \mathrm{ft}$ thick. Water-level fluctuations in well AG9-DP reflect a pattern similar to that observed at the unmined basins. The difference between the water table in the surficial aquifer system and the potentiometric surface of the intermediate aquifer system ranges from 1 to $1.5 \mathrm{ft}$, indicating that the two systems are hydraulically connected.

The upper confining unit of the intermediate aquifer system was occasionally breached during mining operations, thereby permitting direct hydraulic connection with the surficial aquifer system. Water levels at wells CFI1-DP, AG4-DP, and AG1-DP generally were within $1 \mathrm{ft}$ of the levels in the overlying surficial aquifer system, indicating that the intermediate and surficial aquifer systems probably are connected and functioning as one unconfined aquifer in the area of these wells.

\section{EFFECTS OF LAND RECLAMATION ON STREAMFLOW}

Reclamation of a mined basin commonly alters the natural drainage pattern. The natural incised stream and dendritic drainage network commonly are replaced by swales or other poorly defined drainage features during reclamation. Whereas the soils of unmined basins tend to be well sorted and allow infiltration of rainfall and runoff, the soils of reclaimed basins commonly are less pervious because of the increased clay content. As a result, overland runoff commonly is greater and infiltration is smaller in reclaimed basins than in unmined basins.

The effects of land reclamation on streamflow characteristics are evaluated in this section and are based on comparisons of streamflow characteristics among unmined and reclaimed basins. In order to make comparisons between streams in basins with differing drainage areas, discharge is expressed in cubic feet per second per square mile $\left(\mathrm{ft}^{3} / \mathrm{s} / \mathrm{mi}^{2}\right)$.

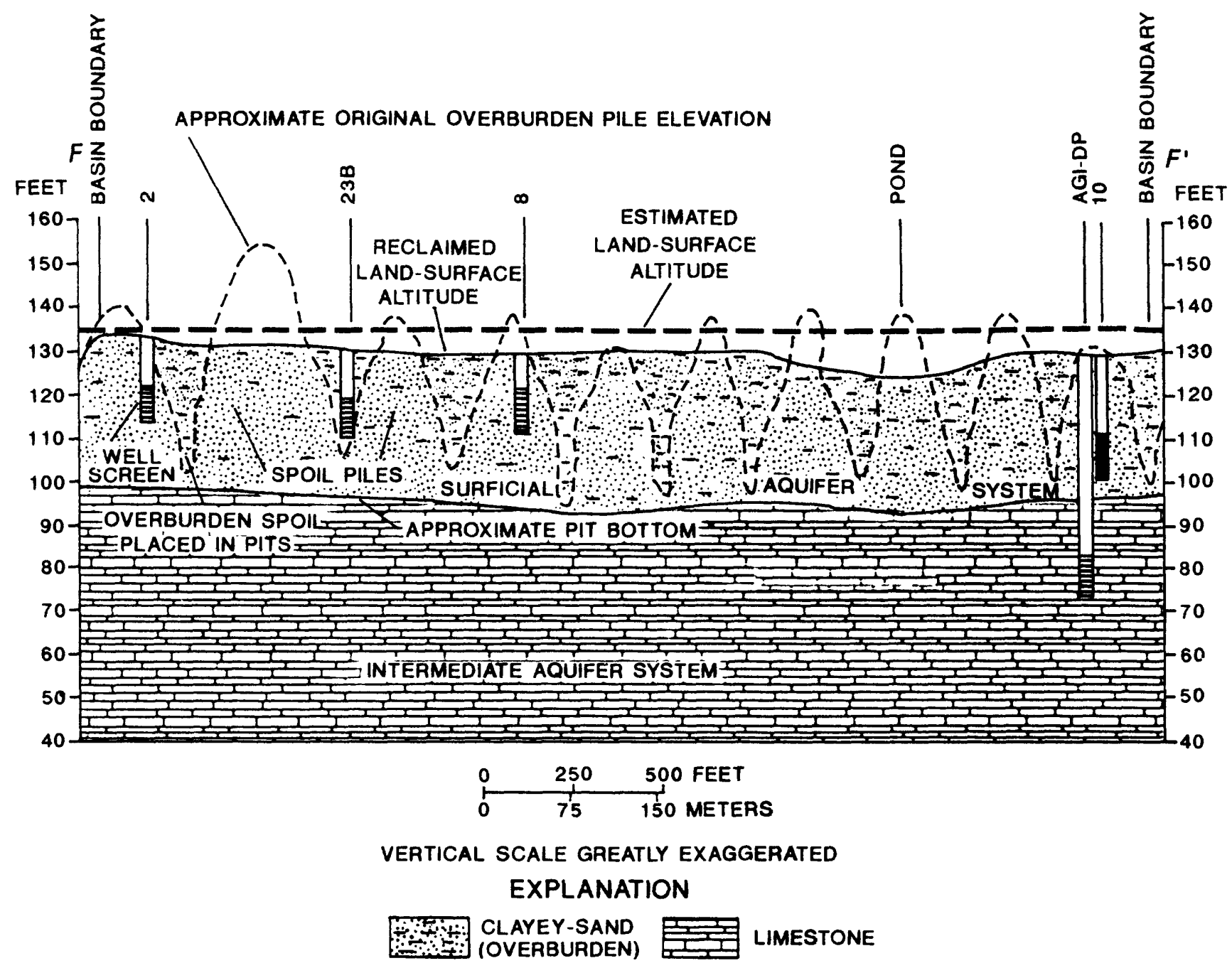

Figure 47. Hydrogeologic section F-F' at Agrico-1 Creek contoured-overburden basin. (Location of section is shown in fig. 46.) 


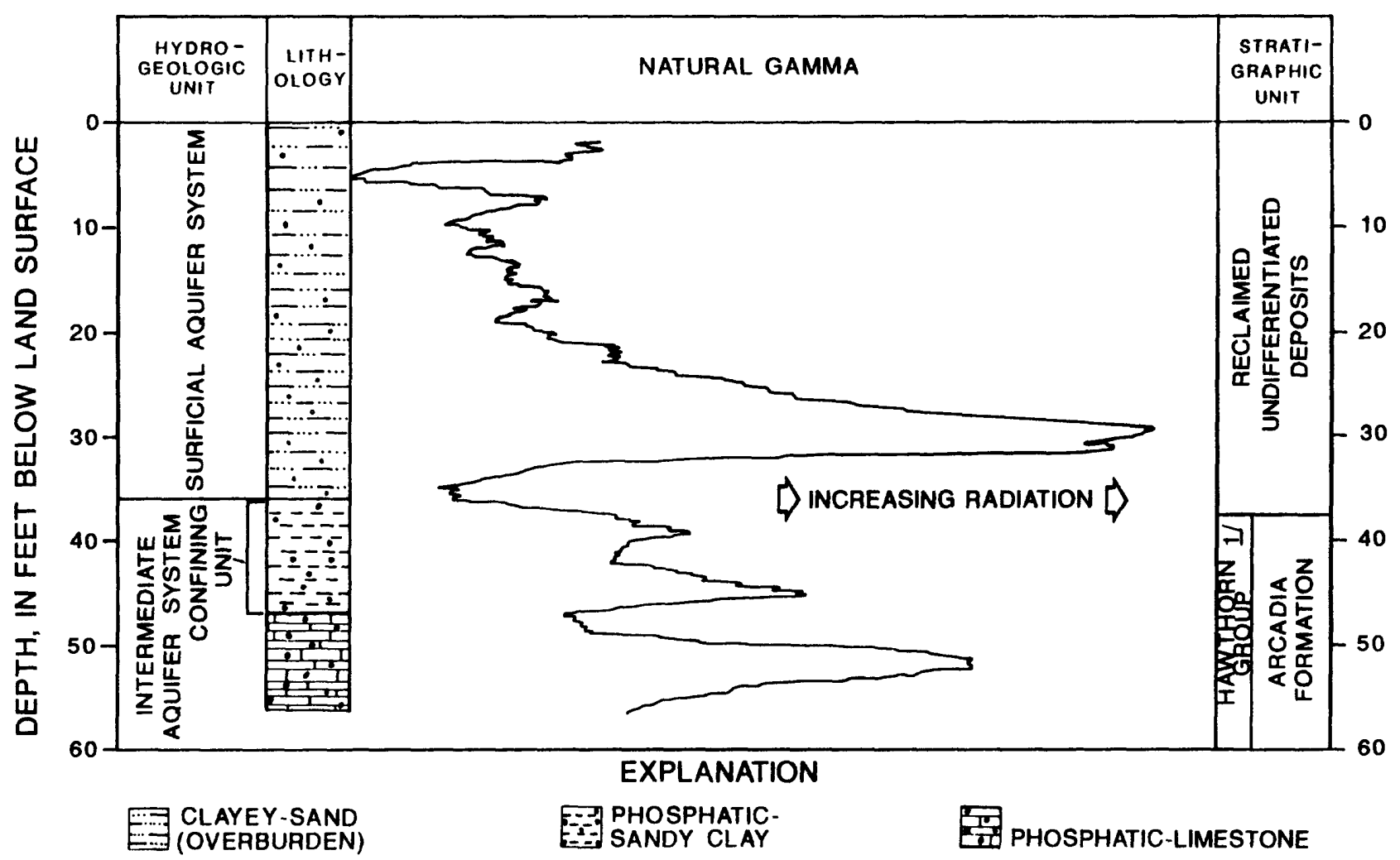

Figure 48. Hydrogeologic units, lithology, natural gamma-ray log, and stratigraphic units at well AG1-DP, completed in the intermediate aquifer system at the Agrico-1 Creek basin.

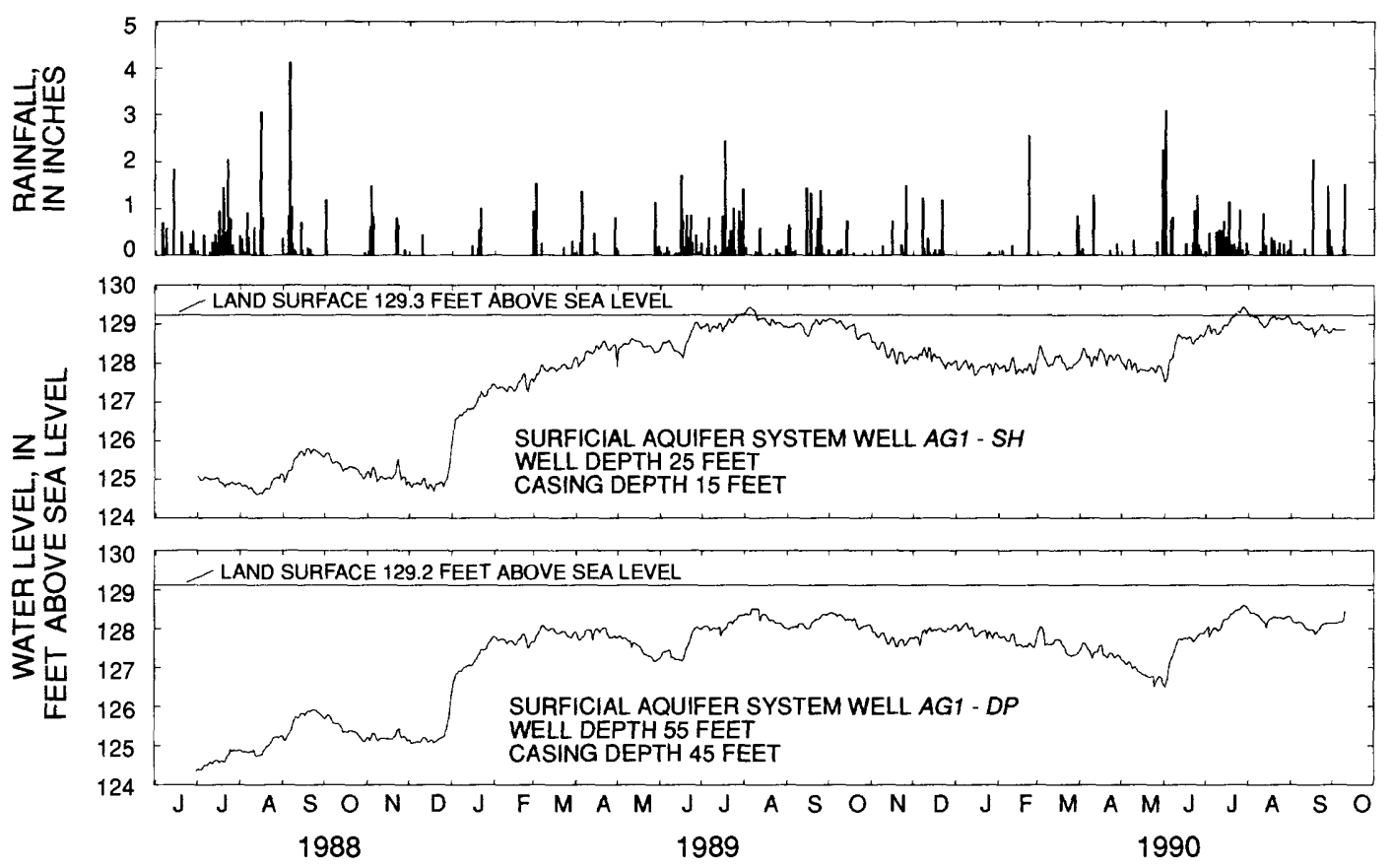

Figure 49. Daily rainfall and ground-water levels in monitor wells at Agrico-1 Creek basin, June 1988 to October 1990. 

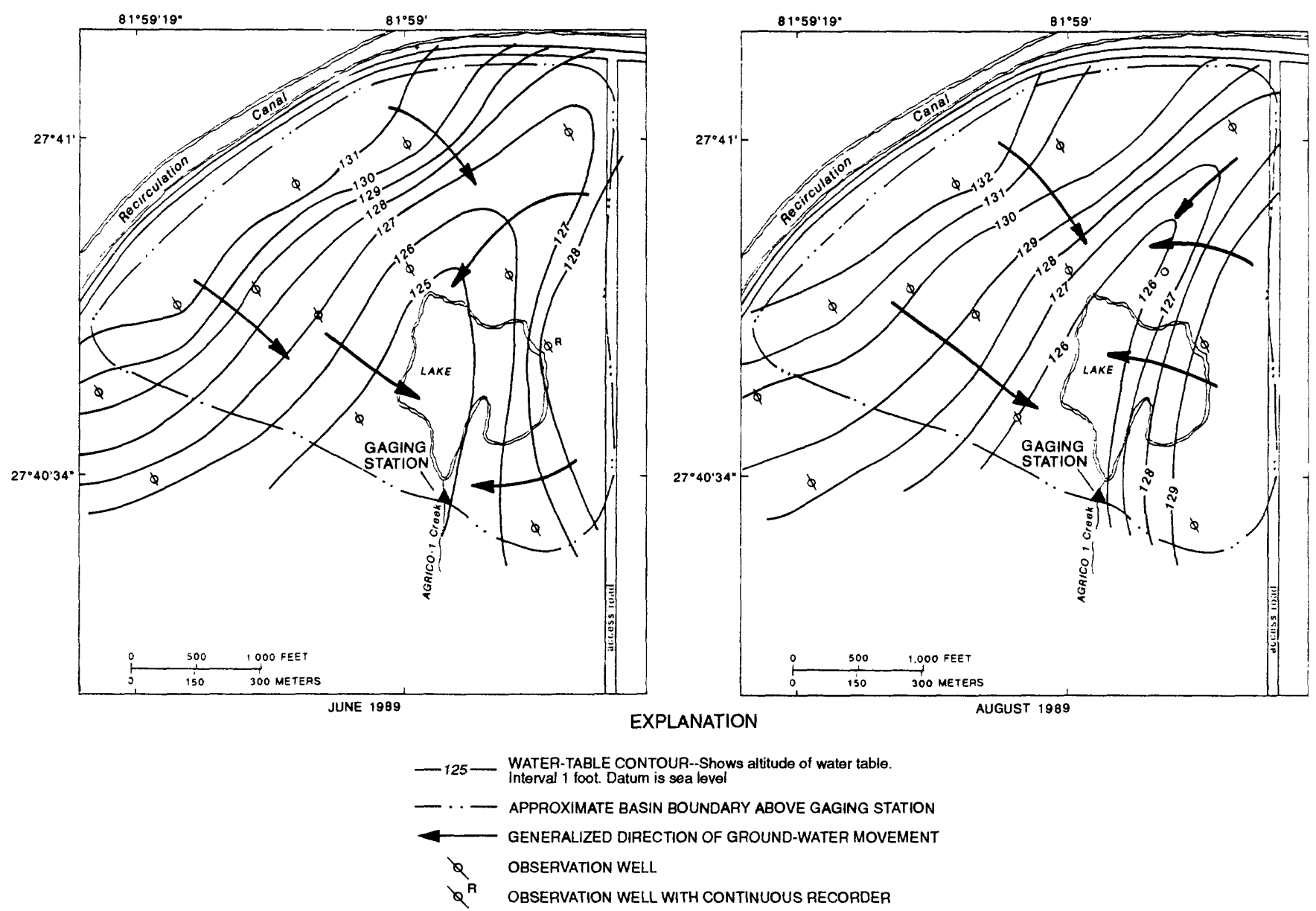

Figure 50. Configuration of the water table in the surficial aquifer system at the Agrico-1 Creek basin, June and August 1989.

Runoff, in inches of water over the basin, is used in this section to describe yield of a basin (Martin, Duwelius, and Crawford, 1990).

\section{Daily Mean Discharge}

Streamflow response to rainfall was similar among the study basins. Daily mean discharge per square mile (unit discharge) at the eight basins is shown in figure 54 . Discharge from the basins increased during the summer months (June through September) when thunderstorm activity was more prevalent. The peak discharges resulting from the thunderstorm of September 6, 1988, were the largest recorded during the study at four of the eight study basins. The smaller peaks during 1989-90 are attributed to storms during dryer conditions. The reclaimed basins, Agrico-1 Creek and Agrico-4 Creek, typically had the largest overall unit discharge; the smallest unit discharges were observed at Mobil Creek and CFI-3 Creek basins. Because of a loss or absence of data, the hydrographs for the Agrico-9 and CFI-1 Creek basins do not accurately represent their total discharge.

Streams in all of the study basins were intermittent and had extended periods of no-flow, especially during the spring dry period. Streamflow from the clay and sand-clay settling basins, Mobil Creek, Agrico-9 Creek, and CFI-1 Creek, occurred only during storms. The shape of the receding limb of the hydrographs in figure 54 reflects the runoff characteristics of the streams. The short-duration sharp peaks and rapid recessions of the Mobil Creek hydrograph indicate that runoff is quickly drained from the basin following a storm. Conversely, the slower return to base-flow conditions at the Agrico-1 Creek basin indicates that runoff is delayed because it is released more slowly. The magnitude of peak discharges typically varies among the basins because of the effects of various physical factors. Factors such as shape, length, and slope of the basin determine the timing of peak runoff. Rainfall intensity and distribution affect discharge volume and soil moisture, whereas soil type and surface topography affect overland runoff and ground-water contributions to streamflow.

\section{Discharge Duration}

The discharge-duration curves presented in this report are cumulative frequency curves that show the percentage of time that any given daily mean discharge was equaled or exceeded during 1988-90. The shape of the duration curve 


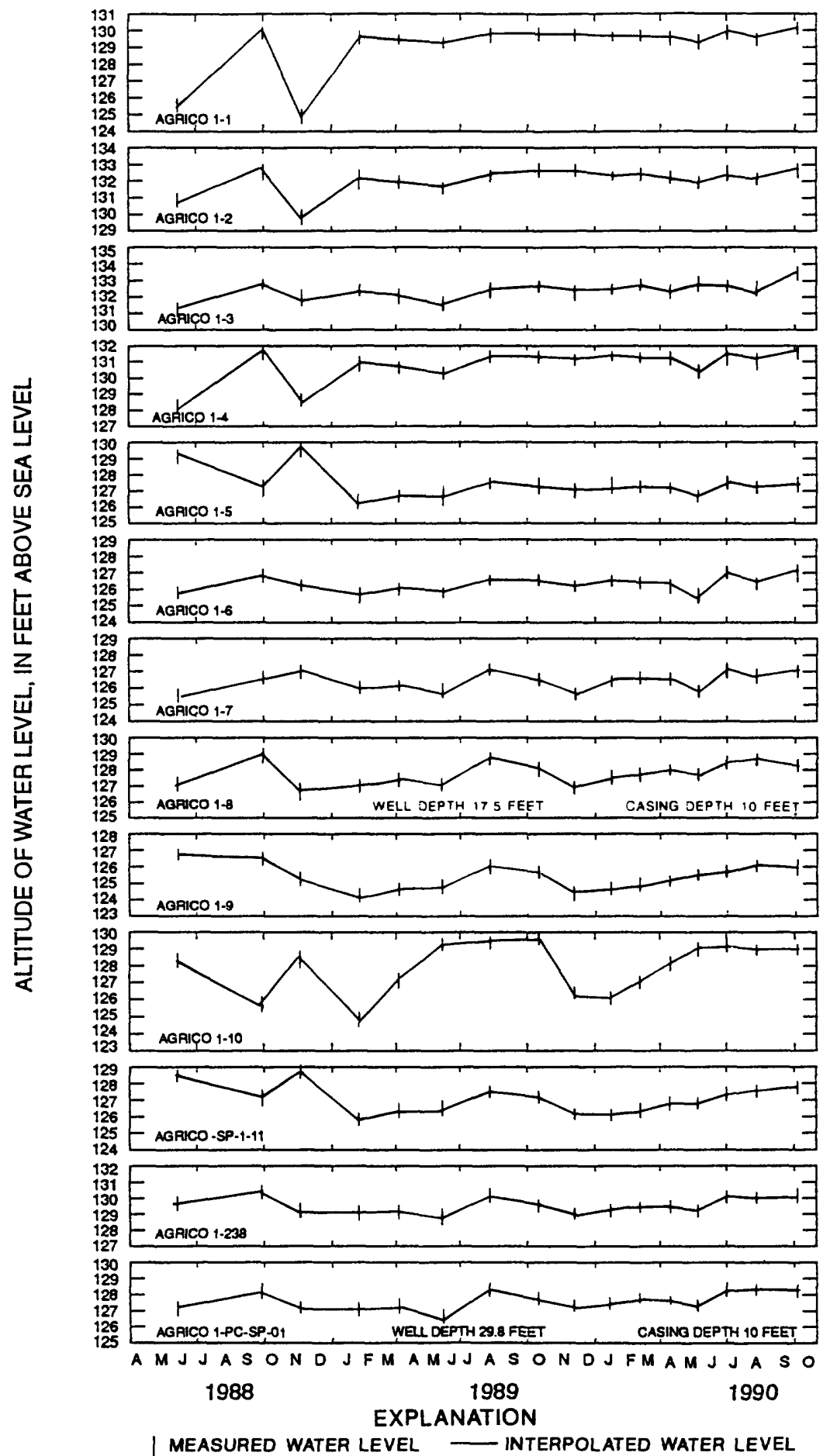

Figure 51. Water levels based on periodic measurements in wells completed in the surficial aquifer system at the Agrico-1 Creek basin, June 1988 to October 1990. 
indicates the flow characteristics throughout the range of discharge. The slope of the curve indicates the variability of flow. A steeply sloping curve indicates highly variable discharge, whereas a moderately sloping curve indicates a more stable discharge. Duration curves (fig. 55) were calculated for six basins that had daily mean discharge records for a period of 658 to 846 days (table 3 ). Duration curves were not calculated for the CFI-1 Creek and the Agrico-9 Creek basins because of periods of missing record.

Periods of no-flow at the unmined basins ranged from 47 percent of the time at CFI-3 Creek to 15 percent of the time at Grace Creek. Periods of no-flow at the reclaimed basins ranged from 91 percent of the time at Mobil Creek to 16 percent of the time at Agrico-4 Creek.
Daily mean discharges that were equaled or exceeded 1 percent of the time at the three unmined basins are as follows: IMC Creek, $7.8\left(\mathrm{ft}^{3} / \mathrm{s}\right) / \mathrm{mi}^{2}$; Grace Creek, 5.8 $\left(\mathrm{ft}^{3} / \mathrm{s}\right) / \mathrm{mi}^{2}$; and CFI-3 Creek, $5.5\left(\mathrm{ft}^{3} / \mathrm{s}\right) / \mathrm{mi}^{2}$ (fig. 55). The daily mean discharges equaled or exceeded 1 percent of the time at reclaimed basins Agrico-4 Creek and Agrico-1 Creek were $27.9\left(\mathrm{ft}^{3} / \mathrm{s}\right) / \mathrm{mi}^{2}$ and $28.6\left(\mathrm{ft}^{3} / \mathrm{s}\right) / \mathrm{mi}^{2}$, respectively. These discharges were significantly higher than those at the unmined basins. Of the six study basins, Mobil Creek basin had the smallest daily mean discharge that was equaled or exceeded 1 percent of the time, $2.6\left(\mathrm{ft}^{3} / \mathrm{s}\right) / \mathrm{mi}^{2}$.

The extremes in daily mean discharge at the eight basins are listed in table 3 . Daily mean discharge records at two of the reclaimed basins, Agrico-9 Creek and CFI-1

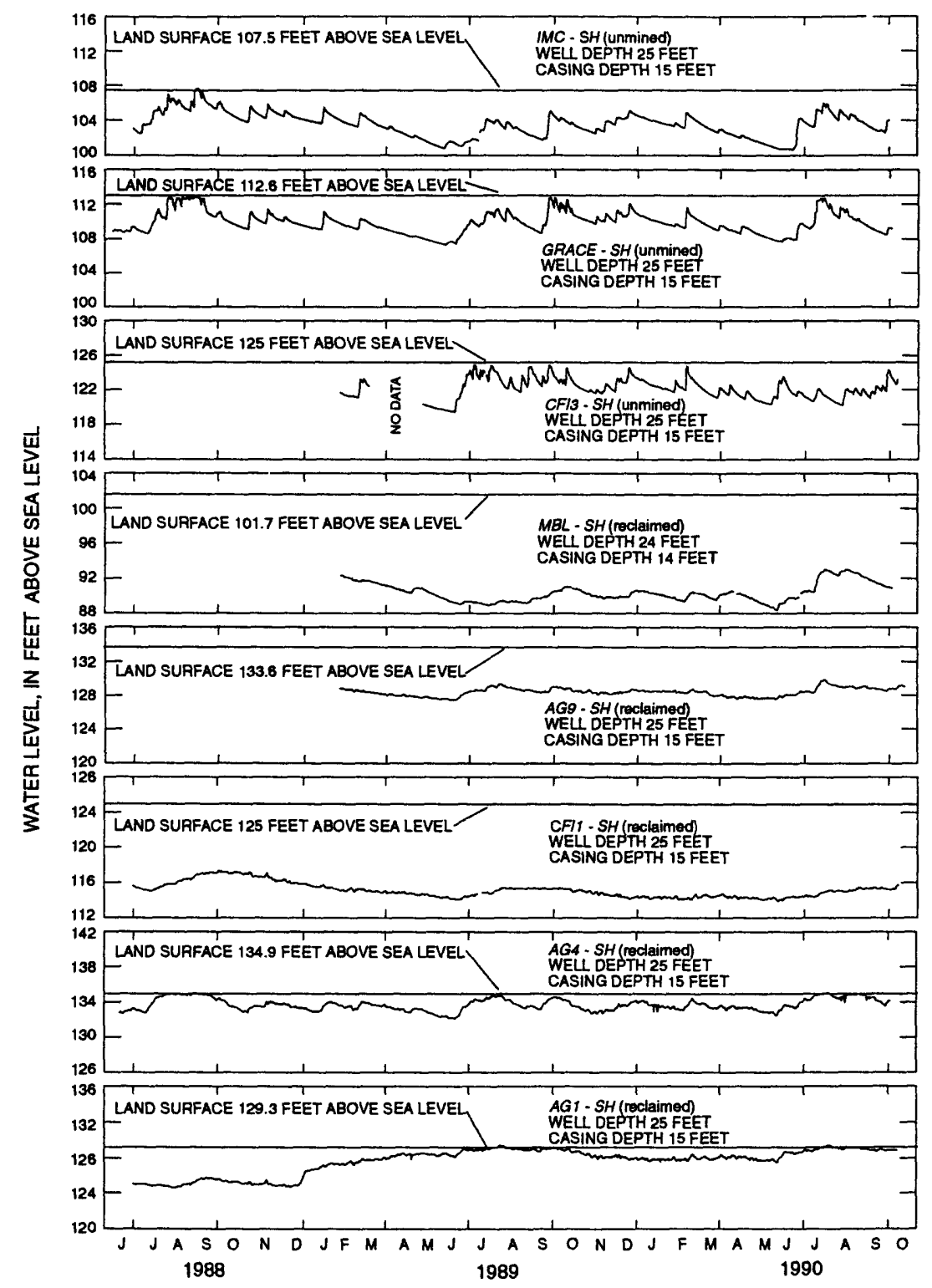

Figure 52. Water levels in monitor wells completed in the surficial aquifer system at the eight study basins, June 1988 to October 1990. 


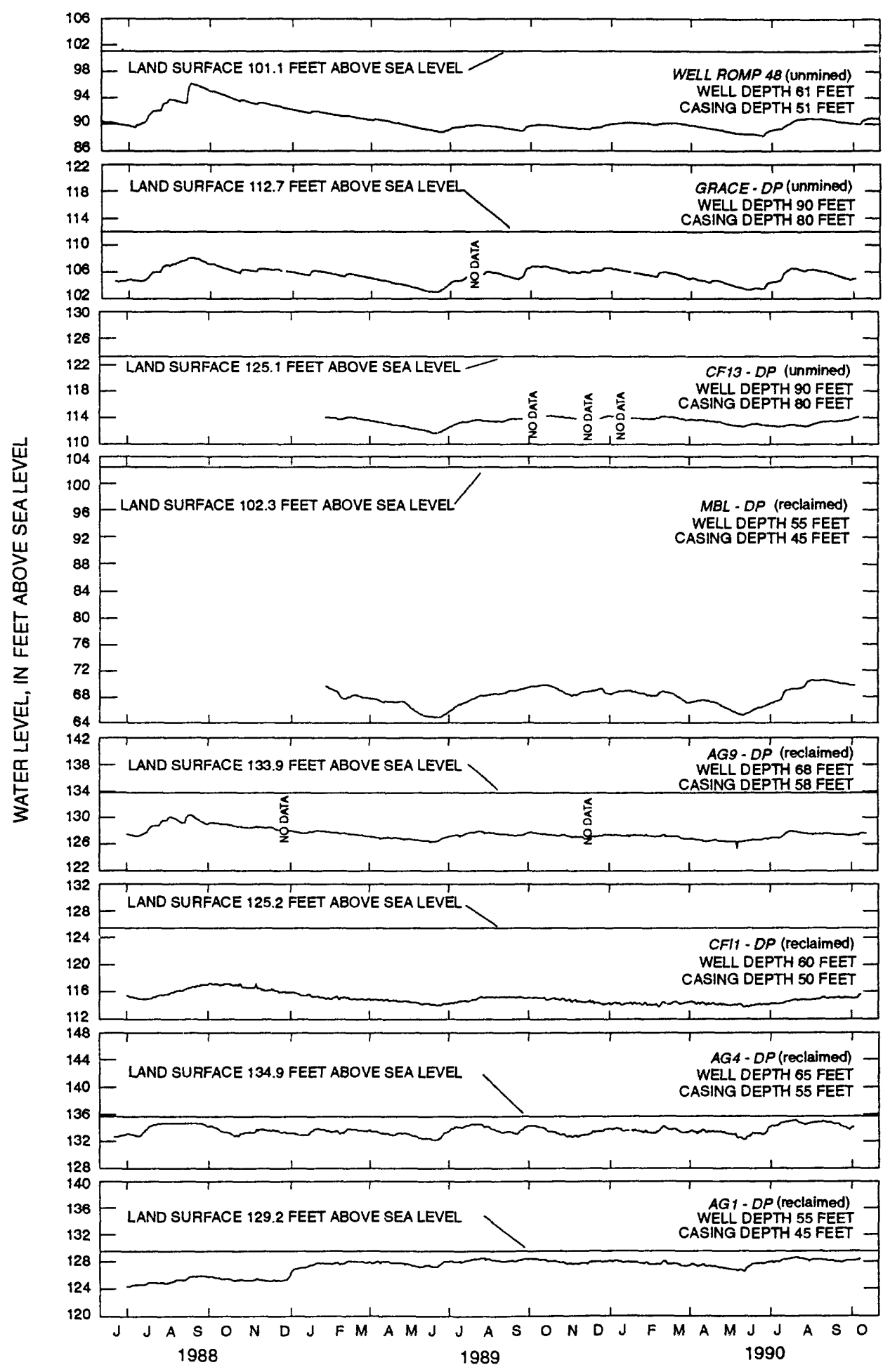

Figure 53. Water levels in monitor wells completed in the intermediate aquifer system at the eight study basins, June 1988 to October 1990. 

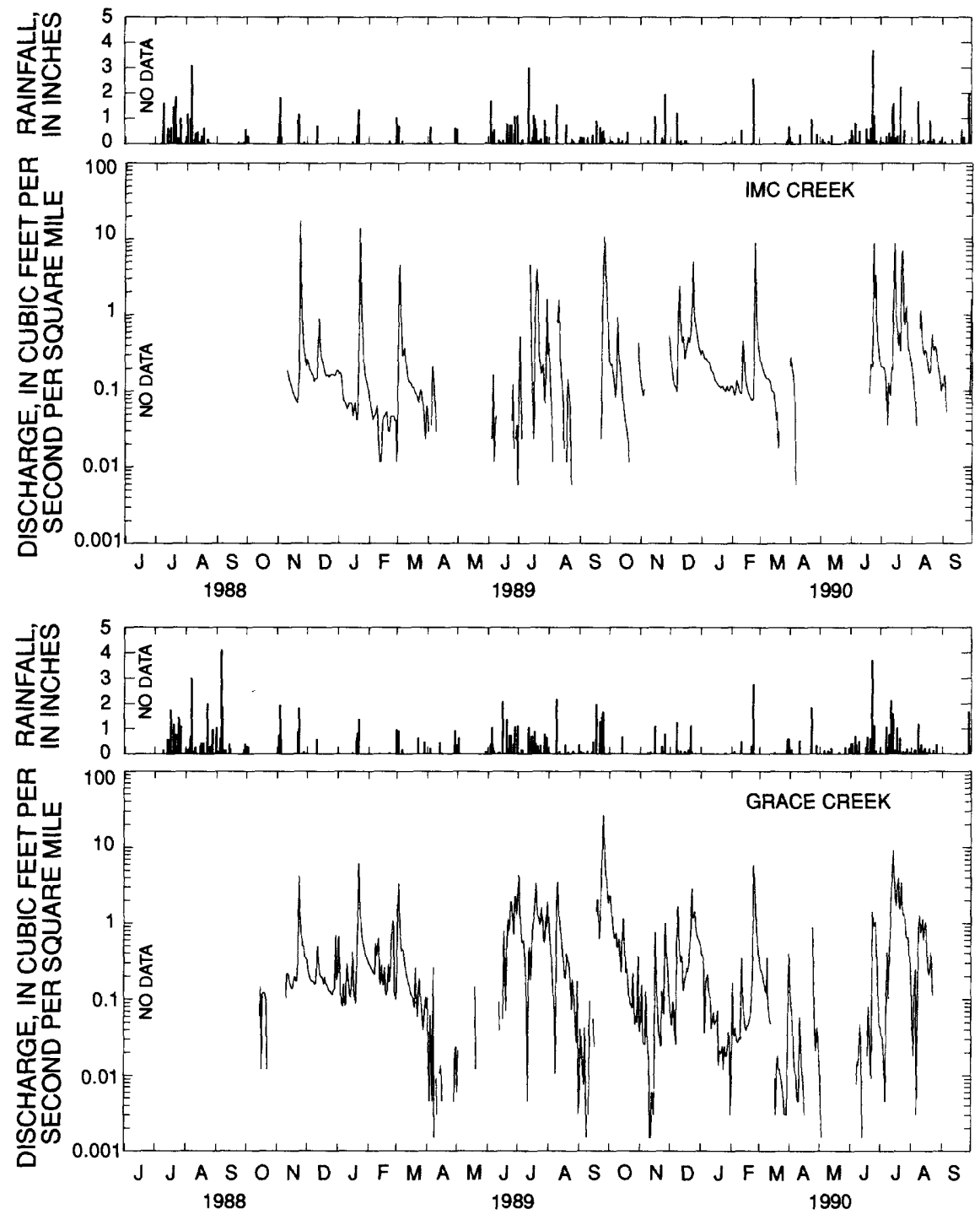

Figure 54. Daily rainfall and daily mean discharge, June 1988 to September 1990, at the eight study basins.

Creek, are incomplete and may not accurately reflect the true characteristics of the basin. The five largest daily mean discharges generally occurred at Agrico-4 Creek and Agrico-1 Creek basins. The maximum daily mean discharges at CFI-3 Creek, Mobil Creek, CFI-1 Creek, and Agrico-1 Creek basins were similar for the thunderstorm event of September 6-7, 1988. The largest flows generally occurred following thunderstorm activity during the summer months.

Mobil Creek and CFI-3 Creek basins had the greatest number of days with no-flow, followed by Agrico-1 Creek and IMC Creek basins. Agrico-4 Creek and Grace Creek basins had the least number of no-flow days, indicating a greater contribution to base flow from ground water. Insufficient data were available for Agrico-9 Creek and CFI-1 Creek basins to make a comparison of flow characteristics.

Comparisons of monthly rainfall and runoff between basins from 1988 to 1990 can be made using figure 56 . The largest monthly rainfall occurred as a result of local convective thunderstorms during the summer months of June through September. Rainfall amounts during the remaining months were typically the result of winter frontal storms. Although monthly runoff varied among the unmined and the reclaimed basins, runoff volumes at Agrico-4 Creek, Agrico-1 Creek, and Grace Creek were similar. IMC Creek and CFI 3 Creek also had similar runoff volumes. Monthly runoff volumes at Mobil Creek were small or nonexistent.

\section{Maximum Peak Discharges}

Comparison of maximum peak discharges for the eight study basins indicates that the three highest peak discharges recorded during the study occurred following a thunderstorm on September 6, 1988. Peak discharges of $500\left(\mathrm{ft}^{3} / \mathrm{s}\right) / \mathrm{mi}^{2}$ 

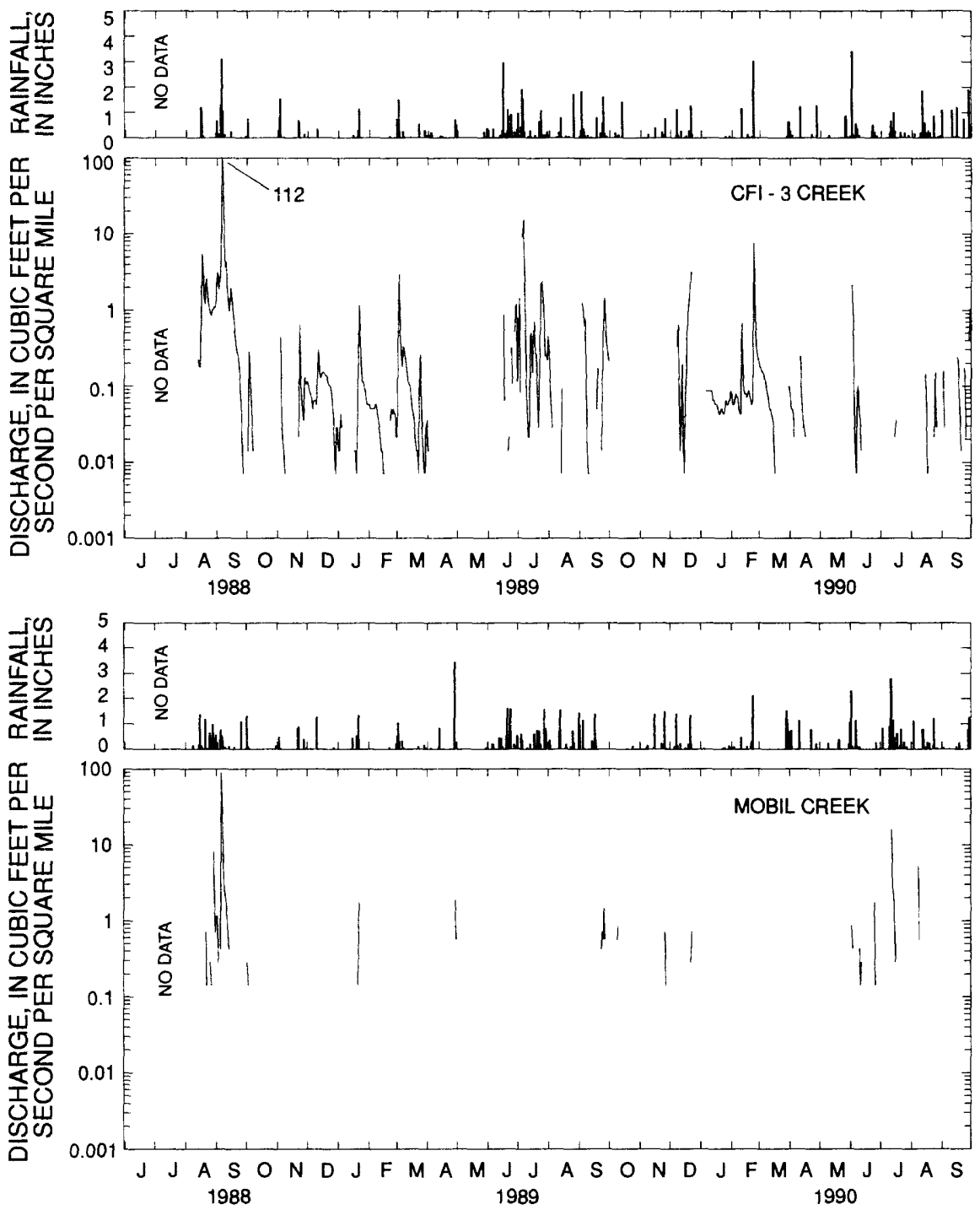

Figure 54.(Continued) Daily rainfall and daily mean discharge, June 1988 to September 1990, at the eight study basins.

occurred at Mobil Creek, $448\left(\mathrm{ft}^{3} / \mathrm{s}\right) / \mathrm{mi}^{2}$ at CFI-3 Creek, and $352\left(\mathrm{ft}^{3} / \mathrm{s}\right) / \mathrm{mi}^{2}$ at CFI-1 Creek (table 4). Peak discharges associated with the thunderstorm of September 6, 1988, probably were the highest peaks in all the basins during the study period, but these peaks were not recorded at IMC Creek, Grace Creek, and Agrico-9 Creek because the streamflow-gaging stations had not yet been installed. High peak discharges also were recorded during an intense storm on September 26-27, 1989.

Frequent and intense summer thunderstorms, which produce about 60 percent of the annual rainfall, commonly result in high peak discharges. Low-intensity, long-duration frontal storms that typically move through west-central Florida during the winter months generate moderate to large peak discharges. Of the eight study basins, the Agrico-9 Creek basin generally had the lowest peak discharges because of the surface storage capacity in the basin. The Mobil Creek basin, which is a clay-settling basin with little or no depressional storage, had the highest peak discharge measured during the study.

\section{Rainfall-Runoff Relations}

The efficiency with which water is transported overland from the basins is shown by the hydrographs in figures 57 and 58. The two general storm classifications, thunderstorms and frontal storms, have differing precipitation patterns and result in different streamflow hydrographs. Hydrographs of runoff from thunderstorms usually have sharper peaks with faster rising and falling limbs of the curve than do hydrographs for runoff from frontal storms. 

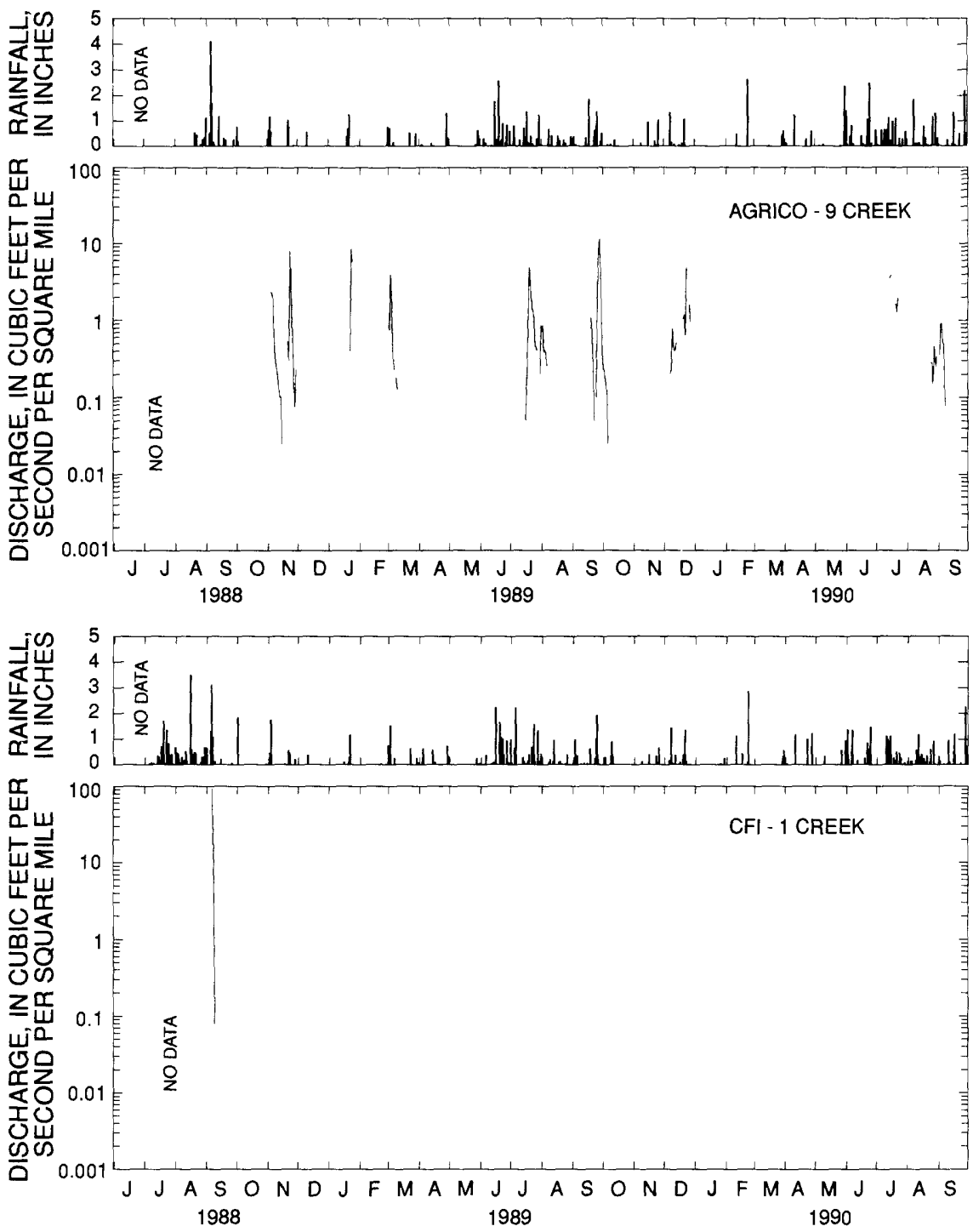

Figure 54.(Continued) Daily rainfall and daily mean discharge, June 1988 to September 1990, at the eight study basins.

Hydrographs for the unmined basins that have a well-defined drainage network, IMC Creek, Grace Creek, and CFI-3 Creek, generally were characterized by well-defined peaks that rise and fall sharply. The hydrographs for the reclaimed basins, Agrico-9 Creek, Agrico-4 Creek, and Agrico-1 Creek, had much broader peaks, indicating that runoff from these basins generally was slow to reach a maximum peak and slow to recede.

Ten typical storms (five thunderstorms and five frontal storms) were selected to evaluate the relation of runoff to rainfall for the study basins. Comparisons of storm hydrographs were made among the basins whenever sufficient data were available. A small number of relatively large-magnitude storms occurred during the study period, but the effects of a regional drought reduced overall runoff volumes. The five summer convective thunderstorms selected were intense within the narrow path of the storm. The selected thunderstorms occurred on September 6-8, 1988, July 18-20, 1989, September 24-27, 1989, June 2-3, 1990, and July 12-13, 1990 (fig. 57). The frontal storms selected produced similar rainfall totals throughout the study area and occurred on November 3-6, 1988, November 22-24, 1988, January 21-24, 1989, March 1-4, 1989, and February 23-24, 1990 (fig. 58).

The total volume of storm runoff for each of the 10 storms was calculated using the hydrograph separation method described by Rouse (1950). This method calculates total runoff for a particular storm by separating the various components of the unit hydrograph, such as base flow and storm runoff. The base-flow component was either insignificant or absent in most storm runoff hydrograph analyses. The lack of base flow in unmined basins during some periods is the result of the bottom of the channel being above the water table. 

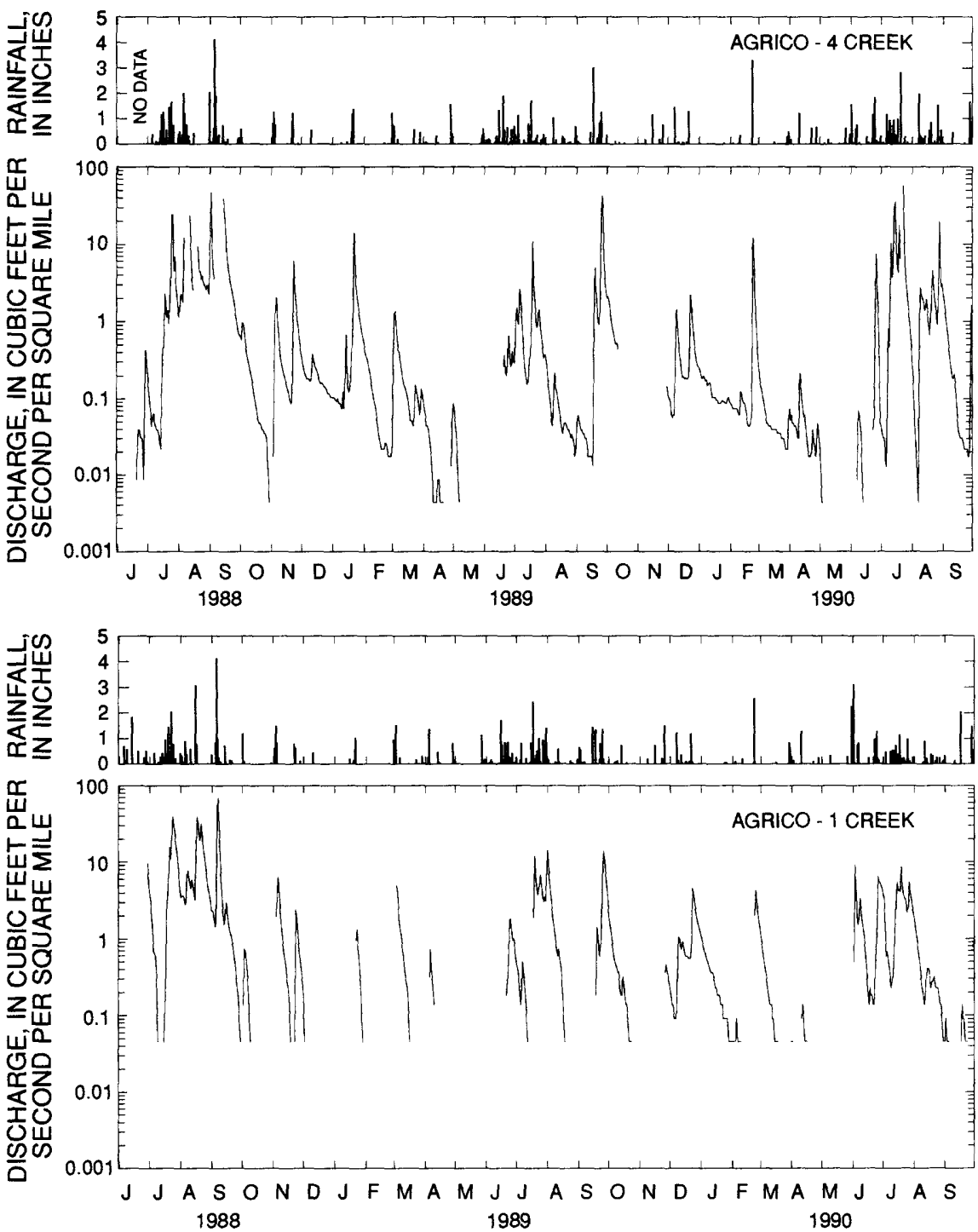

Figure 54.(Continued) Daily rainfall and daily mean discharge, June 1988 to September 1990, at the eight study basins.

The largest rainfall totals for a single storm were 5.53 and 6.43 in. (table 4) on September 6-8, 1988, at CFI-1 Creek and Agrico-1 Creek basins, respectively. The greatest rainfall intensities, however, occurred during the thunderstorm of June 2-3, 1990, when as much as 3 in. of rain fell during a 1-hour period at the CFI-3 Creek basin (table 4). The smallest rainfall totals used in this analyses occurred during the frontal storm on March 1-4, 1989, and ranged from 0.95 to 1.90 in. (table 5).

The largest runoff coefficients (volume of runoff divided by volume of rainfall) resulted from the thunderstorms of September 6-8, 1988, and September 24-27, 1989 (table 4). The large runoff coefficients were the result of intense rainfall near the end of the summer rainy season when the soil was saturated. The larger runoff coefficients during a given storm generally were for the reclaimed basins where the reworked overburden had become less permeable because of the redistribution of the clay and sand. The largest runoff coefficient ( 96.9 percent) was the result of the thunderstorm of September 6-8, 1988, at the CFI-1 Creek (sand-clay settling) basin (table 4). The smallest runoff coefficient ( 0.64 percent) was the result of the storm of March 1, 1989, at the Mobil Creek (clay-settling) basin (table 5).

The reclaimed areas generally exhibited the longest basin response time from initial rise to peak discharge (figs. 57 and 58). The small size, sloping land surface, and low permeability of surface soils of the Mobil Creek clay-settling basin resulted in this basin having the fastest runoff response. The larger clay-settling basin, Agrico-9 Creek, which has little topographic relief and numerous surface depressions that store water, had the longest runoff time. This comparison illustrates the differences in runoff characteristics between two reclaimed basins backfilled with the same type of material. 

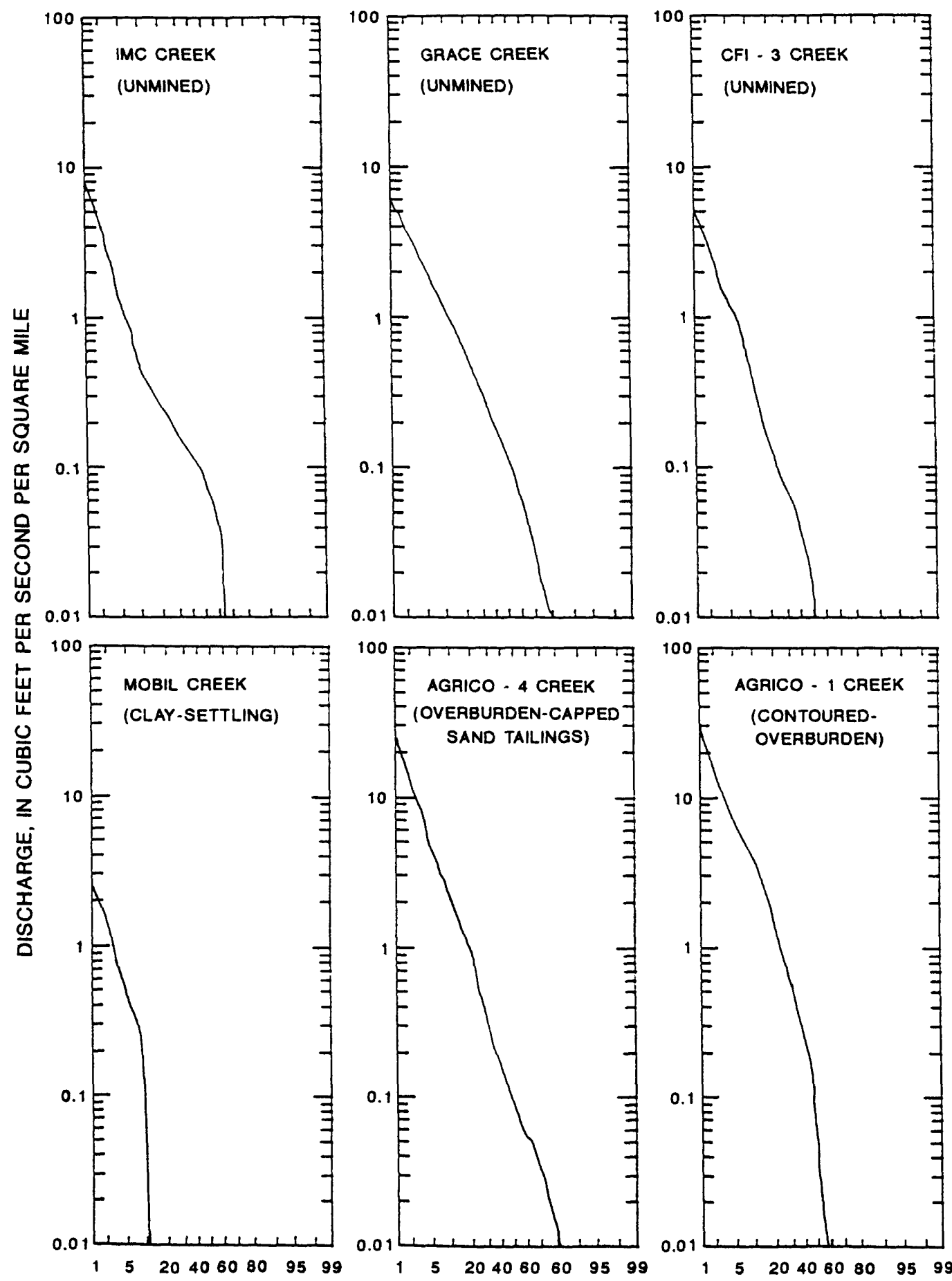

PERCENT OF TIME DAILY MEAN DISCHARGE WAS EQUALED OR EXCEEDED

Figure 55. Duration curves of daily mean discharge at six study basins, 1988-90. 
Table 3. Extremes of daily mean discharge at the eight study basins $\left[\left(\mathrm{ft}^{3} / \mathrm{s}\right) / \mathrm{mi}^{2}\right.$, cubic feet per second per square mile]

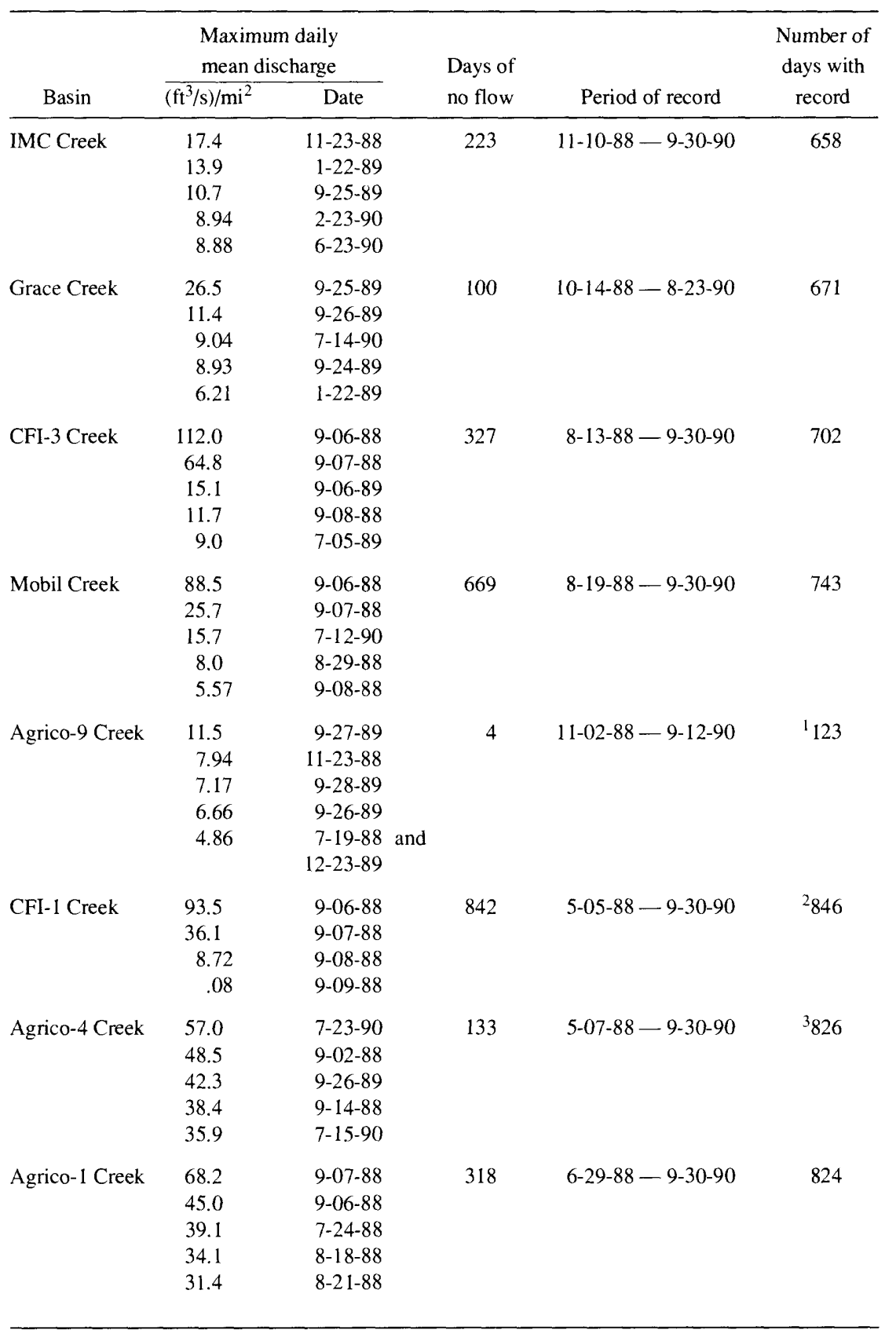

${ }^{1}$ Incomplete record.

${ }^{2}$ Flow occurred on only 4 days (September 6-9, 1988) during the 846 days of data collection.

${ }^{3}$ Due to backwater conditions, 17 days were excluded from analysis. 
SヨHONI NI ' $\exists J O N \cap Y$
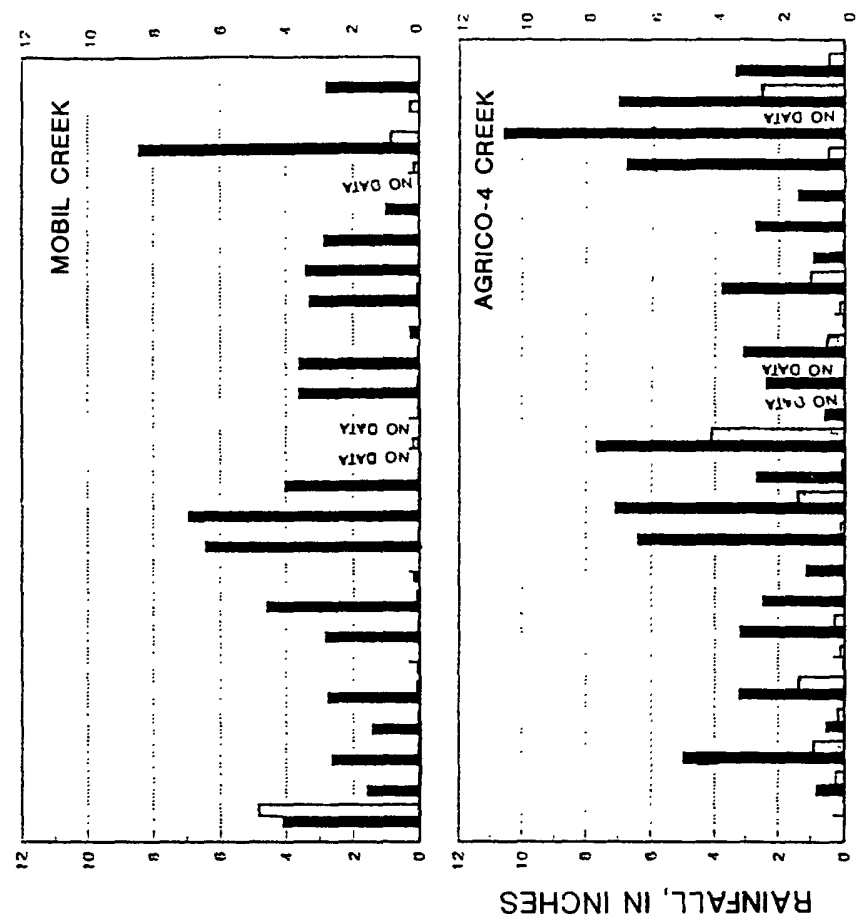

SヨHONI NI' $J J O N \cap Y$

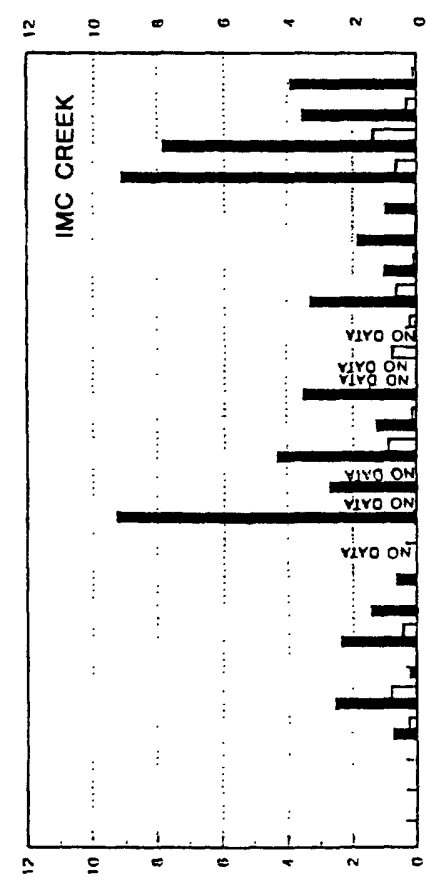

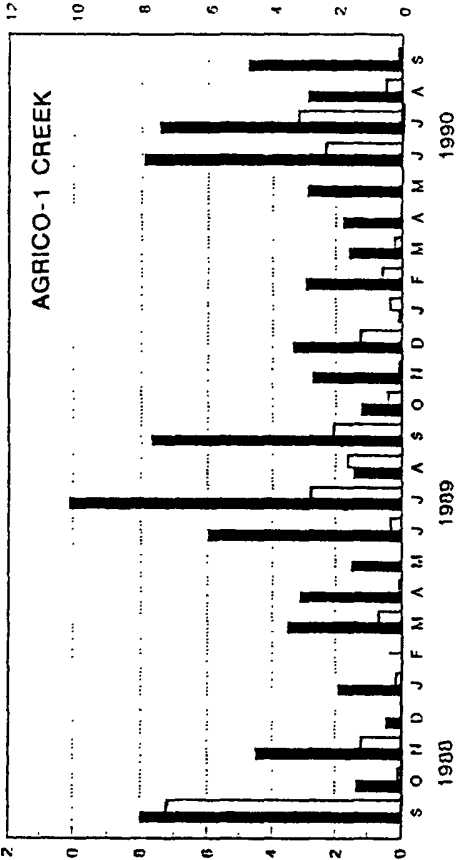

岂

을

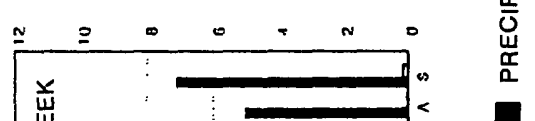

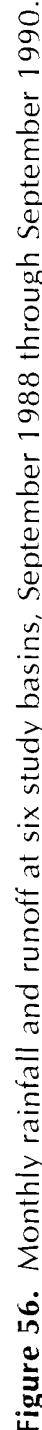


Table 4. Peak discharge, rainfall, and runoff during typical thunderstorms in the west-central Florida phosphate-mining region, 1988-90

$\left[\left(\mathrm{ft}^{3} / \mathrm{s}\right) / \mathrm{mi}^{2}\right.$, cubic feet per second per square mile; --, no data]

\begin{tabular}{|c|c|c|c|c|c|c|c|c|c|}
\hline \multirow[b]{2}{*}{ Basin } & \multirow{2}{*}{$\begin{array}{c}\text { Peak } \\
\text { discharge } \\
{\left[(\mathrm{ft} 3 / \mathrm{s}) / \mathrm{mi}^{2}\right]}\end{array}$} & \multirow{2}{*}{$\begin{array}{l}\text { Rainfall } \\
\text { (inches) }\end{array}$} & \multirow{2}{*}{$\begin{array}{l}\text { Storm } \\
\text { runoff } \\
\text { (inches) }\end{array}$} & \multirow{2}{*}{$\begin{array}{c}\text { Runoff } \\
\text { coefficient }^{2} \\
\text { (percent) }\end{array}$} & \multirow{2}{*}{$\begin{array}{l}\text { Time } \\
\text { from } \\
\text { rise } \\
\text { to peak } \\
\text { (hours) }\end{array}$} & \multicolumn{2}{|c|}{$\begin{array}{l}\text { Maximum rainfall } \\
\text { intensity for } \\
\text { indicated periods } \\
\text { (inches) }\end{array}$} & \multicolumn{2}{|c|}{$\begin{array}{l}\text { Rainfall during } \\
\text { indicated number of } \\
\text { days previous to storm } \\
\text { (inches) }\end{array}$} \\
\hline & & & & & & 15 minutes & 1 hour & 3 days & 7 days \\
\hline \multicolumn{10}{|c|}{ September 6-8, 1988} \\
\hline $\begin{array}{r}\text { CFI-3 Creek } \\
\text { (unmined) }\end{array}$ & 448 & -- & -- & -- & 7.25 & -- & -- & -- & -- \\
\hline $\begin{array}{l}\text { Mobil Creek } \\
\text { (clay-settling) }\end{array}$ & 500 & -- & -- & -- & -- & -- & -- & -- & -- \\
\hline $\begin{array}{l}\text { CFI-1 Creek } \\
\text { (sand-clay settling) }\end{array}$ & 352 & 5.53 & 5.36 & 96.93 & 8.25 & 0.70 & 1.41 & 0.00 & 1.86 \\
\hline $\begin{array}{l}\text { Agrico-1 Creek } \\
\text { (contoured- } \\
\text { overburden) }\end{array}$ & 109 & 6.43 & 5.89 & 91.60 & 8.00 & .28 & .64 & .03 & .52 \\
\hline \multicolumn{10}{|c|}{ July $18-20,1989$} \\
\hline $\begin{array}{l}\text { IMC Creek } \\
\text { (unmined) }\end{array}$ & 10.5 & 1.55 & .25 & 16.13 & 3.00 & .46 & .83 & 1.47 & 4.47 \\
\hline $\begin{array}{r}\text { Grace Creek } \\
\text { (unmined) }\end{array}$ & 5.82 & 1.43 & .19 & 13.29 & 3.75 & .71 & .35 & 1.44 & 2.28 \\
\hline $\begin{array}{l}\text { Agrico-9 Creek } \\
\text { (clay-settling) }\end{array}$ & 7.17 & 2.82 & .58 & 20.57 & 15.50 & .88 & 1.38 & .96 & 1.25 \\
\hline $\begin{array}{l}\text { Agrico-1 Creek } \\
\text { (contoured- } \\
\text { overburden) }\end{array}$ & 13.6 & 2.93 & 1.08 & 36.86 & 5.25 & 1.26 & 2.42 & .89 & 1.1 \\
\hline $\begin{array}{l}\text { Agrico-4 Creek } \\
\text { (overburden-capped } \\
\text { sand-tailings) }\end{array}$ & 17.7 & 1.79 & .53 & 29.61 & 8.75 & .64 & 1.18 & 1.16 & 1.39 \\
\hline \multicolumn{10}{|c|}{ September 24-27, 1989} \\
\hline $\begin{array}{l}\text { IMC Creek } \\
\text { (unmined) }\end{array}$ & 29.7 & 2.18 & .75 & 34.40 & 2.75 & .14 & .29 & .00 & .90 \\
\hline $\begin{array}{r}\text { Grace Creek } \\
\text { (unmined) }\end{array}$ & 72.0 & 3.40 & 1.55 & 45.59 & 10.50 & .81 & 1.03 & 1.87 & 4.43 \\
\hline $\begin{array}{l}\text { Agrico-9 Creek } \\
\text { (clay-settling) }\end{array}$ & 14.3 & 2.85 & 1.11 & 38.95 & 58.75 & .77 & 1.32 & .41 & 2.49 \\
\hline $\begin{array}{l}\text { Agrico-4 Creek } \\
\text { (overburden-capped } \\
\text { sand-tailing) }\end{array}$ & 99.6 & 3.38 & 3.09 & 91.42 & 3.75 & .75 & 1.22 & .60 & 3.62 \\
\hline $\begin{array}{l}\text { Agrico-I Creek } \\
\text { (contoured- } \\
\text { overburden) }\end{array}$ & 16.8 & 3.14 & 1.48 & 47.13 & 9.00 & .48 & .72 & .17 & 1.05 \\
\hline \multicolumn{10}{|c|}{$\underline{\text { June } 2-3,1990}$} \\
\hline $\begin{array}{r}\text { CFI-3 Creek } \\
\text { (unmined) }\end{array}$ & 44.3 & 3.52 & .11 & 3.12 & 1.25 & 1.28 & 3.08 & .06 & 1.78 \\
\hline $\begin{array}{l}\text { Mobil Creek } \\
\text { (clay-settling) }\end{array}$ & 17.2 & 2.40 & .05 & 2.08 & 1.00 & .22 & .85 & 1.24 & 1.24 \\
\hline $\begin{array}{l}\text { Agrico-I Creek } \\
\text { (contoured- } \\
\text { overburden) }\end{array}$ & 11.8 & 3.15 & .64 & 20.32 & 5.75 & .97 & 2.59 & 2.26 & 2.5 \\
\hline \multicolumn{10}{|c|}{ July $12-13,1990$} \\
\hline $\begin{array}{r}\text { Grace Creek } \\
\text { (unmined) }\end{array}$ & 23.0 & 2.32 & .20 & 8.62 & 2.50 & .73 & 2.01 & .95 & 2.04 \\
\hline $\begin{array}{l}\text { Mobil Creek } \\
\text { (clay-settling) }\end{array}$ & 143 & 3.07 & .64 & 20.85 & .75 & 1.05 & 1.84 & .92 & .92 \\
\hline
\end{tabular}

'Storm runoff is computed as the total runoff minus the base flow, in inches.

${ }^{2}$ Runoff coefficient is storm runoff volume divided by rainfall volume multiplied by 100 percent. 
SEPTEMBER 6-8, 1988
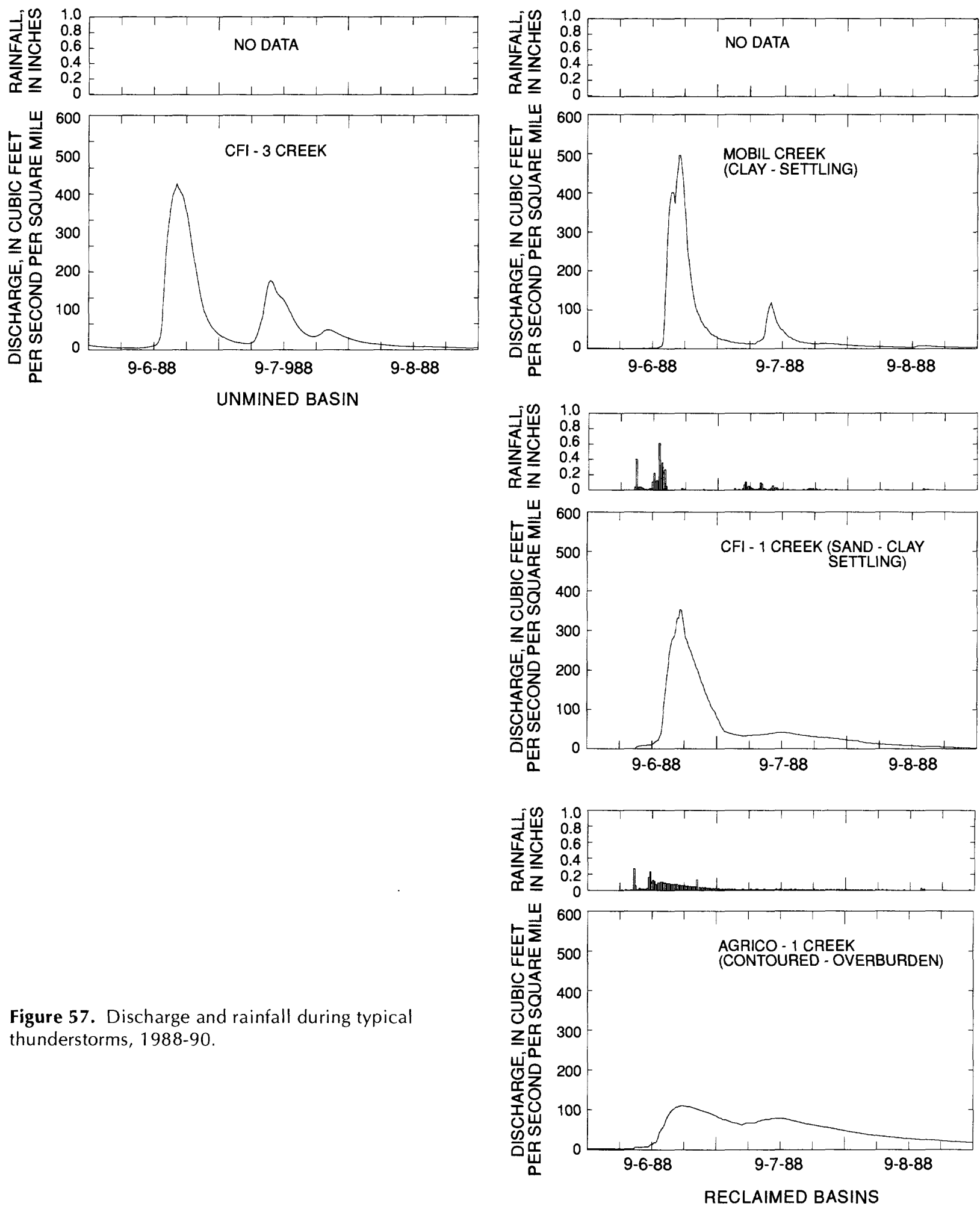
JULY 18-20, 1989
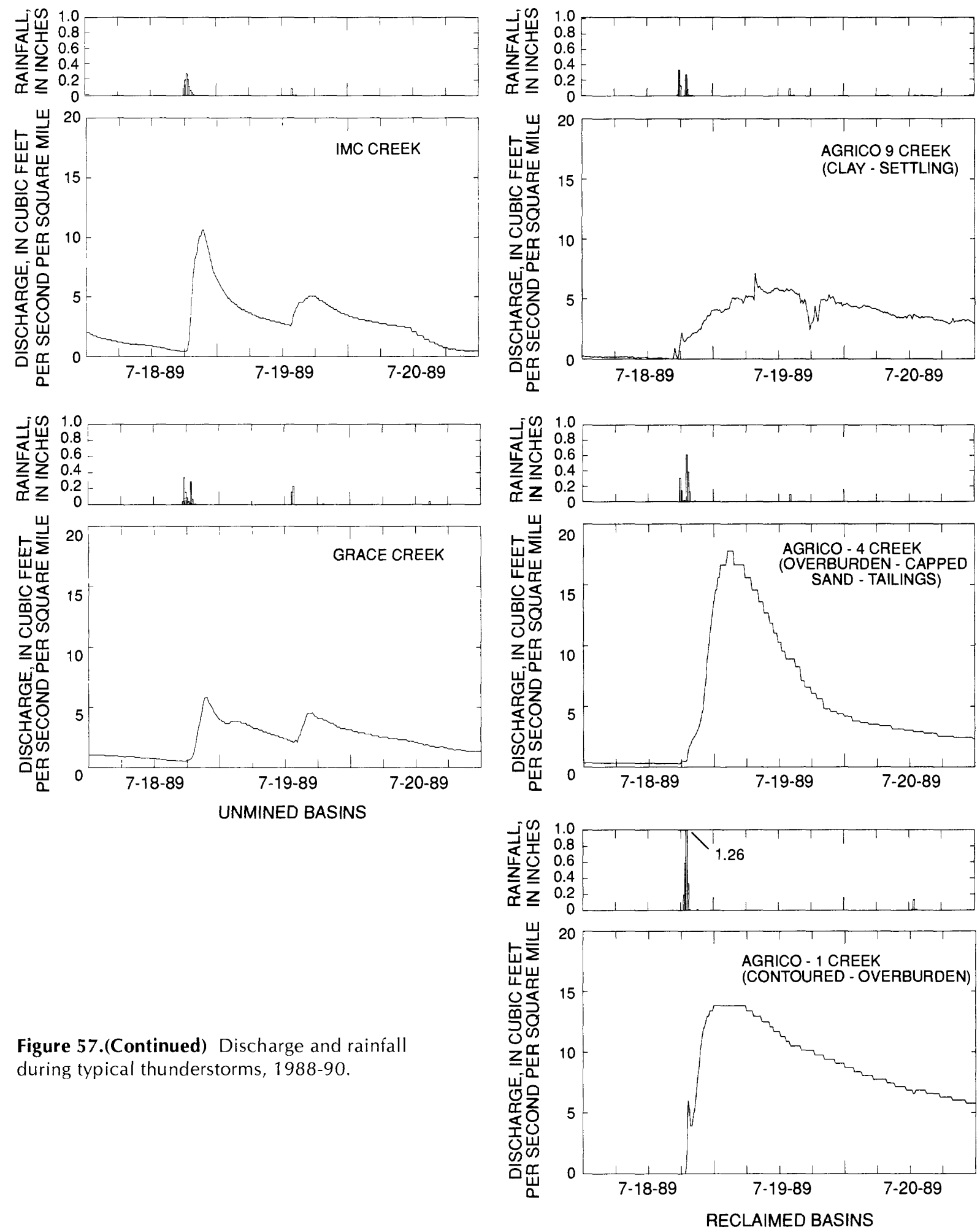

Figure 57.(Continued) Discharge and rainfall during typical thunderstorms, 1988-90. 
SEPTEMBER 24-27, 1989
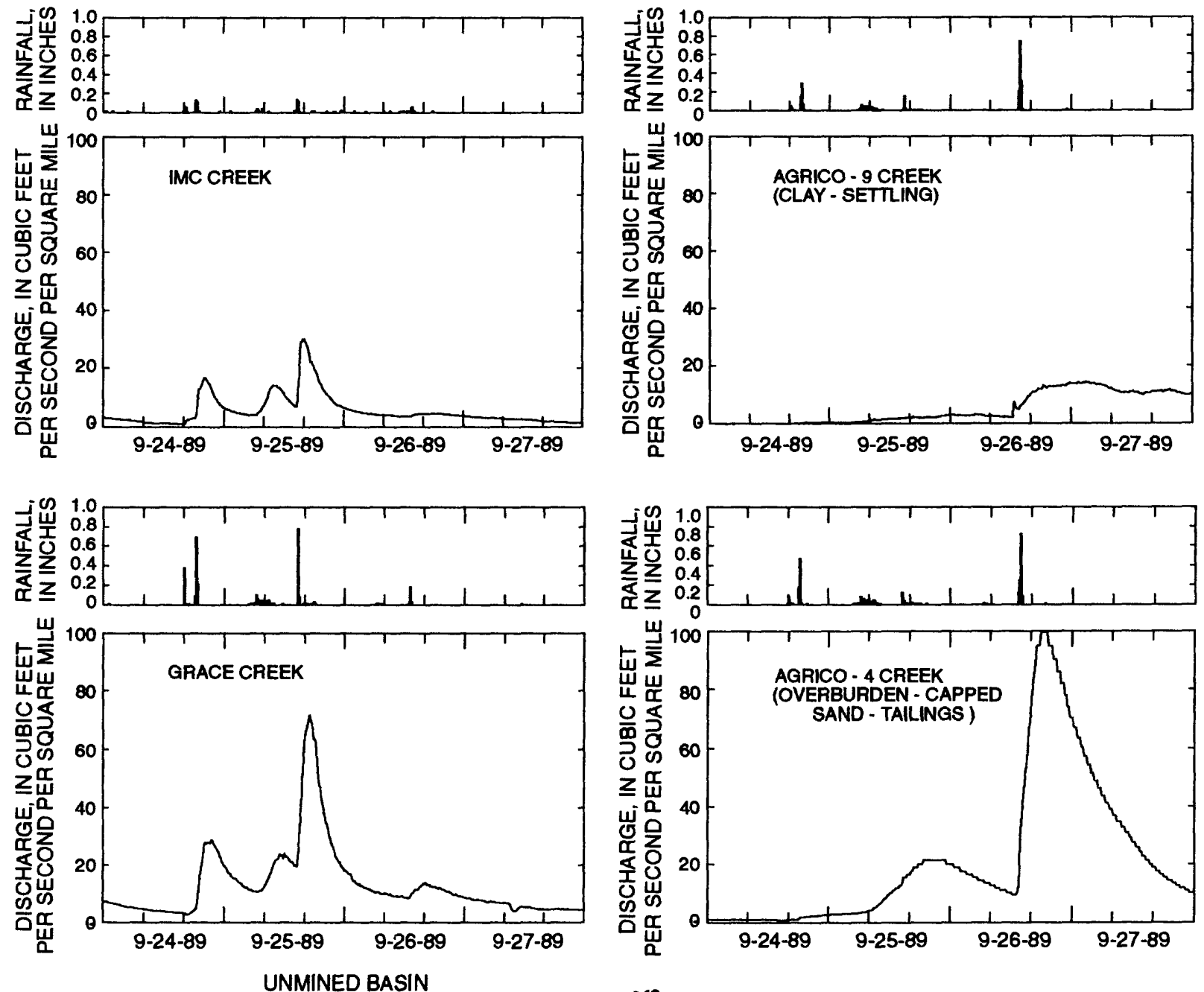

Figure 57.(Continued) Discharge and rainfall during typical thunderstorms, 1988-90.

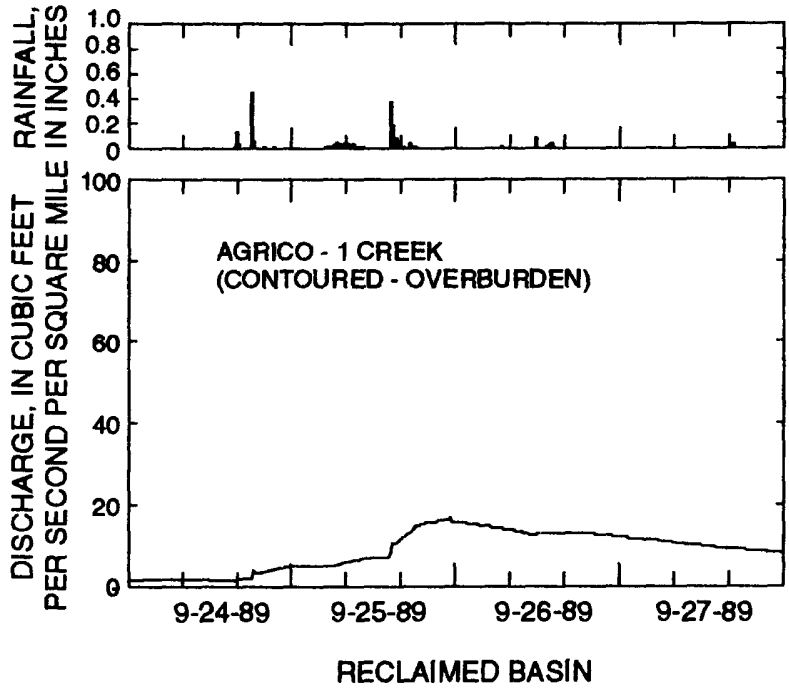



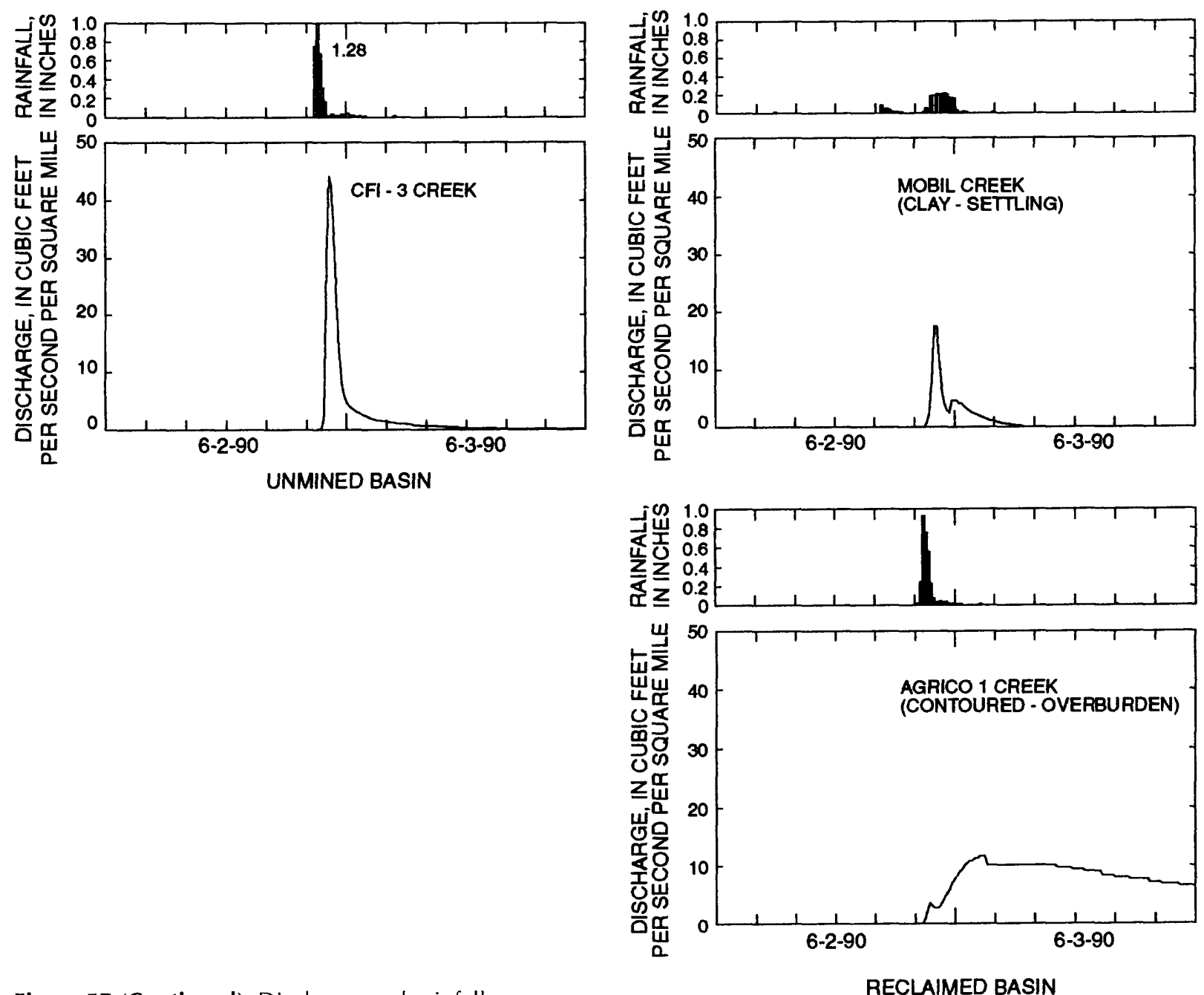

Figure 57.(Continued) Discharge and rainfall

RECLAIMED BASIN during typical thunderstorms, 1988-90.

JULY 12-13, 1990
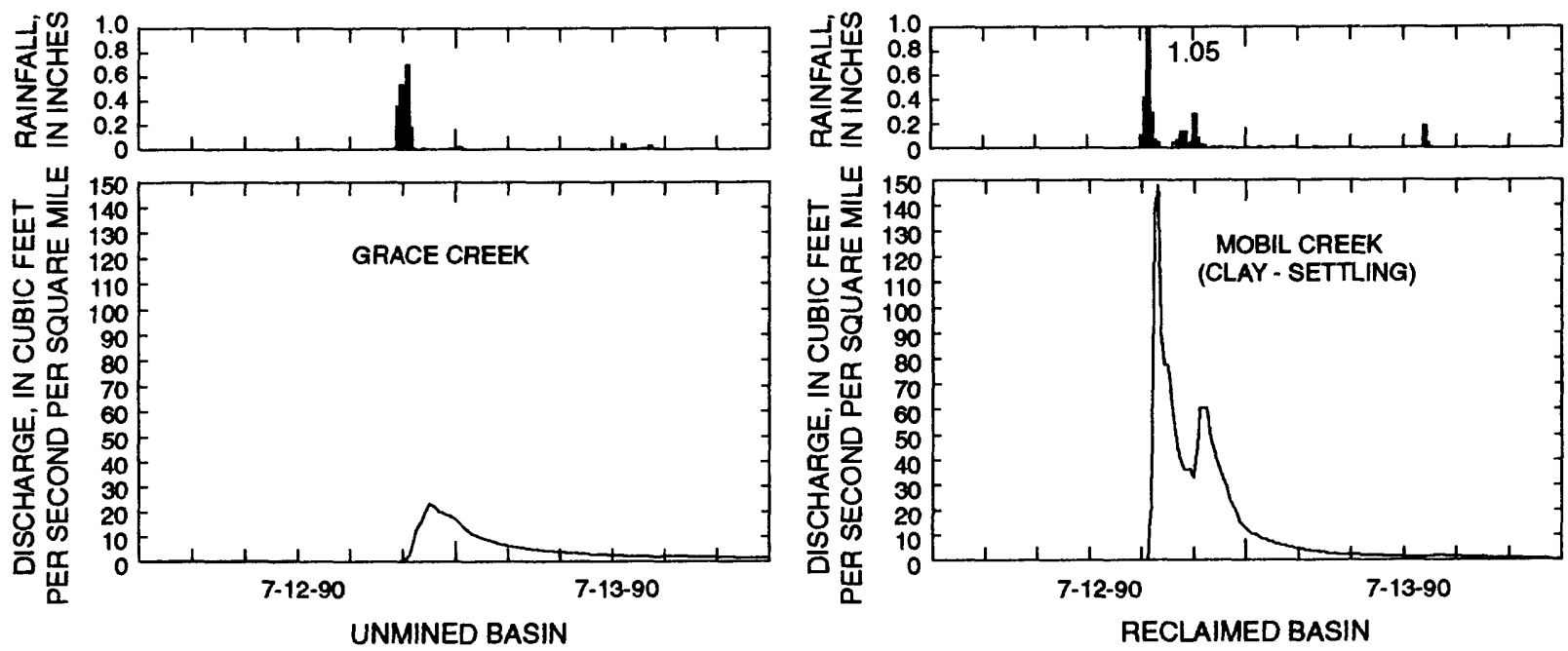

Figure 57.(Continued) Discharge and rainfall during typical thunderstorms, 1988-90. 


\section{WATER-QUALITY}

The State of Florida has established regulations that classify the waters of the State for specific categories of use and set standards for the quality of water for these uses. Classification of the waters of the State is based on potential as well as current use of the water. The classification and water-quality standards are described in the Florida Administrative Code, chapters 17-3, 17-320, and 17-550. In the following discussion of water quality in the study area, concentrations of selected constituents in water samples collected during this study are compared to the maximum contaminant levels established for primary and secondary drinking water standards for ground water and class I or III standards for surface water (Florida Department of Environmental Regulation, 1992). Class I surface waters are potable water supplies and class III surface waters are classified for recreation and the propagation and maintenance of a healthy fish and wildlife population.

Water-quality sampling during this study involved reconnaissance sampling and bimonthly sampling of surface and ground waters in the eight study basins. Reconnaissance samples of surface runoff and ground water in the study basins were collected for chemical analysis at the beginning of the study. These samples were collected from streams in each basin during both base-flow conditions (ground-water discharge) and during periods of high streamflow. Water samples also were collected from surficial aquifer system wells in November 1988. The samples were analyzed for chemical constituents, including major dissolved ions, trace elements, nutrients, and radiochemicals. In addition to the reconnaissance samples, water samples were collected bimonthly from streams and from wells completed in the surficial and intermediate aquifer systems. These samples were analyzed for alkalinity, chloride, sulfate, specific conductance, $\mathrm{pH}$, orthophosphorus, and dissolved solids. Water samples from streams in the basins also were analyzed for suspended solids. A portable, stage-activated, automatic water-quality sampler was used at selected basins to collect samples over a range of streamflow stages.

\section{Water in the Surficial Aquifer System}

Results of water-quality analyses of water from the surficial aquifer system at the eight study basins are presented in tables 6 and 7 . The quality of ground water in the three unmined basins, IMC Creek, Grace Creek, and CFI-3 Creek, represents natural background water quality. Results of water-quality analyses of samples from the reclaimed basins generally indicated that shallow ground water in these basins had higher concentrations of most constituents than did shallow ground water in unmined basins. Specific conductance of water samples collected bimonthly ranged from 75 to $217 \mu \mathrm{S} / \mathrm{cm}$ at the unmined basins and from 177 to $905 \mu \mathrm{S} / \mathrm{cm}$ at the reclaimed basins (table 7). Concentrations of dissolved solids in water samples collected from wells within the eight basins were below the Florida Department of Environmental Regulation (FDER) secondary drinking water standard of $500 \mathrm{mg} / \mathrm{L}$, except at the Mobil Creek basin where the ground water had a dissolvedsolids concentration of $686 \mathrm{mg} / \mathrm{L}$ (table 7). Dissolved-solids concentrations generally were greater in ground-water samples from the reclaimed basins than in samples from the unmined basins. Dissolved-solids concentrations based on residue after evaporation ranged from 34 to $107 \mathrm{mg} / \mathrm{L}$ in samples from the three unmined basins and from 117 to $686 \mathrm{mg} / \mathrm{L}$ in samples from the five reclaimed basins. The color of water was below the FDER secondary drinking water standard of $15 \mathrm{Pt}$-Co units in samples from five of the six basins sampled for analysis of color. The color of water from the surficial aquifer system at the Mobil Creek basin was 35 Pt-Co units and exceeded the standard.

The ranges of selected properties and constituent concentrations in samples collected bimonthly at the eight study basins are shown in boxplot diagrams in figure 59 and are listed in table 7 . The diagrams show the variation in values of selected properties and concentrations of constituents among the sites. Ground water at the unmined basins is characterized by relatively low specific conductance, alkalinity, and dissolved-solids concentration when compared with theground water at most of the reclaimed basins. Differences in values or concentrations for the other properties or constituents between unmined and reclaimed basins generally are small. 
NOVEMBER 3-6, 1988
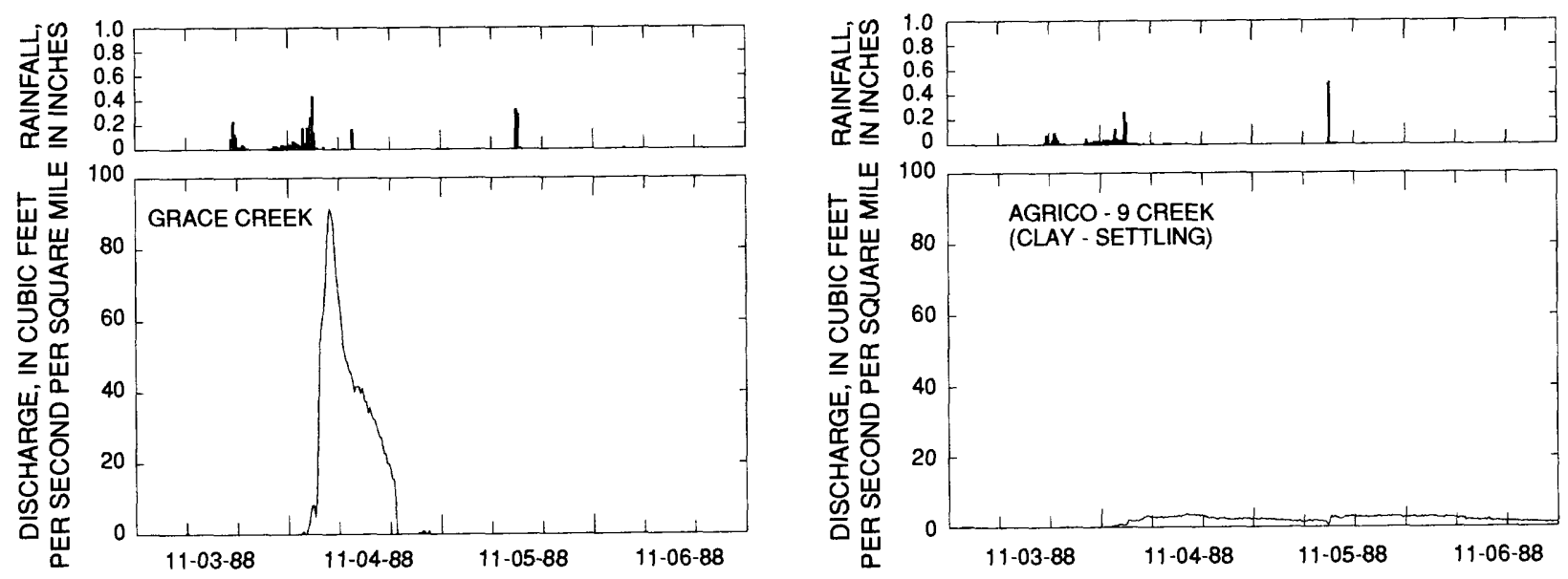

Figure 58. Discharge and rainfall during typical frontal storms, 1988-90.

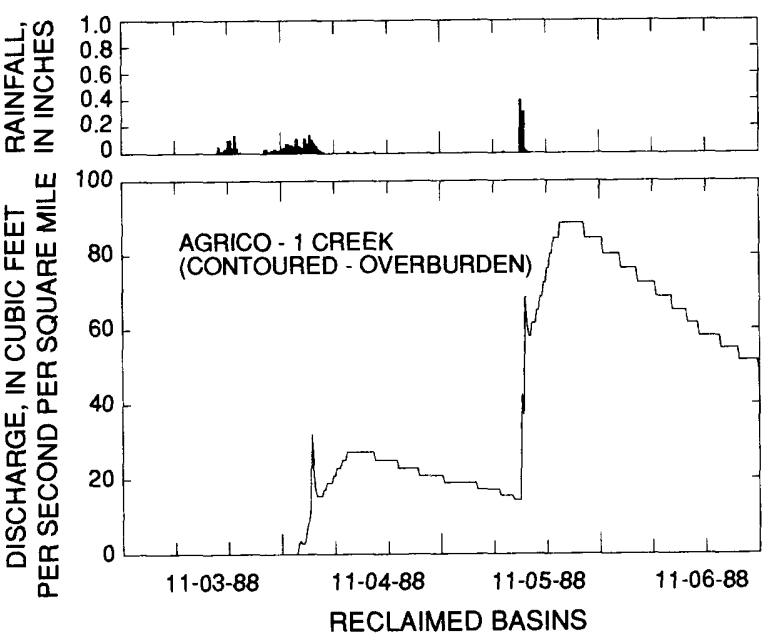




\section{Nitrogen and Phosphorus}

Nitrogen compounds in water samples from the surficial aquifer system included nitrite and nitrate, ammonia, and organic nitrogen. Concentrations of dissolved nitrite and nitrate $\left(\mathrm{NO}_{2}+\mathrm{NO}_{3}\right.$ in table 6$)$ in water samples from this aquifer system generally were at or below detection levels at the eight study basins. Concentrations of ammonia and organic nitrogen were greater in water samples from wells in the reclaimed basins than in water samples from wells in the unmined basins. Concentrations of ammonia ranged from 0.06 to $0.1 \mathrm{mg} / \mathrm{L}$ at the unmined basins and from 0.69 to $17.4 \mathrm{mg} / \mathrm{L}$ at the reclaimed basins. Concentrations of organic nitrogen were 0.15 and $0.25 \mathrm{mg} / \mathrm{L}$ at two unmined basins and ranged from 0.41 to $2.0 \mathrm{mg} / \mathrm{L}$ at the reclaimed basins.

Total phosphorus concentrations in water from the surficial aquifer system ranged from 0.27 to $6.1 \mathrm{mg} / \mathrm{L}$ at seven of the eight study basins; however, the concentration at the Agrico-1 Creek basin was significantly higher at
$49.0 \mathrm{mg} / \mathrm{L}$. Concentrations of orthophosphorus ranged from below the detection limit of $0.01 \mathrm{mg} / \mathrm{L}$ to $5.4 \mathrm{mg} / \mathrm{L}$ at the unmined basins and from below the detection limit to $3.1 \mathrm{mg} / \mathrm{L}$ at the reclaimed basins (fig. 59 and table 7 ).

\section{Major Constituents}

Major constituents, as discussed in this section, include those cations and anions that constitute the bulk of the dissolved solids and include those constituents that commonly occur in concentrations exceeding $1.0 \mathrm{mg} / \mathrm{L}$. The major dissolved cations generally are calcium, magnesium, sodium, and potassium; the major anions are sulfate, chloride, fluoride, nitrate, and constituents contributing to alkalinity, primarily bicarbonate and carbonate (Hem, 1989). The $\mathrm{pH}$ of ground water also is discussed in this section. At the eight study basins, $\mathrm{pH}$ values for water samples from the surficial aquifer system ranged from 4.9 to 7.3 standard units (table 7 ).

NOVEMBER $22-24,1988$
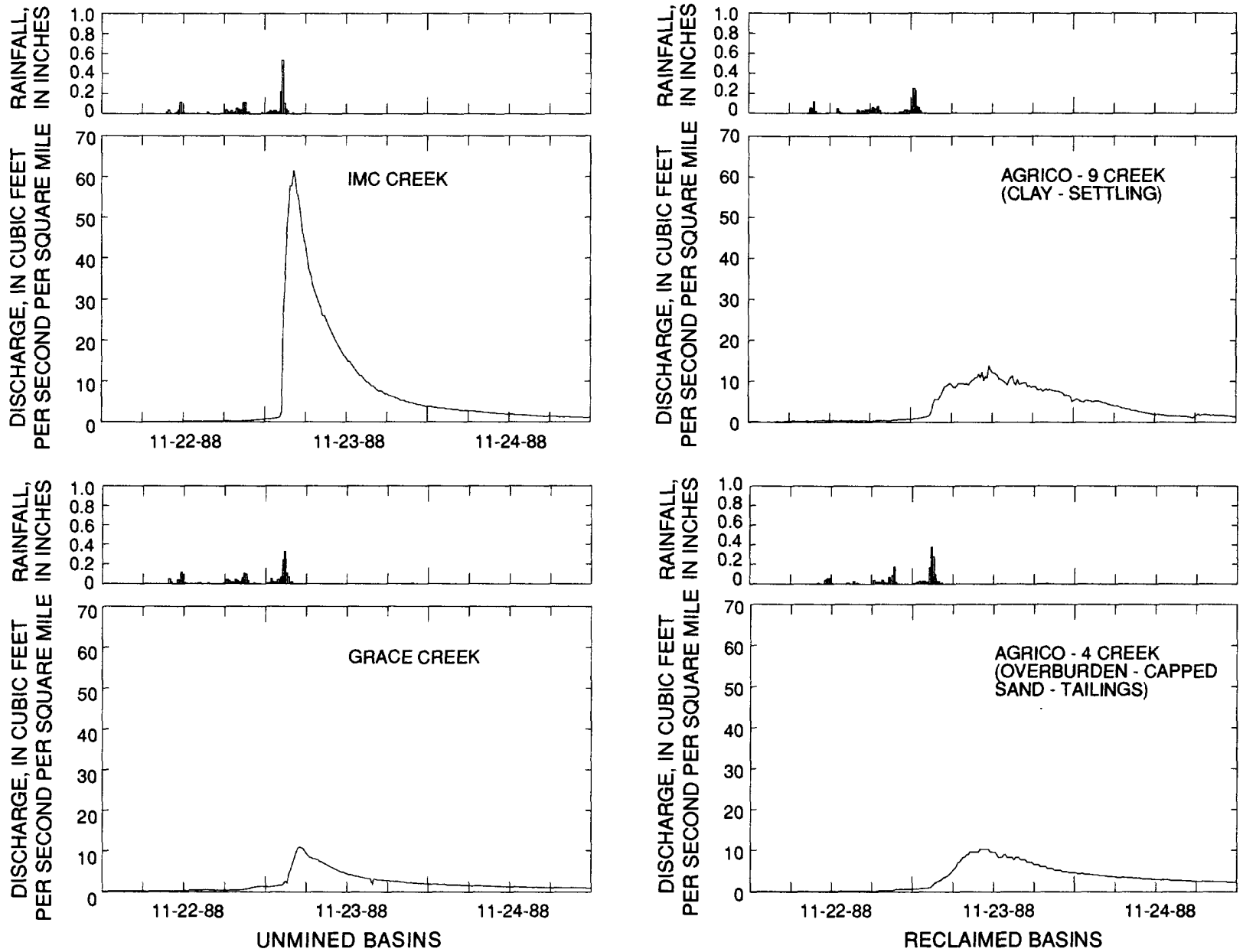

Figure 58.(Continued) Discharge and rainfall during typical frontal storms, 1988-90. 
The $\mathrm{pH}$ values for many of the samples were below the minimum value of 6.5 recommended by the FDER in its secondary drinking water standards (Florida Department of Environmental Regulation, 1992).

Alkalinity in water samples from wells completed in the surficial aquifer system ranged from below the detection limit of 0.1 to $39 \mathrm{mg} / \mathrm{L}$ at the three unmined basins and from 11 to $352 \mathrm{mg} / \mathrm{L}$ at the five reclaimed basins (table 7). The high alkalinity of water from this aquifer system at CFI-1 Creek and Agrico-4 Creek basins may be attributed to water from the Upper Floridan aquifer that was used to transport tailings back to the mined site during reclamation. Alkalinity levels at Agrico-9 Creek and Agrico-1 Creek reclaimed basins were similar to those observed in ground water at the unmined basins. The low levels of alkalinity at these two basins and at the unmined basins indicate that rainfall is recharging the surficial aquifer system and that the residence time of the water in the aquifer is short (R.L. Miller, U.S. Geological Survey, oral commun., 1991).
Concentrations of calcium in ground-water samples collected at the unmined basins ranged from 2.0 to $11 \mathrm{mg} / \mathrm{L}$, and concentrations in samples collected at the reclaimed basins ranged from $6.8 \mathrm{mg} / \mathrm{L}$ at Agrico-9 Creek basin to $100 \mathrm{mg} / \mathrm{L}$ at Mobil Creek basin (table 6). Extreme values for calcium concentrations, both low and high, were observed in ground-water samples from the reclaimed basins.

Chloride concentrations in water samples from the surficial aquifer system were similar among the eight basins. Concentrations ranged from 1.6 to $31 \mathrm{mg} / \mathrm{L}$ (table 7), well below the FDER secondary drinking water standard of $250 \mathrm{mg} / \mathrm{L}$.

With the exception of the Mobil Creek basin, sulfate concentrations in water from the surficial aquifer system were relatively low. Concentrations of sulfate ranged from 6.5 to $37 \mathrm{mg} / \mathrm{L}$ in ground-water samples from the unmined basins and from 0.04 to $10 \mathrm{mg} / \mathrm{L}$ in samples from the reclaimed basins (excluding the Mobil Creek basin). In the Mobil Creek basin, sulfate concentrations ranged from 120 to $320 \mathrm{mg} / \mathrm{L}$, exceeding the FDER secondary drinking water standard of $250 \mathrm{mg} / \mathrm{L}$.

JANUARY $21-24,1989$
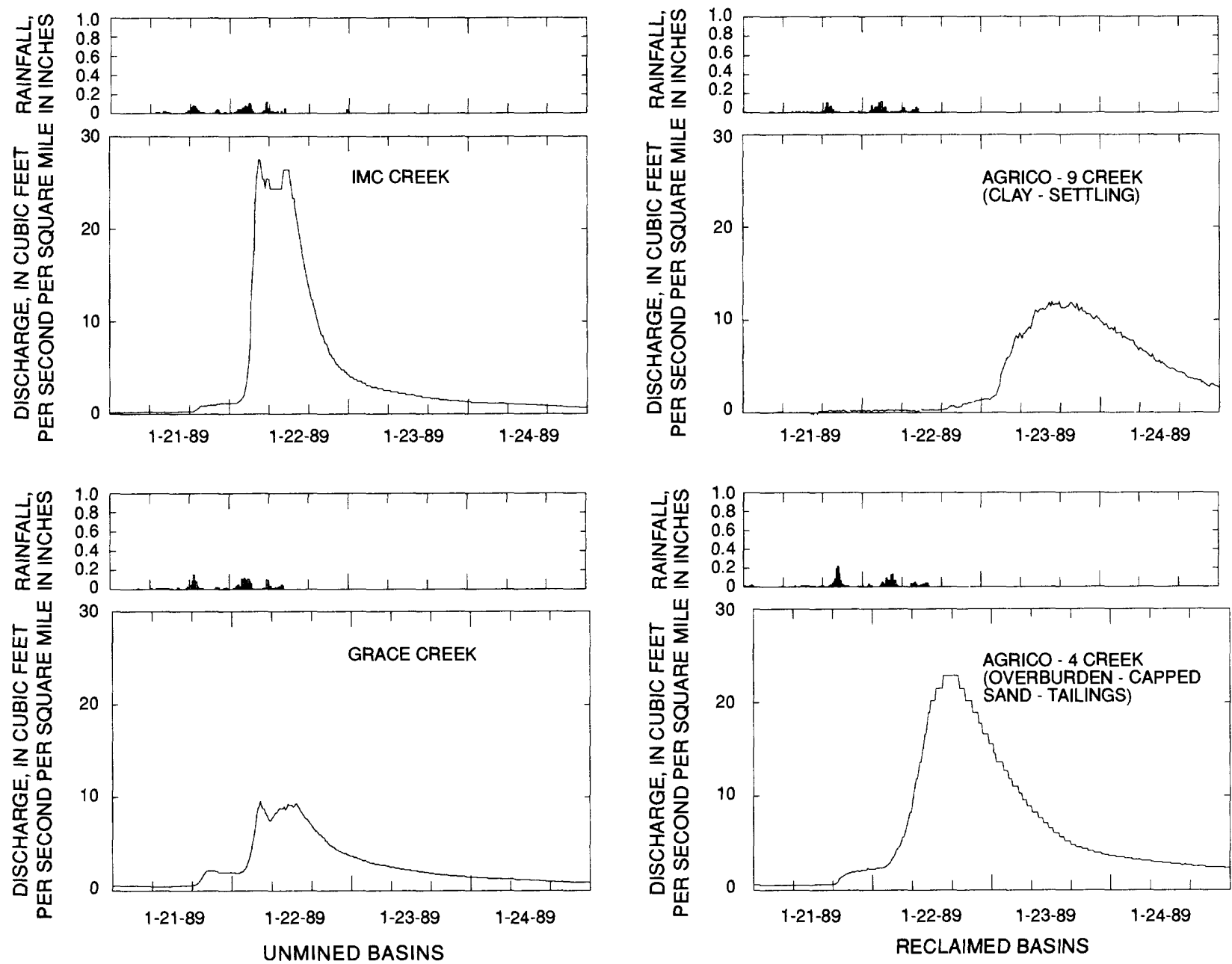

Figure 58.(Continued) Discharge and rainfall during typical frontal storms, 1988-90. 
MARCH $1-4,1989$
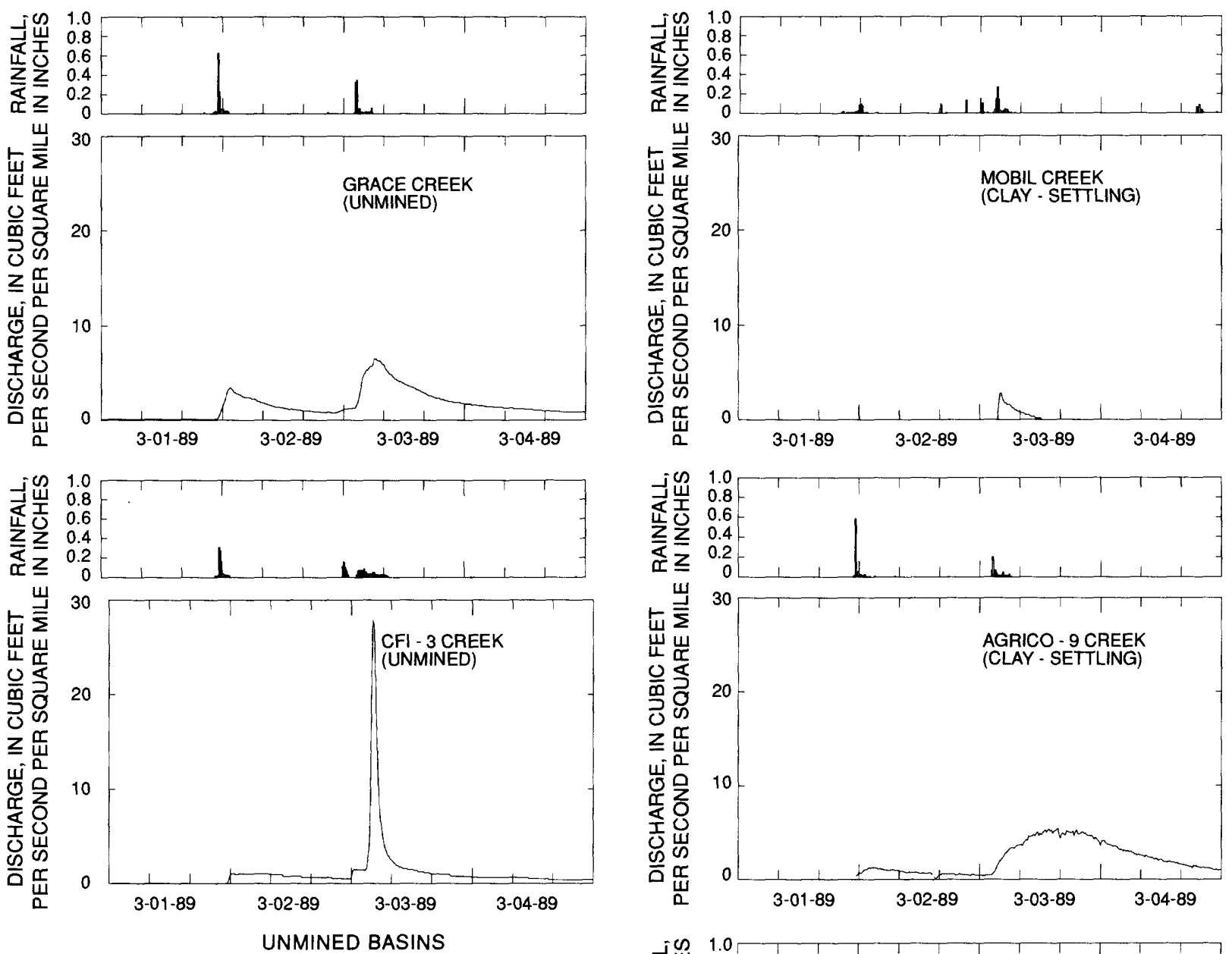

Figure 58.(Continued) Discharge and rainfall during typical frontal storms, 1988-90.

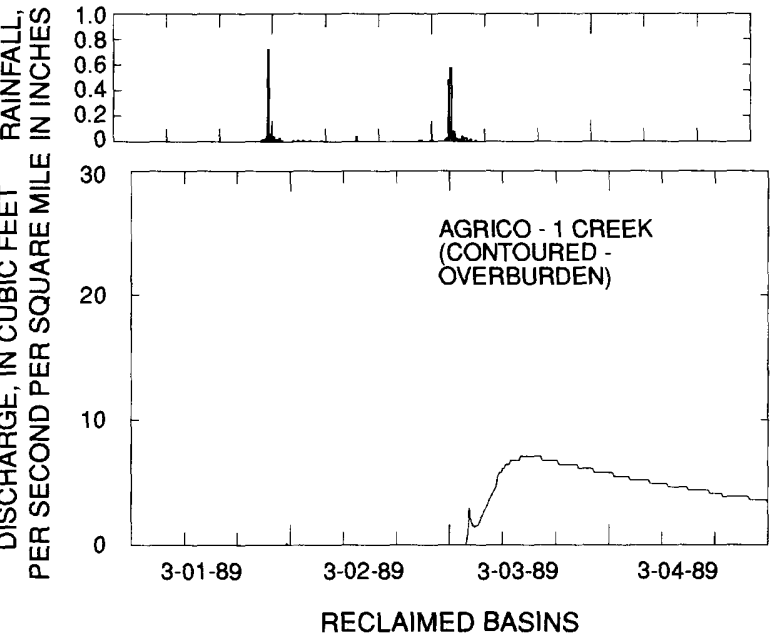



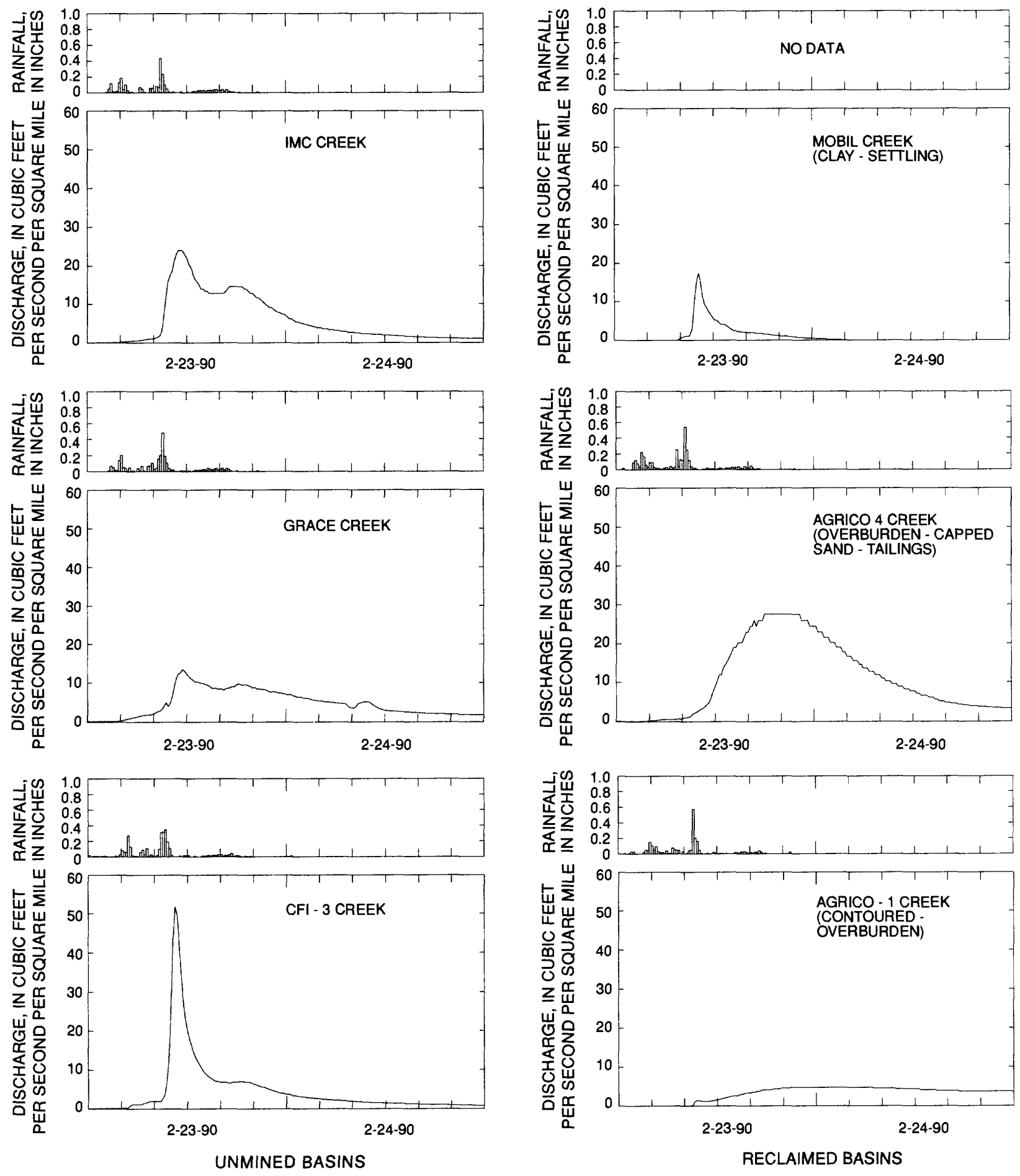

Figure 58.(Continued) Discharge and rainfall during typical frontal storms, 1988-90. 
Table 5. Peak discharge, rainfall, and runoff during typical frontal storms in the west-central Florida phosphate-mining region, 1988-90

$\left[\left(\left[\mathrm{ft}^{3} / \mathrm{s}\right) / \mathrm{mi}^{2}\right.\right.$, cubic feet per second per square mile; --, no data]

\begin{tabular}{|c|c|c|c|c|c|c|c|c|c|}
\hline \multirow[b]{2}{*}{ Basin } & \multirow{2}{*}{$\begin{array}{c}\text { Peak } \\
\text { discharge } \\
{\left[\left(\mathrm{ft}^{3} / \mathrm{s}\right) / \mathrm{mi}^{2}\right]}\end{array}$} & \multirow{2}{*}{$\begin{array}{l}\text { Rainfall } \\
\text { (inches) }\end{array}$} & \multirow{2}{*}{$\begin{array}{l}\text { Storm } \\
\text { runoff' } \\
\text { (inches) }\end{array}$} & \multirow{2}{*}{$\begin{array}{c}\text { Runoff } \\
\text { coefficient }^{2} \\
\text { (percent) }\end{array}$} & \multirow{2}{*}{$\begin{array}{l}\text { Time } \\
\text { from } \\
\text { rise } \\
\text { to peak } \\
\text { (hours) }\end{array}$} & \multicolumn{2}{|c|}{$\begin{array}{l}\text { Maximum rainfall } \\
\text { intensity for } \\
\text { indicated periods } \\
\text { (inches) }\end{array}$} & \multicolumn{2}{|c|}{$\begin{array}{c}\text { Rainfall during } \\
\text { indicated number of } \\
\text { days previous to storm } \\
\text { (inches) }\end{array}$} \\
\hline & & & & & & 15 minutes & 1 hour & 3 days & 7 days \\
\hline \multicolumn{10}{|c|}{ November 3-6, 1988} \\
\hline $\begin{array}{l}\text { Grace Creek } \\
\text { (unmined) }\end{array}$ & 9.16 & 2.72 & 0.09 & 3.31 & 3.75 & 0.45 & 0.89 & 0.00 & 0.00 \\
\hline $\begin{array}{l}\text { Agrico-9 Creek } \\
\text { (clay-settling) }\end{array}$ & 3.58 & 2.41 & .28 & 11.6 & 19.40 & .52 & .60 & .00 & .00 \\
\hline $\begin{array}{l}\text { Agrico-1 Creek } \\
\text { (contoured- } \\
\text { overburden) }\end{array}$ & 8.63 & 2.94 & .77 & 26.2 & 5.00 & .41 & .81 & .00 & .00 \\
\hline \multicolumn{10}{|c|}{ November 22-24, 1988} \\
\hline $\begin{array}{r}\text { IMC Creek) } \\
\text { (unmined }\end{array}$ & 61.0 & 2.08 & .76 & 36.54 & 7.50 & .56 & .95 & .00 & .00 \\
\hline $\begin{array}{l}\text { Grace Creek } \\
\text { (unmined) }\end{array}$ & 11.0 & 1.91 & .16 & 8.38 & 4.00 & .34 & .79 & .00 & .00 \\
\hline $\begin{array}{l}\text { Agrico-9 Creek } \\
\text { (clay-settling) }\end{array}$ & 13.8 & 1.82 & .46 & 25.3 & 26.25 & .29 & .64 & .04 & .04 \\
\hline $\begin{array}{l}\text { Agrico-4 Creek } \\
\text { (overburden-capped } \\
\text { sand-tailings) }\end{array}$ & 10.3 & 2.08 & .46 & 22.1 & 11.00 & .39 & .95 & .00 & .00 \\
\hline \multicolumn{10}{|c|}{ January 21-24, 1989} \\
\hline $\begin{array}{l}\text { IMC Creek } \\
\text { (unmined) }\end{array}$ & 27.1 & 2.44 & .66 & 27.05 & 4.50 & .11 & .35 & .00 & .09 \\
\hline $\begin{array}{r}\text { Grace Creek } \\
\text { (unmined) }\end{array}$ & 9.58 & 2.89 & .41 & 14.2 & 4.00 & .34 & .50 & .00 & .07 \\
\hline $\begin{array}{l}\text { Agrico-9 Creek } \\
\text { (clay-settling) }\end{array}$ & 12.0 & 2.49 & .60 & 24.1 & 48.75 & .30 & .56 & .00 & .00 \\
\hline Agrico-4 Creek & 22.9 & 2.56 & .77 & 30.1 & 22.00 & .26 & .67 & .50 & .59 \\
\hline \multicolumn{10}{|c|}{ March 1-4, 1989} \\
\hline $\begin{array}{r}\text { Grace Creek } \\
\text { (unmined) }\end{array}$ & 6.48 & .95 & .11 & 11.6 & 4.00 & .36 & .74 & 1.20 & 1.20 \\
\hline $\begin{array}{l}\text { CFI-3 Creek } \\
\text { (unmined) }\end{array}$ & 27.8 & 1.79 & .11 & 6.14 & 4.50 & .16 & .45 & .74 & .74 \\
\hline $\begin{array}{l}\text { Mobil Creek } \\
\quad \text { (clay-settling) }\end{array}$ & 2.72 & 1.56 & .01 & .64 & .50 & .28 & .63 & .24 & .24 \\
\hline $\begin{array}{l}\text { Agrico-9 Creek } \\
\text { (clay-settling) }\end{array}$ & 5.38 & 1.90 & .28 & 14.7 & 13.00 & .74 & .89 & .00 & .00 \\
\hline Agrico-1 Creek & 7.26 & 1.56 & .51 & 32.7 & 8.25 & .60 & 1.26 & 1.18 & 1.18 \\
\hline \multicolumn{10}{|c|}{ February 23-24, 1990} \\
\hline $\begin{array}{l}\text { IMC Creek } \\
\quad \text { (unmined) }\end{array}$ & 23.6 & 2.58 & .42 & 16.28 & 8.25 & .45 & .86 & .04 & .04 \\
\hline $\begin{array}{r}\text { Grace Creek } \\
\text { (unmined) }\end{array}$ & 13.5 & 2.93 & .34 & 11.6 & 8.00 & .50 & 1.07 & .30 & .30 \\
\hline $\begin{array}{r}\text { CFI-3 Creek } \\
\text { (unmined) }\end{array}$ & 51.8 & 3.10 & .32 & 10.3 & 6.75 & .36 & 1.21 & .02 & .18 \\
\hline $\begin{array}{l}\text { Mobil Creek } \\
\quad \text { (clay-settling) }\end{array}$ & 17.2 & 2.41 & .08 & 3.21 & 2.50 & .75 & .81 & .24 & .34 \\
\hline $\begin{array}{l}\text { Agrico-4 Creek } \\
\text { (overburden-capped } \\
\text { sand-tailings) }\end{array}$ & 27.5 & 3.32 & .89 & 26.8 & 15.25 & .56 & 1.07 & .20 & .20 \\
\hline $\begin{array}{l}\text { Agrico-1 Creek } \\
\text { (contoured- } \\
\text { overburden) }\end{array}$ & 4.99 & 2.61 & .45 & 17.4 & 16.50 & .60 & 1.03 & .00 & .00 \\
\hline
\end{tabular}

'Storm runoff is computed as the total runoff minus the base flow, in inches.

${ }^{2}$ Runoff coefficient is storm runoff volume divided by rainfall volume multiplied by 100 percent. 
Table 6. Physical and chemical characteristics of water from the surficial aquifer system at the eight study basins-reconnaissance samples

$\left[{ }^{\circ} \mathrm{C}\right.$, degrees Celsius; NTU, nephelometric turbidity units; Pt-Co, platinum-cobalt; $\mathrm{mg} / \mathrm{L}$, milligrams per liter; $\mu \mathrm{g} / \mathrm{L}, \mathrm{micrograms}$ per liter; <, less than; -- , not sampled]

\begin{tabular}{|c|c|c|c|c|c|c|c|c|}
\hline \multirow[b]{2}{*}{ Property or constituent } & \multicolumn{3}{|c|}{ Unmined basins } & \multicolumn{5}{|c|}{ Reclaimed basins } \\
\hline & $\begin{array}{c}\text { IMC } \\
\text { Creek } \\
\text { well 1 } \\
11-22-88\end{array}$ & $\begin{array}{c}\text { Grace } \\
\text { Creek } \\
\text { well } 4 \\
11-22-88\end{array}$ & $\begin{array}{c}\text { CFI-3 } \\
\text { Creek } \\
\text { well 1 } \\
11-29-88\end{array}$ & $\begin{array}{c}\text { Mobil } \\
\text { Creek } \\
\text { well } 8 \\
11-28-88\end{array}$ & $\begin{array}{c}\text { Agrico-9 } \\
\text { Creek } \\
\text { well } 12 \\
11-30-88\end{array}$ & $\begin{array}{c}\text { CFI-1 } \\
\text { Creek } \\
\text { well 1 } \\
11-30-88\end{array}$ & $\begin{array}{c}\text { Agrico-4 } \\
\text { Creek } \\
\text { well } 9 \\
11-16-88\end{array}$ & $\begin{array}{c}\text { Agrico-1 } \\
\text { Creek } \\
\text { well 11 } \\
11-18-88\end{array}$ \\
\hline Temperature, $\left({ }^{\circ} \mathrm{C}\right)$ & 24.5 & 24.5 & 20.0 & 24.0 & 24.0 & 24.5 & 23.5 & 26.0 \\
\hline Turbidity (NTU) & 2.3 & 58 & -- & -- & -- & -- & 7.0 & 540 \\
\hline Color (Pt-Co units) & 5 & -- & 7 & 35 & $<5$ & 5 & 10 & -- \\
\hline Nitrogen, organic, total $(\mathrm{mg} / \mathrm{L}$ as $\mathrm{N})$ & -- & .15 & .25 & 1.1 & .41 & 1.5 & 1.6 & 2.0 \\
\hline Nitrogen, ammonia, total (mg/L as $\mathrm{N})$ & .06 & .10 & .06 & 1.40 & .69 & 7.0 & 17.4 & 3.0 \\
\hline $\begin{array}{l}\text { Nitrogen, ammonia + organic, total } \\
(\mathrm{mg} / \mathrm{L} \text { as } \mathrm{N})\end{array}$ & $<.20$ & .25 & .31 & 2.5 & 1.1 & 8.5 & 19 & 5.0 \\
\hline Nitrogen, $\mathrm{NO}_{2}+\mathrm{NO}_{3}$, total $(\mathrm{mg} / \mathrm{L}$ as $\mathrm{N})$ & .03 & .02 & $<.02$ & $<.02$ & $<.02$ & $<.02$ & $<.02$ & .05 \\
\hline $\begin{array}{l}\text { Nitrogen, } \mathrm{NO}_{2}+\mathrm{NO}_{3} \text {, dissolved } \\
\quad(\mathrm{mg} / \mathrm{L} \text { as } \mathrm{N})\end{array}$ & .03 & .02 & .03 & $<.02$ & .02 & $<.02$ & $<.02$ & $<.02$ \\
\hline Phosphorus, total (mg/L as $\mathrm{P}$ ) & .27 & 4.5 & 4.2 & 6.1 & 1.1 & 1.0 & .40 & 49 \\
\hline Hardness, total $\left(\mathrm{mg} / \mathrm{L}\right.$ as $\left.\mathrm{CaCO}_{3}\right)$ & 12 & 48 & 11 & 44 & 33 & 290 & 22 & 3 \\
\hline Calcium, dissolved (mg/L as $\mathrm{Ca})$ & 2.0 & 11 & 2.2 & 100 & 6.8 & 64 & 34 & 8.4 \\
\hline Magnesium, dissolved ( $\mathrm{mg} / \mathrm{L}$ as $\mathrm{Mg}$ ) & 1.8 & 5.1 & 1.3 & 46 & 3.8 & 32 & 32 & 3.1 \\
\hline Sodium, dissolved ( $\mathrm{mg} / \mathrm{L}$ as $\mathrm{Na}$ ) & 3.8 & 11 & 7.9 & 18 & 10 & 7.1 & 11 & 14 \\
\hline Potassium, dissolved (mg/L as $\mathrm{K})$ & 3.8 & .20 & .10 & 1.5 & .20 & 1.2 & 2.0 & .50 \\
\hline Fluoride, dissolved (mg/L as F) & $<.10$ & .70 & .20 & 1.1 & .40 & 1.6 & 1.5 & .50 \\
\hline Iodide, dissolved (mg/L as I) & -- & .022 & .023 & .016 & .053 & -. & .015 & .027 \\
\hline Silica, dissolved $\left(\mathrm{mg} / \mathrm{L}\right.$ as $\left.\mathrm{SiO}_{2}\right)$ & 1.3 & 11 & 5.3 & 41 & 6.7 & 8.0 & 14 & 22 \\
\hline Arsenic, total $(\mu \mathrm{g} / \mathrm{L}$ as As $)$ & $<1$ & 1 & 1 & 3 & 7 & 2 & $<1$ & 2 \\
\hline Barium, dissolved ( $\mu \mathrm{g} / \mathrm{L}$ as $\mathrm{Ba})$ & 13 & $<2$ & 10 & 18 & $<2$ & 6 & 9 & 2 \\
\hline $\begin{array}{l}\text { Beryllium, total recoverable } \\
\qquad(\mu \mathrm{g} / \mathrm{L} \text { as } \mathrm{Be})\end{array}$ & $<10$ & $<10$ & $<10$ & $<10$ & $<10$ & $<10$ & $<10$ & 10 \\
\hline Boron, total recoverable $(\mu \mathrm{g} / \mathrm{L}$ as B $)$ & $<10$ & 30 & 30 & 50 & 30 & 40 & 70 & 80 \\
\hline Cadmium, total $(\mu \mathrm{g} / \mathrm{L}$ as $\mathrm{Cd})$ & $<1$ & 1 & 1 & $<1$ & 1 & $<1$ & 1 & $<1$ \\
\hline Cobalt, dissolved $(\mu \mathrm{g} / \mathrm{L}$ as $\mathrm{Co})$ & $<3$ & $<3$ & $<3$ & $<3$ & 10 & 6 & $<3$ & $<3$ \\
\hline Copper, dissolved $(\mu \mathrm{g} / \mathrm{L}$ as $\mathrm{Cu})$ & $<10$ & $<10$ & $<10$ & $<10$ & $<10$ & $<10$ & $<10$ & $<10$ \\
\hline Iron, total $(\mu \mathrm{g} / \mathrm{L}$ as Fe $)$ & .27 & .91 & 3.3 & 12 & 11 & 10 & 2.6 & 11 \\
\hline Lead, total $(\mu \mathrm{g} / \mathrm{L}$ as $\mathrm{Pb})$ & $<10$ & 7 & $<5$ & $<5$ & $<5$ & $<5$ & $<5$ & 96 \\
\hline Lithium, dissolved ( $\mu \mathrm{g} / \mathrm{L}$ as $\mathrm{Li})$ & $<4$ & $<4$ & $<4$ & 10 & $<4$ & 7 & $<4$ & $<4$ \\
\hline Manganese, dissolved $(\mu \mathrm{g} / \mathrm{L}$ as $\mathrm{Mn})$ & 8 & 2 & 19 & 150 & 42 & 140 & 49 & 18 \\
\hline Mercury, dissolved $(\mu \mathrm{g} / \mathrm{L}$ as $\mathrm{Hg})$ & $<.1$ & $<.1$ & $<.1$ & .1 & $<.1$ & .2 & $<.1$ & $<.1$ \\
\hline Molybdenum, dissolved ( $\mu \mathrm{g} / \mathrm{L}$ as $\mathrm{Mo}$ ) & $<10$ & $<10$ & $<10$ & $<10$ & $<10$ & $<10$ & $<10$ & $<10$ \\
\hline Nickel, dissolved ( $\mu \mathrm{g} / \mathrm{L}$ as $\mathrm{Ni})$ & $<10$ & $<10$ & $<10$ & $<10$ & $<10$ & $<10$ & $<10$ & 10 \\
\hline Silver, dissolved $(\mu \mathrm{g} / \mathrm{L}$ as $\mathrm{Ag})$ & 1.0 & 3.0 & $<1.0$ & $<1.0$ & $<1.0$ & $<1.0$ & $<1.0$ & $<1.0$ \\
\hline Strontium, dissolved ( $\mu \mathrm{g} / \mathrm{L}$ as $\mathrm{Sr})$ & 10 & 10 & 50 & 190 & 60 & 100 & 100 & 30 \\
\hline Vanadium, dissolved ( $\mu \mathrm{g} / \mathrm{L}$ as $\mathrm{V})$ & $<6$ & $<6$ & $<6$ & $<6$ & $<6$ & $<6$ & $<6$ & 12 \\
\hline Zinc, total $(\mu \mathrm{g} / \mathrm{L}$ as $\mathrm{Zn})$ & $<10$ & 20 & 10 & $<10$ & 10 & $<10$ & $<10$ & 50 \\
\hline Gross alpha, dissolved ( $\mathrm{pCi} / \mathrm{L}$ as U-nat) & 4.0 & 53 & 37 & 4.3 & 1.9 & 3.2 & 3.88 & 5.24 \\
\hline Gross beta, dissolved (pCi/L as Cs-137) & 5.5 & 10 & 5.0 & 4.0 & .8 & 2.3 & 3.5 & 5.4 \\
\hline Gross beta, dissolved ( $\mathrm{PCi} / \mathrm{L}$ as $\mathrm{Sr} / \mathrm{Yt})$ & 5.2 & 8.1 & 4.6 & 2.8 & .6 & 1.8 & 2.7 & 4.2 \\
\hline $\begin{array}{l}\text { Radium 226, dissolved (radon method, } \\
\text { pCi/L) }\end{array}$ & .64 & .76 & .91 & .89 & .27 & 1.4 & 1.4 & 2.1 \\
\hline Polonium 210, dissolved ( $\mathrm{pCi} / \mathrm{L})$ & -- & -- & -- & -- & -- & $-\infty$ & $<1.0$ & $<1.0$ \\
\hline Uranium-238, water dissolved (pCi/L) & $<.1$ & $<.10$ & $<.10$ & $\cdot .30$ & $<.10$ & $<.10$ & $<.10$ & .60 \\
\hline Uranium-234, water dissolved (pCi/L) & $<.10$ & .10 & $<.10$ & .30 & $<.10$ & $<.10$ & $<.10$ & .70 \\
\hline $\begin{array}{l}\text { Solids, sum of constituents, } \\
\text { dissolved }(\mathrm{mg} / \mathrm{L})\end{array}$ & 32 & 98 & -- & 623 & 88 & 294 & 284 & 105 \\
\hline
\end{tabular}


Table 7. Physical and chemical characteristics of water from the surficial aquifer system at the eight study basins--bimonthly samples

$\left[{ }^{\circ} \mathrm{C}\right.$, degrees Celsius; $\mu \mathrm{S} / \mathrm{cm}$, microsiemens per centimeter at $25^{\circ} \mathrm{C} ; \mathrm{mg} / \mathrm{L}$, milligrams per liter; --, not sampled; <, less than]

\begin{tabular}{|c|c|c|c|c|c|c|c|c|}
\hline Date & $\begin{array}{c}\text { Water } \\
\text { temperature } \\
\left({ }^{\circ} \mathrm{C}\right)\end{array}$ & $\begin{array}{c}\text { Specific } \\
\text { conductance } \\
(\mu \mathrm{S} / \mathrm{cm})\end{array}$ & $\begin{array}{c}\mathrm{pH} \\
\text { (standard } \\
\text { units) }\end{array}$ & $\begin{array}{c}\text { Ortho- } \\
\text { phosphorus } \\
\text { (mg/L as } \mathrm{P} \text { ) }\end{array}$ & $\begin{array}{c}\text { Chloride } \\
(\mathrm{mg} / \mathrm{L} \\
\text { as P) }\end{array}$ & $\begin{array}{c}\text { Sulfate } \\
(\mathrm{mg} / \mathrm{L} \\
\left.\text { as } \mathrm{SO}_{4}\right)\end{array}$ & $\begin{array}{c}\text { Alkalinity } \\
(\mathrm{mg} / \mathrm{L} \\
\left.\text { as } \mathrm{CaCO}_{3}\right)\end{array}$ & $\begin{array}{c}\text { Dissolved } \\
\text { solids } \\
(\mathrm{mg} / \mathrm{L})\end{array}$ \\
\hline \multicolumn{9}{|c|}{ IMC Creek basin (unmined) surficial aquifer system well 1} \\
\hline $11-22-88$ & 24.5 & 75 & -- & $<0.01$ & 8.0 & 7.6 & 5.6 & 34 \\
\hline $4-10-89$ & 25.0 & 74 & 6.2 & .01 & 8.6 & 7.3 & 4.8 & 48 \\
\hline $5-08-89$ & 25.0 & 48 & -- & .02 & 8.1 & 7.1 & 4.4 & 31 \\
\hline $6-12-89$ & 26.5 & 70 & 5.2 & .01 & 8.1 & 7.4 & 4.4 & 29 \\
\hline $7-11-89$ & 28.5 & 75 & 5.3 & .21 & 8.2 & 7.3 & 4.1 & 35 \\
\hline $8-08-89$ & 29.5 & 74 & 5.4 & .01 & 11 & 7.8 & 3.6 & 45 \\
\hline $9-05-89$ & 28.0 & 77 & 5.4 & .02 & 11 & 7.6 & -- & 30 \\
\hline $10-10-89$ & 26.0 & 65 & 5.5 & .02 & 9.2 & 7.4 & -- & 42 \\
\hline $12-04-89$ & 20.0 & 74 & 5.6 & .01 & 9.0 & 7.8 & 4.8 & 35 \\
\hline $1-17-90$ & 23.5 & -- & 5.8 & .01 & 8.5 & 7.5 & 3.0 & 33 \\
\hline $2-27-90$ & 23.0 & 73 & 5.9 & .01 & 8.6 & 7.4 & 3.6 & 34 \\
\hline $4-10-90$ & 24.0 & 61 & 5.6 & $<.01$ & 8.6 & 7.5 & 4.4 & 31 \\
\hline $5-21-90$ & 25.5 & 68 & 5.6 & .01 & 8.2 & 7.7 & 4.8 & 26 \\
\hline $6-29-90$ & 27.5 & 72 & 5.6 & .01 & 8.0 & 7.6 & 4.6 & 24 \\
\hline 8-07-90 & 27.5 & 74 & 5.6 & .01 & 8.1 & 8.2 & 4.3 & 35 \\
\hline $10-02-90$ & 30.0 & 75 & 5.6 & .01 & 7.7 & 7.8 & 4.1 & 28 \\
\hline \multicolumn{9}{|c|}{ Grace Creek basin (unmined) surficial aquifer system well 4} \\
\hline $11-22-88$ & 24.5 & 217 & -- & .34 & 31 & 9.1 & 12 & 107 \\
\hline $4-10-89$ & 27.5 & 196 & -- & 2.7 & 11 & 37 & 12 & 117 \\
\hline $5-08-89$ & 24.0 & 193 & -. & 1.6 & 10 & 35 & 12 & 99 \\
\hline $6-13-89$ & 28.0 & 178 & 5.7 & 1.8 & 10 & 36 & 12 & 100 \\
\hline $7-12-89$ & 27.0 & 212 & 6.2 & .07 & 26 & 17 & 23 & 127 \\
\hline $8-07-89$ & 30.5 & 240 & 6.0 & -- & 23 & 16 & 23 & 127 \\
\hline $9-08-89$ & 27.0 & 207 & 5.9 & .81 & 26 & 16 & 30 & 136 \\
\hline $10-11-89$ & 28.5 & 199 & 6.0 & 1.4 & 25 & 16 & 24 & 134 \\
\hline $11-30-89$ & 25.0 & 209 & 6.4 & .55 & 24 & 15 & 23 & 127 \\
\hline $1-18-90$ & 25.0 & 180 & 5.9 & .68 & 22 & 16 & 17 & 110 \\
\hline $2-28-90$ & 22.5 & -- & 5.8 & .65 & 23 & 17 & 21 & 108 \\
\hline $4-11-90$ & 25.5 & 212 & 5.9 & .75 & 23 & 16 & 27 & 118 \\
\hline $5-22-90$ & 25.0 & 208 & 6.1 & .41 & 22 & 15 & 39 & 122 \\
\hline $7-02-90$ & 26.5 & 186 & 5.9 & 2.1 & 20 & 15 & 12 & 113 \\
\hline $8-08-90$ & 30.0 & 142 & 5.4 & 5.4 & 16 & 6.6 & 18 & 178 \\
\hline $10-03-90$ & 30.5 & 150 & 5.9 & 2.1 & 21 & 12 & 23 & 109 \\
\hline
\end{tabular}

CFI-3 Creek basin (unmined) surficial aquifer system well 1

$\begin{array}{rcrccccrr}11-29-88 & 23.0 & 101 & -- & .18 & 18 & 6.5 & <.1 & 69 \\ 4-07-89 & 23.0 & 85 & 5.3 & .59 & 14 & 8.5 & .5 & 60 \\ 5-11-89 & 25.5 & 78 & 5.2 & .41 & 11 & 9.0 & 2.1 & 41 \\ 6-09-89 & 30.0 & 80 & 5.6 & .41 & 10 & 9.7 & 1.6 & 40 \\ 7-18-89 & -- & -- & -- & .49 & 11 & 11 & 5.4 & 52 \\ 8-11-89 & 31.0 & 85 & 5.4 & .72 & 7.1 & 12 & 6.9 & 49 \\ 9-06-89 & 30.5 & 93 & 5.4 & .71 & 6.5 & 13 & 4.1 & 56 \\ 10-20-89 & 24.0 & 77 & 5.4 & .71 & 7.4 & 16 & 4.9 & 46 \\ 12-07-90 & 23.5 & 80 & 5.2 & .25 & 11 & 13 & 2.3 & 64 \\ 1-25-90 & 24.5 & 82 & 5.0 & .19 & 11 & 13 & <.1 & 57 \\ 3-08-90 & 21.5 & 85 & 5.2 & .14 & 9.6 & 14 & .8 & 51 \\ 4-19-90 & 22.5 & 97 & 5.4 & 1.2 & 8.3 & 14 & 2.1 & 50 \\ 5-29-90 & 26.0 & 95 & 5.2 & .56 & 8.9 & 13 & 1.6 & 49 \\ 7-05-90 & 27.5 & -- & 5.4 & .68 & 5.8 & 14 & 5.2 & 47 \\ 8-16-90 & 28.5 & 98 & 5.5 & .47 & 9.0 & 13 & .5 & 36 \\ 10-10-90 & 27.5 & 95 & 5.4 & .50 & 9.2 & 15 & .6 & 47\end{array}$


Table 7. Physical and chemical characteristics of water from the surficial aquifer system at the eight study basins--bimonthly samples--Continued

\begin{tabular}{|c|c|c|c|c|c|c|c|c|}
\hline Date & $\begin{array}{c}\text { Water } \\
\text { temperature } \\
\left({ }^{\circ} \mathrm{C}\right)\end{array}$ & $\begin{array}{c}\text { Specific } \\
\text { conductance } \\
(\mu \mathrm{S} / \mathrm{cm})\end{array}$ & $\begin{array}{c}\mathrm{pH} \\
\text { (standard } \\
\text { units) }\end{array}$ & $\begin{array}{c}\text { Ortho- } \\
\text { phosphorus } \\
\text { (mg/L as } \mathrm{P})\end{array}$ & $\begin{array}{c}\text { Chloride } \\
\text { (mg/L } \\
\text { as P) }\end{array}$ & $\begin{array}{c}\text { Sulfate } \\
(\mathrm{mg} / \mathrm{L} \\
\left.\text { as } \mathrm{SO}_{4}\right)\end{array}$ & $\begin{array}{l}\text { Alkalinity } \\
(\mathrm{mg} / \mathrm{L} \\
\left.\text { as } \mathrm{CaCO}_{3}\right)\end{array}$ & $\begin{array}{l}\text { Dissolved } \\
\text { solids } \\
(\mathrm{mg} / \mathrm{L})\end{array}$ \\
\hline \multicolumn{9}{|c|}{ Mobil Creek basin (clay-settling) surficial aquifer system well 8} \\
\hline $11-28-88$ & 24.0 & 905 & 5.9 & .27 & 8.4 & 320 & 120 & 686 \\
\hline $4-06-89$ & 22.5 & 773 & 6.0 & .55 & 6.4 & 250 & 110 & 561 \\
\hline $6-13-89$ & 30.5 & 705 & 7.0 & .51 & 7.2 & 250 & 114 & 539 \\
\hline $7-17-89$ & -- & -- & -- & .22 & 8.5 & 220 & 102 & 522 \\
\hline $8-09-89$ & 29.0 & 630 & 5.8 & .32 & 6.9 & 230 & 102 & 521 \\
\hline 9-06-89 & 27.5 & 622 & 5.8 & .30 & 7.0 & 230 & 101 & 504 \\
\hline $10-20-89$ & 17.5 & 690 & 5.8 & .38 & 6.8 & 260 & 95 & 513 \\
\hline $12-06-89$ & 25.0 & 405 & 5.9 & .43 & 6.1 & 140 & 123 & 373 \\
\hline $1-24-90$ & 24.5 & 535 & 6.0 & .38 & 6.1 & 150 & 119 & 384 \\
\hline $3-07-90$ & 24.0 & 574 & 6.0 & 1.4 & 5.7 & 160 & 118 & 396 \\
\hline $4-18-90$ & 26.5 & 571 & 6.0 & .44 & 5.5 & 160 & 119 & 390 \\
\hline $5-25-90$ & 25.5 & 545 & 6.0 & .46 & 5.7 & 140 & 127 & 383 \\
\hline $6-26-90$ & 27.5 & 584 & 6.1 & .56 & 5.6 & 130 & 128 & 372 \\
\hline $8-10-90$ & 27.0 & 640 & 6.0 & .61 & 5.0 & 120 & 121 & 364 \\
\hline $10-05-90$ & 27.0 & 505 & 6.1 & .54 & 5.7 & 64 & 177 & 309 \\
\hline \multicolumn{9}{|c|}{ Agrico-9 Creek basin (clay-settling) surficial aquifer system well 12} \\
\hline $11-30-88$ & 24.0 & 185 & -- & 0.01 & 28 & 1.1 & 11 & 117 \\
\hline 4-12-89 & 20.5 & 220 & 5.7 & .03 & 29 & 1.8 & 22 & -- \\
\hline $5-09-89$ & 25.5 & 238 & 5.6 & .02 & 27 & 1.9 & 17 & 100 \\
\hline $6-08-89$ & 28.0 & 235 & 5.6 & .03 & 26 & 2.3 & 22 & 113 \\
\hline $7-13-89$ & 28.5 & 240 & 5.5 & .01 & 26 & 1.3 & 20 & 109 \\
\hline $8-10-89$ & 28.5 & 239 & 5.5 & .05 & 26 & 1.4 & 15 & 106 \\
\hline $9-07-89$ & 30.0 & 216 & 5.5 & .09 & 27 & 1.5 & 13 & 115 \\
\hline $10-16-89$ & 27.5 & 220 & 5.5 & .02 & 26 & 1.2 & 14 & 106 \\
\hline $12-05-89$ & 22.0 & 190 & 5.5 & .02 & 27 & 1.5 & 22 & 105 \\
\hline $1-22-90$ & 24.5 & 191 & 5.5 & .02 & 27 & 1.5 & 11 & 101 \\
\hline $3-05-90$ & 24.5 & 220 & 5.4 & .06 & 26 & 1.6 & 16 & 102 \\
\hline $4-16-90$ & 24.0 & 221 & 5.6 & .09 & 26 & 1.5 & 17 & 97 \\
\hline $5-24-90$ & 25.5 & 190 & 5.5 & .03 & 27 & 1.7 & 17 & 94 \\
\hline $6-27-90$ & 26.0 & 218 & 5.6 & .04 & 25 & 1.7 & 16 & 105 \\
\hline $8-17-90$ & 28.5 & 238 & 5.5 & .04 & 25 & 1.4 & 25 & 102 \\
\hline $10-26-90$ & 23.0 & 240 & 5.4 & .10 & 26 & 1.2 & 22 & 103 \\
\hline \multicolumn{9}{|c|}{ CFI-1 Creek basin (sand-clay settling) surficial aquifer system well 1} \\
\hline $11-30-88$ & 24.5 & 663 & -- & $<.01$ & 4.6 & 1.7 & 267 & 330 \\
\hline $4-12-89$ & 24.5 & 730 & 6.9 & $<.01$ & 8.0 & .70 & 290 & 327 \\
\hline $5-10-89$ & 26.5 & 600 & 6.6 & .01 & 5.7 & .40 & 352 & 317 \\
\hline $6-09-89$ & 28.0 & 705 & 6.7 & $<.01$ & 5.2 & .80 & 343 & 316 \\
\hline $7-12-89$ & 28.0 & 730 & 6.8 & .01 & 5.2 & 2.2 & 333 & 304 \\
\hline $8-14-89$ & -- & -. & $-\cdot$ & $<.01$ & 5.5 & .20 & 330 & 305 \\
\hline $9-06-89$ & 30.0 & 656 & 6.6 & $<.02$ & 5.3 & .90 & 322 & 310 \\
\hline $10-18-89$ & 28.0 & 637 & 6.4 & $<.01$ & 5.4 & .60 & 319 & 296 \\
\hline $12-06-89$ & 26.5 & 733 & 6.6 & $<.01$ & 4.2 & -- & 300 & 292 \\
\hline $1-25-90$ & -- & 675 & 6.7 & $<.01$ & 4.9 & .30 & 322 & 305 \\
\hline $3-07-90$ & 24.5 & 691 & 6.6 & $<.01$ & 4.8 & .90 & 331 & 308 \\
\hline $4-18-90$ & 26.5 & 715 & 6.6 & .01 & 4.9 & .30 & 328 & 306 \\
\hline $5-29-90$ & 26.0 & 696 & 6.6 & .02 & 5.2 & .30 & 274 & 299 \\
\hline $7-05-90$ & 27.0 & 682 & 6.6 & .01 & 8.4 & -- & 317 & 292 \\
\hline $8-17-90$ & 27.0 & 640 & 6.6 & $<.01$ & 1.6 & .60 & 317 & 291 \\
\hline $10-12-90$ & 27.5 & 635 & 6.3 & .02 & 5.8 & .70 & 303 & 282 \\
\hline
\end{tabular}


Table 7. Physical and chemical characteristics of water from the surficial aquifer system at the eight study basins--bimonthly samples--Continued

\begin{tabular}{|c|c|c|c|c|c|c|c|c|}
\hline Date & $\begin{array}{c}\text { Water } \\
\text { temperature } \\
\left({ }^{\circ} \mathrm{C}\right)\end{array}$ & $\begin{array}{c}\text { Specific } \\
\text { conductance } \\
(\mu \mathrm{S} / \mathrm{cm})\end{array}$ & $\begin{array}{c}\mathrm{pH} \\
\text { (standard } \\
\text { units) }\end{array}$ & $\begin{array}{c}\text { Ortho- } \\
\text { phosphorus } \\
\text { (mg/L as } \mathrm{P} \text { ) }\end{array}$ & $\begin{array}{c}\text { Chloride } \\
(\mathrm{mg} / \mathrm{L} \\
\text { as } \mathrm{P})\end{array}$ & $\begin{array}{c}\text { Sulfate } \\
(\mathrm{mg} / \mathrm{L} \\
\left.\text { as } \mathrm{SO}_{4}\right)\end{array}$ & $\begin{array}{l}\text { Alkalinity } \\
(\mathrm{mg} / \mathrm{L} \\
\left.\text { as } \mathrm{CaCO}_{3}\right)\end{array}$ & $\begin{array}{c}\text { Dissolved } \\
\text { solids } \\
\text { (mg/L) }\end{array}$ \\
\hline
\end{tabular}

Agrico-4 Creek basin (overburden-capped sand-tailings) surficial aquifer system well 2

$\begin{array}{rrrcccccc}11-16-88 & 23.5 & 595 & 6.9 & .04 & 11 & 2.6 & 288 & 258 \\ 4-12-89 & 25.0 & 580 & . . & .01 & 15 & 1.1 & 263 & 234 \\ 5-09-89 & 23.0 & 540 & 6.8 & .02 & 13 & 1.2 & 226 & 218 \\ 6-12-89 & 28.0 & 580 & 6.8 & .02 & 14 & 1.1 & 254 & 222 \\ 7-12-89 & 24.5 & 520 & 7.1 & .02 & 14 & .60 & 257 & 230 \\ 8-10-89 & 27.5 & 560 & 7.1 & .01 & 14 & 3.3 & 269 & 245 \\ 9-05-89 & 28.0 & 600 & 7.3 & .01 & 14 & 4.2 & 277 & 241 \\ 10-13-89 & 25.5 & 499 & 7.0 & .01 & 14 & 3.2 & 280 & 262 \\ 12-04-89 & 17.5 & 460 & 7.1 & .02 & 9.8 & 1.3 & 225 & 293 \\ 1-19-90 & 24.0 & 602 & 7.0 & .01 & 14 & .60 & 284 & 247 \\ 3-01-90 & 21.0 & -- & 7.1 & .02 & 13 & .70 & 283 & 238 \\ 4-12-90 & 18.0 & 579 & 7.1 & .01 & 14 & .50 & 283 & 240 \\ 5-23-90 & 24.0 & 589 & 7.0 & .01 & 13 & .60 & 236 & 243 \\ 6-28-90 & 28.5 & 242 & 6.9 & .01 & 12 & .40 & 297 & 261 \\ 8-09-90 & 28.0 & 633 & 7.0 & .01 & 12 & .60 & 285 & 251 \\ 10-05-90 & 27.0 & 620 & 6.8 & .02 & 13 & .04 & 286 & 249\end{array}$

Agrico-1 Creek basin (contoured-overburden) surficial aquifer system well 11

\begin{tabular}{|c|c|c|c|c|c|c|c|c|}
\hline $11-18-88$ & 26.0 & 177 & 5.1 & 3.1 & 18 & 1.9 & 31 & 189 \\
\hline $4-12-89$ & 24.5 & 179 & 5.2 & 2.1 & 9.6 & 3.3 & 21 & 173 \\
\hline $5-10-89$ & 27.0 & 183 & 5.1 & 1.7 & 19 & 3.1 & 19 & 160 \\
\hline $6-08-89$ & 29.0 & 203 & 5.2 & 1.8 & 18 & 2.6 & 25 & 175 \\
\hline $7-14-89$ & 28.0 & 180 & 5.4 & 2.0 & 18 & 1.6 & 19 & 184 \\
\hline $8-11-89$ & 29.5 & 190 & 5.0 & 1.1 & 19 & 1.5 & 25 & 195 \\
\hline $9-07-89$ & 28.0 & 195 & 5.2 & 1.9 & 19 & 1.6 & 16 & 182 \\
\hline $10-17-89$ & 27.5 & 177 & 5.1 & 2.0 & 18 & .70 & 20 & 187 \\
\hline $12-05-89$ & 25.0 & 190 & 5.2 & 1.1 & 20 & 6.2 & 15 & 164 \\
\hline $1-23-90$ & 23.0 & 178 & 5.6 & .88 & -- & -- & 11 & -- \\
\hline $3-06-90$ & 24.0 & 178 & 5.2 & 1.5 & 18 & 3.8 & 14 & 160 \\
\hline $4-17-90$ & 24.0 & 178 & 5.2 & 1.6 & 17 & 8.9 & 17 & 155 \\
\hline $5-24-90$ & 28.4 & 176 & 5.1 & 1.4 & 17 & 10 & 19 & 159 \\
\hline $7-03-90$ & 27.5 & 175 & 5.1 & 1.9 & 19 & 10 & 23 & 166 \\
\hline $8-13-90$ & 27.5 & 180 & -- & 1.0 & 17 & 7.9 & 18 & 171 \\
\hline $10-12-90$ & 27.5 & 172 & 4.9 & 2.2 & 13 & .50 & 18 & 191 \\
\hline
\end{tabular}

Concentrations of sodium were below the FDER primary drinking water standard of $160 \mathrm{mg} / \mathrm{L}$ and ranged from 3.8 to $18 \mathrm{mg} / \mathrm{L}$ in the eight study basins. Sodium concentrations in ground water were similar at the unmined and the reclaimed basins (table 6).

Magnesium concentrations in water from the surficial aquifer system were higher in the reclaimed basins than in the unmined basins. Concentrations ranged from 1.3 to $5.1 \mathrm{mg} / \mathrm{L}$ in ground-water samples collected at the unmined basins and from 3.1 to $46 \mathrm{mg} / \mathrm{L}$ in samples collected at the reclaimed basins. High concentrations of magnesium could reflect the use of water from the Upper Floridan aquifer to transport the sands and clays to the reclamation sites.
Iron concentrations exceeded the FDER secondary drinking water standard of $0.3 \mathrm{mg} / \mathrm{L}$ in all ground-water samples, except at the unmined IMC Creek basin. Iron concentrations ranged from 0.19 to $10 \mathrm{mg} / \mathrm{L}$ at the three unmined basins and from 2.7 to $14 \mathrm{mg} / \mathrm{L}$ at the reclaimed basins.

Concentrations of major constituents in water samples collected from the surficial aquifer system at the reclaimed basins generally exceeded background levels that were reported for the unmined basins. Concentrations of the major constituents varied among the reclaimed basins and were highest at the Mobil Creek (clay-settling) basin. 

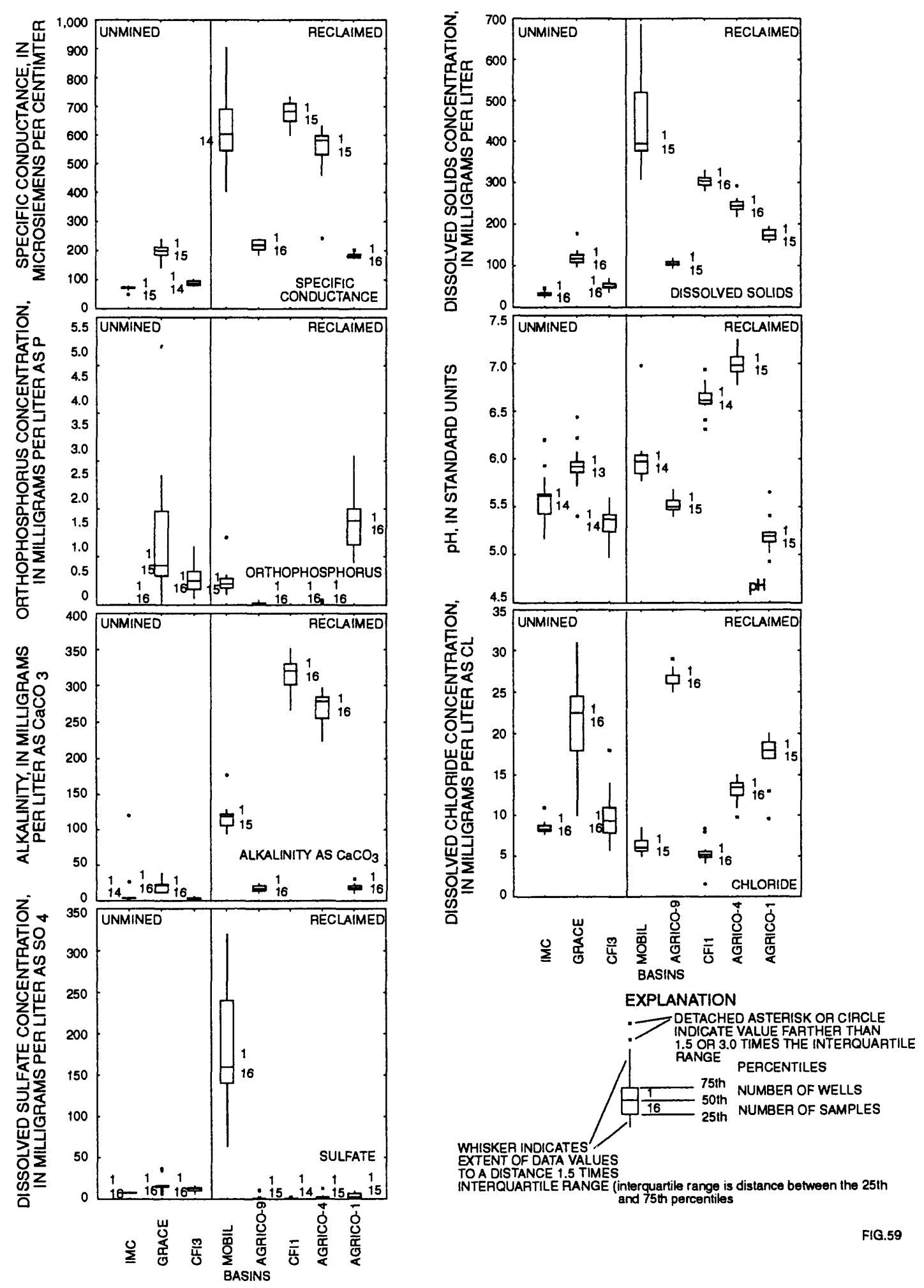

Figure 59. Distribution of values and concentrations of selected properties and constituents in water from the surficial aquifer system at study basins in unmined and reclaimed areas. 


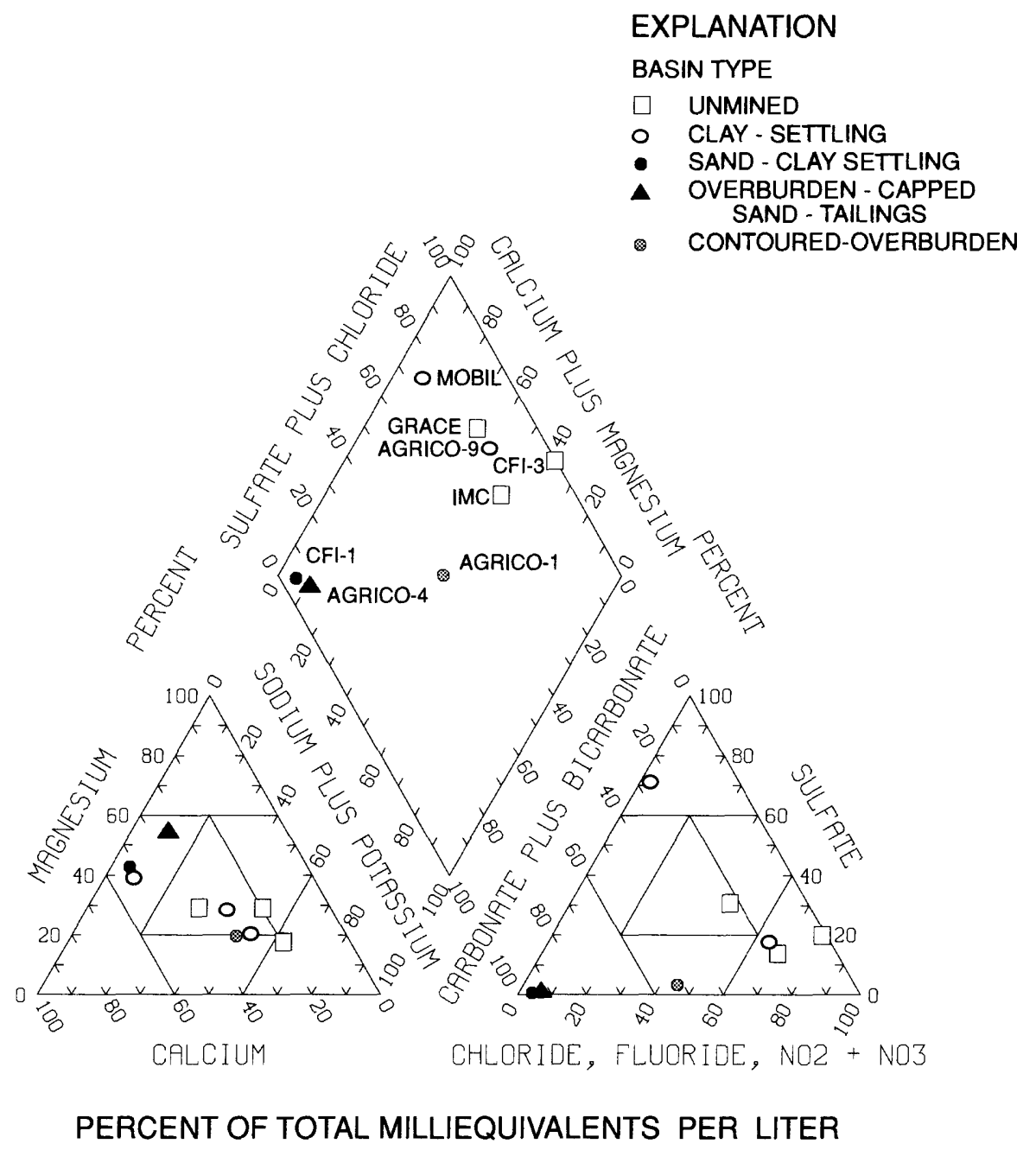

Figure 60. Chemical composition of water from the surficial aquifer in the eight study basins.

The chemical compositions of water from the surficial aquifer system in the various basins are shown in the trilinear diagram of figure 60 . The diagram shows that the general chemical composition of ground water at the three unmined sites is similar, whereas the composition of ground water varies among the reclaimed sites. Water types at the reclaimed basins vary from sodium chloride to calcium carbonate to calcium sulfate.

Water from the surficial aquifer system at the CFI-1 Creek basin (sand-clay settling) and the Agrico-4 Creek basin (overburden-capped sand-tailings) was predominantly calcium magnesium bicarbonate. This might be related to the use of water from the Upper Floridan aquifer to create slurries in which to transport the phosphate matrix to the beneficiation plant for processing and to return the separated waste sand and clays to the mined-out pits during reclamation. The chemical composition of water from the surficial aquifer system at the more recent of the reclaimed clay-settling basins, Agrico-9 Creek, is similar to that in the unmined basins. Calcium and magnesium sulfate were the predominant ions in ground water at the Mobil Creek basin, which is the older and more consolidated clay-settling basin.

\section{Trace Elements}

Concentrations of most trace elements were higher in the water samples from the surficial aquifer system in the reclaimed basins than in samples from this aquifer system in the unmined basins during this study. Trace elements analyzed included arsenic, iodide, barium, beryllium, boron, cadmium, cobalt, copper, lead, manganese, molybdenum, nickel, silver, strontium, vanadium, zinc, lithium, and mercury.

Concentrations of arsenic, boron, cobalt, manganese, and mercury in water samples from the surficial aquifer system in the reclaimed basins were greater than the concentrations in samples from the unmined basins. Dissolved manganese and total lead concentrations were the only trace elements that 
were detected in concentrations that exceeded the FDER drinking water standards. Concentrations of manganese were 150 and $140 \mu \mathrm{g} / \mathrm{L}$ at the Mobil Creek and the CFI-1 Creek reclaimed basins, respectively, exceeding the $50-\mu \mathrm{g} / \mathrm{L}$ FDER secondary drinking water standard (table 6). The concentration of lead in water samples from the surficial aquifer system at the Agrico-1 Creek basin was $96 \mu \mathrm{g} / \mathrm{L}$, which exceeded the $50-\mu \mathrm{g} / \mathrm{L}$ FDER primary drinking water standard.

\section{Radiochemicals}

Phosphate ore is a source of radioactivity, the release of energy and alpha, beta, and gamma particles of an element to form a more stable configuration. Naturally occurring uranium-238 disintegrates in stages to form a series of radioactive nuclide "daughter" products, which include isotopes of radium and radon that are major emitters of alpha activity in natural waters. Radium decays to form radon, a watersoluble, alpha-emitting gas. Gross-alpha activity in water from the surficial aquifer system at the unmined basins, IMC Creek, Grace Creek, and CFI-3 Creek, was 4.0, 53, and 37 $\mathrm{pCi} / \mathrm{L}$, respectively (table 6). Reported background levels of gross-alpha activity in water from this aquifer in the study area rarely exceed the FDER primary drinking water standard of $15 \mathrm{pCi} / \mathrm{L}$. The relatively high gross-alpha activities of 53 and $37 \mathrm{pCi} / \mathrm{L}$ at the Grace Creek and CFI-3 Creek basins were detected in single, nonreplicated measurements of water samples from wells in each basin and are attributed to the natural emissions from undisturbed phosphate-ore deposits in the aquifer system. Gross-alpha activities in ground-water samples from the reclaimed basins ranged from 1.9 to 5.2 $\mathrm{pCi} / \mathrm{L}$. Gross-beta activities in ground-water samples from the three unmined basins ranged from 5.0 to $10 \mathrm{pCi} / \mathrm{L}$ and were similar to the gross-beta activities in ground-water samples from the reclaimed basins $(0.8$ to $5.4 \mathrm{pCi} / \mathrm{L})$. Radium-226 activities in ground-water samples from the eight study basins ranged from 0.64 to $2.1 \mathrm{pCi} / \mathrm{L}$. Activities of uranium-234 and uranium-238 in ground-water samples from the unmined basins were at or below detection limits. Ground-water samples from the Agrico-1 Creek and Mobil Creek basins were the only samples that had detectable uranium-234 and uranium-238 activities. Samples from the Agrico-1 Creek basin had a uranium-234 activity of $0.70 \mathrm{pCi} / \mathrm{L}$ and a uranium-238 activity of $0.60 \mathrm{pCi} / \mathrm{L}$. Samples from the Mobil Creek basin had uranium-234 and uranium-238 activities of $0.30 \mathrm{pCi} / \mathrm{L}$.

\section{Water in the Intermediate Aquifer System}

Water in the intermediate aquifer system at six of the study basins was sampled bimonthly from December 1988 to October 1990 and analyzed for specific conductance, $\mathrm{pH}$, alkalinity, and concentrations of dissolved solids, orthophosphorus, chloride, and sulfate. Water-quality sampling of the intermediate aquifer system was not possible at two basins, IMC Creek and Agrico-9 Creek, because of problems with the IMC-DP well and abnormally high $\mathrm{pH}$ levels in water from well AG9-DP, which were probably due to cement in the well. Boxplot diagrams in figure 61 and results of analyses presented in table 8 give the range of selected properties and constituent concentrations in water from this aquifer system at the six basins sampled.

Field and laboratory analyses of bimonthly samples from the intermediate aquifer system indicate similar concentrations of most constituents in water from this aquifer system at the unmined Grace Creek basin and at the CFI-3 Creek basin. Specific conductance, alkalinity, and concentrations of dissolved solids were higher at Mobil Creek basin than at the unmined basins and the other reclaimed basins. The boxplot diagrams for the six basins show that specific conductance ranged from 199 to $786 \mu \mathrm{S} / \mathrm{cm}$, dissolved solids from 121 to $481 \mathrm{mg} / \mathrm{L}$, orthophosphorus from 0.01 to 0.18 $\mathrm{mg} / \mathrm{L}, \mathrm{pH}$ from 5.5 to 9.1 standard units, alkalinity from 77 to $437 \mathrm{mg} / \mathrm{L}$, chloride from 4.5 to $16 \mathrm{mg} / \mathrm{L}$, and sulfate from 0.4 to $25 \mathrm{mg} / \mathrm{L}$ (fig. 61 and table 8). Concentrations of all constituents analyzed were within the FDER standards for primary and secondary drinking waters, although $\mathrm{pH}$ values at the Grace Creek and Agrico-4 Creek basins were slightly higher than the maximum allowable limit of 8.5 standard units. The higher $\mathrm{pH}$ values are attributed to residual cement remaining in the well casing after construction.

\section{Surface Water}

Surface-water samples were collected for waterquality analyses at most of the study basins as part of the reconnaissance sampling during base-flow and high-flow conditions (table 9). The CFI-1 Creek basin (sand-clay settling) could not be sampled because of a lack of flow, and only two of the reclaimed basins, Agrico-4 Creek and Agrico-1 Creek, had sufficient flow to collect samples during base-flow conditions. High-flow samples were collected at all basins, except CFI-1 Creek and CFI-3 Creek.

Measurements of specific conductance made during the bimonthly sampling of the surface-water sites during September 1988 through October 1990 are listed in table 10 and are shown in boxplot diagrams in figure 62 . The specificconductance values ranged from 65 to $320 \mu \mathrm{S} / \mathrm{cm}$ at the unmined basins and from 60 to $588 \mu \mathrm{S} / \mathrm{cm}$ at the reclaimed basins, less than the FDER class I (Florida Department of Environmental Regulation, 1992) potable surface-water standard maximum level of $1,275 \mu \mathrm{S} / \mathrm{cm}$.

Color of surface-water samples collected at all of the basins exceeded the FDER drinking water standard of $15 \mathrm{Pt}$-Co units. Color ranged from 20 to $240 \mathrm{Pt}$-Co units in surface-water samples from the unmined basins and from 35 to $320 \mathrm{Pt}-\mathrm{Co}$ units in surface-water samples from the 

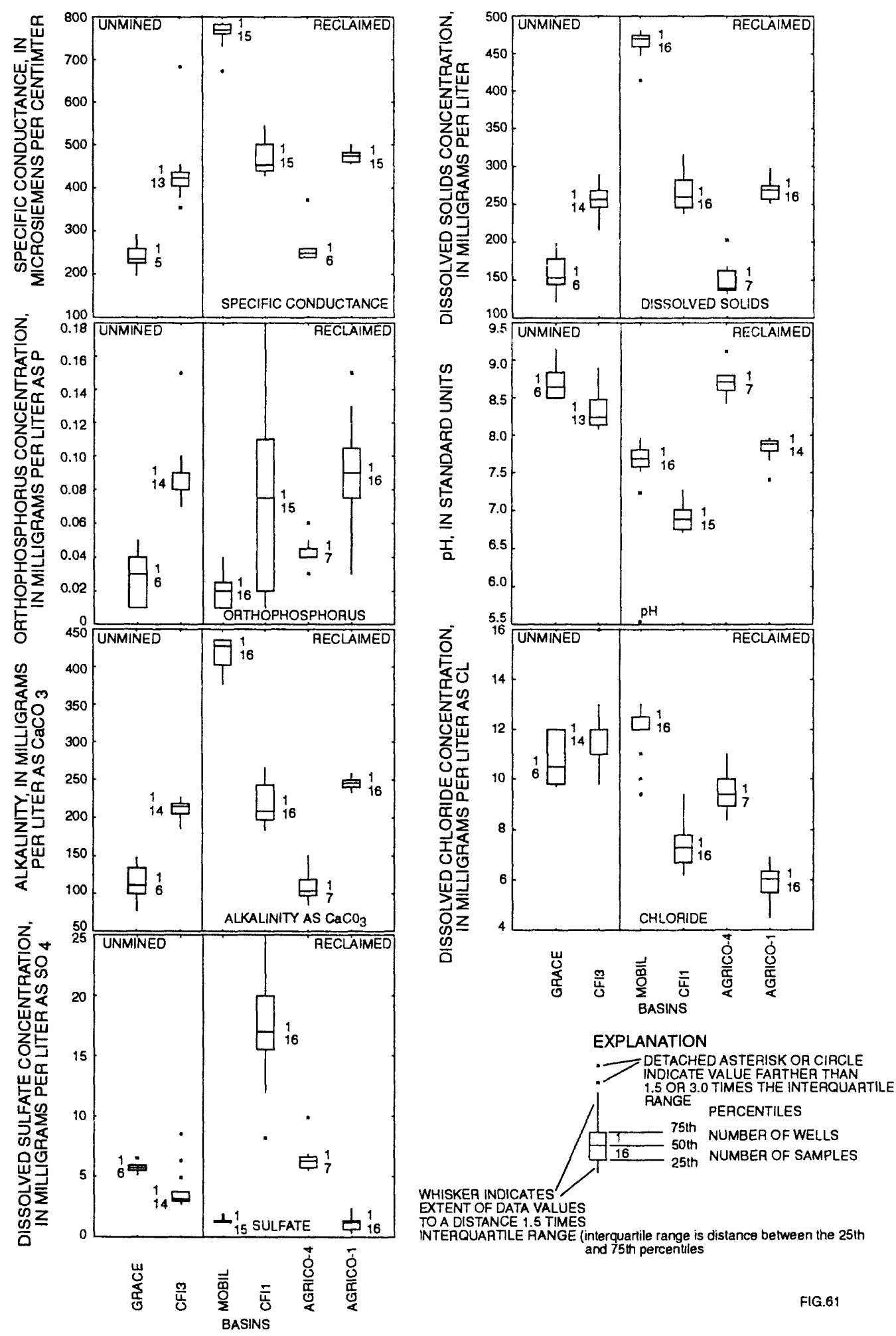

Figure 61. Distribution of values and concentrations of selected properties and constituents in water from the intermediate aquifer system at study basins in unmined and reclaimed areas. 
Table 8. Physical and chemical characteristics of water from the intermediate aquifer system at six study basins--bimonthly samples

$\left[{ }^{\circ} \mathrm{C}\right.$, degrees Celsius; $\mu \mathrm{S} / \mathrm{cm}$, microsiemens per centimeter at $25{ }^{\circ} \mathrm{C} ; \mathrm{mg} / \mathrm{L}$, milligrams per liter; --, not sampled]

\begin{tabular}{|c|c|c|c|c|c|c|c|c|}
\hline Date & $\begin{array}{c}\text { Water } \\
\text { temperature } \\
\left({ }^{\circ} \mathrm{C}\right)\end{array}$ & $\begin{array}{c}\text { Specific } \\
\text { conductance } \\
(\mu \mathrm{S} / \mathrm{cm})\end{array}$ & $\begin{array}{c}\mathrm{pH} \\
\text { (standard } \\
\text { units) }\end{array}$ & $\begin{array}{c}\text { Ortho- } \\
\text { phosphorus } \\
\text { (mg/L as } \mathrm{P} \text { ) }\end{array}$ & $\begin{array}{c}\text { Chloride } \\
\text { (mg/L } \\
\text { as P) }\end{array}$ & $\begin{array}{l}\text { Sulfate } \\
(\mathrm{mg} / \mathrm{L} \\
\text { as } \mathrm{SO}_{4}\end{array}$ & $\begin{array}{l}\text { Alkalinity } \\
(\mathrm{mg} / \mathrm{L} \\
\left.\text { as } \mathrm{CaCO}_{3}\right)\end{array}$ & $\begin{array}{c}\text { Dissolved } \\
\text { solids } \\
(\mathrm{mg} / \mathrm{L})\end{array}$ \\
\hline \multicolumn{9}{|c|}{ Grace Creek basin (unmined) intermediate aquifer system well } \\
\hline $12-20-88$ & 23.0 & 227 & 8.5 & 0.05 & 10 & 5.9 & 148 & 198 \\
\hline $2-28-90$ & 22.0 & -- & 8.5 & .04 & 11 & 5.1 & 134 & 178 \\
\hline 4-11-90 & 23.0 & 236 & 8.8 & .01 & 12 & 5.5 & 100 & 147 \\
\hline $5-22-90$ & 23.5 & 199 & 9.1 & .01 & 12 & 5.8 & 77 & 121 \\
\hline $7-02-90$ & 25.0 & 292 & 8.5 & .03 & 9.7 & 5.6 & 121 & 160 \\
\hline $8-08-90$ & 25.5 & 260 & 8.8 & .03 & 9.8 & 6.5 & 102 & 145 \\
\hline \multicolumn{9}{|c|}{ CFI- 3 Creek basin (unmined) intermediate aquifer system well } \\
\hline $4-07-89$ & 22.5 & 683 & 8.1 & 0.08 & 16 & 8.5 & 219 & 289 \\
\hline $5-11-89$ & 25.5 & 435 & 8.1 & .08 & 13 & 6.3 & 219 & 263 \\
\hline $6-09-89$ & 26.0 & 355 & 8.9 & .08 & 12 & 4.9 & 219 & 260 \\
\hline $7-18-89$ & -- & -- & -- & .09 & 12 & 3.7 & 227 & 277 \\
\hline $8-11-89$ & 26.0 & 455 & 8.3 & .09 & 12 & 3.7 & 223 & 274 \\
\hline $9-06-89$ & 25.0 & 380 & 8.7 & .09 & 13 & 3.4 & 217 & 270 \\
\hline $12-07-89$ & 24.0 & 405 & 8.5 & .10 & 12 & 2.9 & 215 & 267 \\
\hline $1-25-90$ & 24.0 & 430 & 8.3 & .08 & 12 & 2.9 & 208 & 254 \\
\hline $3-08-90$ & 24.0 & 441 & 8.1 & .09 & 11 & 3.1 & 206 & 253 \\
\hline $4-19-90$ & 23.5 & 418 & 8.2 & .09 & 12 & 3.1 & 205 & 241 \\
\hline $5-29-90$ & 26.5 & 393 & 8.2 & .07 & 10 & 3.0 & 186 & 227 \\
\hline $7-05-90$ & 26.5 & 429 & 8.1 & .09 & 10 & 3.1 & 197 & 233 \\
\hline $8-16-90$ & 27.0 & 415 & 8.4 & .15 & 9.8 & 2.9 & 190 & 217 \\
\hline $10-10-90$ & 25.5 & 437 & 8.2 & .09 & 11 & 2.7 & 215 & 257 \\
\hline
\end{tabular}

Mobil Creek basin (clay-settling) intermediate aquifer system well

$\begin{array}{rcccccccc}4-06-89 & 23.0 & 786 & 7.9 & 0.02 & 12 & 1.8 & 435 & 471 \\ 5-11-89 & 22.5 & 780 & 7.7 & .02 & 12 & 1.6 & 404 & 460 \\ 6-13-89 & 25.0 & 673 & 8.0 & .03 & 13 & 1.3 & 382 & 449 \\ 7-17-89 & -- & -- & 7.8 & .02 & 12 & 1.3 & 436 & 472 \\ 8-09-89 & 26.0 & 760 & 7.6 & .01 & 12 & 1.2 & 436 & 481 \\ 9-06-89 & 24.0 & 770 & 7.5 & .03 & 13 & 1.2 & 436 & 470 \\ 10-20-89 & 21.5 & 732 & 7.6 & .01 & 12 & 1.3 & 437 & 462 \\ 12-06-89 & 22.0 & 780 & 5.5 & .01 & 13 & 1.2 & 428 & 477 \\ 1-24-90 & 22.5 & 760 & 7.7 & .01 & 12 & 1.2 & 436 & 474 \\ 3-07-90 & 22.0 & 769 & 7.6 & .04 & 11 & 1.2 & 413 & 414 \\ 4-18-90 & 25.5 & 785 & 7.6 & .02 & 13 & 1.2 & 419 & 468 \\ 5-25-90 & 24.5 & 752 & 7.8 & .04 & 12 & 1.3 & 385 & 448 \\ 6-26-90 & 26.0 & 782 & 7.9 & .01 & 10 & 1.4 & 402 & 475 \\ 8-10-90 & 25.0 & 782 & 7.7 & .01 & 9.4 & 1.3 & 377 & 459 \\ 10-05-90 & 26.0 & 765 & 7.2 & .02 & 12 & 1.4 & 428 & 478\end{array}$

CFI-1 Creek basin (sand-clay settling) intermediate aquifer system well

$\begin{array}{rrrrrrrrr}4-12-89 & 24.5 & 545 & 7.1 & 0.09 & 6.5 & 16 & 258 & 316 \\ 5-10-89 & 26.0 & 530 & 7.0 & .05 & 6.6 & 19 & 245 & 285 \\ 6-09-89 & 25.0 & 502 & 7.0 & .01 & 6.6 & 13 & 241 & 280 \\ 7-14-89 & 26.0 & 499 & 7.3 & .02 & 7.4 & 15 & 230 & 274 \\ 8-14-89 & 24.0 & -- & -. & .10 & 8.1 & 25 & 184 & 249 \\ 9-06-89 & 28.0 & 441 & 7.0 & -- & 6.2 & 8.2 & 266 & 307 \\ 10-18-89 & 27.5 & 504 & 7.0 & .01 & 7.0 & 12 & 250 & 294 \\ 12-06-89 & 24.5 & 432 & 6.7 & .07 & 7.7 & 23 & 198 & 260 \\ 1-25-90 & 24.5 & 460 & 6.8 & .04 & 7.3 & 19 & 210 & 266 \\ 3-07-90 & 25.5 & 436 & 6.8 & .12 & 7.4 & 21 & 196 & 240 \\ 4-18-90 & 27.0 & 441 & 6.7 & .18 & 7.9 & 20 & 206 & 248 \\ 5-29-90 & 24.5 & 429 & 6.7 & .02 & 8.0 & 20 & 188 & 238 \\ 7-05-90 & 26.0 & 448 & 6.8 & .12 & 6.9 & 17 & 198 & 241 \\ 8-17-90 & 24.5 & 450 & 6.9 & .08 & 6.8 & 16 & 204 & 244 \\ 10-12-90 & 27.5 & 458 & 6.8 & .011 & 9.4 & 16 & 209 & 254\end{array}$


Table 8. Physical and chemical characteristics of water from the intermediate aquifer system at six study basins--bimonthly samples--Continued

\begin{tabular}{|c|c|c|c|c|c|c|c|c|}
\hline Date & $\begin{array}{c}\text { Water } \\
\text { temperature } \\
\left({ }^{\circ} \mathrm{C}\right)\end{array}$ & $\begin{array}{l}\text { Specific } \\
\text { conductance } \\
(\mu \mathrm{S} / \mathrm{cm})\end{array}$ & $\begin{array}{c}\mathrm{pH} \\
\text { (standard } \\
\text { units) }\end{array}$ & $\begin{array}{c}\text { Ortho- } \\
\text { phosphorus } \\
\text { (mg/L as } \mathrm{P} \text { ) }\end{array}$ & $\begin{array}{c}\text { Chloride } \\
(\mathrm{mg} / \mathrm{L} \\
\text { as } \mathrm{P})\end{array}$ & $\begin{array}{l}\text { Sulfate } \\
(\mathrm{mg} / \mathrm{L} \\
\text { as } \mathrm{SO}_{4}\end{array}$ & $\begin{array}{l}\text { Alkalinity } \\
(\mathrm{mg} / \mathrm{L} \\
\left.\text { as } \mathrm{CaCO}_{3}\right)\end{array}$ & $\begin{array}{c}\text { Dissolved } \\
\text { solids } \\
\text { (mg/L) }\end{array}$ \\
\hline \multicolumn{9}{|c|}{ Agrico-4 Creek basin (overburden-capped sand-tailings) intermediate aquifer system well } \\
\hline $1-24-90$ & 24.0 & 373 & 9.1 & 0.06 & 11 & 5.5 & 151 & 203 \\
\hline 3-01-90 & 23.5 & -- & 8.6 & .04 & 10 & 6.0 & 125 & 168 \\
\hline $4-12-90$ & 23.5 & 259 & 8.6 & .03 & 10 & 9.9 & 114 & 157 \\
\hline $5-23-90$ & 24.5 & 239 & 8.7 & .04 & 9.1 & 6.3 & 104 & 139 \\
\hline $6-28-90$ & 25.0 & 240 & 8.8 & .04 & 8.8 & 6.4 & 98 & 137 \\
\hline $8-09-90$ & 25.0 & 240 & 8.8 & .05 & 8.4 & 6.9 & 97 & 137 \\
\hline $10-04-90$ & 29.5 & 260 & 8.4 & .24 & 9.4 & 5.5 & 86 & 132 \\
\hline \multicolumn{9}{|c|}{ Agrico-1 Creek basin (contoured-overburden) intermediate aquifer system well } \\
\hline $12-21-88$ & 24.5 & $\cdots$ & -- & 0.03 & 5.8 & 2.3 & 259 & 298 \\
\hline $4-12-89$ & 22.0 & 490 & 7.9 & .05 & 4.5 & 1.8 & 253 & 252 \\
\hline $5-10-89$ & 27.0 & 485 & 7.8 & .10 & 6.1 & 1.4 & 255 & 276 \\
\hline 6-08-89 & 26.5 & 500 & 7.9 & .07 & 5.7 & 1.4 & 249 & 280 \\
\hline $7-14-89$ & 23.5 & 495 & 7.9 & .08 & 6.6 & .70 & 250 & 274 \\
\hline $8-11-89$ & 24.5 & 470 & 7.8 & .07 & 6.5 & .50 & 237 & 273 \\
\hline $9-07-89$ & 25.0 & 457 & 7.7 & .09 & 5.8 & .40 & 247 & 283 \\
\hline $10-17-89$ & 23.5 & 462 & 7.9 & .08 & 6.1 & .40 & 248 & 270 \\
\hline $12-05-89$ & 21.0 & 480 & 8.0 & .09 & 5.3 & .60 & 242 & 268 \\
\hline $1-23-90$ & 22.0 & 480 & 8.0 & .08 & 6.0 & 1.0 & 245 & 271 \\
\hline $3-06-90$ & 22.5 & 464 & 7.9 & .10 & 6.3 & 1.2 & 243 & 259 \\
\hline $4-17-90$ & 22.5 & 459 & 7.8 & .11 & 6.1 & 1.2 & 246 & 260 \\
\hline $5-24-90$ & 25.0 & 459 & 7.9 & .10 & 6.4 & 1.3 & 242 & 263 \\
\hline $7-03-90$ & 25.0 & 460 & 7.7 & .15 & 5.2 & 1.2 & 238 & 253 \\
\hline $8-13-90$ & 25.0 & 460 & -- & .13 & 5.0 & 1.2 & 237 & 256 \\
\hline $10-12-90$ & 24.5 & 475 & 7.4 & .13 & 6.9 & .80 & 234 & 255 \\
\hline
\end{tabular}

reclaimed basins (table 9). High color is common in many natural streams in Florida.

\section{Nitrogen and Phosphorus}

Surface-water samples collected at the study basins were analyzed for nitrogen and phosphorus species to compare concentrations in the reclaimed basins with background concentrations in unmined basins. Total nitrite plus nitrate concentrations were low in surface waters at all of the study basins. IMC Creek and Grace Creek basins were the only basins that had concentrations greater than the detection limit of $0.02 \mathrm{mg} / \mathrm{L}$. Concentration of nitrite plus nitrate was $0.03 \mathrm{mg} / \mathrm{L}$ during high flow at the IMC Creek basin and 0.90 and $0.14 \mathrm{mg} / \mathrm{L}$ during base-flow and highflow conditions, respectively, at the Grace Creek basin (table 9). Concentrations of ammonia as $\mathrm{N}$ were less than $0.40 \mathrm{mg} / \mathrm{L}$ at all of the study basins. Concentrations of total organic nitrogen in all streamflow samples ranged from 0.53 to $1.7 \mathrm{mg} / \mathrm{L}$.

Boxplot diagrams in figure 62 show that orthophosphorus concentrations in surface-water samples were similar at the three unmined and the two reclaimed basins sampled bimonthly. Concentrations ranged from 0.06 to $0.74 \mathrm{mg} / \mathrm{L}$ at the five sites shown in figure 62 , but orthophosphorus concentrations were as high as $2.5 \mathrm{mg} / \mathrm{L}$ in one of the few samples collected in the Mobil Creek basin and $0.99 \mathrm{mg} / \mathrm{L}$ in one of two samples collected in the Agrico-9 Creek basin.

\section{Major Constituents}

The major constituents in water from the streams in the study basins are the cations-calcium, magnesium, sodium, and potassium - and the anions-sulfate, chloride, fluoride, nitrate, and carbonate or bicarbonate that contribute to alkalinity. Alkalinity of surface-water samples from the unmined basins ranged from below the detection limit of 0.1 to $105 \mathrm{mg} / \mathrm{L}$ as $\mathrm{CaCO}_{3}$ (fig. 62 and table 10). Alkalinity in surface-water samples from reclaimed basins ranged from $18 \mathrm{mg} / \mathrm{L}$ at Mobil Creek basin (table 10) to $270 \mathrm{mg} / \mathrm{L}$ at Agrico-4 Creek basin (fig. 62). Concentrations of dissolved solids in water samples from streams in the study basins were less than the FDER class I surface-water standard of $500 \mathrm{mg} / \mathrm{L}$. Dissolved-solids concentrations ranged from 64 to $206 \mathrm{mg} / \mathrm{L}$ at the unmined basins and from 70 to $358 \mathrm{mg} / \mathrm{L}$ at the reclaimed basins (fig. 62 and 
Table 9. Physical and chemical characteristics of water from streams in the study basins--reconnaissance samples $\left[\mathrm{ft}^{3} / \mathrm{s}\right.$, cubic foot per second; ${ }^{\circ} \mathrm{C}$, degrees Celsius; NTU, nephelometric turbidity units; Pt-Co, platinum-cobalt; mg/L, milligrams per liter; $\mu \mathrm{g} / \mathrm{L}$, micrograms per liter; <, less than; --, not sampled]

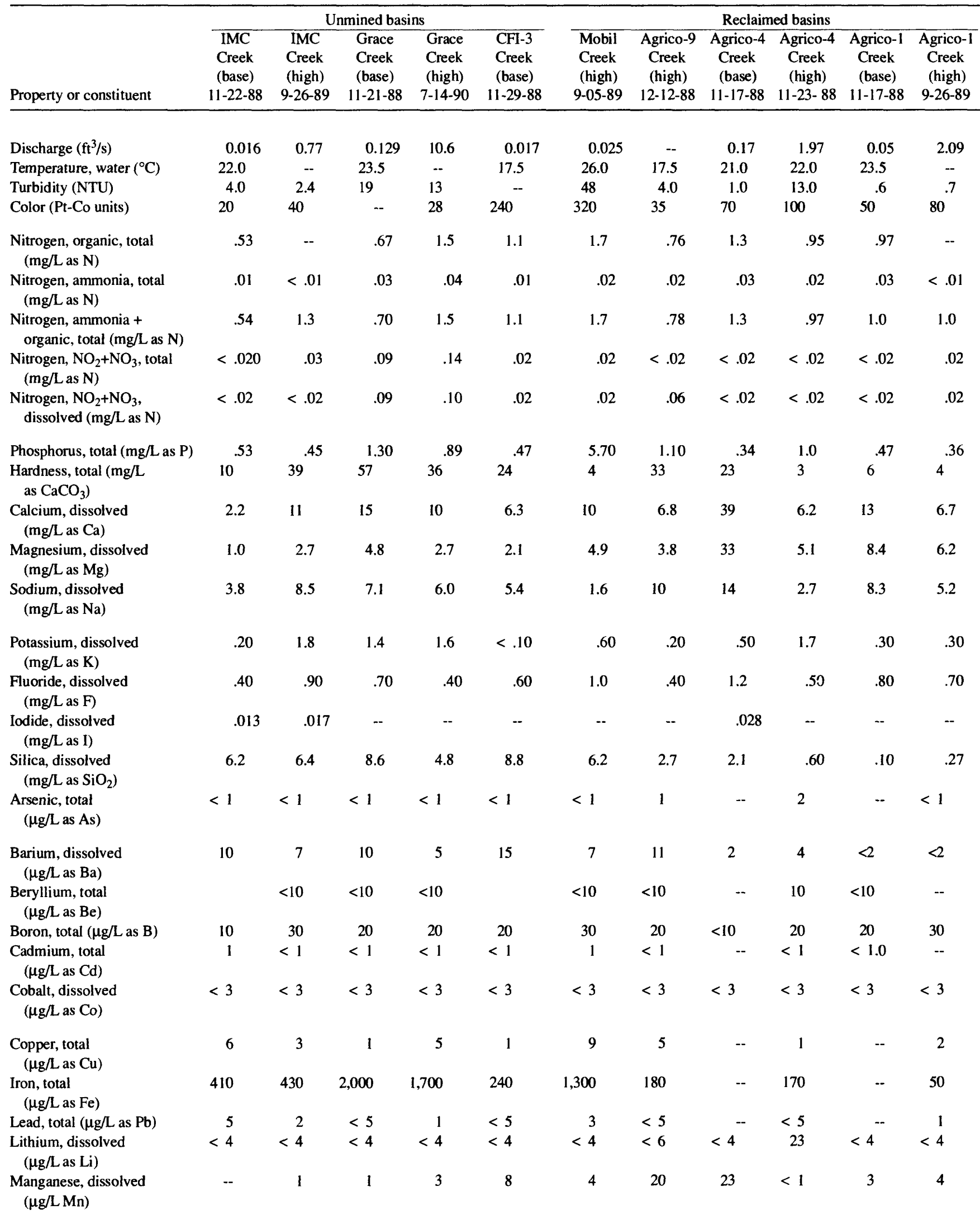


Table 9. Physical and chemical characteristics of water from streams in the study basins--reconnaissance samples--Continued

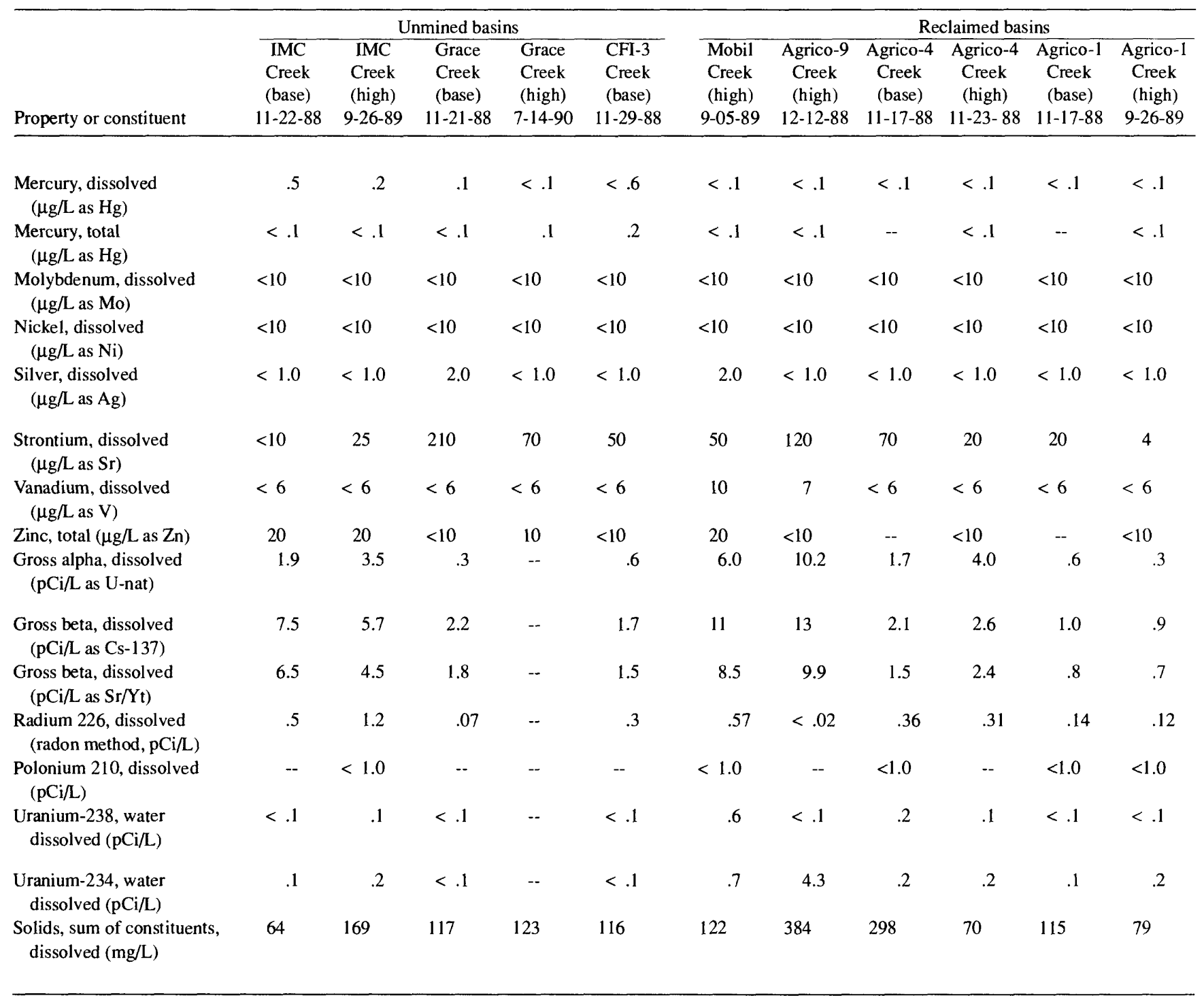

table 10). The dissolved-solids concentration in surfacewater samples collected at the Agrico-4 Creek basin were significantly higher than concentrations at the other basins.

Concentrations of most major constituents in water samples collected from streams in the study basins were relatively low and less than the FDER standards for class 1 or class III surface waters. Calcium concentrations in surfacewater samples collected in the study basins during reconnaissance sampling were $15 \mathrm{mg} / \mathrm{L}$ or less at the unmined basins and at all but one of the reclaimed basins. A sample collected at the Agrico-4 Creek basin during base-flow conditions had a calcium concentration of $39 \mathrm{mg} / \mathrm{L}$ (table 9). Chloride concentrations of water samples collected bimonthly from streams in the study basins ranged from 3.5 to $33 \mathrm{mg} / \mathrm{L}$, significantly less than the 250-mg/L FDER class I surface-water standard. Sulfate concentrations in surface-water samples collected at the unmined and at the reclaimed basins ranged from $0.70 \mathrm{mg} / \mathrm{L}$ at Agrico-4 and Agrico-1 Creeks to $76 \mathrm{mg} / \mathrm{L}$ at Agrico-9 Creek (fig. 62 and table 10) and were well below the $250-\mathrm{mg} / \mathrm{L}$ drinking water standard. Concentrations of sodium ranged from 1.6 to $14 \mathrm{mg} / \mathrm{L}$ with no discernible differences between unmined or reclaimed basins (table 9). Concentrations of fluoride in surface-water samples ranged from 0.40 to $1.2 \mathrm{mg} / \mathrm{L}$ and were less than the FDER class III surface-water standard of $10 \mathrm{mg} / \mathrm{L}$ (table 9). Magnesium concentrations generally were higher in water from streams at the reclaimed basins (3.8 to $33 \mathrm{mg} / \mathrm{L}$ ) than at the unmined basins ( 1.0 to $4.8 \mathrm{mg} / \mathrm{L})$. Concentrations of potassium in surface-water samples from all study basins were less than $2.0 \mathrm{mg} / \mathrm{L}$. Silica concentrations in surface-water samples ranged from 0.1 to $8.8 \mathrm{mg} / \mathrm{L}$ and generally were higher at the unmined basins than at the reclaimed basins. Concentrations of dissolved iron 


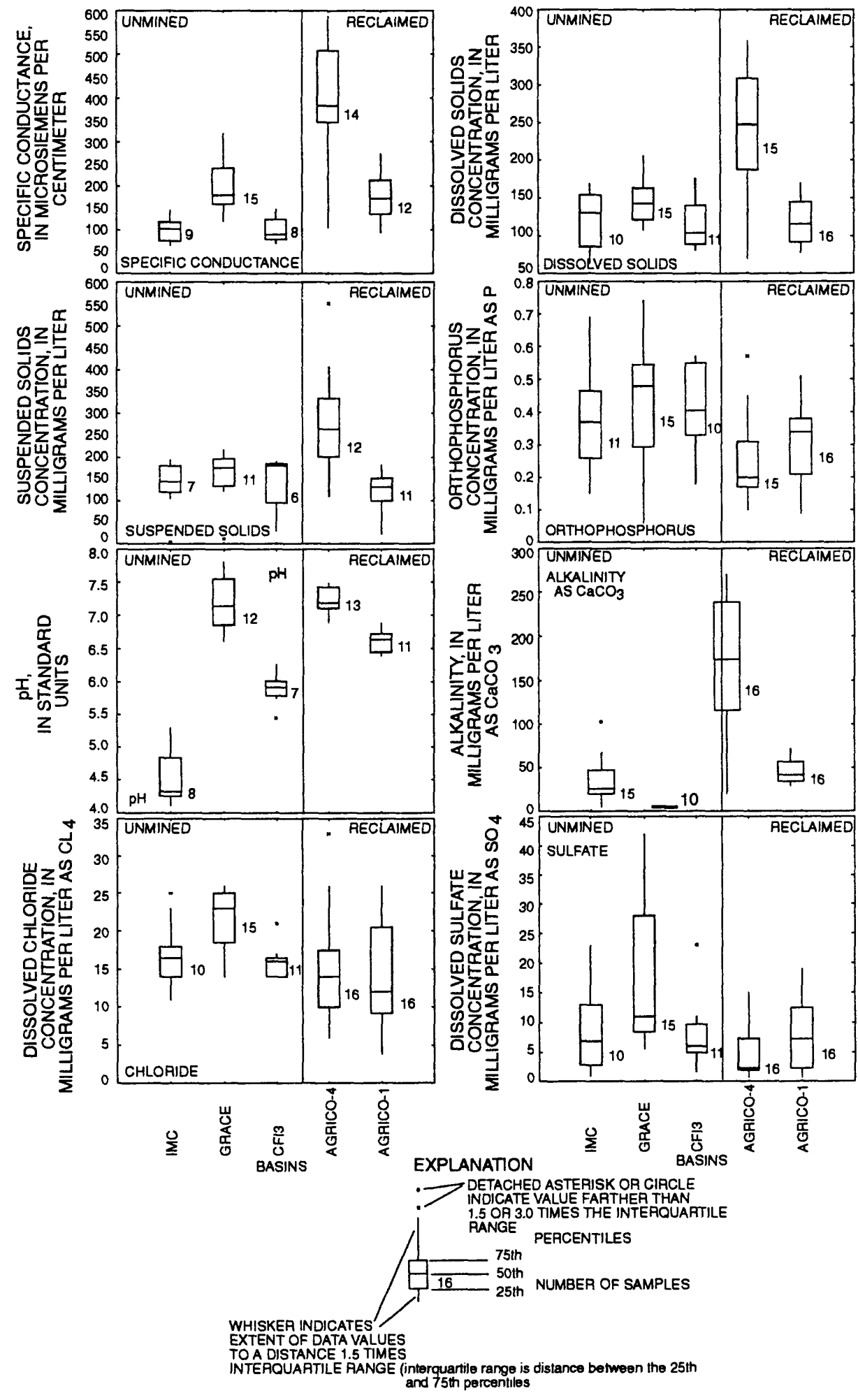

Figure 62. Distribution of values and concentrations of selected properties and constituents in water from streams in study basins at unmined and reclaimed areas. 
Table 10. Physical and chemical characteristics of water from streams in the study basins--bimonthly samples $\left[\mathrm{ft}^{3} / \mathrm{s}\right.$, cubic feet per second; ${ }^{\circ} \mathrm{C}$, degrees Celsius; $\mu \mathrm{S} / \mathrm{cm}$, microsiemens per centimeter at $25^{\circ} \mathrm{C} ; \mathrm{mg} / \mathrm{L}$, milligrams per liter; --, not sampled, $<$ less than]

\begin{tabular}{|c|c|c|c|c|c|c|c|c|c|c|}
\hline Date & $\begin{array}{l}\text { Dis- } \\
\text { charge } \\
\left(\mathrm{ft}^{3} / \mathrm{s}\right)\end{array}$ & $\begin{array}{c}\text { Water } \\
\text { temperature } \\
\left({ }^{\circ} \mathrm{C}\right)\end{array}$ & $\begin{array}{c}\text { Specific } \\
\text { conductance } \\
(\mu \mathrm{S} / \mathrm{cm})\end{array}$ & $\begin{array}{c}\mathrm{pH} \\
\text { (standard } \\
\text { units) }\end{array}$ & $\begin{array}{c}\text { Ortho- } \\
\text { phosphorus } \\
\text { (mg/Las } \mathrm{P})\end{array}$ & $\begin{array}{c}\text { Chloride } \\
\text { (mg/L } \\
\text { as P) }\end{array}$ & $\begin{array}{c}\text { Sulfate } \\
(\mathrm{mg} / \mathrm{L} \\
\left.\text { as } \mathrm{SO}_{4}\right)\end{array}$ & $\begin{array}{l}\text { Alkalinity } \\
(\mathrm{mg} / \mathrm{L} \\
\left.\text { as } \mathrm{CaCO}_{3}\right)\end{array}$ & $\begin{array}{l}\text { Dissolved } \\
\text { solids } \\
(\mathrm{mg} / \mathrm{L})\end{array}$ & $\begin{array}{c}\text { Suspended } \\
\text { solids } \\
(\mathrm{mg} / \mathrm{L})\end{array}$ \\
\hline
\end{tabular}

IMC Creek (unmined) basin

\begin{tabular}{|c|c|c|c|c|c|c|c|c|c|}
\hline $9-23-88$ & -- & - & 86 & 5.3 & 0.69 & -- & -- & -- & -- \\
\hline $11-22-88$ & 0.016 & 22.0 & 74 & 4.3 & .44 & 12 & 2.2 & $<0.1$ & 64 \\
\hline $4-10-89$ & .001 & 30.0 & 65 & -- & .49 & 11 & 1.0 & $<.1$ & 86 \\
\hline $8-09-89$ & .432 & -- & -- & -- & .53 & 25 & 23 & .8 & 165 \\
\hline $9-26-89$ & .768 & -- & - & -- & .43 & 17 & 17 & $<.1$ & 169 \\
\hline $10-10-89$ & .052 & 25.5 & 102 & 4.1 & .34 & 16 & 2.8 & $<.1$ & 126 \\
\hline $11-28-89$ & .120 & 23.0 & 111 & 4.3 & .15 & 23 & 13 & $<.1$ & 154 \\
\hline $1-17-90$ & .025 & 18.5 & 75 & 5.3 & .24 & 14 & 3.8 & $<.1$ & 73 \\
\hline $2-27-90$ & .063 & 19.5 & 118 & 4.4 & .28 & 18 & 10 & .1 & 119 \\
\hline $6-29-90$ & .057 & 25.0 & 128 & 4.3 & .37 & 16 & 9.9 & $<.1$ & 143 \\
\hline $10-02-90$ & .069 & 24.5 & 145 & 4.4 & .20 & 18 & 3.3 & $<.1$ & 135 \\
\hline
\end{tabular}

\begin{tabular}{|c|c|c|c|}
\hline $11-21-88$ & 0.129 & 23.5 & 162 \\
\hline $4-10-89$ & .003 & 25.0 & 179 \\
\hline $6-13-89$ & .025 & 24.0 & 313 \\
\hline $7-12-89$ & .017 & 26.0 & 240 \\
\hline $8-07-89$ & .063 & 28.5 & 202 \\
\hline $9-08-89$ & .013 & 27.5 & 158 \\
\hline $10-11-89$ & .433 & 23.0 & 161 \\
\hline $11-30-89$ & .090 & 15.0 & 165 \\
\hline $1-18-90$ & .127 & 17.0 & 222 \\
\hline $2-28-90$ & .33 & 15.0 & 155 \\
\hline $4-11-90$ & .051 & 20.5 & 149 \\
\hline $7-02-90$ & .045 & 25.0 & 242 \\
\hline $7-14-90$ & 10.54 & -- & 120 \\
\hline $8-08-90$ & .297 & 26.0 & 320 \\
\hline $10-03-90$ & .063 & 30.5 & 301 \\
\hline
\end{tabular}

Grace Creek (unmined) basin

$\begin{array}{lrrcccc}-- & 0.74 & 23 & 5.6 & 32 & 117 & - \\ -- & .48 & 15 & 8.9 & 26 & 134 & 176 \\ 7.5 & .26 & 15 & 38 & 105 & 206 & 201 \\ 7.6 & .06 & 25 & 27 & 41 & 163 & 187 \\ 7.1 & .48 & 26 & 8.1 & 35 & 148 & -- \\ 6.9 & .63 & 23 & 11 & 23 & 133 & 144 \\ 7.0 & .66 & 24 & 7.8 & 26 & 144 & 162 \\ 7.2 & .36 & 25 & 8.5 & 20 & 120 & - \\ 7.7 & .28 & 21 & 19 & 53 & 143 & 110 \\ 6.6 & .50 & 22 & 8.4 & 20 & 108 & 124 \\ 6.8 & .54 & 23 & 11 & 15 & 115 & 122 \\ 6.8 & .35 & 26 & 42 & 13 & 164 & 192 \\ -- & .55 & 16 & 17 & 5.1 & 123 & -- \\ 7.8 & .31 & 14 & 29 & 102 & 199 & 208 \\ 7.5 & .16 & 26 & 34 & 67 & 197 & 216\end{array}$

CFI-3 Creek (unmined) basin

\begin{tabular}{|c|c|c|c|c|c|c|c|c|c|c|}
\hline $11-29-88$ & 0.017 & 17.5 & 84 & -- & 0.44 & 14 & 4.8 & 5.9 & 116 & -- \\
\hline $9-06-89$ & .080 & 28.5 & 133 & 5.5 & .37 & 21 & 11 & 3.4 & 176 & 189 \\
\hline $10-20-89$ & .014 & 18.5 & 94 & 6.0 & .55 & 14 & 3.2 & 4.1 & 99 & 185 \\
\hline $11-16-89$ & -- & -- & -- & -- & .18 & 17 & 33 & 6.8 & 153 & -- \\
\hline $12-07-89$ & .001 & 14.5 & 73 & 5.9 & .33 & 15 & 5.6 & 6.2 & 90 & -- \\
\hline $1-04-90$ & -- & -- & -- & -- & .33 & 14 & 8.4 & 3.8 & 84 & -- \\
\hline $1-25-90$ & .010 & 25.0 & 70 & 6.3 & .56 & 14 & 5.1 & 5.7 & 81 & 29 \\
\hline $2-23-90$ & -- & -- & -- & -- & - & 17 & 7.3 & 2.6 & 104 & -- \\
\hline $3-08-90$ & .021 & 19.5 & 86 & 6.1 & .57 & 16 & 6.0 & 5.6 & 89 & 95 \\
\hline $8-16-90$ & .025 & 25.0 & 147 & 5.8 & .27 & 16 & 23 & 5.9 & 156 & 184 \\
\hline $10-10-90$ & .090 & 27.5 & 115 & 5.8 & .46 & 16 & 1.7 & 3.4 & 128 & 178 \\
\hline \multicolumn{11}{|c|}{ Mobil Creek (reclaimed clay-settling) basin } \\
\hline $9-05-89$ & 0.025 & 26.0 & 60 & 6.7 & 2.5 & 4.2 & 8.8 & 18 & 122 & -. \\
\hline $10-17-89$ & -- & -- & -- & -- & 2.4 & 3.5 & 8.0 & 31 & 113 & 155 \\
\hline \multicolumn{11}{|c|}{ Agrico-9 Creek (reclaimed clay-settling) basin } \\
\hline $6-26-90$ & 1.07 & 28.5 & 382 & 7.6 & 0.51 & 13 & 49 & 98 & 219 & 241 \\
\hline $7-19-90$ & 1.54 & -- & -- & -- & .99 & 5.9 & 76 & 139 & 294 & -- \\
\hline
\end{tabular}


Table 10. Physical and chemical characteristics of water from streams in the study basins--bimonthly samples--Continued

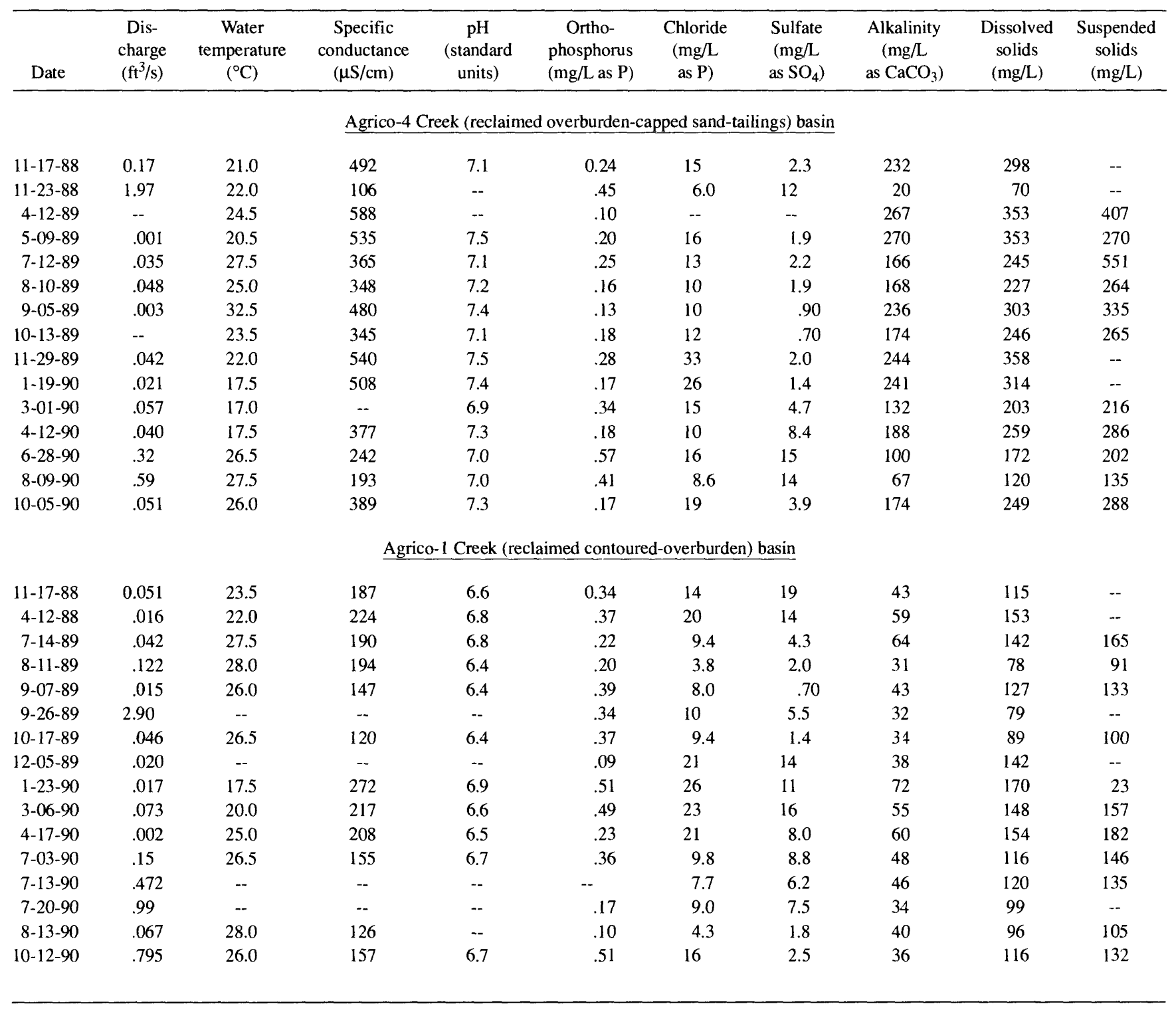

in surface water ranged from 23 to $910 \mu \mathrm{g} / \mathrm{L}$ at the unmined basins and from 35 to $170 \mu \mathrm{g} / \mathrm{L}$ at the reclaimed basins, less than the 1.0-mg/L FDER Class III surface-water standard.

The chemical composition of water from streams in the six study basins sampled bimonthly are shown in figure 63 . The composition of the surface-water samples collected at the three unmined basins are similar. Surface water in the unmined basins was predominantly a calcium chloride or sodium chloride water. Magnesium bicarbonate or calcium bicarbonate were the major dissolved ions in water from streams at the reclaimed basins. The chemical composition of surface-water samples collected during base flow was similar to the composition of water from the surficial aquifer system within each basin.

\section{Trace Elements}

Concentrations of the trace elements cobalt, copper, lead, manganese, molybdenum, nickel, arsenic, beryllium, and cadmium in water from streams in the study basins were equal to or less than the analytical detection limits (table 9). Silver, however, was detected in concentrations of $2.0 \mu \mathrm{g} / \mathrm{L}$ in 


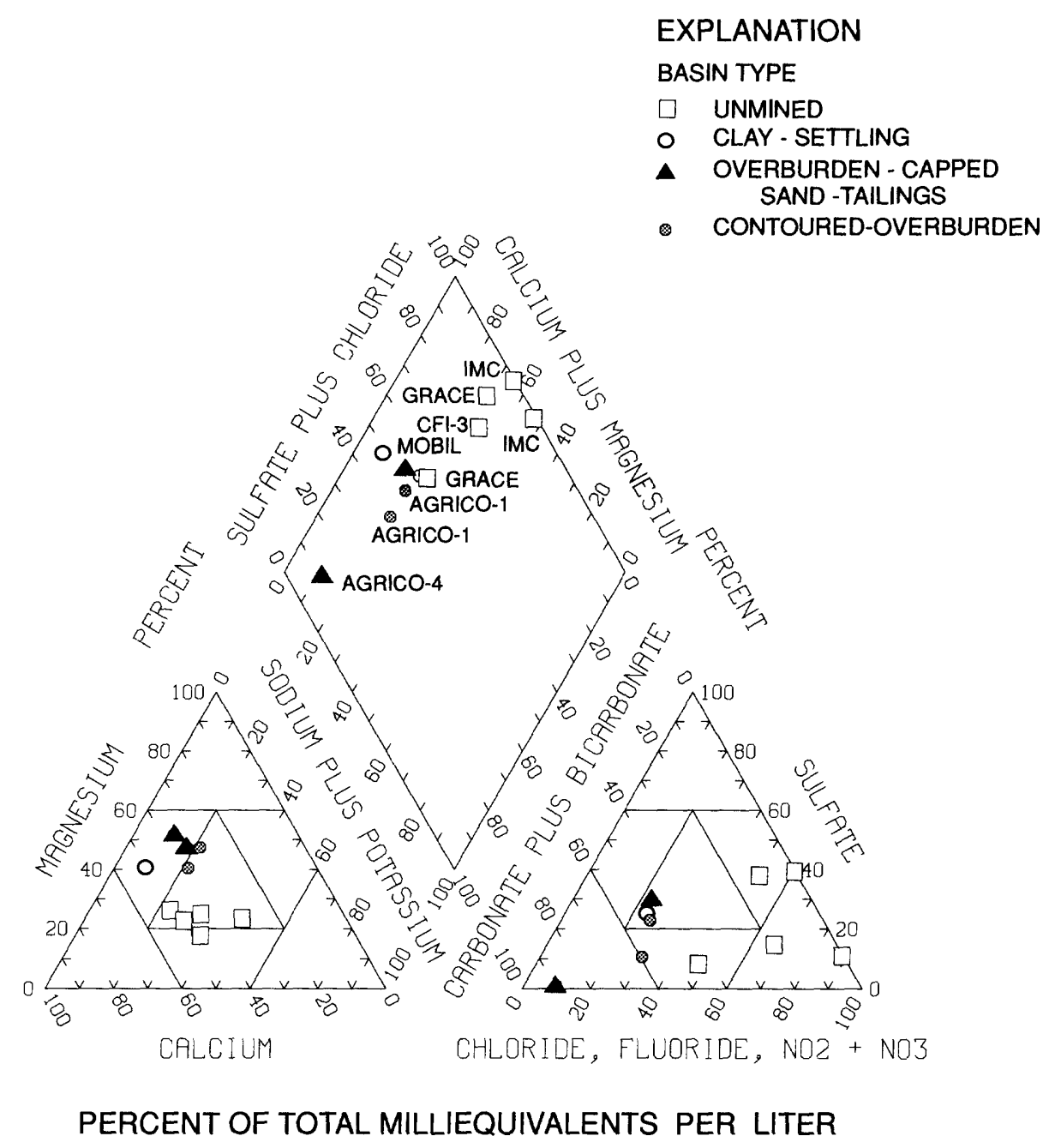

Figure 63. Chemical composition of water from streams in the study basins.

surface-water samples from the Grace Creek and Mobil Creek basins. This concentration exceeded the $0.07-\mu \mathrm{g} / \mathrm{L}$ FDER class III surface-water standard for silver. Mercury concentrations were less than the detection limit of $0.1 \mu \mathrm{g} / \mathrm{L}$ in samples from the reclaimed basins, but were as high as $0.6 \mu \mathrm{g} / \mathrm{L}$ in samples from the unmined basins, and exceeded the 0.012$\mu \mathrm{g} / \mathrm{L}$ FDER class III surface-water standards. Barium concentrations were relatively low in surface-water samples from all of the study basins, ranging from less than 2 to $15 \mu \mathrm{g} / \mathrm{L}$. Barium concentrations were well below the 1-mg/L FDER class I surface-water standard. Concentrations of boron and zinc in water samples from streams at all study basins were less than $30 \mu \mathrm{g} / \mathrm{L}$. Lithium concentrations were less than the $4-\mu \mathrm{g} / \mathrm{L}$ detection level in samples from all basins, except the reclaimed Agrico-9 Creek and Agrico-4 Creek basins. Lithium concentrations in samples collected from these basins during high-flow conditions were less than 6 and $23 \mu \mathrm{g} / \mathrm{L}$, respectively. Vanadium concentrations were $10 \mu \mathrm{g} / \mathrm{L}$ or less (detection limit, $6 \mu \mathrm{g} / \mathrm{L}$ ) in all surface water samples. Iodide concentrations were determined for only three surface-water samples, two from the IMC Creek basin and one from the Agrico-4 Creek basin. Iodide concentrations in these samples ranged from 0.013 to $0.028 \mathrm{mg} / \mathrm{L}$.

\section{Radiochemicals}

Gross-alpha activity levels in water samples from streams in the study basins ranged from 0.34 to $3.54 \mathrm{pCi} / \mathrm{L}$ in the unmined basins and from 0.34 to $10.2 \mathrm{pCi} / \mathrm{L}$ in the reclaimed basins, but were less than the FDER surface-water standard of $15 \mathrm{pCi} / \mathrm{L}$ at all basins (table 9). Gross-beta activity as Cs-137 ranged from 1.7 to $7.5 \mathrm{pCi} / \mathrm{L}$ at the unmined basins and from 0.9 to $13 \mathrm{pCi} / \mathrm{L}$ at the reclaimed basins. Activity levels of radium-226 were low in surface-water samples at all of the study basins, less than the FDER surface-water standard of $5 \mathrm{pCi} / \mathrm{L}$. Radium-226 activity levels at the unmined IMC Creek basin were slightly higher during base-flow conditions than during high-flow conditions. Polonium-210 activity 
levels in water samples collected from streams at the unmined and at the reclaimed basins were less than the detection limit of $1.0 \mathrm{pCi} / \mathrm{L}$. Uranium-238 levels were at or less than the detection limit of $0.1 \mathrm{pCi} / \mathrm{L}$ at all the study basins, except at Mobil Creek basin, where the uranium-238 activity level was $0.60 \mathrm{pCi} / \mathrm{L}$, and at Agrico-4 Creek basin, where the base-flow sample had an activity of $0.20 \mathrm{pCi} / \mathrm{L}$. Results of the analyses for uranium-234 in surface-water samples indicated that levels generally were low throughout the study basins and ranged from less than the detection limit of 0.1 to $0.2 \mathrm{pCi} / \mathrm{L}$, except at the reclaimed clay-settling basins. Uranium-234 activities in samples from streams in the reclaimed claysettling basins were $0.7 \mathrm{pCi} / \mathrm{L}$ for the Mobil Creek basin and $4.3 \mathrm{pCi} / \mathrm{L}$ for the Agrico-9 Creek basin. These higher values are attributed to the radioactivity levels associated with the clay deposited in these basins during reclamation. Miller and Sutcliffe (1983) reported gross-alpha activities of $1,460 \mathrm{pCi} / \mathrm{L}$ and gross-beta activities of $3,480 \mathrm{pCi} / \mathrm{L}$ for a clay slurry pumped into a clay-settling area. However, they reported relatively low activity levels in drainage from the area after the clays had settled. Thus, clay-settling areas trap radioactive materials associated with the clay, but seem to release small amounts of the radioactive materials to surface runoff from the basin.

\section{SUMMARY AND CONCLUSIONS}

Hydrologic and water-quality characteristics of eight small rural basins in the phosphate-mining region of westcentral Florida were evaluated and compared. Three unmined basins, IMC Creek, Grace Creek, and CFI-3 Creek, represent background hydrologic conditions and water-quality characteristics that occur naturally in the region. Five reclaimed basins, Mobil Creek, Agrico-9 Creek, CFI-1 Creek, Agrico-4 Creek, and Agrico-1 Creek, represent previously mined basins that have been reclaimed using four different reclamation methods commonly used by the phosphate industry.

Data collection at each basin included operation of a streamflow-gaging station, a rainfall-recording gage, continuous water-level recorders at wells open to the surficial and intermediate aquifer systems, and periodic measurement of water levels in 10 to 13 shallow observation wells.

Reconnaissance water-quality sampling was done at the beginning of the study to determine concentrations of major ions, trace elements, nutrients, and radiochemicals in water from the surficial aquifer system and from streams at each basin. In addition, water samples were collected bimonthly from streams and from wells completed in the surficial and intermediate aquifer systems in each basin for analysis of alkalinity, pH, chloride, sulfate, specific conductance, orthophosphorus, and dissolved solids. Suspended solids were also analyzed in selected samples collected during base-flow and high-flow conditions.

The data-collection period at most sites was from October 1988 to September 1990. Rainfall totals measured at the National Weather Service rain gage at Wauchula during the study were less than the 30 -year average annual rainfall of 53 in. Rainfall totaled 51 in. in 1988, 40 in. in 1989, and 46 in. in 1990. The below normal rainfall resulted in relatively low runoff and ground-water levels during the study.

The depth to the water table in the surficial aquifer system ranged from 0.10 to $4.77 \mathrm{ft}$ below land surface at the unmined basins and at the basins reclaimed using native overburden or overburden-capped sand-tailings (Agrico-1 Creek and Agrico-4 Creek basins). The depth to the water table at the basins reclaimed by backfilling mined areas with clay or sand and clay wastes from ore processing (Mobil Creek, Agrico-9 Creek, and CFI-1 Creek basins) was greater than that at the unmined basins and at the other two reclaimed basins. Depths to the water table in these basins ranged from 3.9 to $13.4 \mathrm{ft}$ below land surface.

Water generally discharges from the surficial aquifer system to streams at the unmined basins and at the reclaimed Agrico-4 Creek and Agrico-1 Creek basins. Little or no ground water flows to streams in the reclaimed Mobil Creek, Agrico-9 Creek, and CFI-1 Creek basins because the water table generally is below the stream channel and because the permeability of the surficial deposits, which contain significant amounts of clay wastes from ore processing, is low.

Hydraulic conductivity of the surficial aquifer system at the unmined basins ranged from 0.1 to $17.9 \mathrm{ft} / \mathrm{d}$. The hydraulic conductivity of the surficial aquifer system at the reclaimed basins varied depending on the type of fill material used during reclamation. The clay-settling basins, Mobil Creek and Agrico-9 Creek, had low hydraulic conductivities of $1.2 \mathrm{ft} / \mathrm{d}$ or less. The surficial aquifer system at the reclaimed Agrico-4 Creek basin had the highest hydraulic conductivity of any of the basins. A hydraulic conductivity of $57.8 \mathrm{ft} / \mathrm{d}$ was calculated at a well screened in highly permeable, washed sand waste from the ore-processing operations

Discharges of streams in the eight study basins ranged from 0 to $63 \mathrm{ft}^{3} / \mathrm{s}$ at the three unmined basins, IMC Creek, Grace Creek, and CFI-3 Creek, and from 0 to $88 \mathrm{ft}^{3} / \mathrm{s}$ at the reclaimed basins. The highest runoff per square mile for any of the basins was $500\left(\mathrm{ft}^{3} / \mathrm{s}\right) / \mathrm{mi}^{2}$ at the reclaimed Mobil Creek basin. Peak discharges generally were higher at the reclaimed basins during intense, short-duration thunderstorms, but were similar at both the unmined and reclaimed basins during low-intensity, long-duration frontal storms.

Except for the Mobil Creek basin, streamflows generally responded more slowly to rainfall at the reclaimed basins than at the unmined basins because of surface storage and less developed drainage networks in the reclaimed basins. At the Mobil Creek basin, runoff responded rapidly to rainfall because the basin has been reclaimed with an impervious clay fill and has a relatively steep slope and small drainage area.

Analyses of water samples from the surficial aquifer system indicated that ground water from the reclaimed basins generally had higher concentrations of most constituents than did ground water from the unmined basins. Concentra- 
tions of most constituents, however, were within the State water-quality guidelines established by the Florida Department of Environmental Regulation (FDER). Color and concentrations of dissolved solids, sulfate, iron, manganese, and lead exceeded the water-quality guidelines in some water samples from the surficial aquifer system in several of the reclaimed basins, and iron concentrations and gross-alpha activities exceeded guidelines in ground water at some of the unmined sites. Elevated ammonia concentrations in water from this aquifer system at reclaimed basins Agrico-4 Creek and CFI-1 Creek (17.4 and 7.0, mg/L, respectively) significantly exceeded concentrations in the unmined basins.

Results of radiochemical analyses of water samples from the surficial aquifer system at the reclaimed basins indicated that radiochemical activities were within the range specified in FDER drinking water standards. Gross-alpha and gross-beta activities at the unmined basins were noticeably higher than activities at the reclaimed basins. The unmined Grace Creek and CFI-3 Creek basins had grossalpha activities of 53 and $37.4 \mathrm{pCi} / \mathrm{L}$, respectively. The elevated gross-alpha activities at these unmined basins are attributed to the near-surface deposits of phosphate ore in the area of the wells sampled. The gross-alpha and gross-beta activities in water from the surficial aquifer system at the reclaimed basins were less than $6 \mathrm{pCi} / \mathrm{L}$. A gross-beta activity of $10 \mathrm{pCi} / \mathrm{L}$ was measured in ground-water samples from the unmined Grace Creek basin.

Water from the intermediate aquifer system generally had slightly higher specific conductance values, alkalinities, and dissolved-solids concentrations at the reclaimed basins than at the unmined basins. Concentrations of most constituents, however, met FDER drinking water standards.

Analyses of water samples collected from streams during base-flow and high-flow conditions indicated that the water chemistry of surface waters in the unmined and the reclaimed basins generally was similar. Higher concentrations of magnesium, orthophosphorus, alkalinity, and calcium were detected in water samples from streams at some of the reclaimed basins. Radiochemical analyses of surface-water samples from the two clay-settling basins, Mobil Creek and Agrico-9 Creek, indicated uranium-234 activities of 0.7 and $4.3 \mathrm{pCi} / \mathrm{L}$, respectively.

The nydrologic characteristics and surface- and ground-water quality of the Agrico-4 Creek and Agrico-1 Creek basins, which were reclaimed by redistributing overburden spoil material (overburden-capped sand-tailings and contoured-overburden), were similar to those of the unmined basins. The hydrologic characteristics and surface- and ground-water quality of the Mobil Creek, Agrico-9 Creek, and CFI- 1 Creek basins, which were reclaimed using the clay or sand and clay fraction of the phosphate-matrix (claysettling and sand-clay settling), differed, somewhat from those of the unmined basins. The major observed differences are reduced runoff due to surface storage and increased uranium-234 activity at the recently reclaimed clay-settling basin (Agrico-9 Creek) and more rapid runoff response to rainfall, reduced flow, greater depths to the water table, and a more gradual water-table response to recharge at the established clay-settling basin (Mobil Creek).

\section{SELECTED REFERENCES}

Atkins, K., 1981, Biotic response to drawdown and reflooding in a clay settling pond, in Stovall, R.H., ed., Wetland Restoration and Creation Conference, Tampa, Fla., 1981 [Proceedings] p. 169-187.

Barr, G.L., 1989, Potentiometric surface of the intermediate aquifer system, west-central Florida, September 1988: U.S. Geological Survey Open-File Report 89-36, 1 sheet.

Bill, J.F., and Reeves, M.J., 1982, Mines: A model to forecast mine wastewater quality: International Journal of Environmental Studies, v. 20, p. 47-52.

Bouwer, Herman, 1989, The Bouwer and Rice slug test-an update: Ground Water, v. 27, p. 304-309.

Bouwer, Herman, and Rice, R.C., 1976, A slug test for determining hydraulic conductivity of unconfined aquifers with completely or partially penetrating wells: Water Resources Research, v. 12, no. 3, p. 423-428.

Bryan, B.A., and Hewlette, J.D., 1981, Effect of surface mining on storm flow and peak flow from six small basins in Kentucky: Water Resources Bulletin, v. 17, no. 2, p. 290-299.

Buono, Anthony, and Rutledge, A.T., 1979, Configuration of the top of the Floridan aquifer, Southwest Florida Water Management District and adjacent areas: U.S. Geological Survey Water-Resources Investigations Open-File Report 78-34, 1 sheet.

Buono, Anthony, Spechler, R.M., Barr, G.L., and Wolansky, R.M., 1979, Generalized thickness of the confining bed overlying the Floridan aquifer, Southwest Florida Water Management District: U.S. Geological Survey Water-Resources Investigations Open-File Report 79-1171, 1 sheet.

Curtis, W.R., 1979, Surface mining and the hydrologic balance: Mining Congress Journal, v. 65, no. 7, p. 35-40.

Dames and Moore, Inc., 1983, A survey of wetland reclamation projects in the Florida phosphate industry: Consultant's report prepared for and in the files of the Florida Institute of Phosphate Research, 64 p.

Deely, D., 1977, Water quality management guidance for mine-related pollution sources: U.S. Environmental Protection Agency, Water Quality Management Program EPA-440/3-77-027, p. 4-44.

Duerr, A.D., Hunn, J.D., Lewelling, B.R., and Trommer, J.T., 1987, Geohydrology and 1985 water withdrawals of the aquifer systems in southwest Florida, with emphasis on the intermediate aquifer system: U.S. Geological Survey Water-Resources Investigations Report 87-4259, 115 p.

Florida Department of Environmental Regulation, 1992, Water quality standards: Chapter 17-3, in Florida Administrative Code.

Garlanger, J.E. and Fuleihan, N. F, 1983, Reclamation options for clay settling areas, in Symposium on Reclamation and the Phosphate Industry, Clearwater Beach, Florida, [Proceedings] Ardaman and Associates, Inc., p. 31-58. 
Gilbert, T., King, T., Barnett, B., Allen, J.N., Jr., and Hearon R.S., 1979, Wetlands reclamation technology development and demonstration for Florida phosphate mining, in Cole, D.P., ed., Conference on Wetlands Restoration and Creation, Tampa, Fla., 1980 [Proceedings] p. 87-101.

Gilbert, T., King, T., Hord, L., and Allen, J.N., Jr., 1980, Assessment of wetlands establishment techniques at a Florida phosphate mine site, in Cole, D.P., ed., Conference on Wetland Restoration and Creation, Tampa, Fla., 1980 [Proceedings] p. 245-263.

Haan, C.T., and Barfield, B.J., 1978, Hydrology and sedimentology of surface-mined lands: Lexington, University of Kentucky, Office of Continuing Education and Extension College of Engineering, p. 286.

Hem, J.D., 1989, Study and interpretation of the chemical characteristics of natural water: U.S. Geological Survey Water-Supply Paper 2254, 263 p.

Hunn, J.D., and Seaber, P.R., 1986, Effects on ground-water quality of seepage from a phosphatic clayey waste settling pond, north-central Florida: U.S. Geological Survey Water-Resources Investigations Report 86-4107, 57 p.

Hutchinson, C.B., 1978, Appraisal of shallow ground-water resources and management alternatives in the upper Peace and eastern Alafia River basins, Florida: U.S. Geological Survey Water-Resources Investigations 77-124, 57 p.

___ 1991, Assessment of hydrogeologic conditions with emphasis on water quality and wastewater injection, southwest Sarasota and west Charlotte Counties, Florida: U.S. Geological Survey Open-File Report 90-709.

Keen, P.W., and Sampson, J.G., 1983, The sand/clay mix technique: A method of clay disposal and reclamation options, in Symposium on Reclamation and the Phosphate Industry, Clearwater Beach, Fla., [Proceedings], p. 59-84.

King, T., Hord, L., Gilbert, T., Montalbano, F., III, and Allen, J.N., Jr., 1980, An evaluation of wetland habitat establishment and wildlife utilization in phosphate clay settling ponds, in Cole, D.P., ed., Wetland Restoration and Creation Conference, Tampa, Fla., 1980 [Proceedings] p. 35-49.

Koch, Donald, 1986, Analytical modeling of ground-water impacts by mining: Ground Water, v. 24, no.2, p. 224-230.

Lewelling, B.R., 1989, Potentiometric surface of the intermediate aquifer system, west-central Florida, May 1988: U.S. Geological Survey Open-File Report 88-721, 1 sheet.

Long, H.W., Jr., and Orne, D.P., 1990, Regional study of land use planning and reclamation: Central Florida Planning Council, p. 77.

Martin, J.D., Crawford, C.G., Duwelius, R.F., and Renn, D.E., 1990, Description of the physical environment and coal-mining history of west-central Indiana, with emphasis on six small basins: U.S. Geological Survey Water-Supply Paper 2368-A, $38 \mathrm{p}$.

Martin, J.D., Duwelius, R.F., and Crawford, C.G., 1990, Effects of surface coal mining and reclamation on the geohydrology of six small basins in west-central Indiana: U.S. Geological Survey Water-Supply Paper 2368-B, 71 p.

Miller, J.A., 1986, Hydrogeologic framework of the Floridan aquifer system in Florida and in parts of Georgia, South Carolina, and Alabama: U.S. Geological Survey Professional Paper 1403-B, $91 \mathrm{p}$.
Miller, J.A., Hughes, G.H., Hull R.W., Vecchioli, John, and Seaber, P.R., 1978, Impact of potential phosphate mining on the hydrology of Osceola National Forest, Florida: U.S. Geological Survey Water-Resources Investigations 78-6, 159 p.

Miller, R.L., and Sutcliffe, Horace, Jr., 1982, Water-quality and hydrogeologic data from three phosphate industry waste-disposal sites in central Florida, 1979-1980: U.S. Geological Survey Water-Resources Investigations 81-84, $184 \mathrm{p}$.

1983, Effects of three phosphate sites on ground-water quality in central Florida, 1979-1980: U.S. Geological Survey Water-Resources Investigations Report 83-4256, 184 p.

National Oceanic and Atmospheric Administration, 1988, Climatological data annual summary, Florida: v. 92, no. 12, $34 \mathrm{p}$.

1989, Climatological data annual summary, Florida: v. 93, no. $13,34 \mathrm{p}$.

1990, Climatological data annual summary, Florida: v. 94, no. $14,34 \mathrm{p}$.

Osterkamp, W.R., and Hedman, E.R., 1979, Discharge estimates in surface mine areas using channel geometry techniques, in Surface Mining Hydrology, Sedimentology, and Reclamation Symposium, Lexington, Ky., 1979 [Proceedings], p. 43-49.

Robertson, A.F., 1973, Hydrologic conditions in the Lakeland Ridge area of Polk County, Florida: Florida Bureau of Geology Report of Investigations no. 64, 54 p.

Rogowski, A.S., and Jacoby, E.L., Jr., 1979, Monitoring water movement through strip mine profiles: Transactions of the American Society of Agricultural Engineers, v. 22, no. 1, p. 104-109 and 114.

Rogowski, A.S., and Weinrich, B.E., 1981, Modeling water flux on strip-mined land: American Society of Agricultural Engineers Paper 77-2061.

Rouse, H., 1950, Engineering hydraulics: Iowa Institute of Hydraulic Research, p. 289-320.

Ryder, P.D., 1985, Hydrology of the Floridan aquifer system in west-central Florida: U.S. Geological Survey Professional Paper 1403-F, $63 \mathrm{p}$.

Sandburg, R., Scheibach, R., Koch, D., and Prickett, T., 1981, Selected hand-held calculator codes for the evaluation of the probable cumulative hydrologic impacts of mining: Denver, Colo., Hittman Associates Report H-D3004/030-81-1029 F, prepared for and on file at the Office of Surface Mining, Region 5.

Saunders, G.P., 1983, Aquifer dewatering and drawdown at an open mine pit in northeastern Colorado: Ground Water Monitoring Review, v. 3, no. 1, p. 122-126.

Scott, T. M., 1988, The lithostratigraphy of the Hawthorn Group (Miocene) of Florida: Florida Geological Survey Bulletin no. 59,148 p.

Shown, L.M., Frickel, D.G., Miller, R.F., and Bronson, F.A., 1982, Methodology for hydrologic evaluation of a potential surface mine: Loblolly Branch Basin, Tuscaloosa County, Alabama: U.S. Geological Survey Water-Resources Investigations Report 82-50, 93 p.

Skougstad, M.W., Fishman, M. J., Friedman, L.C., Erdmann, D.E., and Duncan, S.S., eds., 1979, Method for determining inorganic substances in water and fluvial sediments: U.S. Geological Survey Techniques of Water Resources Investigations, book 5, chap. $\mathrm{Al}, 626 \mathrm{p}$. 
Southeastern Geological Society, 1988, Hydrogeological units of Florida: Florida Geological Survey Special Publication 28, 9 p.

Stewart, H.G., Jr., 1966, Ground-water resources of Polk County, Florida: Florida Geological Survey Report of Investigations no. $44,170 \mathrm{p}$.

Swancar, Amy, and Hutchinson, C.B., 1992, Chemical and isotopic composition and potential for contamination of the Upper Floridan aquifer, west-central Florida, 1986-89: U.S. Geological Survey Open-File Report 92-47, 47 p.

U.S. Department of Agriculture, 1990, Soil Conservation Service, Soil survey of Polk County, Florida, $235 \mathrm{p}$.

U.S. Environmental Protection Agency, 1973, Processes, procedures, and methods to control pollution from mining activities: Office of Water Program Operation, EPA-430/9-73-011.

U.S. Fish and Wildlife Service, 1980, Reclaiming Florida phosphate mined lands to wetlands: U.S. Department of the Interior, Biological Services Program FWS/OBS-80/492, $13 \mathrm{p}$.
Vecchioli, John, Tibbals, C.H., Duerr, A.D., and Hutchinson, C.B., 1990, Ground-water recharge in Florida-a pilot study in Okaloosa, Pasco, and Volusia Counties: U.S. Geological Survey Water-Resources Investigations Report 90-4195, 16 p.

Ward, J.R., and Harr, C.A., 1990, Methods for collecting and processing of surface-water and bed-material samples for physical and chemical analyses: U.S. Geological Survey Open-File Report 90-140, 71 p.

White, W.A., 1970, The geomorphology of the Florida peninsula: Florida Bureau of Geology Bulletin 51, 164 p.

Wilson, W.E., and Gerhart, J.M., 1977, Simulated effects of ground-water development on the potentiometric surface of the Floridan aquifer, west-central Florida: U.S. Geological Survey Open-File Report 79-1271, 119 p.

Wolansky, R.M., 1983, Hydrogeology of the Sarasota-Port Charlotte area, Florida: U.S. Geological Survey Water-Resources Investigations Report 82-4089, 48 p. 
